\title{
تطبيق القانون الأجنبى أهماه القضاء الجنائى
}

\author{
shel \\ د. أكمل يوسف السعيد يوسف \\ مدرس القانون الجنائى \\ كليت الحقوق - جامعت المنصورة
}




\section{تمبهمبـ:}

إذا كانـت القاعدة العامـة أن القاضـي الـوطني ابتـداء لا يمكنـه أن يطبق سـوي

قانونه الوطني، سواء العقابي أو غير العقابي، إلا أنه استثناء من ذلتك فإن المشرع قد يضع بعض القواعد والأصول والأحكام للقاضـي الوطني، لتمكنهـ من تطبيق القوانين الجنائية الأجنبية. وفي هذه الحالة فإن القاضسي الوطني سيكون ملزماً بإتباع الخطة التشريعية الوطنية في ذلك. كما هو الحال في قواعد الإسناد والإحالة في القانون الدولي الخاص، عند تطبيق القواعد القانونية غير العقابية، حيث قد يتوقف الفصل في النزاع المعروض على القاضــي الجنـائي الـوطني على ضـرورة الرجـوع للقـانون الأجنبـي. والقاضي الوطني ملزم في ذلك باستخدام كافة الوسـائل للعلم بأحكام القـانون الأجنبي، وطرق إثباته وتفسيره.

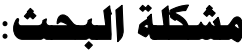

إن العقبة الحقيقية التي تعترض تطبيق القانون الجنائي الأجنبي ليست الصعوبة التي قد يلاقيها القاضي الوطني في الإلمسام بأحكامـه، فالوضع لا يختلف عمـا هو مقرر في المواد غير الجنائية حيث يطبق القاضسي قوانين أجنبية متنوعة، ولكن العقبة هي اختلاف الأساسي بين القوانين الجنائية من حيث أنواع العقوبـات التي تقررهـا وأنواع السجون والمؤسسات العقابية التي تعترف بها، الأمر الذي قد يجعل بعض العقوبـات التي يقرهـا القانون الأجنبي غير صـالحة للتطبيق بـالنظر إلى عدم وجود المؤسسات العقابية المخصصة لها. وبالإضافة إلى ذلتك فالدولـة تستهرف بالعقـاب حمايـة المجتمع من وجهة نظرهـا، فِان عاقبت على جريمـة ارتكبت في إقليمها فهدفها إقرار النظام والأمن فيـه، وإن عاقبت على جريمـة ارتكبت في الخـارج فهدفها حمايـة مصالح لها، ويفسر ذلك الحرص على تطبيق القانون الإقليمي باعتباره وحده الأي يعبر عن وجهة 
نظر الدولة. وعلى هذا النحو، يتضح فساد القول بأن القانون الطبيعي لجريمـة ارتكبت في الخـارج هو القانون الساري في الإقليم الذي ارتكبت فيه، فبإذا ثبت أن الدولـة لا تعاقب على هذه الجريمة لأنها أهدرت هذا القانون ولكن لأنها أهدرت بعض مصالحها، فلا محل للثك في أن القانون الطبيعي لها هو قانون القاضي. ونأمل أن ينتصر الاتجاه الذي يظلب تطبيق القوانين الجنائية الأجنبية، أسوة بما هو متبع في القانون الدولي الخـاص، نظراً لأن تطبيق القوانين الجنائية الأجنبية يعد أسهل وأيسر من تطبيق القوانين المدنية، لقلة عددها، وسهولة حصرها، مما يجعل أمر معرفتها والتوصل إليها أمراً سـهلاً وميسوراً، ولا تتتج مشاكل كثيرة على تطبيقها، بخلاف القوانين الأخرى غير الجنائية التي دائما ما تكون متعددة ومتداخلة مـع بعضها البعض، بل أن القاضي الوطني قد يقع في حرج شديد عند تطبيقها أكثر من الحرج الذي يقابله، عند تطبيقه للقوانين الجنائية، فتحديدها على وجه الدقة يجعل من الصعوبة بمكان إثارة المشاكل المتشعبة عن ذلك التطبيق.

خطة البمث:

\section{الفصل الأول: هركز القانون الأجنبي أهام القضاء الجنائي.}

المبحث الأول: الجدل الفقهي حول تطبيق القاضـي الجنـائي لقـانون العقوبـات

$$
\text { الأجنبي. }
$$

المبحث الثاني: الأساس القانوني لتطبيق القاضي الجنائي للقانون الأجنبي.

المبحث الثالث: صور تطبيق القاضي الجنائي للقانون الأجنبي.

المبحث الرابع: دور القاضي الجنائي في تحديد مضمون القانون الأجنبي. 
الفصل الثاني: تطبيق القاضي الجنائي للقانون الجنائي الأجنبي.

$$
\text { المبحث الأول: الأخذ في الاعتبار القانون الجنائي الأجنبي. }
$$

المبحث الثاني: الأخذ في الاعتبار الأحكام الجنائية الأجنبية.

المبحث الثالث:طبيعة المحررات الرسمية الأجنبية.

المبحث الرابع: الأحكام الجنائية الأجنبية في القانون الأمريكي. 


\section{الفصل الأول}

\section{هركز القانون الأجنبي أهام القضاء الجنائي}

سوف نعرض في هذا الفصل لبيان مركز القانون الأجنبي أمام القضاء الجنـائي، وسـنعرض في المبحث الأول للجـل الفقهـي حـول تطبيـق القاضــي الجنـائي لقـانون العقوبات الأجنبي، ثم نبين في المبحث الثاني الأساس القانوني لتطبيق القاضي الجنائي للقانون الأجنبي، ثم نبين في المبحث الثالث صور تطبيق القاضسي الجنائي للقانون الأجنبي، وأخيرا نبين دور القاضي الجنائي في تحديد مضمون القانون الأجنبي.

\section{المبحث الأول}

\section{الجدل الفقهي حول تطبيق القاضي الجنائي للقانون الأجنبي}

يؤمن بعض الفقهـ بحق القاضـي الوطني في تطبيق قانون جنـائي أجنبي، إلى جاتب الاعتراف بحقه في تطبيق قانونه الوطني تجنبا لجمود القانون وعجزه عن حماية مصالح الدولة التي يلحقها أضرار جسيمة خـارج اقليمها فضلا عن القيام بمطاردة الجاني أو محاكمته إذا لم يطبق قانون محل ارتكـاب الفعل الإجرامس، خاصـة مـع عجز المبادئ العامة في تحديد الاختصاص الجنائي الدولي عن ملاحقة الجناة('). 
فالهروب من توقيع الجزاء المناسب طبقا للقانون الوطني لمحل ارتكاب الواقعة يفرض ضرورة التعاون الاولي لمواجهة سهولة ارتكاب الجرائم ذات العنصر الأجنبي، بل إن الدولة قد تجد نفسها عاجزة عن اتخاذ أي إجراء حيال الجناة، إذا ما لجأوا لدولنة مـوطنهم الأصلي والذي يتعارض مـع مبدأ عدم جواز تسليم الرعايـا الوطنيين لدولـة أجنية. إلا أن الاتفاقية الاسكندنافية الخاصة بتسليم المجرمين، أجازت تسليم الوطنيين لاولة أخرى من تلكك الدول الموقعة على الاتفاقية، ولكن تشترط هذه الدول ألا يكون الفعل المطلوب بسببه التسليم، قد وقع كاملا على إقليم الدولـة المطلوب منها التسليم، كذلك فإن الدولة المطلوب منها التسليم يمكن أن ترفضه، إذا كانت الجريمـة المطلوب بسبها التسليم من الجرائم الخطرة، والتي تمس بالدرجـة الأولـي مصالح تلك الدولـة

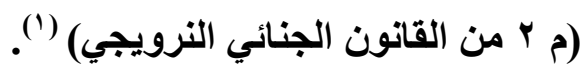

لـلكا يمكن تطبيـق مبـدأ الإقليميـة بشكل غير مباشـر عبر إخضاع الجريمـة لقانونها الطبيعي الذي يعد أقدر القوانين لافع الخطر الناشئ عنها، وذلك بتطبيق قانون محل ارتكاب الفعل الآثم بمعرفة أي دولة تقبض على الجاني تحقيقـا لفكرة المصلحة العامـة الدولية عبر تجنب افلات المجرمين من العقاب، ويمكن تسمية ذلك بالامتداد الاقليمي الخاص بالقانون الأجنبي().

(1) د/ حازم مختار الحارونى، نطاق تطبيق القاضي الجنائي للقانون الجنائي، رسالة دكتوراه، حقوق

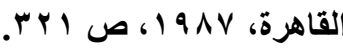

(2) LAINE, A. : Considerations sur l'execution forcee des jugements etrangers en France, in R.C.L. J. 1902, PP. 626 et. ss. 
إلا أن غيـاب الإلزام والإجبـار يجعل خضوع القاضسي الوطني للقـانون الأجنبي للفصل في الخصومة بمثابـة استشارة لـه فقط دون الركون لفكرة المـصلحة العامـة الدولية كأساس لتطبيق القانون الأجنبي. وعلي جانب آخر ذهب اتجـاه فقهي إلى أن أساس تطبيق القاضي الوطني للقانون الأجنبي هو الأثر المترتب على التزام القاضي الـوطني بـالقوانين الوطنيـة مسن خـلال الـولاء للسيادة الأجنبيـة التي تحكم الخصومة وتحقق المصلحة العليا للاولـة لقدرة القـانون الأجنبي الحساكم للعلاقة القانونيـة علي الفصل فيها مقارنة بالقانون الوطني ('). ونخلص ممـا سـبق إلـي أنـه احترامـا للسيادة الإقليمية ووفقا لقواعد الإسـناد والإحالـة وامتثـالا لأوامـر المـشرع الـوطني بـدافع مـن الاحتـرام المتبـادل بـين الـدول والثعور العام باحترام العدالة العالميـة ـ حسن سير العدالة وتحقيق المنفعة الأفضل لحكم العلاقة القانونيـة يطبق القاضسي الوطني القانون الأجنبي بنـاء على النصوص الصريحة أو الضمنية في قانونـه الخـاص(؟) فتوحيد الاختصاص في العقاب علي كل اعتداء يقع علي المصالح المشتركة لمختلف الدول تفرضه عدم كفاية القوانين الوطنية في مواجهة الجريمة ذات العنصر الأجنبي.

كما أن تطبيق قانون محل ارتكاب الفعل الإجرامي يعد ضمانة أساسية وجوهرية للحرية الفردية للمذنب، حيث يحقق ذلك التطبيق مبدأين أساسيين في القانون الجنـائي وهما مبدأ شرعية الجرائم والعقوبات ـ استحالة العلم بالقانون الحاكم للواقعة إذا حدد

(1) PILlet ET NiBOyet, Manuel de droit international privé, Paris, 1924, P. 362 .

(2) PILlet ET NiBOyet, Manuel de droit international privé, Paris, 1924, P. 362 . 
الاختصاص القضائي الاختصاص التشريعي - ومبدأ عدم رجعية القوانين الجنائية، كمـا أن تطبيق قانون محل ارتكاب الفعل الإجرامي سيتجنب حالات تسليم المجرمين، والتي قد تكون مستحيلة في حالة ما إذا كان المذنب وطنياً وضبط في بلده لتعارض التسليم مع قاعدة "عدم جواز تسليم الوطنيين لدولة أجنبية"، وفي هذه الحالة سيتم محاكمته في وطنه طبقًا لقانون محل ارتكاب الفعل دون إخلال بحقوق المتهم. لذا يجب أن يكون القانون الواجب التطبيق معروفاً جيداً قبل اقتراف الجريمـة، وكذا العقوبـة التي ستوقع على الجاني حال ارتكاب فعله الآثم (').

فمـصلحة المجتمـع تقتضي أن يطبق على الجـاني قـانون محل ارتكـاب الفعل

الإجرامسي لـضمان إتمــام المحاكمـة الجنائيـة دون وجـود أي ثغرات، وأن تـتم محاكمـة الجاني مرة واحدة؛ فعدم تطبيق القاضي الوطني للقانون الأجنبي يهر ضمانتين الأولي تتمثل في إهدار مصلحة الدولة محل ارتكاب الفعل الاجرامي في توقيع العقاب المناسب إذا نص القـانون الأجنبي علي عقوبـة أخف. والثانيـة تتعلق بإهدار مبـدأ عدم جواز محاكمة الشخص الواحد أكثر من مرة عن نفس الفعل إذا عـاد إلـي دولة محل ارتكـاب الفعل الاجرامي قبل توقيع العقوبة(؟)

(1) FURTADO DOS SANTOS, A. : L'application de la loi penale etrangere par le juge national, Rapp. Presente au VIIIe C.I.D.P., in R.I.D.P, 1960, No. 3 et 4, p. 568 et. ss.SCHWANDER, V. : L'application de la loi penale etranger par le juge national, Rapp. Suisse presente au VIIIe C.I.D.P., Lisbonne, 1961, in R.I.D.P., 1960, pp. 576 et. ss. Et. Actes du VIIIe C.I.D.P. de L'A.I.D.P., Paris, 1965, pp. 553 et. ss.

(2) JESCHEK, H.H. , Avant props aux travaux de la 4ème section du VIIIèME congrès de L.A.I.D.P. , in R.I.D.P. 1960 , P. 393 . 
ونتوه هنـا إلـي أن دولـة القـانون الأجنبـي لن تضع في اعتبار هـا قـانون محل ارتكـاب الفعل الاجرامسي إلا للتأكـــ مـن تـوافر شـروط المحاكمـة لاسـيمـا شـرط ازدواج التجريم. بل إن عدم تطبق قانون محل ارتكاب الجريمة، قد يكون مدعاة لارتكاب الكثير مسن الجنـاة لجرائمهم بالخـارج والفـرار لـوطنهم، خاصـة إذا كـانوا يعلمـون مقـدماً أن قانونهم لا يجرمها.

فتطبيق القـانون الجنـائي الأجنبـي تفرضـه ضرورات العدالـة الجنائية واحترام الحريات الفردية بتحقيق المساواة بين المساهمين في الجريمة وتطبيق القانون الخاص بطبيعة الجريمـة ومكـان وقوعهـا لغيـاب معـايير الاختصاص بتحديـ القـانون الواجب التطبيق علي الواقعة، وأخيرا اقرار الدولـة للحكم الجنـائي الأجنبـي لا يكون إلا وفقا للإجراءات والقواعد التي تضعها هي بنفسها، فضلا عن أن فكرة السيادة لم تعد تتنـافي مع التعاون بين الدول(') وينكر اتجاه فقهي سلطة القاضسي الجنائي في تطبيق قانون العقوبـات الأجنبي استناداً لفكرة إقليمية القوانين الجنائية، والتمسك بمبدأ استقلال الدولة وسيادتها، حيث أن هذا التطبيق يمس النظام العام للاولة، باعتبار أن قواعد القانون الجنائي كلها تتعلق بالنظام العام؛ كمـا يستبعد تطبيق القانون الجنائي الأجنبي أمسام القضاء الوطني على

(1) BEHNAAM, R. : L'application par le juge national d'une loi penal etrangere, in R.I.D.P., 1962, PP. 324 et. ss.ROPERS, J. L. : Le droit penal international a travers la jurisprudence de la chambre criminelle, Melanges patin, 1966, pp. 723 et. ss.

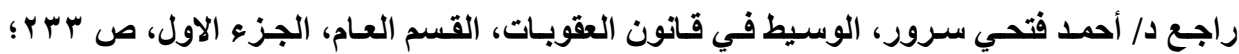

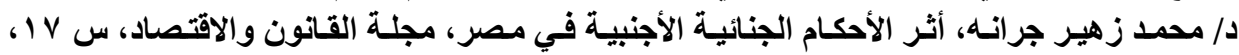

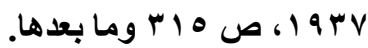


أساس حق الدولة في فرض سيادتها على إقليمها، ولا يقبل للأجنبي الاحتجـاج بجهله بقانون الدولـة التـي ارتكب عليها جريمتـه، فـلا يسمح للقاضـي الوطني أن يطبق أي قانون جنائي أجنبي داخل نطاق حدود إقليمه،، وإلا عد ذلك اعتداء صـارخاً على مبدأ

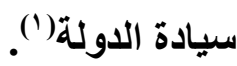

ويترتب علـي ذلـك أن الدولـة يمتـع عليهـا أن تمــ سـلطانها على الأشـخاص المقيمين خارجها، كمـا لا يجوز للاولـة أن تتعقب الجنـاة الذين ارتكبوا جرائم على إقليمها إذا لجأوا إلى إقليم دولة أخرى، ولا تسمح بـأن تقوم دولـة أخرى بأي إجراء داخل نطاق حدودها استنـادا إلـي نظريـة العقد الاجتمــاعي ـ تقوم الدولـة مـن جانبها بواجب المحافظة على أمـنهم ومـصالحهم العامـة، على أن يلتزم الأفراد مـن جـانبهم بالخضوع لأوامر الدولة واحترام مـا تصدره من قوانين لتنظيم حياتهم ـ التي لم تعط تبرير لتوقيع العقاب على الأجانب المقيمين على إقليم الدولة، حيث أنه لـم يكونـوا طرفا في العقد الأي تم بين الاولة ورعاياها المقيمين على أرضها. فضلا عن الاستناد إلي فكرة السيادة ـ لكل دولـة سيادة مستقلة على إقليمها وتباشـر سـلطاتها على جميع المقيمين على أرضها، بصرف النظر عن جنسياتهم أو صفاتهم، فلا يجوز لأي دولة أن تتدخل في اختصاصاتها- التي تتغير وفق سياسة كل دولة، ولا تكون كافية لردع الجرائم التي ترتكب خارج الإقليم وتمس المصلحة العامة للاولة.

(1) CYBICHOWSKI, S. : La competence des tribunaux a raison d'infractions soumises hors du territoire, cours La-Haye, 1926, T, II, PP. 265 et. ss. GARRAUE, R. : Traite theorique et pratique du droit penal francais, T.I, $3^{\mathrm{e}}$ ed, Librairie du recueil sirey, Paris, 1913, P.345. 
فاختصاص قاضـي محل ارتكـاب الفعل سـيوفر لـه المعايشة الحقيقيـة لظروف

ارتكاب الجريمة مما يجعل الحكم مبنيا علي أسس سليمة ـ حيث السهولة الكاملة في جميع الأدلة وسؤال الثهود، وإجراء المعاينات وسرعة إنجاز التحقيقات والبت فيها، بالإضافة إلى الاقتصاد في نفقات إجراءات المحاكمـة ـ ويضاف إلي ذلك أن اختصاص قاضي محل ارتكاب الفعل يهلئ مشـاعر السخطو وعدم الرضا لدي المجتمع لردع الجـاني

$$
\text { مباثرة بأقرب مكان وقعت عليه الجريمة(') }
$$

فقيام الدولة التي وقعت على أرضها الجريمة بتوقيع الجزاء على الجـاني طبقاً لقانونها الداخلي يحقق مصلحتين الأولي خاصـة بالدولة التي خرق قانونها، والثانيـة خاصة بتحقيق مصلحة البرية وهدفها على المستوي الدولي وهو ردع الإجرام "فقيام كل دولة بتنفيذ قوانينها وضبط المخالفين لها يحمي الدول الأخرى من خطر هذا الجـاني

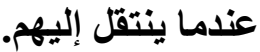

وفي هذا السياق نُشير إلي أن تطبيق القانون الجنائي الأجنبي يصطدم بصعويات عديدة، فقد يتضمن هذا القـانون عقوبـة لا يجرمها القـانون الوطني. فضلا عن تعذر الإلمـام بـالقوانين الجنائيـة الأجنبيـة، حيث قد لا يتـاح للقاضـي الوطني معرفة القـانون الأجنبي أو تحديا مضمونه أو تفسيره أو كيفية إثباته. كذلك لا تتحقق وحدة الخصوم في الحكم الجنائي الأجنبي واللاعوى الجنائية المرفوعة أمسام المحاكم الوطنية، لاختلاف الادعاء العام من دولة إلى أخري. كمـا أن الحكم الجنـائي الأجنبي قد يتأثر في ظروف

(1) ZLATARIC, B. : L'application de la loi pénal étrangère par le juge national in actes du VIIIe C.I.D.P. Paris 1965, pp. 172 et. ss. 
معينة ببعض الاعتبارات السياسية، وربما تقتضي هذه الظروف مؤاخذة المتهم بالشدة إذا ما حوكم أمام المحاكم الوطنية"(1)

وخلاصة ما سبق يمكن القول أن الاتجـاه المنكر لتطبيق القانون الأجنبي أمسام

القاضي الجنائي يؤسس فكرته علي أساس عدم الثقة في التشريعات الجنائية الأجنبية والقضاء الأجنبي، ويمكن تفنيد ذلك بأن تشريعات الدولة التي ارتكبت عليها الجريمـة تكون متماثلة في معظم الحالات، أو على الأقلّ شبيهة بتشريعات بلد المحاكمة. كمـا أن الثابت أن القاضـي المـدني يقبل تطبيت قـانون محل الفعل الغير مشروع في حسالات التعويضات للمجني عليهم، مع تحفظ احترام النظام العام الدولي. والقول بخيار القاضي الجنائي الوطني قبل تطبيق القانون الأجنبي يتوقف علي نوع العقوبة وإمكان تطبيقها ـبدنية أو مالية ـ فيمتنع تطبيق الأولى دون الثانية، يمكن الرد عليه بأن الاشكالية تتعلق بالقـانون الواجب التطبيق بصرف النظر عن مضمونه حيث تطبيق القانون الجنائي الأجنبي الأصلح للمتهم لتحقيق المساواة بين الشركاء في

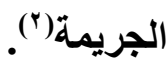
ويمكن التظلب على مشكلة اختلاف العقوبـات بين قوانين الدول بعمل قائمـة بالعقوبات المقارنة بين القوانين، أو تثبيه الجزاء في القانون الأجنبي بجزاء مماثل في القانون الوطني يحكم به القاضي لإزالة صعوبات تفسير القوانين الجنائية الأجنبية أو

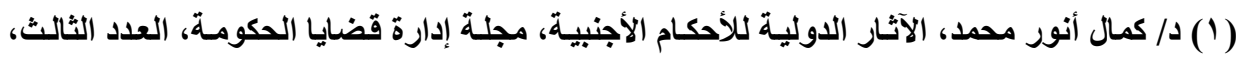

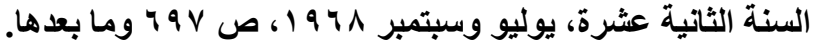

(2) SCHWANDER, V. : Actes du VIIIe C.I.D.P. de L'A.I.D.P., Paris, 1965, pp. 553 et. ss. 
وجود عقوبة منصوص عليها في القانون الأجنبي وغير منصوص عليها في قانونه، أو قد يقوم بتطبيق هذا القانون تطبيقاً خاطئاً يترتب عليه الإضرار بالنظام العام لبلد محل

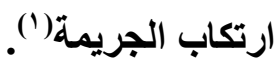

كمـا أن هنـاكك عدة قيود تلزم القاضـي الوطني أثنـاء تطبيقهـ للقوانين الجنائيـة

الأجنبية بعدم مخالفة النظام العام الداخلي أو المساس بالجرائم السياسية أو العسكرية. علاوة على ذلك، فإن القاضي الوطني يقوم بتطبيق القوانين الجنائية الأجنبية وتفسيرها برمتها ويخضع ذلك لرقابة محكمة النقض والمحكمة العليا.

(1) LOUSSOUARN, Y. : Le contrôle par la cour de cassation de l'application des lois etrangeres, Travaux du comite francais de droit international prive (1962-1964), Paris 1965, pp. 136 et. ss. 


\section{المبمث الثاني}

\section{الأساس القانوني لتطبيق القاضي الجنائي للقانون الأجنبي}

يمكن للقاضي الوطني تطبيق القانون الأجنبي عن طريق التعاون الدولي الذي

تظهر صوره في عقد الاتفاقيات الثنائية أو متعددة الأطراف بغية التوصل إلي شرعية تطبيق هذه القوانين دون تحميل النصوص أكثر مما تحتمل.

يتمثل الأساس القانوني في تطبيق القاضي الجنائي للقانون الأجنبي سواء على

المستوي العالمي عن طريق المعاهدات والمؤتمرات الدولية، أو على المستوي المحلي عن طريق عقد الاتفاقيات الثنائية فيما بين الدول، أملا في تضييق فرص هرب أو نجاة الجناة من الخضوع للمحاكمة، وإنزال العقاب بهم. فالاتفاقيات الدولية دعامـة ضرورية وحتمية لاحترام حقوق الانسان والالتزام بقواعد القانون الجنائي الدولي (')

فالتسليم وفقـا للاتفاقية الأوربيـة الخاصة بتسليم المجرمين يقصد بـه السماح

بتسليم فاعل الجريمة للاولة التي وقعت عليها الجريمة، ليطبق عليه قانون محل الفعل الإجرامي، طبقاً لمبدأ الإقليمية، مع الاحترام المتبادل للقوانين الداخلية للاول الأعضاء في المجلس الأوربي.

(1) KOERING-JOULIN, R. : Structutes et methodes de la cooperation repressive internationale et regionale, (a l'exclusion de l'extradition), Actes du colloque preparatoire au XIIIe congres international tenu strasbourg (France), 5-7 sep. 1983, R.I.D.P.,1984, No. 1 et 2, pp. 147 et. ss. 
وقد حددت الاتفاقية النصوص المتعلقة بحرية الدول المطلوب منها التسليم في رفض هذا الطلب، حيث تبرز العلة من الفقرة الأولي في المسادة السابعة والتي تنص على "أن الاولـة المطلوب منها التسليم، تستطيع رفضه إذا ارتكبت الجريمـة ـ طبقاً لتشريعها - على كل أو جزء من إقليمها، أو في مكان مماثل له" في تغليب الاختصاص الوطني للاولة المطلوب منها التسليم، طبقاً لمبدأ الإقليمية، وقد تركت الاتفاقية للاولتة المطلوب منها التسليم، أن تعتنى بتحديد ما إذا كاتت الجريمة - طبقاً لتشريعها الوطني - واقعة على إقليمها مـن عدمسه، مـع رفض التسليم إذا مـا كانت الجريمـة المطلـوب بسببها التسليم قد وقعت على كل أو جزء من إقليمها أو ما يماثله('). بينما نجد المادة Y/V من نفس الاتفاقية والتي تنص على" إذا كانت الجريمـة التي كاتت سبياً لطلب التسليم، قد وقعت خارج إقليم الدولة الطالبة، فإن التسليم لا يكون مرفوضـاً إلا إذا كـان تشريع الدولـة المطلـوب منهـا التسليم، لا يسمح بالمحاكمـة عن جريمة من نفس النوع المرتكب خارج إقليمها، أو لا يسمح بالتسليم من أجل الجريمـة المطلوب عنها التسليم." تنكر الأخذ بمطلق مبأ الإقليمية في العلاقات الدولية، وتؤكد

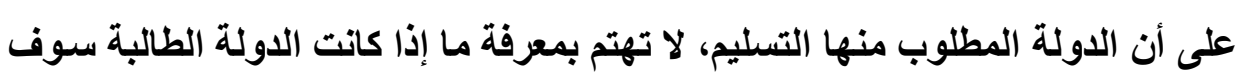
تمـارس اختصاصها بنـاء على مبدأ الإقليمية، أو تحت أي مبدأ من المبادئ الأخرى،

(1) Article 7 - Place of commission 1 The requested Party may refuse to extradite a person claimed for an offence which is regarded by its law as having been committed in whole or in part in its territory or in a place treated as its territory. 
وليس لها إلا بيـان مـا إذا كـان تشريعها يعارض هذه المحاكمـة أم لا ـ لهذا النوع من

الجرائم المطلوب عنها التسليم ـ لكي تحدد موافقتها على التسليم من عدمه(').

كمـا تستطيع الدولـة المطلـوب منهـا التسليم رفضه، إذا كـان الفرد المطلـوب

تسليمه يعد محلاً لمحاكمـات، أو إذا كاتت هنـاك وقائع للجريمـة متعلقة بطلب التسليم.

فالمـادة الثامنـة مـن الاتفاقيـة تؤكد على أولويـة الاختصـاص الإقليمسي شـرط ضـرورة

استلزام توافر المصلحة العليا لتظليب ذلك الحل أو غيره والتي تتجلي في تطبيق العقوبة المناسبة أو إعادة إدماج المحكوم عليه في المجتمع(؟).

أما مشكلة التعدد الخـاص بطلبات التسليم عن الوقائع المختلفة فيمكن تحديد

الاختصاص تبعا لمكان الجريمة والتواريخ المتعلقة بطلبات التسليم، وجنسية الشخص

المسلم وفق ما نصت عليه المادة V V المعنونة بقبول الطلبات("). إلا أن مـا سبق ذكره

(1) Article 7 - Place of commission 2 When the offence for which extradition is requested has been committed outside the territory of the requesting Party, extradition may only be refused if the law of the requested Party does not allow prosecution for the same category of offence when committed outside the latter Party's territory or does not allow extradition for the offence concerned.

(2) ZLATARIC, B. : L'application de la loi pénal étrangère par le juge national in actes du VIIIe C.I.D.P. Paris 1965, pp. IV $\leqslant$ et. ss. Article 8 Pending proceedings for the same offences The requested Party may refuse to extradite the person claimed if the competent authorities of such Party are proceeding against him in respect of the offence or offences for which extradition is requested.

(3) Article 17 - Conflicting requests If extradition is requested concurrently by more than one State, either for the same offence or for $=$ 
لا يحول دون حق الدولة المطلوب منها التسليم رفضه في حالة تسليم الرعايا الوطنيين دون الاخلال بحق الدولة المطلوب منها التسليم، في رفع الدعوى الجنائية عن الجريمة المطلوب عنها التسليم أمسام المحكم الوطنيـة، ويستعان في ذلك بـالطرق الدبلوماسية لأخذ المعلومات الخاصة بالجريمة من الدولة الطالبة(').

كما قضت المادة ب/ من هذه الاتفاقية، بأن الوقائع لا تكون محلاً للتسليم، إلا

إذا كان معاقبً عليها بواسطة قوانين الدولة الطالبة والدولة المطلوب منها التسليم على السواء. فاستلزام أن تكون الواقعة معاقباً عليها بمقتضي قوانين الدولـة المطلوب منها التسليم لا يجد ما يبرره، حيث أن الجـاني لم يمس أو يخـالف أيـا من القواعد الجنائية لتلك الدولة، بل أن من مصلحة تلكك الدولة التي تـأوى الجـاني أن تتخلص من وجوده على أرضها، والذي قد يشكل نوعاً من الخطورة عليها مستقبلا"(). والتمسك بنص هذه

different offences, the requested Party shall make its decision having regard to all the circumstances and especially the relative seriousness and place of commission of the offences, the respective dates of the requests, the nationality of the person claimed and the possibility of subsequent extradition to another State.

(1) Article 6 - Extradition of nationals 2 If the requested Party does not extradite its national, it shall at the request of the requesting Party submit the case to its competent authorities in order that proceedings may be taken if they are considered appropriate. For this purpose, the files, information and exhibits relating to the offence shall be transmitted without charge by the means provided for in Article 12, paragraph 1. The requesting Party shall be informed of the result of its request.

(2) Article 2 - Extraditable offences 1 Extradition shall be granted in respect of offences punishable under the laws of the requesting Party and of the requested Party by deprivation of liberty or under a detention $=$

9. 
الاتفاقيـة قد يـؤدي إلسى نتيجـة غيـر منطقيـة وهـي عدم تسليم المجرم لعـدم تجريم

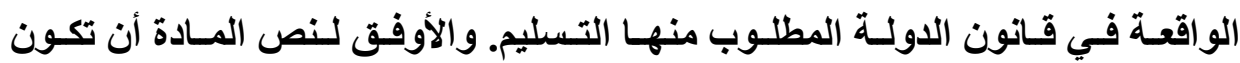
الوقائع محلا للتسليم إذا كان معاقبا عليها بواسطة قوانين الدولة الطالبة ودولـة محل ارتكـاب الجريمـة. كمـا أن التمسك بنص المـادة على وضعه القديم يعطي حمايـة غير مباشـرة ومؤقتـة لـرهن المحاكمـة وإعـادة طلـب التسليم وفـق الظـروف والأوضــاع

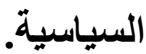

وامتـ نطاق هذه الحمايـة إلـي تطلب شرط المعاملة بالمثل والذي سـاهم بشكل

ملحوظ في تأييد عدم القصاص من الجنـاة، أي فرض نوع من الحصانة لهم حتى لا يقدموا للمحاكمة عن طريق دولة أخرى، طالما أن هذه الأخيرة لا تتمسك بهذا المبدأ('). فالاتفاقية أعطت للاولة المطلوب منها التسليم، الحق في رفض تسليم المجرمين، في حالة مـا إذا كانت الدولة الطالبة تنص في قانونهـا على رفض التسليم لنفس الوقائع

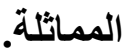

order for a maximum period of at least one year or by a more severe penalty. Where a conviction and prison sentence have occurred or a detention order has been made in the territory of the requesting Party, the punishment awarded must have been for a period of at least four months.

(1) Article 1 - Obligation to extradite The Contracting Parties undertake to surrender to each other, subject to the provisions and conditions laid down in this Convention, all persons against whom the competent authorities of the requesting Party are proceeding for an offence or who are wanted by the said authorities for the carrying out of a sentence or detention order. 
فالاتفاقية الأوربية الخاصة بتسليم المجرمين أيدت - بصفة خاصة ـ معارضتها

للتسليم في الجرائم السياسية ، وقد أعلنت ذلك صراحة لاعتبـارات العدالة، ولرغبة الاول المشتركة في الاتفاقية في حماية الإنسان عن طريق فرض عدالة متميزة بالحيدة والإنصاف. كما قضت الفقرة الثانية من المادة الثالثة بعدم قبول التسليم في حالة مـا إذا كاتت الدولة المطلوب منها التسليم، لايها أسباب جدية في الاعتقاد بأن طلب التسليم قد حرك بهدف جريمـة في القـانون العـام، مـن أجل تتبـع الجـاني واقتفــاء أثره، لتقديمـه للمحاكمـة أو لنيل العقاب من أجل اعتبـارات ترجع إلى الايانـة، أو الجنسية أو الآراء

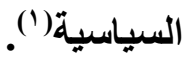
وكذلك الحسال لا يعد مقبولا تسليم المجرمين في جرائم القصر؛ حيث لا يحكم عليهم بعقوبة سالبة للحرية، ولكن يمكن الحكم عليهم بالغرامـة، ومن غير المعقول أن يسلم هؤلاء الجناة من الأطفال لينالوا جزاء صـارماً على المستوي الدولي. كمـا أنها من الناحية النظرية هنالك صعوبة بالغة تمنع من تنفيذ العقوبة السالبة للحريـة في بلد آخر على جان لم يرتبط بها بأي صلة.

ونشير في هذا السياق إلي أن هنـاك علاقة وطيدة مـا بين الاتفاقية الأوربيـة

لتسليم المجرمين وحقوق الإنسان، ويظهر ذلك في رفض تسليم المجرمين للاعتبارات الإنسانية سـواء المرتبطة بالشخص المطلوب تسليمه، أو المتعلقـة بالعقوبـة القابلـة

(1) Article 3 - Political offences 2 The same rule shall apply if the requested Party has substantial grounds for believing that a request for extradition for an ordinary criminal offence has been made for the purpose of prosecuting or punishing a person on account of his race, religion, nationality or political opinion, or that that person's position may be prejudiced for any of these reasons. 
للتطبيق. فالاعتبارات الإنسانية تقود إلى تفضيل الاختصاص الإقليمي وتوقيع العقاب

المناسب على المذنب خاصة في ظل الصعوبات الخاصـة بالنقل للاولـة الطالبة. كمـا أن الاولة التي تأوى الثخص الذي ارتكب جريمة ما ــ إذا ما تضررت من عملية التسليم ـ لها أن تقوم بمباشرة الإجراءات الجنائية قبله، مع الوضع في الاعتبار تطبيق قانون محل ارتكـاب الفعل، احترامـاً لحقوق الإنسـان، وتمسكاً بمبـأ الشرعية الذي يـرتبط ارتباطاً وثيقًاً بمكان ارتكاب الواقعة الإجرامية.

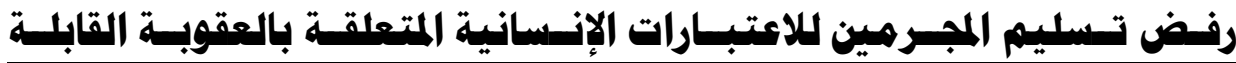

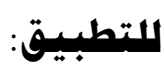

تقضي المادة 11 من الاتفاقية الأوربية لتسليم المجرمين بأنسه إذا كانت الواقعة

التي طلب بسببها التسليم، معاقباً عليها بعقوبة الإعدام بواسطة قانون الدولـة الطالبة، فإن كانت هذه العقوبة لم يكن منصوصاً عليها في تثريع الدولة المطلوب منها التسليم، أو بصفة عامة غير قابلة للتففيذ، فبان التسليم لا يصادف قبولاً، إلا تحت شرط ضمان الدولة الطالبة إصدار حكمها بالعقوبة المناسبة، مع استبعاد تتفيذ عقوبة الإعدام ('). ونلاحظ علي هذه المادة أنها حفاظا علي حقوق الانسسان تجعل للاولة المطلوب

منهـا التسليم الحق في التذرع لرفض التسليم عبر مناقشة الدولـة الطالبة في طرق

(1) Article 11 - Capital punishment If the offence for which extradition is requested is punishable by death under the law of the requesting Party, and if in respect of such offence the death-penalty is not provided for by the law of the requested Party or is not normally carried out, extradition may be refused unless the requesting Party gives such assurance as the requested Party considers sufficient that the death-penalty will not be carried out. 
وأساليب العقاب قبل التسليم. أمسا الجنـاة الذين تم تنفيذ الحبس الاحتياطي ضدهم في الدولة المطلوب منها التسليم قبل أن تتم محاكمتهم ، فإن الاتفاقية قد حددت في المسادة 17 تحت عنوان "الحبس الاحتياطي " أو الحبس المؤقت للأشخاص المطلوب البحث عنهم، أنه بمقتضي الطلب اللاحق للتسليم، فإن الدولة المطلوب منها التسليم يمكن أن تحتج في رفضه، إذا لـم تأخـذ التعهدات اللازمـة بخصم مـدة الحبس الاحتيـاطي التي قضاها المتهم بالخارج، وذلك ضماناً لحقوق الإنسان واعتبارات العدالة('). وإذا كانت هذه الاتفاقية قـ اهتمت بضرورة الوضع في الاعتبـار كل الظروف الخاصة بالمتهم المطلوب تسليمه، وبصفة خاصة تلكك المتعلقة بحقوق الإنسان، إلا أنـه قد اعتراهـا العديـ من الصعوبات المتعلقة بـإجراءات التحقيق، والتـي كانت للاتفاقية الأوربيـة الخاصـة بتحويـل الإجـراعات الجنائيسة، الفضل الأول فـي القضاء على تلـك

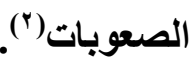

وضـعت الاتفاقية شـروطاً خاصـة بالجريمـة تتعلق بـازدواج التجريم ــ المـادة

السابعة ـكسبب لتحويـل المحاكمـات في كلتـا الدولتين الطالبـة والمطلوب منهـا اتخـاذ الإجراء. فضلا عن ضرورة تكييف الواقعة الإجرامية بالنسبة لقانون الدولـة المطلوب

(1) Article 16 - Provisional arrest 1 In case of urgency the competent authorities of the requesting Party may request the provisional arrest of the person sought. The competent authorities of the requested Party shall decide the matter in accordance with its law.

(r) كاتت هذه الاتفاقية ثمرة جهود فقهاء القانون الجنائي في الدول الأوروبيـة حيث عكف هؤلاء

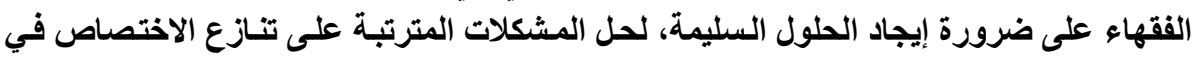

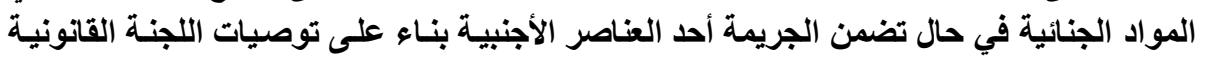
للجمعية الاستثارية للمجلس الأوروبي. 


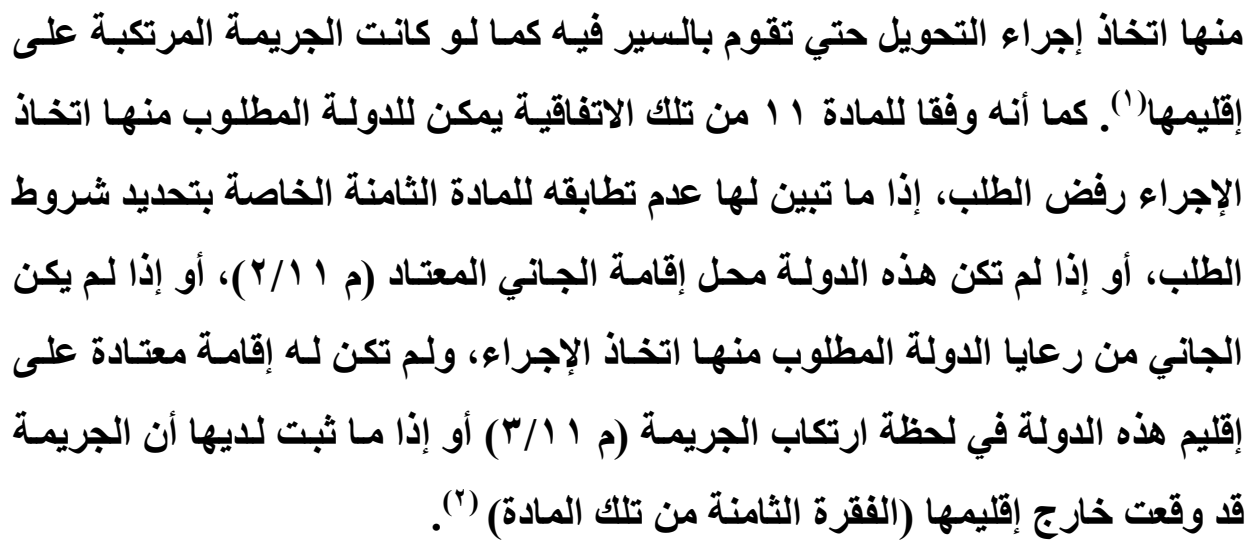

(1) Article 71 Proceedings may not be taken in the requested State unless the offence in respect of which the proceedings are requested would be an offence if committed in its territory and when, under these circumstances, the offender would be liable to sanction under its own law also. 2 If the offence was committed by a person of public status or against a person, an institution or any thing of public status in the requesting State, it shall be considered in the requested State as having been committed by a person of public status or against such a person, an institution or any thing corresponding, in the latter State, to that against which it was actually committed.

(2) Article 11 Save as provided for in Article 10 the requested State may not refuse acceptance of the request in whole or in part, except in any one or more of the following cases: $b$ if the suspected person is not ordinarily resident in the requested State; $\mathrm{c}$ if the suspected person is not a national of the requested State and was not ordinarily resident in the territory of that State at the time of the offence; $h$ if the offence was committed outside the territory of the requesting State; 
ولقد نصت الاتفاقية على الإجراءات الواجب إتباعها لتحويل الاختصاص من

الدولة الطالبة إلى الدولة المطلوب منها اتخاذ الإجراء عبر منح الدولـة المطلوب منها إجراء المحاكمة الاختصاص، طبقاً لقانونها الجنائي، بنـاء على طلب المحاكمـة المقدم من الدولة الطالبة (م Y/Y) (1) . وفي حالة اختصاص العديد من الدول المتعاقدة، فإن أي دولة تختص بالمحاكمة يجب أن تعلن ابتداء التعهد بالمحاكمة أو تركها، ليقتفي أثر المجرم بمعرفة دولـة أخرى طرف في الاتفاقيـة. وإذا أعلنت تلكك الاولـة اختصاصها اعتبر ذلك القرار نهائيا، ويمنع التدخل من أي من الدول الأخرى، وذلك منعاً لتعدد المحاكمات عن نفس الواقعة، لما في ذلك من إهدار لأبسط مظاهر العدالة. ويحظر على الدولة الطالبة أن تقوم بإجراء المحاكمة أو التنفيذ من أجل الوقائع التي كاتت محلا لطلبها، إلا في حالة تقاعس الدولة المطلوب منها الإجراء عن القيام به

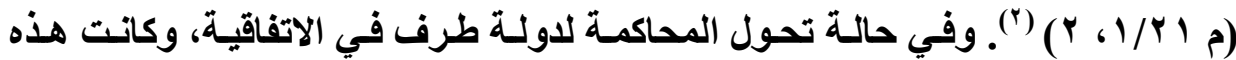

(1) Article $r / r$ The competence conferred on a Contracting State exclusively by virtue of paragraph 1 of this article may be exercised only pursuant to a request for proceedings presented by another Contracting State.

(2) Article 211 When the requesting State has requested proceedings, it can no longer prosecute the suspected person for the offence in respect of which the proceedings have been requested or enforce a judgment which has been pronounced previously in that State against him for that offence. Until the requested State's decision on the request for proceedings has been received, the requesting State shall, however, retain its right to take all steps in respect of prosecution, short of bringing the case to trial, or, as the case may be, allowing the competent administrative authority to decide on the case. 
الاولة مختصة أصـلاً بالمحاكمـة، فِإن المسادة الخامسة من تلك الاتفاقية، أعطت لهذه الدولة الحق في وقف السير في الطلب المقدم من الدولة الطالبة، والسير في الإجراءات طبقاً لقانونها الخاص("). ويشترط ألا يكون ذلك القانون أشد قسوة من قانون الدولـة

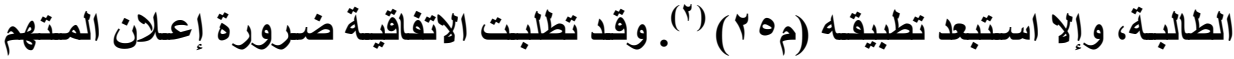
بطلب المحاكمـة، حتى يعد دفاعه وأسـانيده ضـماناً لحقوق الدفاع، واحترامـاً لدقوق

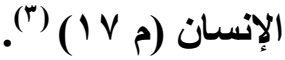

ووضعت المادة الخامسة من الاتفاقية الأوربية الخاصة بالقيمة الدولية للأحكام

الجنائية الحجج التي يمكن للاول بمقتضاها رفض طلب التنفيذ إذا كانت إقامـة المحكوم

عليه المعتادة في دولة أخرى أو إذا كان تنفيذ العقوبة في دولة أخرى، قد يؤدي إلى أكبر قدر ممكن من إصـلاح المحكوم عليه،، وإعـادة إدماجـه في المجتمـع أو إذا كانـت

(1) Article 5 The provisions of Part III of this Convention do not limit the competence given to a requested State by its municipal law in regard to prosecutions.

(2) Article 25 In the requested State the sanction applicable to the offence shall be that prescribed by its own law unless that law provides otherwise. Where the competence of the requested State is exclusively grounded on Article 2, the sanction pronounced in that State shall not be more severe than that provided for in the law of the requesting State.

(3) Article IV When the requesting State has requested proceedings, it can no longer prosecute the suspected If the competence of the requested State is exclusively grounded on Article 2 that State shall inform the suspected person of the request for proceedings with a view to allowing him to present his views on the matter before that State has taken a decision on the request. 
العقوبة السالبة للحرية يمكن تنفيذها في دولة أخرى، تبعاً لعقوبة أخرى سـالبة للحريـة

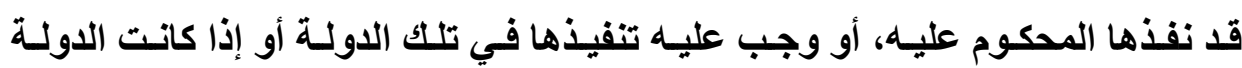

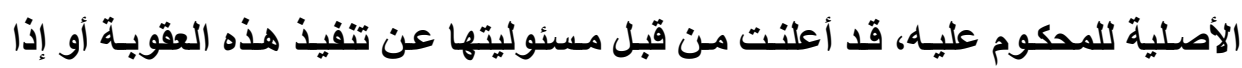
استحال تنفيذ العقوبة، فيمكن الرجوع إلى نظام تسليم المجرمين لتسليم المحكوم عليه

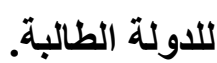

ومن جماع ما سبق يتضح أن القانون الواجب التطبيق علي الواقعة هو قانون

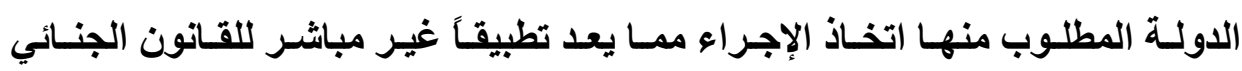
الأجنبي، حيث إن الجريمة قد ارتكبت على إقليم دولة معينة، وتمت المحاكمة على إقليم

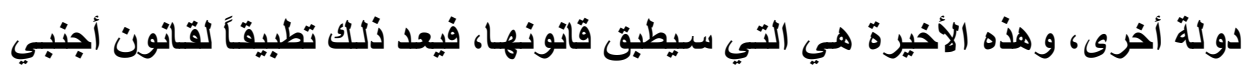

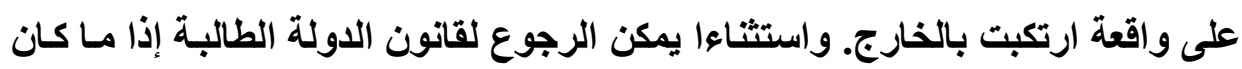

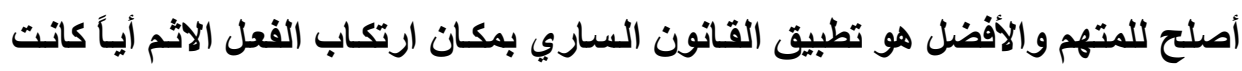

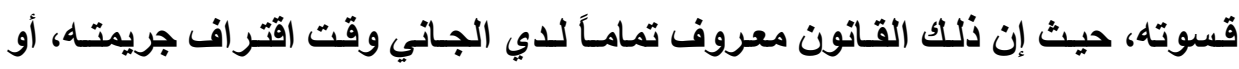

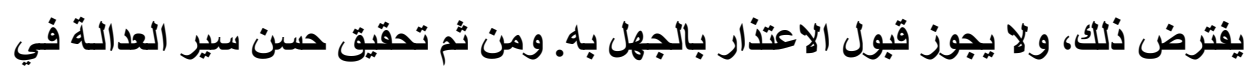

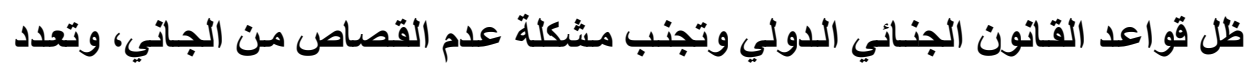
العقوبات، عن طريق تنظيم طرق المساعدة القضائية. و إذا كانت الاتفاقيـة الأوربيـة الخاصـة بتسليم المجرمين قد استبعدت تسليم

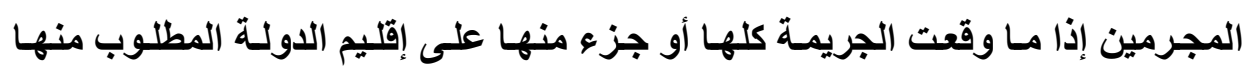

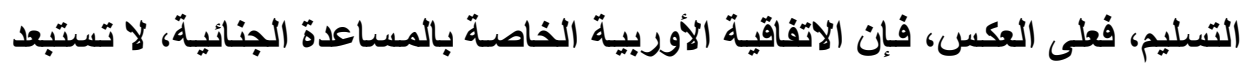

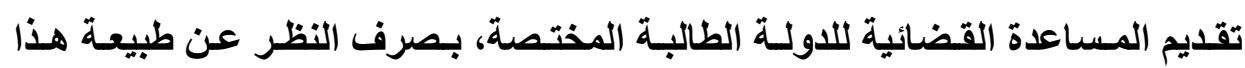
الاختصاص، وبصرف النظر عن اختصاص الطرف الآخر. فالمساعدة القضائية طبقاً لنص المادة ץ/ r من الاتفاقية الأوربية الخاصة بالمساعدة القضائية في المواد الجنائية 
يمكن أن ترفض إذ قدرت الدولة المطلوب منها المساعدة أن طبيعة هذه المساعدة تحمل اعتداء على السيادة أو الأمن أو النظام العام أو المصالح الأساسية للاولة مـع ضرورة التقيد بشرط المعاملة بالمثل (').

أما بالنسبة لشرط إزدواج التجريم، فإن هذه الاتفاقية قد استبعدت هذا الشرط

من نطاق تطبيقها، إلا أن استلزام شرط إزدواج التجريم، يكون مطلوباً في حالة الإنابـة القضائية بهـدف البحث والتحرى والتحقيق، أو القبض على الجنـاة بمعرفـة الدولـة المطلوب منهـا المساعدة، حيث قضت المسادة ه من هذه الاتفاقية بـأن تنفيذ الإنابـة القضائية يتطلب عدة شروط منها أن تكون الجريمـة محلا للتسليم في الدولة المطلوب منها المساعدة. وأن تكون الجريمـة قابلـة للعقـاب طبقاً لقانون الدولـة الطالبـة والدولـة المطلوب منها المساعدة على السواء. وأن يكون تنفيذ هذه الإنابة مطابقاً لقانون الدولة المطلوب منها المساعدة(†). وفي الواقع أن استبعاد شرط ازدواج التجريم في حالات

(1) Article $r / r$ Assistance may be refused: $b$ if the requested Party considers that execution of the request is likely to prejudice the sovereignty, security, ordre public or other essential interests of its country.

(2) Article 51 Any Contracting Party may, by a declaration addressed to the Secretary General of the Council of Europe, when signing this Convention or depositing its instrument of ratification or accession, reserve the right to make the execution of letters rogatory for search or seizure of property dependent on one or more of the following conditions:

a that the offence motivating the letters rogatory is punishable under both the law of the requesting Party and the law of the requested Party;

$=$ 
معينـة يعد خطوة طيبـة لتحقيت العدالـة الاجتماعيـة السليمة بهـدف محاربـة الإجـرام

$$
\text { وتضييق فرص هرب الجناة. }
$$

فالاتفاقيـة الأوربيـة الخاصـة بالقيمـة الدوليـة للأحكـام الجنائيـة تستلزم ازدواج

التجريم مـن ناحيـة المطابقة أو المماثلـة بين الوقائع، بغض النظر عن التكييف، أو الخطورة الجنائية المترتبة عليها. فالدولة المطلوب منها التنفيذ لها الأولويـة في حق إقرار تنفيذ الحكم الأجنبي من عدمه، بصرف النظر عن طبيعة اختصاص الدولة الطالبة حيث يمكن رفض تنفيذ الحكم الجنـائي الأجنبي للأسباب الآتية إذا كانت الجريمـة محل الحكم قد وقعت خارج إقليم الدولة الطالبة. وإذا كان قانون الدولة المطلوب منها التنفيذ، لا ينص على نفس العقوبة الصادرة من الدولة الطالبة كذلك يشترط ألا تكون العقوبـة المطلوب تنفيذها، قد نفذت في الدولة المطلوب منهـا التفيذ عن نفس الجريمـة وألا تكون هذه العقوبة قد تقادمت طبقاً لقانون الدولـة الطالبة وألا يكون الحكم الأجنبي قد سـط بالتقـادم. إلا أن استبعاد تنفيذ الحكم بسبب وقوع الجريمـة خـارج إقلّيم الدولـة الطالبة يعد محل نظر، حيث أن تلك الدولة قد يلحقها من الأضرار والخسائر مـا يفوق وقوع هذه الجريمة على إقليمها، فليس من المنطق أن تتلخل دولة لفرض اختصاصها،

b that the offence motivating the letters rogatory is an extraditable offence in the requested country;

c that execution of the letters rogatory is consistent with the law of the requested Party.

2 Where a Contracting Party makes a declaration in accordance with paragraph 1 of this article, any other Party may apply reciprocity. 
وإصدار حمم في واقعة تمت خارج إقليمها، دون أن يكون لايها أسباب مقبولة تبرر ذلك

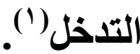

وفي الواقع أن تحديد الأسباب التي من أجلها يرفض طلب التسليم على سبيل

الحصر، يعد أفضل مـن أن يترك الأمسر لطلب الاستفسار أو الإيضاح عن معنى أو الو مضمون تلكك المادة أو ضوابط ذلك المعيار. ويمكن للاولة المطلوب منها التنفيذ رفضه إذا أدي إلى مخالفة المبادئ الأساسية للنظام القـانوني، للاولة المطلوب منهـا التنفيذ (م/1/1 ) أو إذا كان مخالفاً للارتباطات الدولية المطلوب منها التنفيذ (م ^/ء).

وترتبت بعض الآثار على تحول التنفيذ في الاتفاقية الأوروبية الخاصـة بالقيمـة

الاوليـة للأحكـام الجنائية، والتـي نظمت تحويل الاختصاص مـن الدولـة المطالبـة إلى الدولة المطلوب منها التنفيذ، بناء على طلب يقدم إليها بهذا الشأن(؟). وتتحصر آثار هذا التنفيذ في فرض ضمانات للمحكوم عليه، ومعادلة حكم الإدانة، ومطابقة العقوبة، وذلك على النحو التالي :أ) الضهانات المئنوحة للامشكوم عليه:

تقـر الاتفاقيـة ضـرورة ضـــان احترام حقوق الــفاع، فالدولـة المطلـوب منهـا التنفيذ، يجب عليها أن تمكن المحكوم عليه من إبداء وجهة نظره بشأن حكم الإدانـة

(1) BREUKELAAR, W.: La reconnaissance des jugements répressifs étrangers, in R.I.D.P., 1974, PP. 565 et. ss.

(2) KOERING-JOULIN, R. : Structurés et méthodes de la coopération répressive internationale et régionale, (a l'exclusion de l'extradition), Actes du colloque préparatoire au XIIIe congres international tenu Strasbourg (France), 5-7sep. 1983, R.I.D.P.,1984, No. 1et 2, pp. 147 et. ss. 
الصـادر ضـده، وهذه الضمـانة ليست مطلقة، إلا فيمـا يتعلق بـالحكم الواجب النفــاذ، فالقاضي غير ملزم بإجابة طلب المحكوم عليه بتففيذ الدكم الصادر ضده، في أي من الاولتين الطالبة والمطلوب منها التنفيذ، فهي سلطة تقديرية للقاضي (م 9 9 / ).

\section{ب) همادلة هكم الإدانة الأجنببي:}

يترتب على تحول التنفيذ، ضرورة صدور حكم من قاضي الدولة المطلوب منها التنفيذ، بأمر فيه السلطات المختصة، بضرورة وضع ذلك الحكم الأجنبي موضع التنفيذ، (م TV من تلك الاتفاقية). ويشترط أن يستند هذا الحكم على اعتبارين همـا ضرورة حماية حقوق المحكوم عليه وبيان طبيعة الشروط المادية لمنح الأمر بالتنفيذ. والأمر بالتنفيذ لا يجب مراجعته من حيث موضوع الاعوى، فالمادة ب ؛ من تلك . الاتفاقيـة تـــص على أن الدولـة المطلـوب منهــا التفيــذ، تـرتبط بتحقيقــات الوقـائع المعروضة عليها كما هي، ويمكنها أن تتعرض فقط للإجراءات الخاصة بتنفيذ الحكم، دون التعرض من جديد لفحص مضمونه أو فحواه، فحكم الأمر بالتتفيذ في حقيقة الأمر، عبارة عن معادلة لحكم الإدانة الأجنبي. لكن المادة . ؛ من تلكك الاتفاقية عددت النقاط التي يمكن لقاضسي الدولة المطلوب منهـا التنفيذ فحصها وهي التأكد من أن العقوبـة موقعة بواسطة حكم نهائي جنائي أوربي والتأكد من وجود ازدواج في التجريم والتأكد من أن التنفيذ مطابق للمبـادئ الأساسية في نظامـه القـانوني (م / / ) و التأكد من أن التنفيذ لا يصطدم مع قاعدة عدم جواز محاكمة الثخص الواحد مرتين عن نفس الجرم والتي نص عليها في الاتفاقية (م به). والتأكد من خضوع أحكام الإدانـة الغيابيـة أو الأوامر الجنائية للشروط اللازمة في الاتفاقية. 
وضعت الاتفاقية القواعد الخاصة التي بمقتضاها، تعد العقوبة مطابقة لقوانين

الدولة المطلوب منها التنفيذ. فيما يتعلق بالعقوبات السالبة للحريـة، فبان كل عقوبـة أو جزء منها قد نفذ على المحكوم عليه في الدولـة الطالبة، تخصم بالكامل من العقوبـة الواجبة التفيذ (م ץ \&). كما أن فترة الحبس الاحتياطي التي قضاها المحكوم عليه في الاولة الطالبة، تخصم أيضا من تنفيذ الحكم الصاد بالإدانة (م ع ؛). وفيمسا يتعلـق بالغرامـات، والمـصادرات (م ه ؛ إلـى ^ \&)، فالاتفاقيـة قـررت بوضوح تام تحويل أو استبدال الغرامات بالوحدة النقدية للاولة المطلوب منها التفيذ، وقد حددت أن المصادرة لا تتم إلا إذا نص عليها بواسطة قانون تلك الدولة، أو أن ذلك القانون يسمح بإصدار عقوبات أكثر شدة من تللك التي صدرت بواسطة الدولـة الطالبة. ونخلص مـن ذلـك إلـى أن قاضـي الدوبـة المنفـذة يستطيع مطابقة العقوبـة الـصادرة بالخارج بتشريعه الخاص.

فاستبعاد المحاكمـات الجديدة عن نفس الجريمسة طبقاً للفـادة به/ 1 من تلك الاتفاقية يقصد به الثخص الأي يصدر عليه حكم جنائي أوربي لواقعة معينة، لا يجوز إعادة محاكمته أو خضوعه لتنفيذ عقوبـة في دولة أخرى عن نفس الواقعة، بصرف النظر عما إذا كان ذلك الحكم صادراً بالبراءة أم بالإدانة. ويشترط لعدم إعادة تنفيذ هذا الحكم أن تكون العقوبة قد تم تنفيذها أو جاري تنفيذها، مالم تكن تلك الواقعة قد حصلت على عفو شامل، أو عفو عن عقوبتها، أو سقطت بالتقادم. 
وإذا كان المشرع يحصر القيود المانعة من تحريك الدعوى في حـالتي البراءة والإدانة المتبوعة بتنفيذ العقوبة، فإن ذلك يعنى استبعاد ما عداهما من الأسباب كتقادم اللدعوى أو العقوبـة طبقـا للقـانون الأجنبي أو صدور عفو شـامل أوعفو عن العقوبـة لمصلحة المتهم (') أو حفظ سلطات التحقيق للاعوى ()، فهذه الأسباب كافة لا تحول دون تحريك الدعوى الجنائية في مصر. فـلا ينبغي أن يقاس على ذلك الحفظ الذي يصدر به أمر أو قرار من سلطة التحقيق الأجنبية، حتى ولو كان هذا الحفظ قطعياً، لذا لا يكفي لمنع المحاكمة الحكم الجزئسي القابل للاستئناف ولا الاستئناف القابل للنقض. ومسن بـاب أولـي لا يكفي أمـر الحفظ ولا الأمسر بـأن لا وجـه لإقامـة الـدعوى ولـو كـان قطعيـا للحيلولـة دون إمكسان المحاكمـة عن نفس الجنايـة أو الجنحـة. كمــا أنـهـ لا محل للقياس في هذه الحالة مـادام الحفظ بعيداً عن معنى البراعة التي يصدر بها حكم من محكمة أجنبية، وفرق بين ما تصدره المحاكم من الأحكام ومـا تصدره سلطات التحقيق

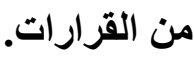

كما لا يجوز الاكتفاء بتنفيذ حكم الإدانة الصادر من المحكمة الأجنبية كليًاً أو جزئيـاً بحسب الظروف، بـل لابـا على أيـة حـال مـن إعـادة المحاكمـة أمسام المحساكم المصرية، وذلك لأن أثر مثل هذه الأحكام الأجنبية يقتصر على علي كونها مانعة من إقامة الدعوى أمام القضاء المصري إذا كانت نهائية واستوفي المجرم العقوبة المحكوم بها كاملة في حالة الإدانة.

(1) انظر تعليقات الحقاتية على المادة ؛ من قاتون العقوبات الصادر سنة ؛ ـ 9 ـ.

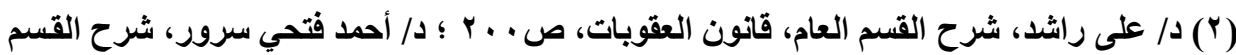

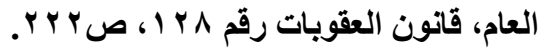


ونضيف هنا أن المشرع المصري لم يجعل لسقوط العقوبة ـ التي حكم بها في الخارج - بالتقادم أو لصدور العفو عنها الأثر المترتب على تنفيذها كاملة من حيث منع إعادة المحاكمة عن الجريمة أمام القضاء. وعلى العكس من ذلك أخذت الفقرة الثانية من المادة الرابعة عن المادة بـ 1 من القانون البلجيكي ما يجعل لسقوط العقوبة بمضي المدة وفقاً للقانون الأجنبي أو صدور عفو عنها نفس الأثر المترتب على تنفيذها من حيث عدم جواز إقامة الدعوى بعد ذلك. وقد رؤى عند وضع المادة الرابعة من القانون المصري حذف ما يختص بسقوط العقوبة بمضي المدة وبالعفو عنها، فلا تنقضي بهمـا السلطة في معاقبة المحكوم عليه في مصر ('). ولـم يـرد في المـادة الرابعة شـيء عن انقضاء الـدعوى العموميـة بالتقـادم أو صدور عفو عن الجريمة وفقاً للقانون الأجنبي. ومن ثم لا يصح قياس هذين السببين على تقـادم العقوبـة أو العفو عنهـا، لاختلاف الآثـار المترتبـة على كل منهمـا، فتقـادم

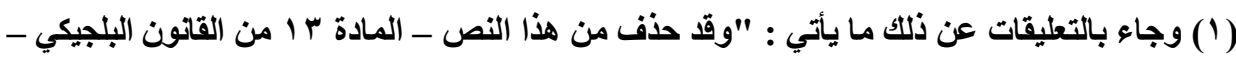

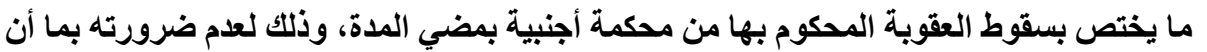

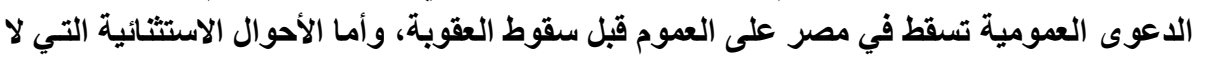

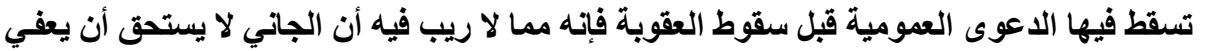

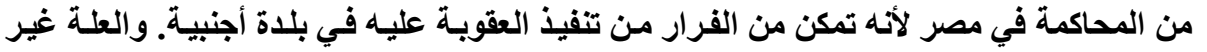

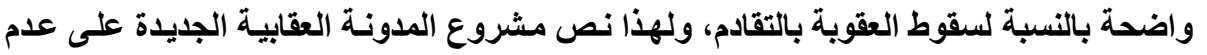

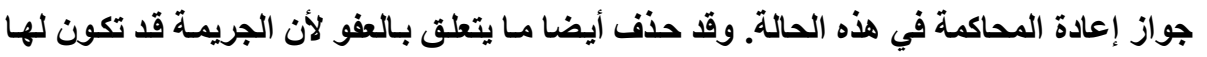

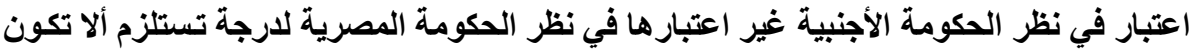

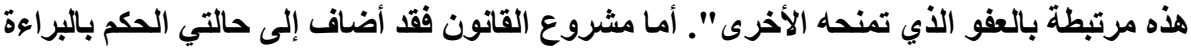

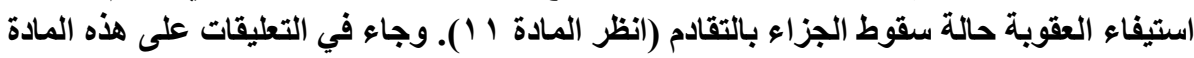

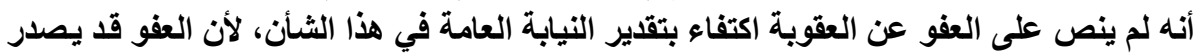
لأسباب سياسية أو شخصية لا تتفق مع شعور الجمهور بهاء. 
الاعوى أو العفو عن الجريمة يجعل الفعل غير معاقب عليه، فيحول دون المحاكمة عن الجرائم المشار إليها في المادة الثالثة ولا يمنع المحاكمة عن الجرائم المشار إليها في

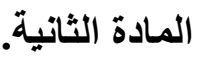

ولا يحـول العفو عـن العقوبـة أو عـن الجريمـة في البلــــ الأجنبـي مسن إعـادة

المحاكمة عن الجرائم الواردة في المـادتين الثانية والثالثة إذ يخضع العفو لاعتبارات سياسية قد تختلف من دولة إلى أخرى. وتعاد المحاكمة كذلك إذا كاتت العقوبة المقضي بها في الحكم الأجنبي قد سقطت بالتقادم ولم تكن قد سقطت في مصر الدعوى العمومية عن نفس الجريمة لكون الجريمة مثثلا جنايـة طبقـا لقانون مصر بينمـا هي جنحة طبقاً للقانون الأجنبي، أو إذا كاتت تلكا العقوبة قد صدر أمر بـالعفو عنها من رئيس الدولـة

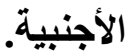
فالواقع أن المادة الرابعة من قانون العقوبات لم تذكر كمانع من إعادة المحاكمـة سوي استيفاء العقوبة بتففيذها الكامل، الأمر الذي يـل على أن المحاكمـة لا تمنـع في غير هذه الحالة أي في حالة تقـادم العقوبـة أو العفو عنها('). والراجح أنـه إذا تقادمت (1) وفي ذلكت خـالف قانون العقوبـات المصري القانون البلجيكي كمـا يستفاد من تعليقـات الحقانية

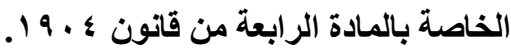

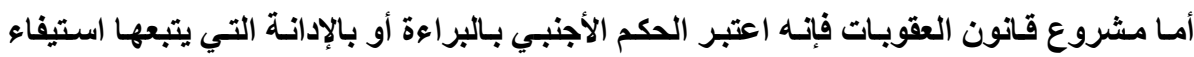

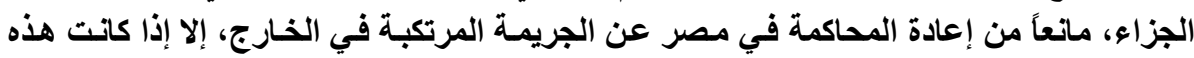

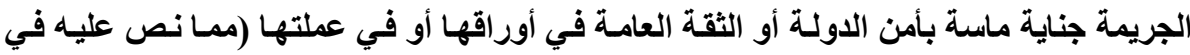

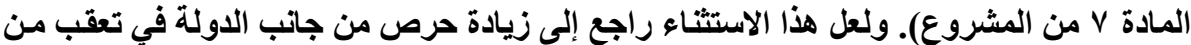

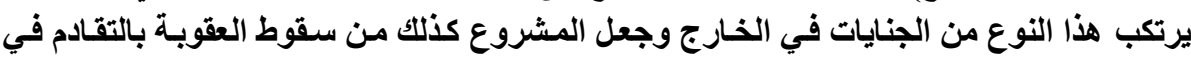

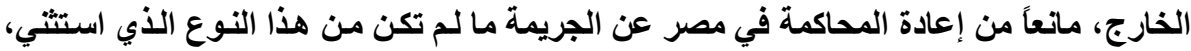
$=$ 
الـــعوى أو العقوبـة بحسب التشريع الأجنبـي فـلا حائسل يحـول دون المحاكمـة عـن الجريمة، ما لم تكن قد تقادمت وفق القانون المصري. فتقادم الجريمـة أو العفو الشامل

ذلكك ما قررته المادة 11 من المشروع بقولها :

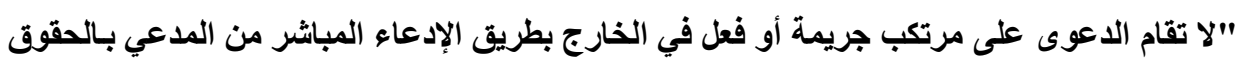

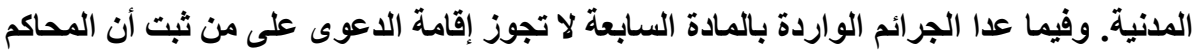

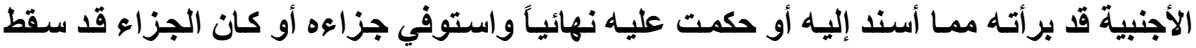

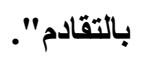

\section{وجاء في المذكرة الإيضاحية لهذه المادة بالمشروع الأصلي:}

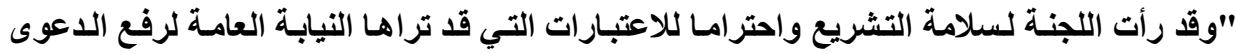

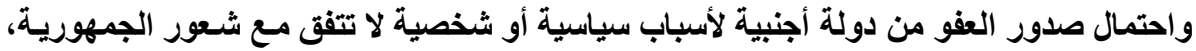

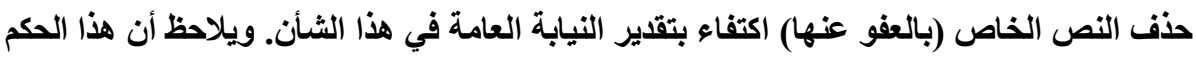

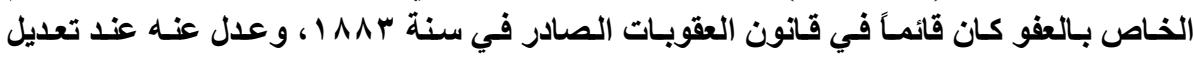

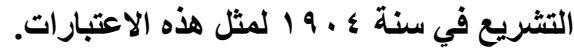

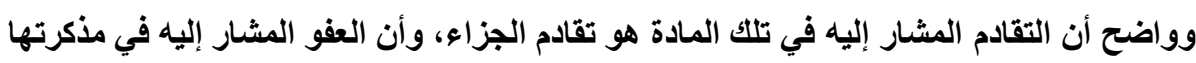

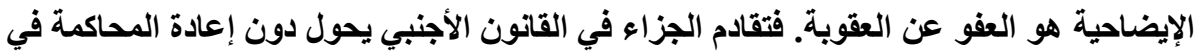

مصر، بينما لا ينتج هذا الأثر العفو عن الجزية فئواءو الجزاء

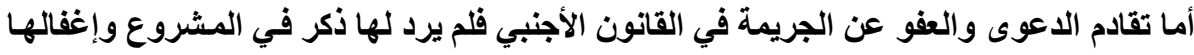

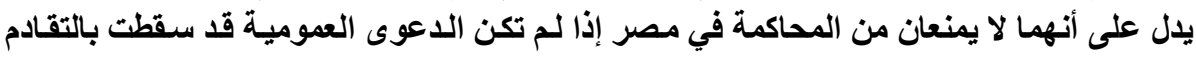

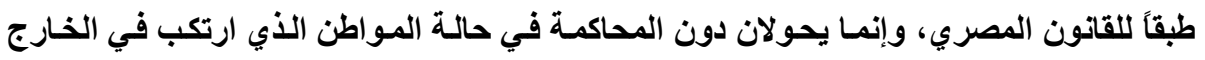

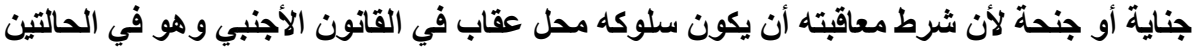

$$
\text { المذكورتين يصبح غير معاقب عليه. }
$$

على أن المشروع استحدث حكماً جديد يقضي بأنه في حالة المحاكمة أمام القضاء الوطني إمباء إمـا لأن

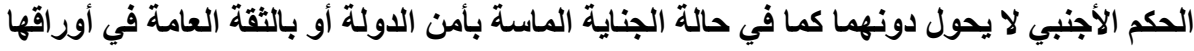

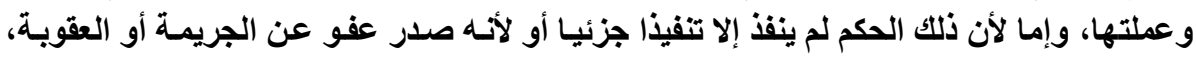

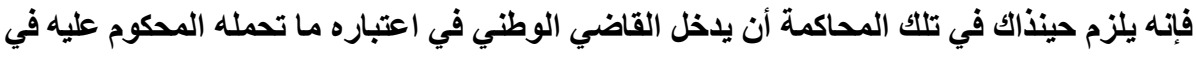
الخارج من عقوبة أو من حبس احتياطي".

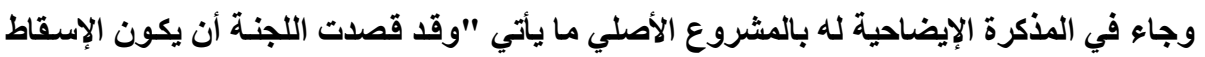
إلزاميا وأن يعهد به للقاضي توقيا من تحكم السلطة التتفيذية أو سهو ها". 
إذا تم وفقا للقانون الأجنبي فإنه يجعل الفعل غير معاقب عليه بما يؤدي إلى عدم إمكان محاكمة المصري الذي يعود بعد ذلك إلى مصر. أمـا تقادم العقوبـة أو العفو عنها فلا يحول دون إعادة تلك المحاكمة.

أما إذا سقطت اللدعوى العمومية عن الجريمـة طبقاً للقانون الأجنبي أو صدر عفو عن هذه الجريمـة هنـاك، فإنها في الحـالتين يصبح السلوك غير معاقب عليه، ولا يمكن بالتالي إجراء المحاكمـة عنـه في مصر إن كـان منسوباً إلى مصري، وبالتـالي لا محل لمعاقبة المصري لعدم حيث العقاب عن سلوكه طبقاً للقانون الأجنبي، وإنمـا تقام الدعوى في حالة الجريمة المنفذة ولو جزئياً بـإقليم الدولـة، وفي حالة الجنايـة المخلة بأمن الدولة أو بأوراقها أو بعملتها، وذلك إذا كاتت الدعوى لم تسقط بعد بالتقادم طبقاً للقانون المصري.

ويضاف إلي ذلك أن ظاهر النص يفيد أن المشرع لا يستلزم الحكم النهائي إلا في حالة الإدانة، غير أن المقصود هو الحكم النهائي في الحالتين. ومن جهة أخرى جاء

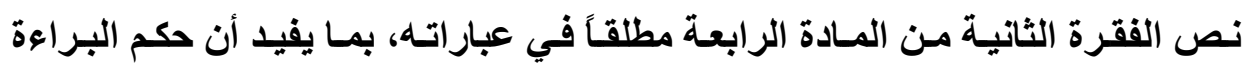
الصادر من المحاكم الأجنبية لا يكون مانعاً من إقامة الدعوى الجنائية إلا إذا كان سبب لهب البراعة هو عدم ثبوت الواقعة لا عدم التجريم عبر استثناء جرائم المادة الثانية من القيد الثاني كله، بمعنى أن الحكم الصادر من المحاكم الأجنبية في الجرائم المذكورة، سواء أكان بالبراءة أم بالإدانة، يمنع من جواز إقامة الدعوى ثانية في مصر. لذلك نوصي بعدم الاعتداد بأحكام البراعة الصادرة من المحاكم الأجنبية استنادا إلى أن القانون الذي تطبقه لا يعاقب على الفعل إذا كانت محاكمة المتهم بناء على المادة الثانية من قانون العقوبات على سند من أن نصوص القانون يجب أن تفسر على أنها 
كل لا يتجزأ، ممـا يتعين معه عند تحديد المقصود بحكم البراءة الاستعانة بمـا تقرره المادة الثانية من قانون العقوبات وتخصيص حكم البراءة بالنسبة لهذه المـادة باستبعاد البراءة لعدم وجود نص في القانون الأجنبي.

وإذا كان الحكم صادرا بالإدانة، فِان المشرع يتطلب استيفاء المحكوم عليه كل عقوبته، ويعنى ذلك أنها إذا لم تنفذ فيه العقوبـة أو لم ينفذ فيه سوى جزء منها فلا يتحقق القيد. واشترط التتفيذ الكامل للعقوبـة هو استثناء من القواعد العامـة في قوة الشيء المحكوم فيـه، إذ الأصسل أن ينسب انقضاء الـدعوى إلـى الحكم ذاتـه، لا إلى تنفيذه(')، ولكن يفسر خطة الشـارع حرصه على ألا يفر الجـاني من العقـاب لمجرد أنـه أدين طالما أن العقوبة لم تنفذ فيه. ويتحقق القيد بالتتفيذ الكلي للعقوبة، ولو كان وصف الجريمـة في القـانون الأجنبي أقل خطورة مـن وصفها في القـانون المصري وكانت العقوبة التي قضي بها الحكم الأجنبي تافهة بالقياس إلى مـا كـان يتحمل أن يقضي بـه على المتهم تطبيقاً للقانون المصري.

\section{جواز الماكمة البديدة عن نفس الجريمة (الاختصاص العيني والاقليهي)}

يستبعد الاختصاص العيني قاعدة عدم جواز محاكمة الشخص مرتين عن نفس

الجرم من نطاق التطبيق، حيث يسمح للاولة صاحبة الاختصاص العيني بإعادة محاكمة الجـاني مرة ثانيـة، إذا مـا كاتـ الواقعة المرتكبة ممـا يشملها مبدأ العينيـة، وبـرف النظر عما إذا كان الجاني قد سبق الحكم عليه ونفد عقوبته بالخـارج أم لا، وذلك نظراً لخطورة تلكك الجرائم التي يتضمنها مبدأ العينية، ولحرص الدولة التي انتهكت تلك

(1) Donnodieu de Vabres, no. 1703, p. 954. 
الجريمة سيادتها، على القصاص بنفسها لهذه الجريمة التي تمس بالدرجة الأولي أمنها

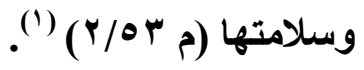

وكذلك الحسال فبان تلكك القاعدة تستبعد من مجال التطبيق في حالة اختصاص

دولة محل ارتكـاب الفعل الإجرامسي بالمحاكمة طبقاً لمبدأ الإقليمية، مـا لم ترفض تلك في الدولة المحاكمة عن هذا الفعل (م r ه). ويثير ذلك مشكلة وجود تتـازع في التطبيق الداخلي لمبدأ الإقليمية، حيث أن التشريع الداخلي للدول لم يحدد - بطريقة دقيقة ـ الوقائع المرتكبة التي تمت على إقليمـه من عدمـه طبقاً للمبـادئ الأسـاسية في تحديد الاختصاص الجنائي الدولي (الإقليمية ـ العينية ـ الثخصية ـ العالمية)، ولا يجب على الدول أن تتلـل طالما أن هناتك اختصاص أصيل لاولة أخرى، مـا لم تتنـازل تلكك الدولية عن حقها في ممارسته، وحتى لا يؤدي ذلك لمعارضة القاعدة.

إلا أن المادة ؛ه من تلكت الاتفاقية قد بينت حالة ما إذا بدأ في المحاكمة الجنائية ضد الشخص المحكوم عليه، وقضي مدة سـالبة للحريـة تبعاً لها، فِان المحاكمـة توقف وتخصم العقوبة التي قضاها الجاني من حكم الإدانة الصادر عليه والواجب النفاذ.

فهذه الاتفاقية تقبل الأثر غير المباشر الأساسي، فيمـا يتعلق بالعقوبـات السالبة للحرية التي قضاها المحكوم عليه بالخـارج، ومـع ذللك فإنـه ليس من الكلازم أن تخصم مدة الحبس الاحتيـاطي التي سبق أن قضاها بالخـارج. ولا يقبل القول بعدم جدوى أو تأثير مدة العقوبة التي قضاها المحكوم عليه قبل الحكم نظراً لأن العبرة بالتنفيذ الفعلي

(1) SAUER, W. : Le problème de l'unification des peines et des mesures de surte, in R.I.D.P. 1953, PP. 601 et. ss. 
للعقوبة، فمادام الجاني قد نفذ عقوبته بأي شكل، أو بأيسة صورة ، سواء قبل صدور الحكم أو بعده، فهو في النهاية قد نفذ العقوبة.

ومما لا شكك فيه أن ذلك الخصم هو إجراء منطقي وعادل في تلك الاتفاقية بل أن تنفيذ العقوبة تحت اصطلاح الحبس الاحتياطي قبل صدور الحكم النهائي، يعد إهدار لحق الجاني، حيث نفذت عليه عقوبة بطريق غير مباثر دون صدور حم نهائي عليه، كما أنه لو صدر عليه حكم بالبراءة، فسيولا ذلك لايه نوعا من رد الفعل المعاكس ضد

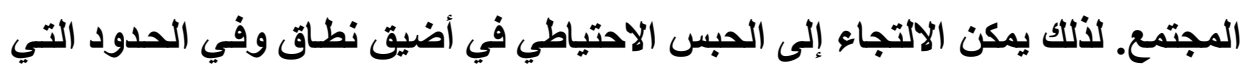
تستلزمها طبيعة التحقيق.

وفيما يتعلق بثروط الاعتداد بالحكم الجنائي الأجنبي نصت المـادة $ه 0$ من تلكك

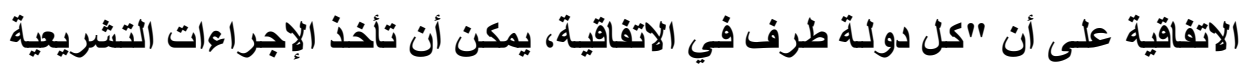
المناسبة، بهاف السماح لمحاكمها باصدار حكم يأخذ في اعتباره، كل الأحكام الجنائية



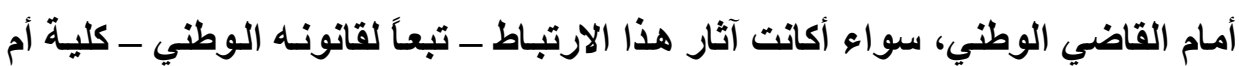

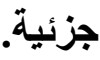

ومن جماع ما سبق يمكن القول أن الاتفاقيات الأوربية في المجال الجنائي لعبت

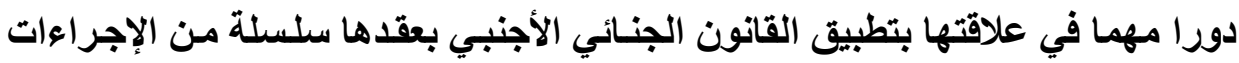

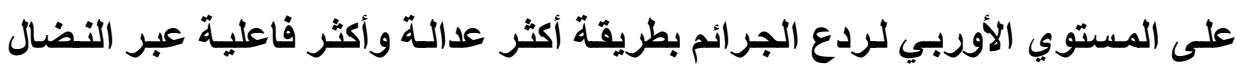
المستمر ضد الإجرام والمجرمين الذين يمتد نثاطهم فيما وراء حدود الدول، ويتمكنون من الهرب بأقصى سرعة إلى تلك الأماكن التي قد تجعلهم بمنأى عن يد العدالة. فظهور

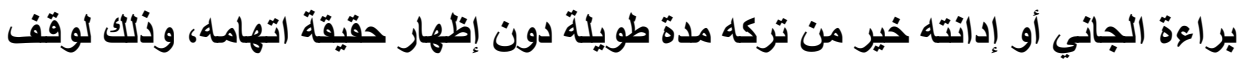


أسهم الاتهام الموجه إليه. كما أن تحويل المحاكمـات لدولة أخرى لـم تقع على أرضها الجريمـة لكي تطبق قانونهـا، يعد في حقيقة الأمـر تطبيقاً للقـانون الجنـائي الأجنبـي. والأصـوب أن يطبق قـانون محل ارتكـاب الفعل الإجرامـي دون النظر لقـانون الدولــة المطلوب منها اتخاذ إجراءات المحاكمة أو التنفيذ. 


\section{المبحث الثالث}

صور تطبيق القاضي الجنائي للقانون الأجنبي

قد يتطلب القاضي الوطني توافر عدة شروط - خاصة في المسائل ذات العنصر الأجنبي - للقيام بتطبيق القانون الأجنبي، فقد يقوم أحد الأطراف بإثارة تطبيق القانون الأجنبي لدولة ما، لحم المشكلة محل النزاع. وقد توقف الحكم في هذه الدعوى على

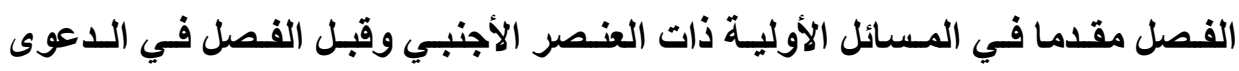

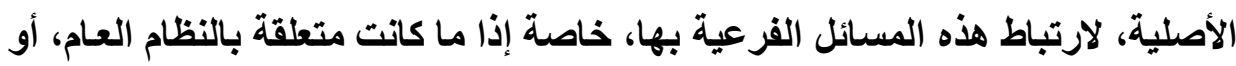
بالغش نحو القانون، أو المصلحة العامة'(')

فالقاضي الجنائي الوطني يطبق القانون الأجنبي فيما يتعلق بتكييف الجريمة أو

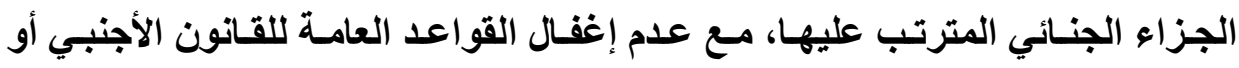
تكييف الجريمة فقط، مع تطبيق الجزاء المنصوص عليه في القانون الوطني أو يتوقف

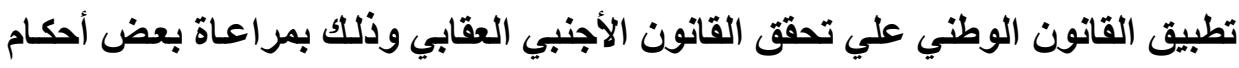
القانون الأجنبي عند تطبيقه للقانون الوطني، وذلك كمر اعاة الثروط الخاصة بازدواج التجريم في القانونين الوطني والأجنبي. ويجب على القاضي أن يقوم بالبحث في مضمون القانون الأجنبي للتأكد من التكييف السليم للواقعة طبقًا للقانون الأجنبي، وليس طبقًا لقانونه الوطني، فتطبيق القانون الجنائي الوطني متوقف على تحقيق الاختصاص أو تكيف الواقعة طبقاً للقانون ( (1) د أحمد فتحى سرور، الوسيط في قانون العقوبات، مرجع سابق، ص هبr. 
الأجنبي. وقد يثار أمام القاضي الوطني الجنائي أثناء نظره لنزاع ذي صفة جنائية، دفع ذو صفة غير جنائية، ولكن يترتب على الفصل في هذا الدفع الحكم في الواقعة الأصلية؛ حيث يشترط لتوافر أحـا الأركـان الأسـاسية للجريمـة، أن تحقق قاعدة غير عقابيـة منصوص عليها في القانون الأجنبي كتسليم مال منقول إلى الغير بنـاء على أحد عقود

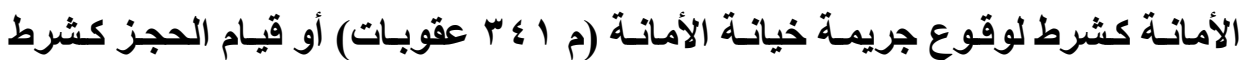

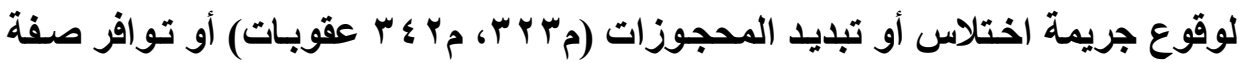
الموظف العـام كشرط فيمن يرتكب جريمـة الرشـوة (م ب ـ ا ومـا بعدها عقوبـات) أو وجود عقد زواج صحيح كثرط مفترض لقيام جريمة الزنا (rVT وما بعدها عقوبات). وحول أثر الثرط المفترض في تطبيق القانون الأجنبي ميز الفقه المعاصر بين

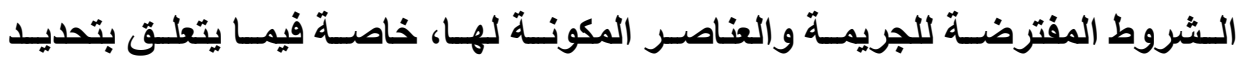
الاختصاص، وطرق الإثبـات؛ حيث يتحدد الاختصاص الإقليمسي للسلطات والمحساكم الجنائية طبقاً للمكـان الذي وقعت عليه الجريمـة وتحققت عليه العناصر المكونـة لها، دون النظر إلى مكان تحقق شرطها المفترض، فجريمة خيانة الأمانـة لا تعد مرتكبة في المكان الذي أبرم فيه العقد، وإنما تعد مرتكبة على الإقليم الذي تم فيه تسليم الأشياء الذي يعد أحد العناصر المكونـة للجريمـة، وفي حالة وقوع الاختلاس من موظف عام بناء على عقد تم بالخارج، فالقانون الأجنبي هنا هو الأي يحكم مدي صحة هذا العقد، ويترتب على الفصل فيه، تحديد المسئولية الجنائية للجريمـة التي وقعت بالخـارج من عدمـه. وكذلك الحسال بالنسبة لجريمـة إصـدار شـيك بـدون رصـيد بالخـارج، فالقـانون الأجنبي الأي يحكم إصدار الشيك هو الذي يحدد مدي صحته. فالقانون الأجنبي غير 
العقابي يتدخل دائما لحكم العلاقة القانونية ذات الطابع العقابي، بناء على قواعد الإسناد الوطنية (')

أمساطرق الإثبات فتنص المـادة ه Y r من قانون الإجراعات الجنائية على أنـه "تتبع المحساكم الجنائيـة في المسال غير الجنائيـة التي تفصل فيهـا ـ تبعـاً للـدعوى الجنائية ـ طرق الإثبات المقررة في القانون الخاص بتلك المسائل، وهو مـا نص عليه

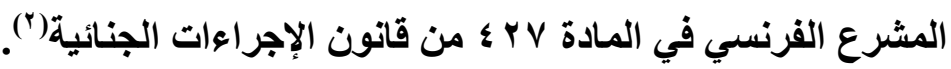
فإثبـات عقد الأمانـة الذي تم التسليم بنـاء عليه، يخضع للقواعد المقررة في القـانون المــني، ذلــك أن إثبـات المسـائل الأوليـة غيـر الجنائيـة اللازمـة للفـصل في الدعوى، وإن اختص القاضي الجنـائي بالفصل فيها، إلا أنها مقيد في إثباتها بالقواعد المقررة في قوانينها. إلا أن قانون العقوبات قد يوسـع أو يضيق الحمايـة التي يضفيها

(1) DECOCQ, A. : La structure de la qualification legale, cours de droit penal approfondi, Universite du Caire 1968-1969, pp. 1 et. ss. Commissions rogatoires internationales en matiere penale, Jur. Cl. Dr. Pen. Int, Art. 151 a 155 du C.P.P.Fasc, 405, A, (2 Cahier), 3, 1982, No. 1, p. 2 et.ss.

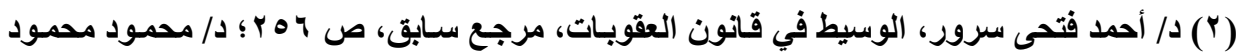

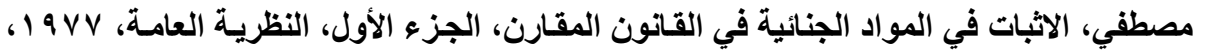

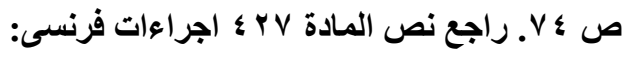

Article 427: Hors les cas où la loi en dispose autrement, les infractions peuvent être établies par tout mode de preuve et le juge décide d'après son intime conviction. Le juge ne peut fonder sa décision que sur des preuves qui lui sont apportées au cours des débats et contradictoirement discutées devant lui. Modifié par Loi 93-1013 1993-08-24 art. 28 JORF 25 août 1993 en vigueur le 2 septembre 1993 
القانون غير العقابي للشرط المفترض، ومثال ذلك، إضفاء الحماية الكاملة لقوة الشيك الذي صدر دون رصيد، ففي حالة بطلانهـ لعدم وضوحه طبقاً لقواعد القـانون المدني، فإن ذلك لا يحول دون وجوب العقاب على جريمة إصدار الشيك بدون رصيد. سلطة القاضي الجنائي في تطبيق القانون الأجنببي غير العقابي توجب احترام القواعد الخاصة بتنازع القوانين واختلاف منـاهج التشريعات أن يلتزم القاضي الجنائى بتطبيق القوانين الوطنية أو الأجنبية دون توقف ذلك علي محض اختيار أو تفضيل من القاضي علي الاعتراف للأخير بحقه في امتداد سلطته في تطبيق القوانين الأجنبية رغم ما يثيره تطبيقها من عقبات عملية.

فالمـادة ب ج ج مـن قـانون الاجـراعات المدنيـة الألمانيـة تقرر الطبيعة القانونيـة للقانون الأجنبي عند تطبيقه أمسام القضاء الوطني دون اعتباره واقعة تتعلق باثباته، ومن ثم يجب اثارته من قبل الأطراف حتى يمكن تطبيقه وبالتالي يجب على القاضي أن يطبقه من تلقاء نفسه، بل أن المحكمة العليا لها أن تراقب تطبيق القانون الأجنبي كمـا في حالة الرقابة على قوانينها الداخلية، ويلتزم القاضي الجنائي بتطبيق القانون الواجب التطبيق بمقتضي قواعد التنازع الألمانية حتى ولو لم يثره الأطراف. فهناك مساواة في المعاملة الإجرائية بين القانونين وتراقب المحكمة العليا محكمة الموضوع في إعطائها التفسير الصحيح للقانون الألماني الوطني و إلا كان حكمها معرضا للنقض ('). وعلي خلاف ذلك يعتبر القضاء الاتجليزي والأمريكي القانون الأجنبي واقعة يقع علي الأطر اف اثارته واثباته، فقي دعوى Cooper اعتبر القضاء الإنجليزي القـانون

(1) DAVID, CY. : La loi etrangere devant le juge du fond, etude comparative, Dalloz, Paris 1964, P.26. 
الأجنبي بمثابة واقعة. وتتلخص هذه الدعوى في أن إحدى الزوجـات كانت قد عقدت زواجها في أيرلندا، أثنـاء إقامتها بها، بمقتضي القانون الايرلندي الذي كان يعتبرهـا قاصرة لعدم بلوغها سن الرشد، وبالتالي فإن زواجها يعتبر باطلاً لعدم أهليتها، فأقامت الزوجـة دعوى أمسام المحسكم الاسكتلندية لإبطـال عقد زواجهـا، التـي طبقت القـانون الاسكتلندي، حيث أن الزوجة لم تثر تطبيق القانون الايرلندي، واعتبرت عقد زواجها صحيحاً، إلا أن الزوجة طعنت في هذا الحكم أمام غرفة اللوردات، وأعلنت رغبتها في تطبيق القانون الايرلندي لأمر مرة، فرحبت غرفة اللوردات بذلك لمعرفتها جيداً بهذا القـانون، حيـث اعتبرتـه مـن الوقـائع المشهورة والشـائعة، وأعلنـت أن زواجهـا كـان

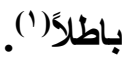

كما أن ولاية نيويورك تسمح للقاضي بالبحث في قوانين البلاد الأجنبية والتي تعتبر القانون الأجنبي واقعة، وبالتالي لا يجوز للقاضسي تطبيقه من تلقاء نفسه مـا لم يثره الأطراف، حتى لا يفاجأ الخصوم بتطبيق القانون الأجنبي الذي لم يتوقعوه، وعلى القاضي أن يعلن الأطراف بالقانون الواجب التطبيق، سواء أكان أجنبياً أم وطنياً، وهو بذلك سوف يتجنب عنصر المفاجأة(؟). فالقضاء الإنجليزي والأمريكي قد اعتبر القانون الأجنبي بمثابة "واقعة"، حتى لا تحـدث مفاجـآت للخـصوم مـن جـراء تطبيـق القـانون الأجنبـي إذا اعتبره مسسالة "قانون"، مما يؤدي إلى إعفائه من عبء إثباته وتفسيره ورقابته.

(1) DAVID, CY. : Thèse. Prec. P. 30.

(2) DAVID, CY. : Thèse. Prec. P. 27. 
وفي هذا اتجهـ الفقهـ الغالب الفرنسي إلى أن القانون الأجنبي يحتفظ بطبيعته الأصلية كقانون، عند تطبيقه أمام القضاء الوطني، حيث لا يعتبر عنصراً من عناصر الواقع. وحجتهم في ذلك أن القانون الأجنبي لا يندمج في القانون الوطني، بل يحتفظ بصفته الأجنبية، وهو يسري بوصفه أمراً صـادراً من المشرع الأجنبي، بنـاء على لهـ تفويض أو إنابة من المشرع الوطني، ويستمد عنصر الإلزام من مشرع الدولة الأجنبية التي أصدرته بناء على تفويض أو إنابة من المشرع الوطني ('). ويترتب على الأخذ بفكرة التفويض أو الإنابة، تأكيد الطبيعة القانونية للقانون الأجنبي، مع الاعتراف بصفته الأجنبية في نفس الوقت، ومن ثم يلتزم القاضي الوطني بتطبيقه من تلقاء نفسه.

إلا أن هذا التبرير لموقف الفقه الغالب في فرنسا بشأن معاملته للقانون الأجنبي

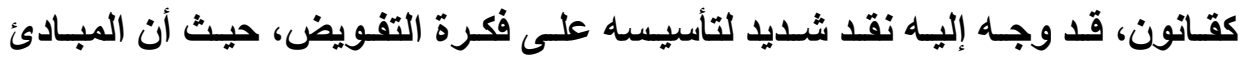
الاستورية العامة تحول دون تفويض المشرع الوطني لسلطة تشريعية أجنبية بالقيام بالتشريع بـلا منـه، فضلاً عن أنه من مغير المقبول أن يقوم المشرع الوطني بإنابـة مشرع أجنبي غير معروف مقدماً، ويختلف باختلاف المسألة المطروحة على القاضس، ثم أن الإنابة أو التفويض من جاتب المشرع الوطني تفترض رضـا المشرع الأجنبي

(1) MOTULSKY, H. : L'office du juge et la loi étrangère Mélanges offerts a jacques MAURY, T. I, Paris, 1960, pp. 360 et. ss. 
بذلك، في حين أن المشرع الأجنبي المفوض في التثريع، قد يقوم بأعمال الإنابة دون

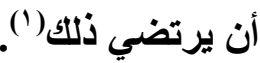

أمسا الفقه المصري فيري جاتب منـه ضرورة الإبقـاء على الطبيعة القانونيـة والأجنبية للقانون الأجنبي الواجب التطبيق، حيث أنه لا نزاع في طبيعته القانونية، لأن قاعدة الإسناد الوطنية التي توجب تطبيقه لا تنصرف إلى غير القانون، كما أنه لا نزاع في طبيعته الأجنبية بحكم السلطة التي أصدرته، ويترتب على الطبعة القانونية للقانون الأجنبي، التزام القاضي بالعمل على الكثف عن مضمونه، وعليه إثباته بجميع الطرق، بما فيها كتب الفقه وأحكام القضاء(") وقد أيدت محكمة النقض الفقه المصري الغالب، وأخذت بالمساواة بين القوانين الوطنية والأجنبية على حد سواءو، فاعتبرت تطبيق

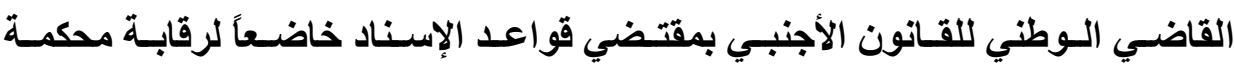
النقض(")

\section{حالات وجوب تطبيـق القـانون الجنسائي الأجنبـي رغسم وقـهوع الجريمسة داخلـ}

الاقليم:

قد يكون في بعض الأحوال القانون الجنائي الأجنبي هو القانون الطبيعي الذي

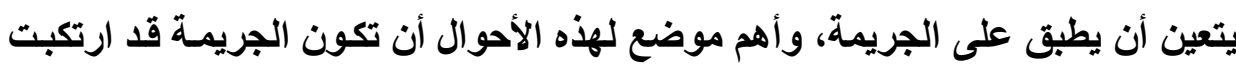

(1) راجع في تطور القضاء الفرنسى في اعتبار القانون الأجنبي واقعة أم قانون د/ عبد الله اليعقوبي،

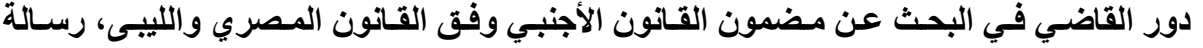

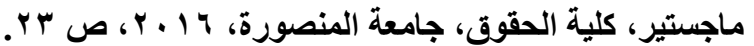

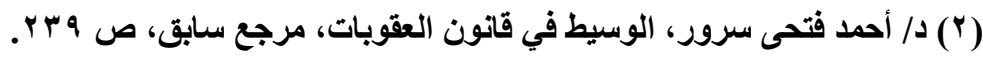

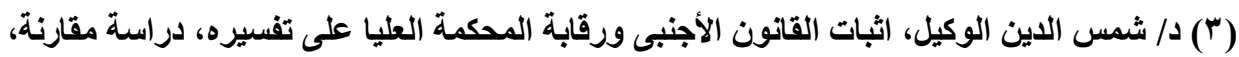

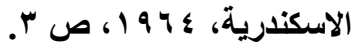


خارج الإقليم، إذ يكون القانون الساري في الإقليم الذي ارتكبت فيه هو قانونها الطبيعي باعتبارها قد نالته بالاعتداء وأهدرث حقوقا يحميها، ثم أنه القـانون الذي توقع المتهم أن يطبق عليه. وإلي جاتب ذلكك توجد حالات أخرى ترتكب الجريمـة فيها داخل الإقليم ويكون تطبيق القانون الأجنبي عليها واجبا، وأهم هذه الحالات :

الأولي أن يكون توافر أحد أركان الجريمـة مقتضيا تطبيق قواعد غير جنائية، فيكون الرجوع إلى القانون الأجنبي لتحديد هذه القواعد متعينـا طبقا للقـانون الدولي الخاص، مثال ذلك أن يتهم أجنبي بالزنـا، ويتعين التحقق من قيام الزوجية باعتبارهـا ركنا في هذه الجريمة فيكون محتمـا الرجوع إلى القـانون الأجنبي الذي يحكم الأحوال

الشخصية للمتهم للفصل في قيام الزوجية والتحقق من توافر أحد أركان الجريمة('). حين يعرض على القانون الوطني مسألة ذات عنصر أجنبي يتنازع حكمها أكثر من قانون، يتولي القانون الدولي الخاص تحديد أنسبها لكي يطبق على هذه المسألة أو على بعض جوانبها. فقواعد الإسناد أو التنازع التي يضمها القانون الدولي الخاص هي قواعد تهرف إلى التنسيق بين القوانين الوطنية والأجنبية أو الأجنبية فيمـا بينها حال

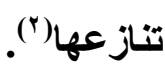

(1) Donnedieu de Vabres, no. 1677, p. 944; Zlataric, no. 157, p. 299.

(2) BATIFFOL et LAGARDE : Droit International prive, 7e ed. T.I, 1981, L.E.D.J, No. 246, p. 292, No, 247, p. 293.

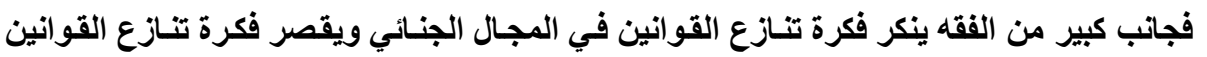

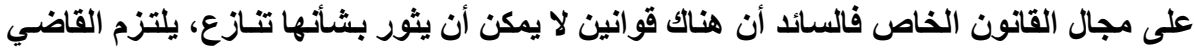

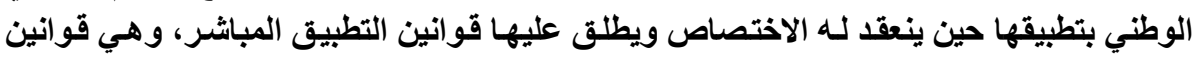

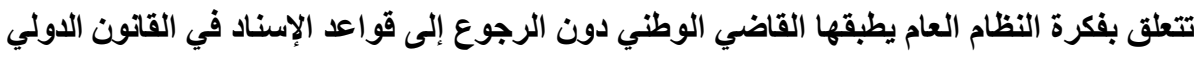
الخاص. ولا تختلط فكرة تنازع القوانين بفكرة نطاق تطبيق القانون من حيث المكان، فحل مشكلة الفئ

$=$ 
فالاختصاص التشريعي والاختصـاص القضشائي فـي المجـال الجنـائي أمـران مندمجان(') بعكس الحال في القانون الخاص حيث يتصور افتراقهما. لذلك يحدد القانون الجنائي الوطني الجرائم التي تخضع لله وتلذخل في اختصاص المحسكم الوطنية ولا يعبـأ

تنازع القوانين لا يعنى فقط تحليد نطاق تطبيق القانون الوطني، ولكن أيضا تحديد أي قانون ينبغي

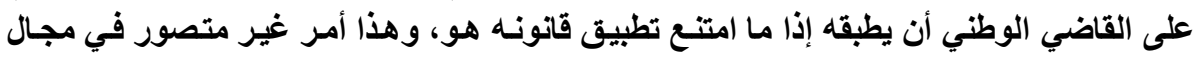

$$
\text { القانون الجنائي أنظر : الوطي أن }
$$

LEVASSEUR et DECOCQ : Confilits de lois (matiere penale) Repetoire de droit International T.I. Dalloz 1968, No. 5. p. 498.\& DECOCQ André, la structure de la qualification légale- cours de droit penal approfondi, université du caire 1968-1969, droit penal général, librairie armand colin, 1971, P.97.

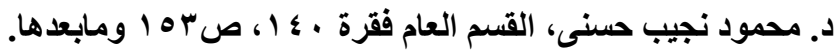

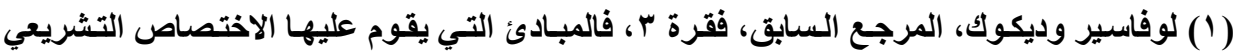
والاختصاص القضائي واحدة. وانظر أيضا:

DONNEDIEU DE VABRE : Les principes modernes de droit penal international, sirey, paris, 1928, p. 171.

مع ملاحظة أن دوندييه دي فابر يري إمكان افتراق الاختصاص التشريعي والاختصاص القضائي

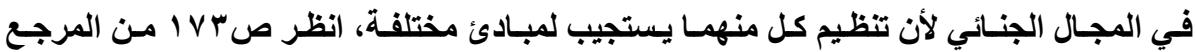

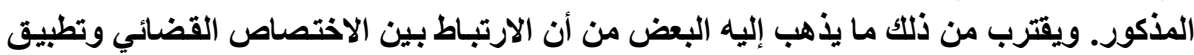

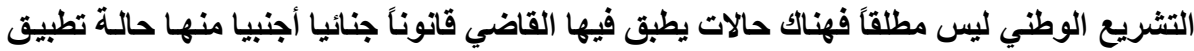

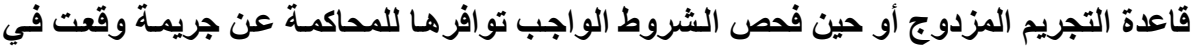

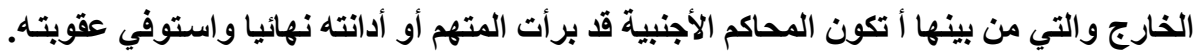

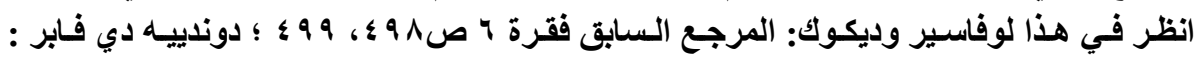

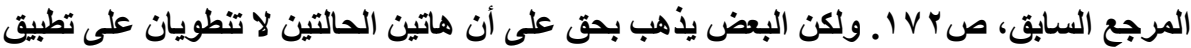

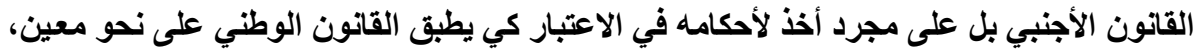

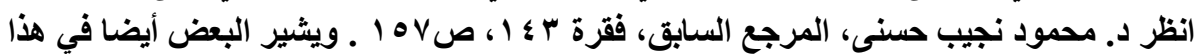

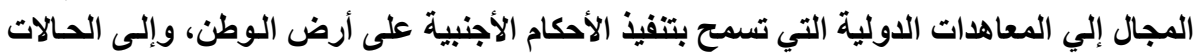
التي يأخذ فيها القاضي الوطني القانون الجنائي الأجنبي في اعتباره. 
بالقانون الأي يطبق على الجرائم التي لا تلخل في اختصاصه. فحين تكون هذه المحساكم مختصة فإنها لا تملك أن تطبق قانوناً جنائيا غير القانون الجنائي الوطني ('). ولما كان البنيان القانوني للجريمة يضم مراكز قانونية تثقرر أصلا في قوانين غير جنائية في غالب الأحوال، فإنـه مـن المتصور أن تتوافر حالـة من حـالات تنـازع القوانين بشأن المركز القانوني إذا ما ضم عنصرا أجنبياً. وهنـا يكون من المتصور أن يطبق القاضي الجنائي الوطني قانونـاً أجنبيا غير جنائي تحيله إلى قاعدة التنازع في

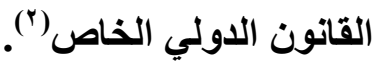

\section{- تطبيق القاضي الجنائب لقانون أجنببي غير جنائي :}

قد يتعرض القاضي الجنائي الوطني لحالات يطبق فيها قانون أجنبي غير جنائي عبر فكرة الثروط المفترضة في الجريمة. فيثور التساؤل عما إذا كان المركز القانوني المقابل للثرط المفترض في الجريمة يندمج في القاعدة الجنائية التي تحميه ويصبح جزعا منها بحيث لا يثور بشأنه تنازع في القوانين أم أنه يحتفظ بذاتيته الأصلية ويظل خاضعا للفرع القانوني الذي ينظمه وبالتالي يكون متصوراً أن يثور بشأنه تنازع في

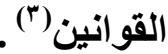

$$
\text { (1 ) لوفاسير وديكوك : المرجع السابق، فقرة } 7 \text { ، ص1 9 ؛ ؛ }
$$

(2) RAMSES BEHNAM: L'application par le juge national d'une loi penale etrangere - Rapport presente au Ville Congres international de droit penal - lisbonne 21-27 sept. 1961. Rev. Inter. Dr. Pen. 1962. No. 2p. 317 319.

(T) و على هذا المعنى يفهم قول البعض أن القاضسي الجنـاني الـوطني في هذه الحالـة يكون أمسام

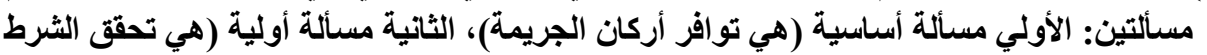
المفترض) ولكل مسألة قانونها الذي يحكمها أنظر في هذا الثأن: $=$ 
ففي جريمة إصدار الثيك بدون رصيد التي تحمي المبادئ المقررة في القانون

التجـاري المتعلق بالشيك. فرغم التوحيد الذي جري عن طريـق اتفاقية جنيف (19 مارس اسب ( ) (") مازال هناك نقاط اختلاف بين التشريعات الأمر الذي يجعل لتنـازع القوانين فيما يتعلق بالقانون الواجب التطبيق على الثيك أهمية كبيرة(؟). ويلزم في هذا السياق التفرقة بين الأحكام الجنائية في جريمة الشيك والأحكام غير الجنائية التي تحكم الثرط المفترض فيها وهو المركز القانوني الأي تحميه القاعدة الجنائية. فقيما يتعلق بالأحكام الجنائية فإن قانون مكان الارتكاب هو الذي يحكمها ولقد اتجـه القضاء الفرنسـي إلى أن اتفاقيـة جنيف لا تخـل بهـذا المبـدأ نظراً لأنهـا عنيـ بالدرجة الأولي بتنظيم القواعد المدنية والتجارية التي تحكم الثيك، وأن أحكامها بعيدة عن تنازع القوانين بثأن الأحكام الجنائية("). فقانون العقوبات الوطني هو الذي يطبقه القاضي من حيث مبدأ التجريم ونوع وقدر العقاب دون التفـات إلى كون إصدار الشيك بدون رصيد غير مجرم وفقا لقانون آخر (؛).

LAGARDE paul : la regle de conflit applicable aux question prealables. Rev. Crit dr. Inter. Pri. 1960, p. 460.

(1) Convention de Geneve portent loi uniforme sur les cheques. D.F. 89364-286.

(2) LEVASSEUR et DECOCO: Cheque droit penal Repertoire de droit International, T.I. Dalloz, 1968, No. 9 p. 309.

(3) Tirb. Corr. Seine: 13oct 1965, Gaz, pal, 1966-1-109; Rev. crit. Dr. inter. Priv. 1966 p. 499, note DECOCQ, R.S. C. 1966, 351, note Bouzat.

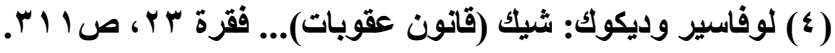

LAGARDE PAUL, LA règle de conflit applicable aux questions préables,Rev.crit.dr.inter.privé, 1960,P.462. 
أما فيما يتعلق بالأحكام غير الجنائية في جريمة إصدار الثيك بدون رصيد، فبان

السائد أن عدم قانونية الفعل وفقا للقانون التجاري الفرنسي لا يكفي لقيـام الجريمـة إلا إذا كان الفعل غير قانوني أيضا وفقا للقانون التجاري المختص وهو قانون مكان دفع مقابل الشيك(')

ففي دعوى تتلخص وقائعها في أن متهمـاً كـان قد سحب شيكا على بنك في نيويورك دفع التهمة بأن قانون ولاية نيويورك يسمح باشتر اط أن يكون الدفع خلال مدة

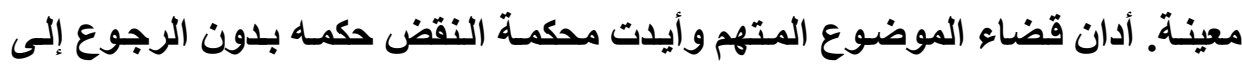
القانون التجاري الفرنسي الذي يحظر مثل هذا الإجراء مقررة أنـهـه وفقا لقـانون ولايـة نيويورك المختص بحسبانه قانون مكان الدفع، فإن الشيك يكون مقبول الدفع فوراً إذا لم تثقرر مدة المهلة كما هو الحال في الاعوى المعروضة'(ب). وتتحدد حقوق المستفيد على الرصيد وفقا لقانون البلا الذي ينبغي أن توفي فيه

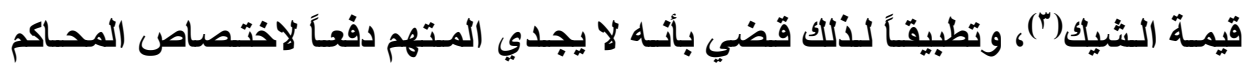
الفرنسية بجريمة إصدار شيك بدون رصيد القول بأن الثيك أصدر في ألمانيا على بنك في فرنسا وأن جريمة الثيك بدون رصيد لا وجود لها في القانون الألمـاني وذلك لأن

(1) ديكـوك: بنيـان التكييـف القـانوني، ص 19 (1) ؛ لوفاسـير وديكـوك: المرجـع السابق فقـرة ؛ ؟،

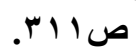

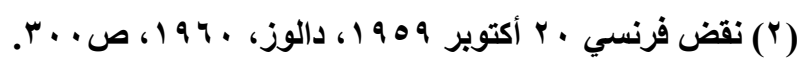
LAGARDE paul : la regle de conflit applicable aux question prealables. Rev. Crit dr. Inter. Pri. 1960.

(3) LOUSSOUARD (yyon) : Droit international du commerce et marche commun, Revue trimestrielle de droit commercial, 21e annee, 1959, No. 1 p. 557. 
المادة V من المعاهدة الدولية الخاصة بتنازع القوانين في مادة الشيك الموقعة في 19 مارس اسب9 19 والتي انضمت إليها كل من فرنسا وألمانيا تقضي بـأن القانون الواجب التطبيق هو قانون المكان الذي يجب فيه دفع مقابل الثيك، هذا من ناحية، ومن ناحية أخرى فإن قضاء النقض يعتبر جريمـة إصدار شيك بـون رصيد جريمـة مركبة يكفي فيهـا أن يكون الشيك قد سـب على بنـك في فرنسا لكي يختص القاضسي الفرنسي بالواقعة نظراً لأن العنصر الأساسـي في الجريمـة وهو تخلف الرصيد قد تحقق في فرنسا('). أما إذا كان الشيك واجب الدفع في الخـارج فإن اختصاص القانون التجـاري

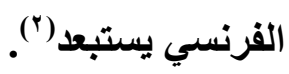

وتسسري ذات القاعـدة على المعارضــة في دفـع قيمسة الشيك وجـرائم الشيك الأخرى(") ففي دعوى تتلخص وقائعها في أن المتهم كان قد سحب شيكا على بنك في نيويورك. فقررت غرفة الاتهام بمحكمة استئناف بـاريس بعدم وجود وجـه نظراً لأن

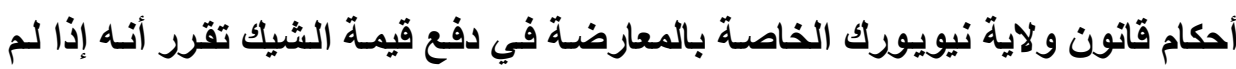

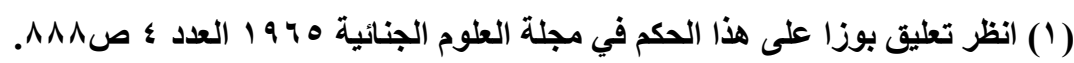

BOUZAT et BREDIN : Etude sur la competence internationale, Rapport au XIIIe conger inter, dr. Pen. Rev. Inter. Dr. Pen 1960. No. 2, p. 501.

(2) Trib. Corr. Thonon - les Bains: 27 mars 1958, J.C.P, 1958-2 10628;

Trib. Corr, Pourg-en Bresse; 7 juin 1961, J.C.P., 1962-2-12612; Trib.

Corr, aeine; 13 oct. 1965, Gaz. Pal. 1966-1-108.

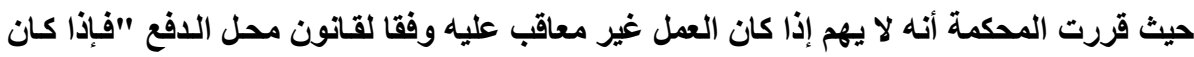

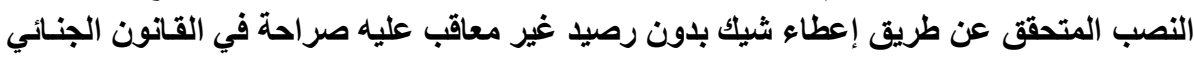

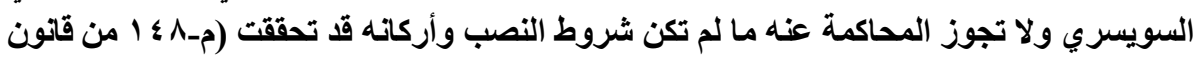

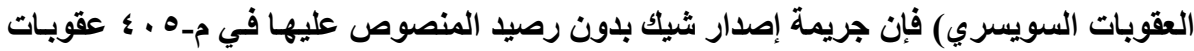
فرنسي تكون قد تحققت"

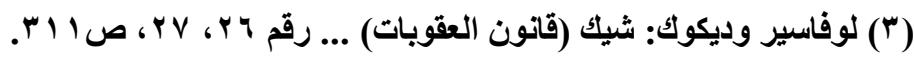


يتقدم المستفيد لقبض قيمة الثيك مدة سنة فإن رصيده يجمد لمصلحة الساحب إلى أن يصدر إذن خاص منه.وعدم إصدار هذا الإذن لا يعد معارضة في دفع قيمـة الشيك. فبإذا

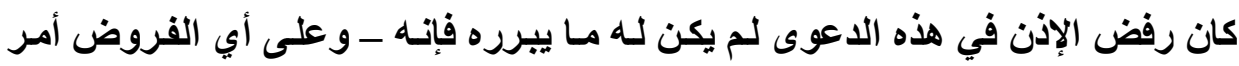
مشروع للذا قررت محكمـة استئناف بـاريس أنـه ليس مـن الـلازم أن تثتوافر الحالتـان

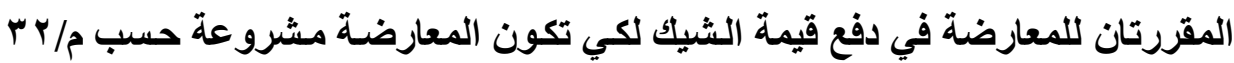

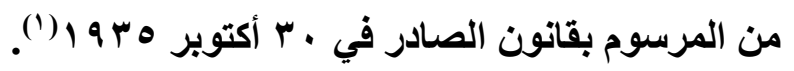

والخلاصة مما تقلم أنه حين يتعلق الأمر بتحديد مـا إذا كان الفعل المسند إلى

الساحب يوافق أو يعارض القانون من الوجهة المدنية. وهل يخضع بالتـالي للقانون الجنـائي يجب أن يكون الرجوع إلـى القـانون الذي تعينـه قاعدة التــازع في القـانون الدولي الخاص(") . وعلى العكس من ذلك حين يتعلق الأمر بأحكام جنائية فِإن قانون القاضـي يكون ذا تطبيق فوري بطريقة مطلقة مـع التحفظ بالنسبة لقاعدة التجريم المزدوج في حالة الاختصاص الشخصي حيث يأخذ القاضي الوطني في اعتباره القانون الجنائي الأجنبي في الدولة التي وقعت فيها الجريمة("). أما الوضع في قوانين الأحوال الثخصية فقد ذهب بعض الفقه إلى التفرقة بين نـوعين مـن القوانين الجنائيـة: النـوع الأول ــ أطلق عليه القوانين الجنائيـة الإقليميـة يلتزم القاضـي الوطني بتطبيقها على مـا يرتكب من جرائم فوق إقليم الاولـة، وهذه

(1) Cours d'appel de paris (ch. Accus.) 22 mars 1952, Gaz - pal. 1952-1423; BECQUE et CABRILlaC : Cheque, Rev. Trim. Dr. Comm. 1952. p. 405.

(2) LOUSSOUARN et BREDIN: Cheque, DALLOZ, Reprertoire de droit international, T.I, 1968, p. 306, 307.

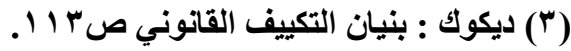


القوانين هي الأصل وتمثل غالبية القوانين الجنائية وتتولي هذه القوانين تحديد الوقائع المعاقب عليها وتكييفها القـانوني وطبيعة ومـدة العقوبـة وتنفيذها. أمـا النوع الثـاني القوانين الجنائية للأحوال الثخصية التي تمثل الاستثناء ومنه القوانين التي تعاقب على أنى تعدد الزوجـات والزنـا وتلكت التي تعاقب على الإخلال بالالتزامـات الناشئة عن رابطة الأبوة أو القرابة أو التبنـي. ومـع قبول التطبيق الإقليمي للقوانين الجنائية في مسائل

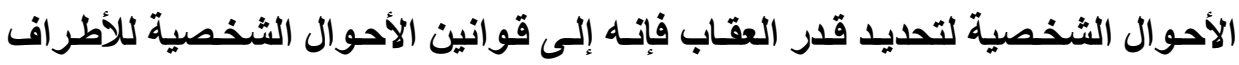
ينبفي الرجوع من أجل تحديد عناصر التجريم. كما يجب الرجوع أيضا لقانون الجنسية لتحديد سن المسئولية الجنائية وسن الحماية الجنائية. فالقاضسي الجنـائي يرجع لقانون

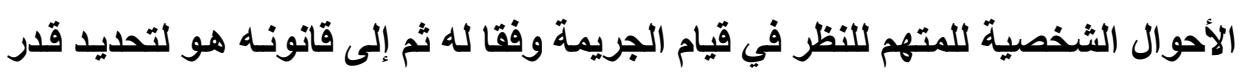
العقوبة. ولكن هذه النظرة لم تلق تأييدا في الفقه ولم يتبعها القضاء ('). فالثرط المفترض في جريمـة الزنـا هو قيـام الزوجية الصحيحة. ويلخل تقدير قيام هذا الشرط في مسائل الأحوال الشخصية بحيث يشكل مسألة فرعيـة أجازت المـادة r r r من قانون الإجراءات الجنائية المصري إيقاف الدعوى الجنائية في حالـة الدفع

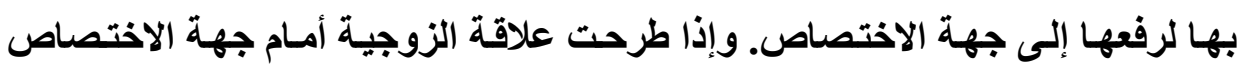
وكانت ذات عنصر أجنبي تولي القاضـي الفصل فيها وفقـا للقانون الذي تعينه قاعدة التنازع في القانون الدولي الخاص(؟). ويلاحظ أنه إذا أحالت قاعدة التنازع إلى قانون

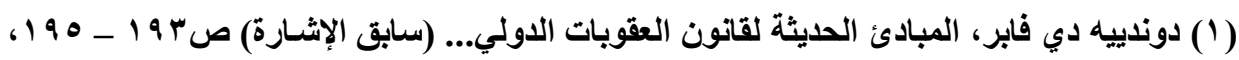

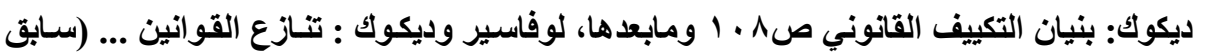

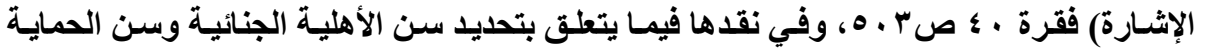

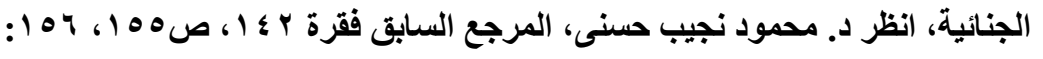

ROUX : Cours de droit criminal francais 2e ed paris. 1927, T.I. p. 66.

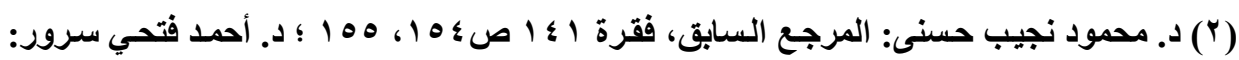

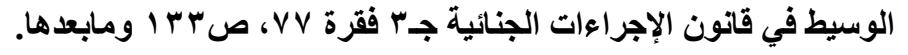


أجنبي في هذا الشأن فلن يكون تطبيقه بمعرفة القاضي الجنائي الوطني بل بمعرفة القاضي الوطني المختص بمسائل الأحوال الثخصية. ولكن النتائج التي يخلص إليها

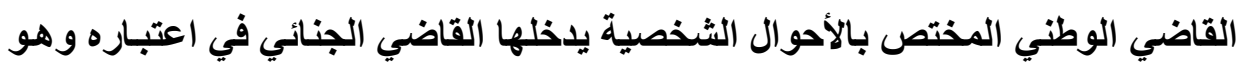
بصدد الفصل في الجريمة التي ضمت قيام الزوجية كثرط مفترض فيها.

وعلى أي الأحوال فإنـه يلزم التفرقة بثأن جريمة الزنـا بين الأحكام الجنائية والأحكام غير الجنائية المتعلقة بالثرط المفترض. فقيما يتعلق بالأحكام الجنائية، فإنها

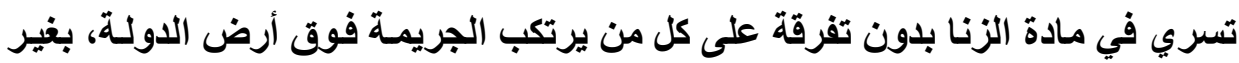

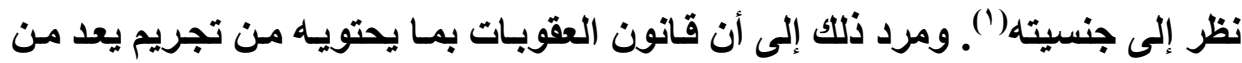

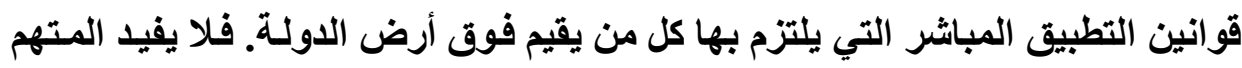

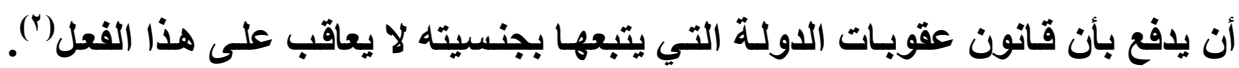

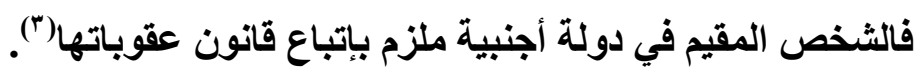
أمسا فيمـا يتعلق بالأحكام غير الجنائية المتعلقة بقيام الزوجية فإنها لا تخضع لقانون القاضي بالضرورة. فإذا كانت الزوجية محل إنكار أو كانت شرعية الزواج محل

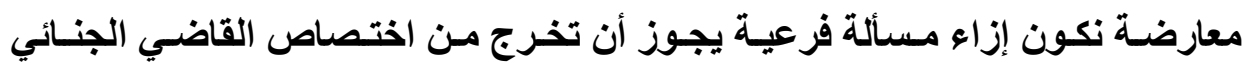

(1) LEVASSEUR et DECOCQ : Adultere, Repertiore de droit international T.I. 1968, No. II, p. 66; DUMAS; De L'adultee commis en France par des epoux etrangers rapport dans $L$ 'affaire Dame Trezza di MUSELLA, Clumet, 1901, p. 912.

(2) Crim 17 mai 1900, Clunet 1901, p. 102.

$$
\text { ولا يهم أن يكون الزواج خاضعاً لنظام مختلف عن الزواج في فرنسا. }
$$

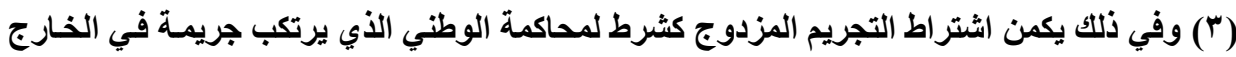
ثم يعود إلى وطنه (م-ب من قانون العقوبات الثصري). وأنظر في هذا الثنان:

Alger, 10 nov. 1894, Clunet 1895 p. 597. 
الوطني وتلذخل في اختصاص القاضي الوطني المختص بمسائل الأحوال الثخصية،

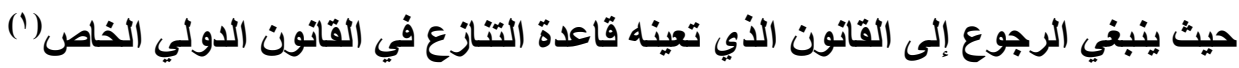

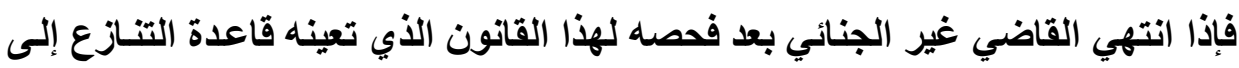

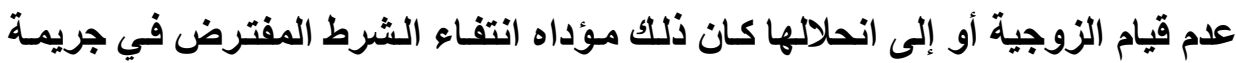
الزنا وتعين على القاضي الجنائي أن يقضي بالبراءة.

و إذا انتهي القاضي غير الجنائي إلى قيام الزوجية فليس من المحتم أن يقضي

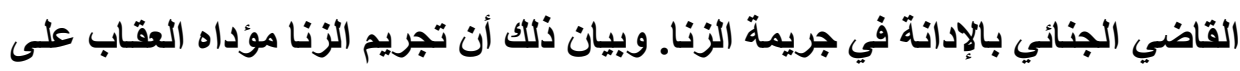

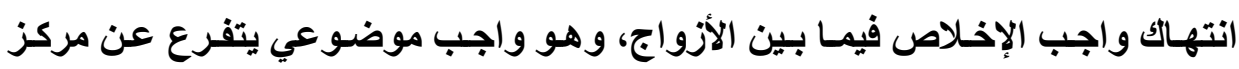

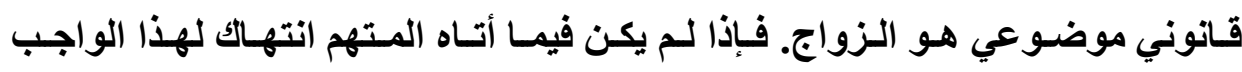
الموضوعي وفقا للقانون الواجب التطبيق على آثار الزواج كمـا تحدده قاعدة التنـازع التران في القانون الدولي الخاص فإن جريمة الزنا لا تقوم(؟).

ويتفق تحديد محكمة النقض لمفهوم مسائل الأحوال الثخصية مع فكرة الثروط المفترضة للجريمة حيث قضت بأن "حالات الأحوال الثخصية هي المتعقة بالصفات الطبيعية أو العائلية اللصيقة بثخص الإنسان والتي رتب القانون عليها أثراً في الحياة الأنال

(1) Trib. Corr. Seine : 9 dec 1879, Clunet, 1880, p. 189; 22 mars 1881 dlunet, 1882, p. 64; 13 fev. 1883, clunet 1883. p. 379.

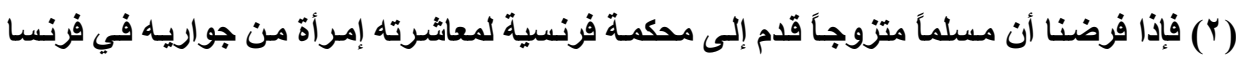

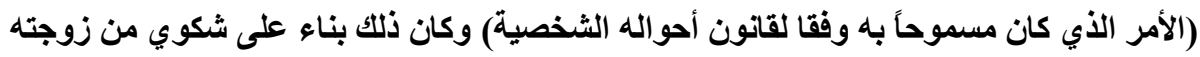

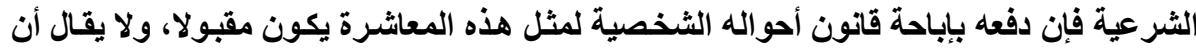

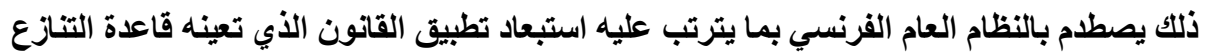

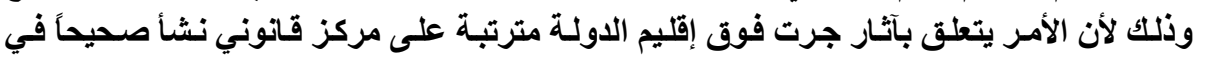

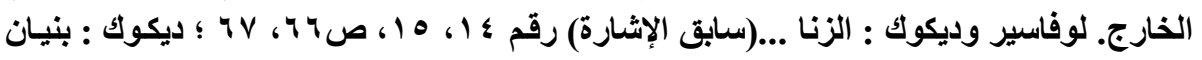

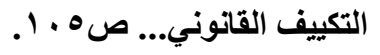




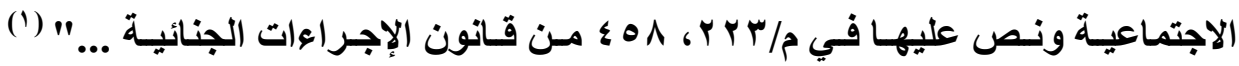
وقولهـا : "قصد الشارع بمـا أوجبه في م/بr r مس قـانون الإجراعات الجنائية (قبل

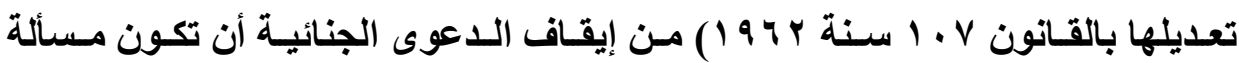
الأحوال الثخصية مما يتصل بركن من أركان الجريمة المرفوعة بها الدعوى الجنائية أو بشرط لا يتحقى وجود الجريمة إلا بوجوده..." ().

أمسا في جريمـة تعدد الزوجـات المنصوص عليهـا في المـادة . ـ ب مـن قـانون العقوبات الفرنسي التي تفترض قيام الزوجية الصحيحة. ويقع الركن المسادي فيها بعقد زواج ثـان صحيح (بغض النظر عن عيب التعدد) ("). ويحمي القـانون الجنـائي بهذا التجريم مبدأ مقرراً في القانون المدني الفرنسي هو مبدأ "وحدانية العلاقة الزوجية". ويلزم في هذه الجريمـة بـدورها أن نفرق بين الأحكام الجنائية المتعلقة بمبدأ التجريم وبنوع العقاب وقدره وبين الأحكام غير الجنائية المتعلقة بالشرط المفترض في هذه الجريمة وهو قيام الزوجية.

فقيما يتعلق بالأحكام الجنائية. يرجع القاضي الجنائي بشأنها إلى قانون عقوياته هو ولا يجدي المتهم الأجنبي نفعاً أن يدفع بـأن قانون أحوالهه الثخصية لا يعاقب على

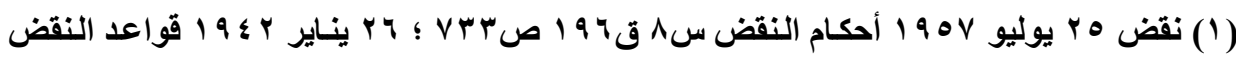
(ro)

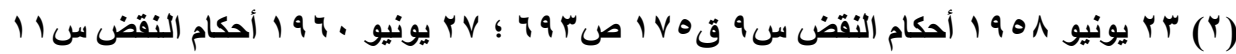

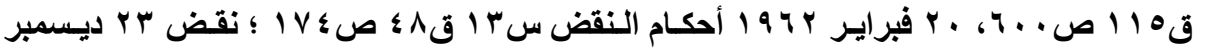

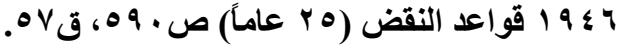

(3) LEVASSEUR et DECOCQ : Bigamie-Repertoire de droit international, Dalloz T.I, 1968, No. 4, p. 233. 
هذا الفعل جنائياً، كما أنه يعاقب بالعقوبات المقررة في القانون الفرنسي ('). وفي مقابل ذلك فإن الفرنسي الذي يعقد زواجاً ثانياً في الخارج لا يمكن أن يعاقب في فرنسا إلا إذا كان القانون الأجنبي يعاقب على هذا الفعل بحسبانه كذلك(؟).

أما فيما يتعلق بالأحكام غير الجنائية التي يرجع إليها للتثبت من قيام الشرط المفترض، فإنها تخضع للقانون الذي تعينه قاعدة التنازع في القانون الدولي الخـاص. فإذا ادعي المـتهم ببطلان الـزواج السابق أو انحلالهه، وبالتـالي إنكسار وجود الشرط المفترض في الجريمة اعتبر النظر في هذا الدفع مسألة فرعية(") تدخل في اختصاص القضاء المدني الفرنسي الذي يطبق القانون الذي تحدده قاعدة التـازع في القانون

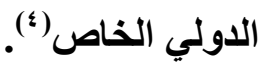
ويعد الدفع ببطلان الزواج في فرنسا، في حالة المحاكمة عن جريمة الزنا(ْ)، أو عن جريمة تعدد الزوجات(") دفعاً بمسألة فرعية لا يختص بها القاضي الجنائي، وكذلك الحال أيضا بالنسبة لمسألة البنوة حين تكون شرطا مفترضا في الجريمة أي حين تكون مركزاً قانونياً يسعي المشرع إلى حمايته بصفة أساسية (م/1 إــ من القانون المدني

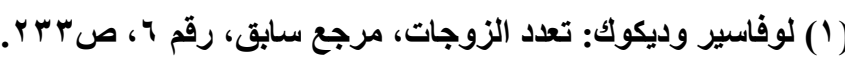

$$
\begin{aligned}
& \text { (ץ) انظر ديكوك : صم • 1). }
\end{aligned}
$$

(3) Cham, mise en accus Rennes : 23 janv 1879, clunet, 1882 p. 205.

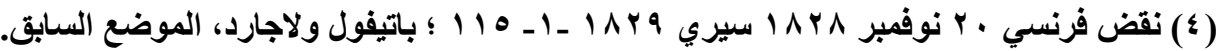

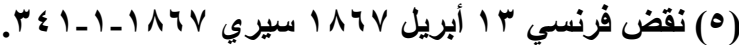

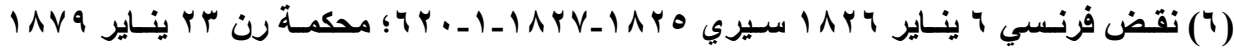

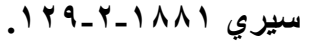


الفرنسي) (') بعكس الحالة التي لا تقابل فيها مسألة البنوة شرطا مفترضا في الجريمـة كما هو الثأن في جريمة قتل الآباء حيث تفصل فيها محكمة الجنايات دون أن يكون

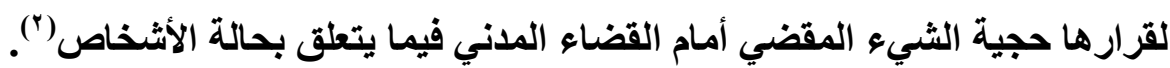
فيمكن للقاضي الوطن أن يرجع إلى قانون أجنبي لكي يحدد مـا إذا كـان المسلك قانوني أو غير قانوني في ذاته، ولكن إلى القانون الوطني ينبغي أن يكون الرجوع الـاني

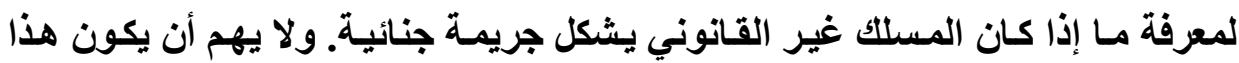
المسلك غير معاقب عليه جنائياً وفقاً للقانون الأجنبي ("). وحين يتطق الأمر بجرائم جنائية فإن الححاكم الوطنية ينبغي أن تطبق القانون الوطني وحده، ذلك أن استقلال قانون العقوبات ومـا يترتب عليه من تغيير في الأفكار و المفاهيم غير الجنائية يقود إلى إضفاء الطبيعة الجنائية على هذه الأحكام وتصبح أحكامًا جنائية يسري عليها مبدأ الإقليمية ولا تكون محلا للتنازع بين القوانين (8). وفي الرد على ذلك قيل إن قانون العقوبـات حين يحمي مركزاً قانونياً تنظمهـ قواعد غير جنائية فإنه يكون مجرداً من المضمون القاعدي المتعلق بـالمركز القانوني

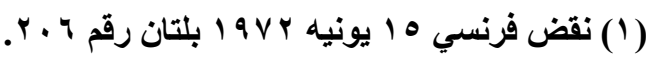

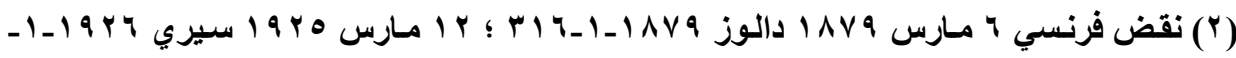
$.1 \wedge \mathrm{V}$

(ب) لوفاسير وديكوك: تنازع القوانين ... (سابق الإشارة) فقرة 10 صهـــــ ؛ ديكوك : بنيان التكييف

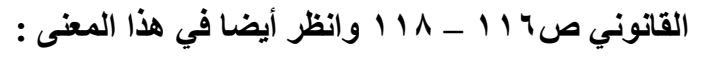

BATIFFOL : Traite elementaire de droit international prive, 4e ed paris L.E. D.J. 1968 P. 250.

(צ) انظر بوزا في تعليقه بمجلة العلوم الجنائية 1947 ص اOهr، به ب. 
الذي يتولى حمايته ويقترب بذلك من أن يكون قانونـاً جزائياً. كما قيل أيضا أنه من المنطقي أن تتغير طبيعة الأحكام غير الجنائية لمجرد أن جزاءات جنائية قد انضمت إلى بلى الجزاءات المدنية. ويكون المنطقي أن تستمر قاعدة التنازع في العمل حتى حين يتعلق

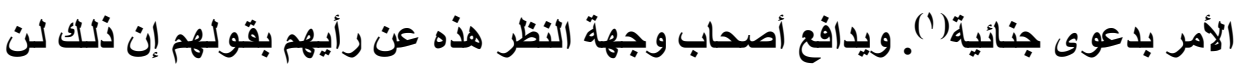
يكون فيه إهدار لاستقلال قانون العقوبات، فالأخير لا يمس بالضرورة كل أحكام القانون

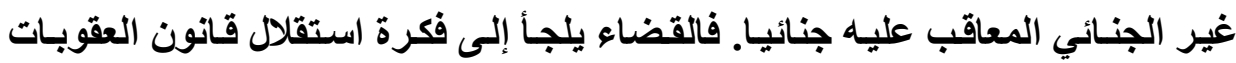
ليحبط الاحتماء في بعض القواعد غير الجنائية أو ليتصدى لحالة تشكل خطورة مـا في سلوك الأفراد. ولكن هذا لا يعنى أن استقلال قانون العقوبات يمكن أن يقود إلى معاقبة من يستخدم حقا مقرراً في قانون غير جنائي طالما لا يقف وراء ذلك إرادة إجرامية"(ب). وبيـان ذلك أن قانون العقوبـات يسعي في بعض الحسالات إلى أن يلحق ببعض صورد السلوك المجرم لاتتهاكه قو اعد غير جنائية، صوراً أخرى قريبة وخطيرة وتكشف عن بعن ذات القصد الجنائي. فهذه مجرد توسعه في القواعد غير الجنائية وليس أمسام تغيير في طبيعتها، ولن يكون هناك ما يحول والحال هكذا دون بقاء هذه الأحكام خاضعة لنظام

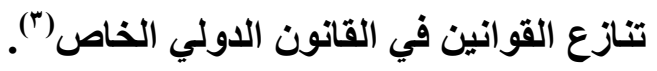

و الثانية أن يحدد القانون سنا معينـا يكتمل المتهم بيلوغها أهليته الجنائية، أو

يحدد سنا عينة تنتهي ببلوغها جدارة المجني عليه بنوع معين من الحماية الجنائية

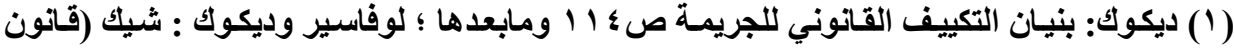

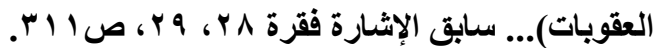

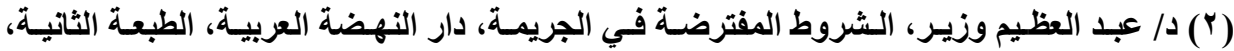

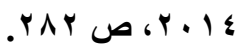

(3) DECOCQ : note sous trib. Corr. Seine, 13oct. 1965, Clunet 1966-p. 452. 
كالوضع في جرائم الاعتداء على العرض، ويرون وجوب الرجوع إلى القانون الجنـائي الأجنبي، وهو القـانون النافذ في الدولة التي يحمل المتهم أو المجني عليه جنسيتها لتحديد سنه. ويعللون ذلك بـأن القواعد الجنائية الخاصـة بالسن تقرر حمايـة شخصية للمتهم أو المجني عليه، مما ينبني عليه الرجوع إلى القانون الثخصي('). فضلا عن أن تطبيق القانون الأجنبي هو نوع من التعاون بين الدول لمكافحة الإجرام، إذ يتيح السبيل لإخضاع الجريمة لقانونها الطبيعي، وهو أقدر القوانين على دفع الخطر الناشئ عنها. ونلاحظ على هاتين الحالتين أن الأولي لا تثير جدالا، ذلك أنه إذا كان توافر أحد أركان الجريمة مقتضيا تطبيق قواعد غير جنائية، فبإن تحديد هذه القواعد وتفسيرها إنما يكون وفقا لذلك الفرع القانوني الذي تنتمي إليه،، فإن قضت أحكامسه الرجوع إلى قانون أجنبي تعين أعمـال مـا تقضي بـه، فهذه الحالـة في حقيقتها لا تحكمها قواعد القانون الجنائي، وإنما تحكمها قواعد غير جنائية لها طبيعتها وأحكامها. أمـا الحالة الثانيـة، فـالر أي الذي يقول بـه أنصار تطبيق القانون الأجنبي غير صحيح، فتحديد سن يتعين أن يبلغها المتهم كي تكتمل أهليته الجنائية هو بيـان للقواعد التي تحكم أحـد أركـان الجريمـة، إذ لا يتوافر الركن المعنوي مـا لـم يكن المتهم أهـلا، وتحديد سن المجني عليه لتقدير جدارته بحماية جنائية معينة هو كذلك بيان لأحد أركان الجريمة، فليس المقصود تقرير حماية شخصية، وإنما رسم نطاق الحماية التي يسديها القـانون الجنـائي للمجتمـع وبيـان حدودها، ومـن ثـم لا يكون ثمـة مبرر للرجـوع إلى

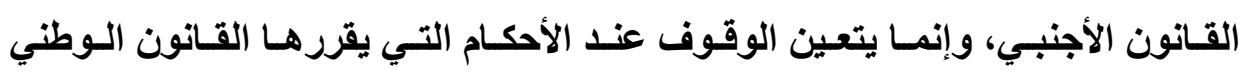

(1) Donnedieu de Vabres, no. 1678, p. 945. 
باعتبارها التي تعبر عن وجهة نظر المجتمع في نوع ومقدار الحمايـة الجنائية التي تلزمه (')

وتحقيتق التعـاون بـين الـدول في مكافحـة الإجـرام لا يتطلب تطبيق القـوانين الأجنبية، إذ يمكن تحقيقه عن طريق نظام "تسليم المجرمين" في الحالات التي تقدر فيها الدولة أن من المصلحة تسليم المتهم إلى دولـة أخرى كي تحاكمـه طبقا لقانونها. وفي هذا يمكن تقرير حق المتهم في تطبيق قانونه إذا كان أخف من قانون القاضسي أو

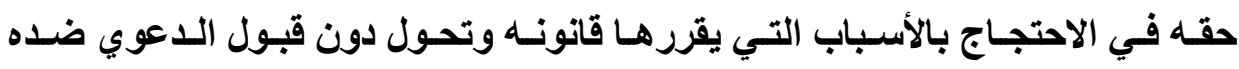
كالتقادم أو عدم تقديم شكوى.

ومن جماع ما سبق يمكن القول أن الأسـاس القـانوني لتطبيق القاضسي الوطني للقانون الجنائي الأجنبي يتمثل في إبرام الاتفاقيات الدولية. فتطبيق القاضسي الوطني للقانون الجنائي الأجنبي، أصبح أمراً ميسوراً خاصة بعد أن أخذ القاضسي الوطني في اعتباره الأحكام الجنائية الأجنبية واعترف بالقوة التففيذية لها، وإن كاتت هنـاك بعض التحفظات أو الشروط التي يخضع لها، والتي تضمن حسن إدارة العدالة، والتطبيق الجيد للنصوص بمـا لا يتعسارض مـع المبادئ الأساسية في التشريع الوطني. كمـا أن تحويل الإجراعات أو المحاكمات من دولـة معينة إلى دولـة أخرى، يعد في واقع الأمر تفويضاً من السلطات المختصة بالمحاكمـة أصلاً لسلطات أخرى قد لا تكون مختصة، وقيام الثانية بمباشرة مهامها القضائية قبل المذنب، يجعل من بـاب أولي تطبيق قانون

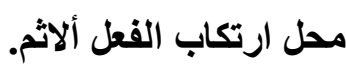


فالقاضسي الجنـائي عند تطبيق القـانون الجنـائي الأجنبـي يتعرض لموضـوعات

التحقيقات وتسليم المجرمين والآثار الاولية للأحكام الجنائية الأجنبية.

أ) التصقيـقات :

تهتم الاتفاقيات الدولية بضرورة إجراء التحقيقات بين الدول عن طريق الإنابة القضائية الدولية المقررة في التشريعات الداخلية، ويمكن الالتجاء في ذلك إلى الطرق الدبلوماسية لسرعة تحول التحقيقات وإنجاز هـا بين الدولـة الطالبة، والمطلوب منهـا التنفيذ، والاتصال المباثر بين وزارتي العدل في هـاتين الدولتين يساعد على سرعة إتمام التحقيقات وإصدار الأحكام المناسبة)(')

\section{ب) تسليم المجرهين :}

ترفض العديد من الاول تسليم المجرمين الوطنيين، خاصة إذا ما تبين لها عدم

خطورة الجريمة المرتكبة، ولاسيما لو كـان تشريع تلك الدولة لا ينص على اعتبارهـا كـلك. وهـا المبدأ يحـول دون تطبيـق القاضـي الجنـائي لقـانون محل ارتكـاب الفعل الإجرامي، بل قد يترتب عليه إفلات العديد من الجناة من المحاكمـة، خاصـة إذا لـم يثبت الاختصاص للقضاء الوطني بالنسبة للواقعة المرتكبة بالخارج. ومـع ذلك فـإن بعض الدول لا تضضع أي تحفظ بالنسبة لقاعدة "عدم تسليم الـوطنيين". كمـا أوصسي المـؤتمر الـدولي لتوحيــ قـانون العقوبـات الـذي انعقد في

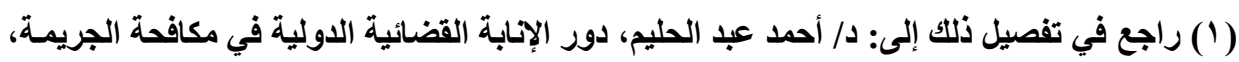

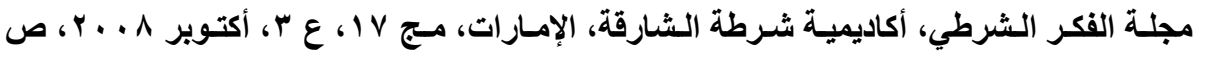


كوبنهاجن عام هـ 9 (، بإجازة "تسليم الرعايا الوطنيين"، كما أكد على ضرورة تعقب

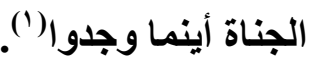

\section{ج) الآثار الدولية للأحكام البنائية :}

تعرف العديد من تشريعات الدول بـالأثر السلبي للحكم الجنـائي الأجنبي، حيث

يحول ذلك دون إعـادة المحاكمة عن نفس الواقعة من جليد، متى أصبح هذا الحكم نهائياً، بينما تأخذ قلة من التشريعات بالآثار الإيجابية للأحكام الجنائية الأجنبية، فتجيز تنفيذ تلك الأحكام في نطاق محدود، وتضع بعض التحفظات الخاصة بالنسبة للعود، وعدم الأهلية، وسقوط الحق(`).

(1) د/ يسر أنور علي ، شرح النظريات العامة للقانون الجنائي، الجزء الأول، ه1911، ص 011. (2) LOMBOIS, CL : Droit penal international, D. $2^{\mathrm{e}}$ ed, Dalloz, Paris, 1979.P.243. 


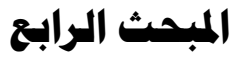 \\ دور القاضي الجنائي في تهديد هضمون القانون الأجنبي}

إذا كان القانون الجنائي الأجنبي هو "مجموعة القواعد القانونية الصادرة من

السلطة التشريعية في الاول الأجنبية، والتي يكون من شـأنها الحفـاظ على النظام العام في هذه الاول". إلا أنه في مجـال التطبيق يقصد بـه الإذعان لتطبيق القانون الجنـائي الأجنبي للوصول إلي تكييف الجريمة، أو عقوبتها، أو النتائج القانونية للواقعة المعاقب عليها، أو لنص من نصوص الأحكام العامة من القسم العام للقانون الجنائي (').

فالقاضي إما أن يطبق القانون الأجنبي كما لو كان قانونه الوطني، أو يرجع إليه ليضع في اعتباره أوجـه الاختلاف بين القانونين مـع تغليب أيهمـا أصلح للمتهم بغية تحقيق حسن سير العدالة وضمان فاعلية المساواة بين الجناة(؟). وخلاصة ما سبق يمكن القول ضرورة تحديد الخطأ طبقا لظروف مكان الجريمـة عبر اعتراف كل دولـة بضرورة تطبيق قـانون محل ارتكـاب الفعل الإجرامسي إثباتـا

(1) FURTADO DOS SANTOS, A. : L'application de la loi penale etrangere par le juge national, Rapp. Presente au VIIIe C.I.D.P., in R.I.D.P, 1960, No. 3 et 4, p. 568 et. ss.

راجع في تحديد مدلول تطبيق القانون الجنائي الأجنبي التقارير لمقدمة إلى المؤتمر الثامن لقانون

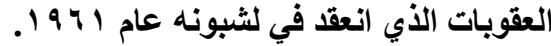

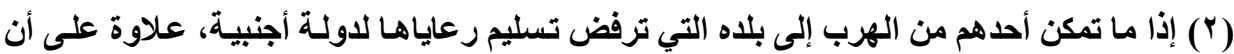

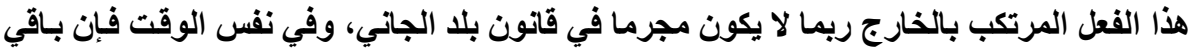
الثركاء قد ينالون أثند الجزاء عن تلك الجريمة. 
وتفسيرا بصرف النظر عن جنسية مرتكبها، أو جنسية المجني عليه، أو مدي تقدير العقوبة من حيث التخفيف أو التشديد، وذلك لتجنب الأضرار التي تصيب مصلحة الدول

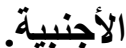

ويشمل تطبيق القانون الجنائي الأجنبي كل جرائم القـانون العام فيمـا عدا مـا

يتعارض مع النظام العام في بلا القاضي، أو مـا يتعلق بـالجرائم السياسية أو العسكرية أو المالية لوجود اختلاف كبير بين التشريعات الوطنية في تحديد مفهوم هذه الجرائم والنظرة إليها. كما يقتصر ذلك التطبيق على الجرائم المرتكبة داخل البلاد مـع مراعاة الروابط العائلية بين الجاني والمجني عليه أو الغير والتي قد تتبع قواعد القانون الدولي

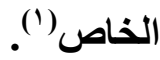

كما يمكن تطبيق القانون الجنائي الأجنبي بصفة أساسية، وليس بصفة احتياطية في حالة استحالة التسليم. فالدولة التي وقعت على أرضهـا الجريمـة، يجب أن تطالب الدولة التي تأوي الجاني إما بتسليمه إليها، أو تقديمه للمحاكمة أمام محاكمها، على أن تطبق قانون محل ارتكاب الفعل الإجرامي. فالقانون الجنائي الأجنبي قابل للتطبيق على الوقائع القابلة للعقاب والمرتكبة بالخارج دون النظر لجنسية الجاني(؟).

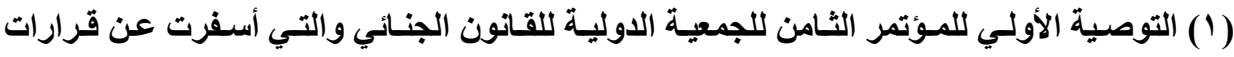

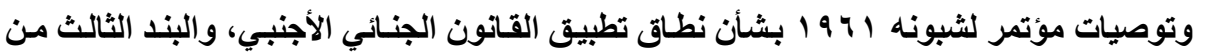

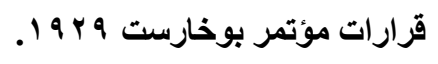

(2) VAN BEMMELEN, J.M. : L'application de la loi etrangere par le juge national, Rapp. General definitif au VIIIe C.I.D.P. in R.I.D.P. 1960, PP. 641 et. ss. 
وكذلك الحال في حالة صدور حكم جنائي أجنبي غيابي ويراد تنفيذه في بلد مسا، فبان الجاني له حق المعارضة في تنفيذ هذا الحكم أمسام محاكم الدولـة التي أصدرت الحكم. وإمـا أن يعارض في هذا الحكم أمام محاكم الدولة التي تأويه، على أن يطبق قانون محل ارتكاب الفعل الإجرامي.

فيشترط لتطبيق القانون الجنائي الأجنبي شرط ازدواج التجريم المنصوص عليه

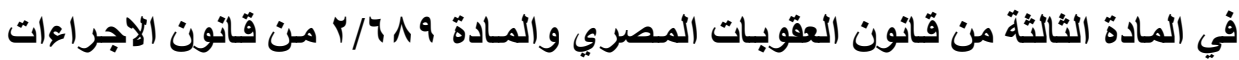
الجنائيـة الفرنسي ويقصد بـه أن يكون الفعل المرتكب بالخـارج يشكل جريمـة طبقاً لقانون تلك الدولة، بصرف النظر عن الوصف القانوني لله أو خطورتهـهـ وفي معرض ذلك يمكن القول أن القاضـي الوطني عندما يحكم طبقاً لقانونـه الخـاص على الجريمـة التي وقعت في الخـارج، عليه أن يراعي ألا تتجـاوز العقوبـة الحد الأقصى المنصوص عليها في قانون البلا الذي ارتكبث في ظله الجريمة(')

وسند ذلك أن هذا المجرم كان يجب عليه أن يخضع لقانون محل ارتكـاب الفعل ويحاكم طبقا له، تطبيقاً لمبدأ "لا جريمة ولا عقوبة إلا بناء على قانون"، وبالتالي فلا

(1) Article 689 En application des conventions internationales visées aux articles suivants, peut être poursuivie et jugée par les juridictions françaises, si elle se trouve en France, toute personne qui s'est rendue coupable hors du territoire de la République de l'une des infractions énumérées par ces articles. Les dispositions du présent article sont applicables à la tentative de ces infractions, chaque fois que celle-ci est punissable. Modifié par Loi nº9-515 du 23 juin 1999 - art. 30 JORF 24 juin 1999. 
يجوز أن يفرض على المتهم نص قانوني لم يتوقعه، وكذا لا يجوز أن يضار المتهم من جراء تطبيق قانونه الخاص، خاصة وأن المتهم يشعر بالحماية الخاصة من دولته.

$$
\text { تطبيق القانون الأصلح للمتهم : }
$$

كمـا ذهبـت بعض التشريعات ومنهـا قـانون العقوبـات السويسري في المـادة

السـادسة منــه إلـي ضـرورة الأخــذ في الاعتبـار جميـع الظـروف الخاصـة بالواقعـة الإجرامية، وبحث حالات تثديد العقوبة في كلا القانونين "قانون القاضي وقانون محل ارتكـاب الجريمـة"، وكذا بحث القواعد الخاصـة بالعقوبة والظروف المخففة لها، مـع . عمل نوع مـن المقارنـة أو الموازنـة بين القانونين، وتطبيق القـانون الأصلّح للمتهم، وفي حالة المساواة بينهما، فإن القانون الوطني سيطبق على الواقعة الإجرامية التي ارتكبت بالخارج.

ولم يأخذ المشرع المصري بهذا الاتجاه فاقتصر فقط علي شرط ازدواج التجريم كمتطلب لتطبيق القانون الجنائي الأجنبي. وعلي العكس من ذلك يطبق القاضي الوطني قانونـه الخـاص على الواقعة الإجراميـة التـي ارتكبت في الخـارج، حتى لـو أدي ذلتك التطبيق إلى توقيع عقوبة أشد مما هو منصوص عليها في تثريع الدولة الأجنبية، التي

$$
\text { ارتكبت على إقليمها الجريمة('). }
$$

(1) GRUETZNER, H. : L'application de la loi penale etrangere par le juge national, Rapp. Allemand. Pressente au VIIIe C.I.D.P., in R.I.D.P. 1960, PP. 397 et. ss.

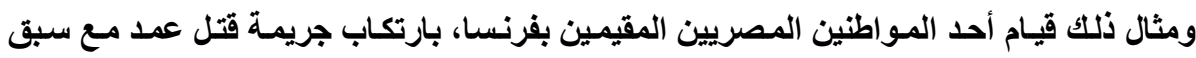

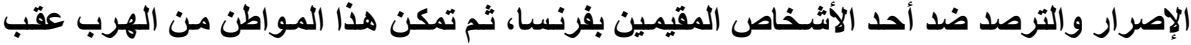

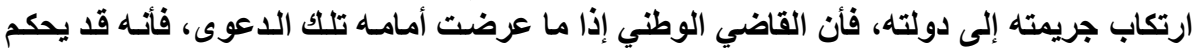

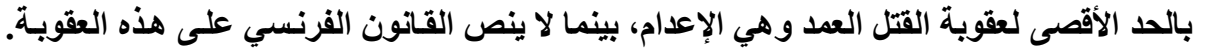
$=$ 


\section{سلطة القاضي الجنائي في البحث عن هضمون القانون الأجنبي}

يختلف تحديد سلطة القاضي الجنائي الوطني في البحث عن مضمون القانون

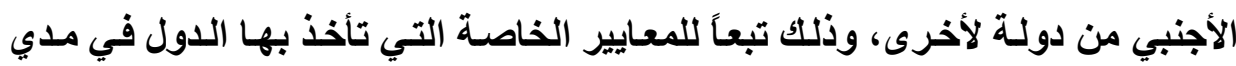

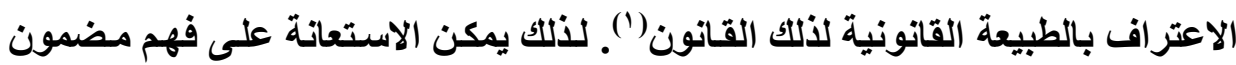
القـانون الأجنبـي بإنشاء هيئة أو مركز أو معهد متخصص مهمتــهـ تجميع القـوانين


وفهارس لها، لسهولة الإطلاع عليها، مـع تجميع أكبر قد ممكن من الأحكام الأجنبية

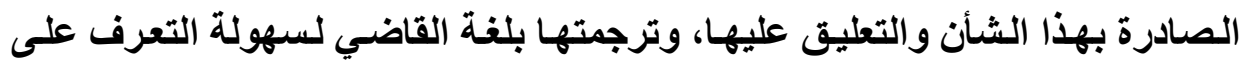
مضمونها. أو تشجيع الباحثين على القيام بعدل دراسـات مقارنـة في مختلف الفروع القانونيـة، لتمــ الهيئة أو المعهد المتخصص في هذه العلوم، بـأكبر قدر ممكن مـن المعلومات عن القوانين الأجنبية المقارنة.

كما يجب العمل على عقد المعاهدات والاتفاقيات الدولية الثنائية منها، والمتعددة الأطر اف، والتي بمقتضاها يتم تبـادل المعلومـات القانونيـة اللازمـة تبعاً لمبدأ المعاملة بالمثل، مع عدم تلدخل الاعتبـارات السياسية في التأثير على المعلومـات المطلوبـة. أو

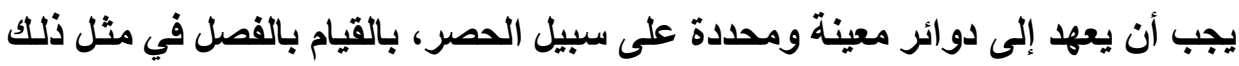
النوع من المنازعات، حيث قد يحقق ذلك نوعاً من التخصص يكسب القـائمين عليه مرانا كبيراً وخبرة واسعة مع تعدد عرض هذه النوعية عليهم.

وبالتالي فلو مثل هذا المتهم أمام المحاكم الفرنسية، فقي جميع الأحوال، لن يحكم عليه بالعقوبة الثديدة التي حكم عليه بها في دولتها

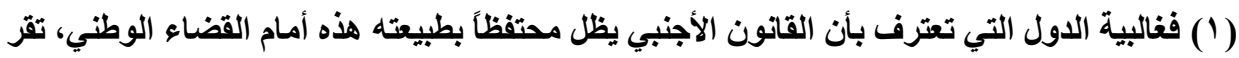

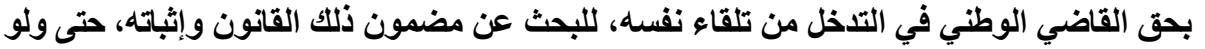

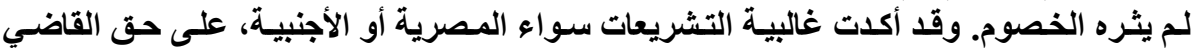
الوطني في تطبيق القانون الأجنبي - الذي أثشارت قاعدة الإسناد باختصاصه ــ من تلقاء نفسه. 


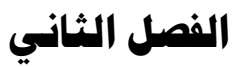

تطبيق القاضي الجنائي للقانون الجنائي الأجنبي

سوف نعرض في هذا الفصل لتطبيق القاضي الجنائي للقانون الجنائي الأجنبي،

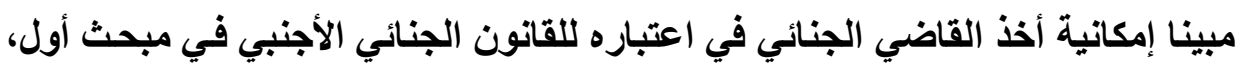
ثم نبين الأخذ في الاعتبار الأحكام الجنائية الأجنبية في مبحث ثان، ثم نقف علي طبيعة المحررات الرسمية الأجنبيـة، وأخيرا نتصدي للأحكام الجنائية الأجنبية في القانون

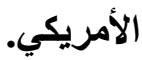

\section{المبحث الأول}

الأخذ في الاعتبار القانون الجنائي الأجنبي

نتعرض في هذا المبحث لموقف الققه مـن رجوع القاضسي الجنائي للقـانون

الجنائي الأجنبي في مطلب أول، ثم نبين شروط تطبيق القانون الجنائي الأجنبي في مطلب ثاني. 


\section{المطلب الأول}

رجوع القاضي الجنائي للقانون الجنائي الأجنبي

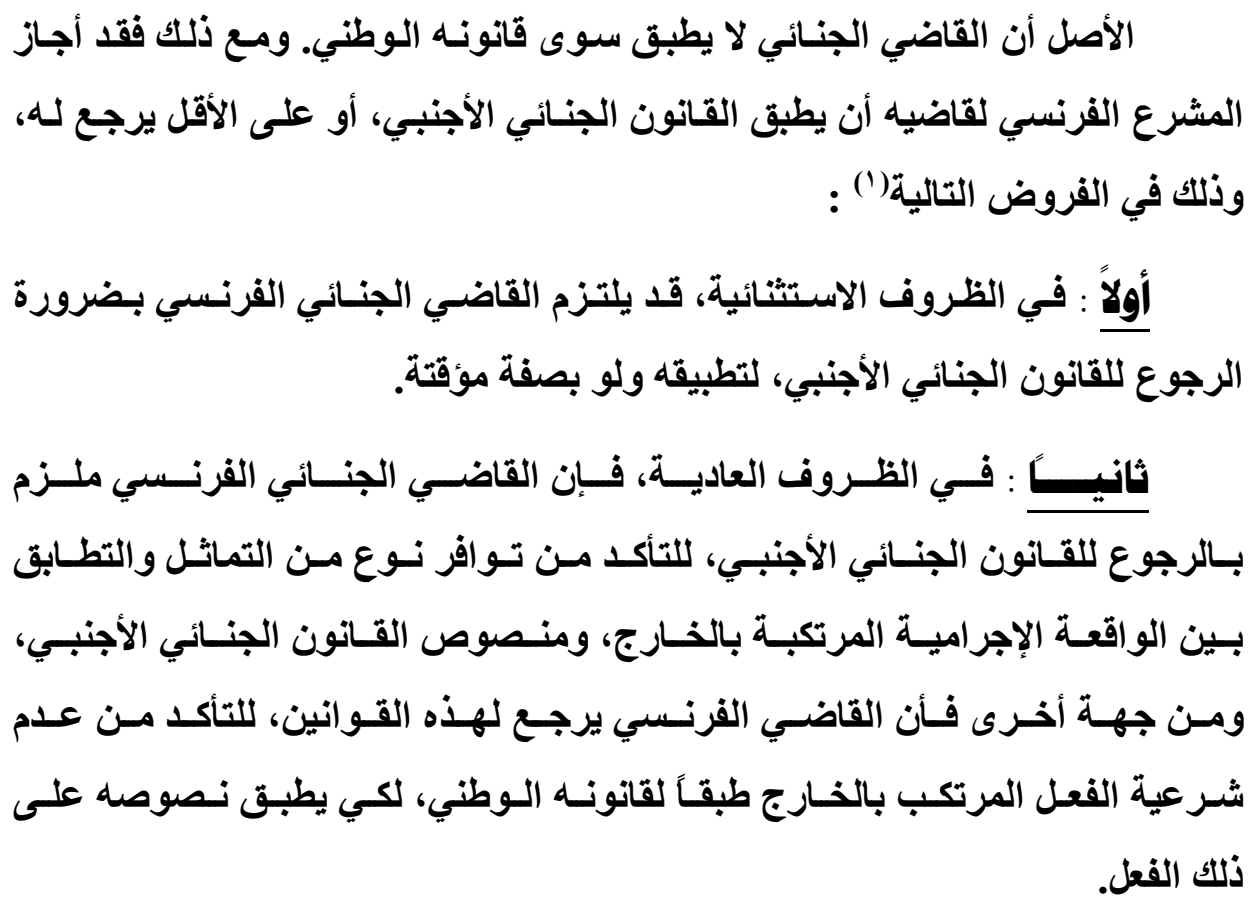

(1) LE CALVEZ, J. : Compétence législative et compétence judiciaire en droit pénal, la remise en cause du principe selon lequel le juge répressif n'applique que sa loi national, In R.S.C., 1980, PP. 13 et. ss., 337 et. ss. BOUZAT, P. : L'application de la loi penal etranger par le juge national, in cours de l'institu des hautes etudes internationales des l'universite de paris, 1966 - 1967, pp. ${ }^{r}$ et. ss. 


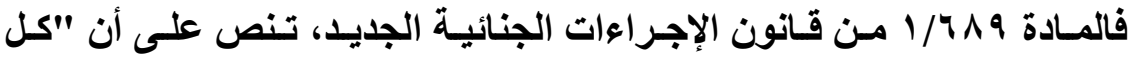

مواطن فرنسي خارج إقليم الجمهوريـة، إذا كـان متهمـاً في واقعة جنائية طبقاً للقانون الفرنسي، فأنه يحاكم أمام القضاء الفرنسي، إذا كانت تللك الواقعة معاقباً عليها بواسطة تشريع البلد الذي ارتكب فيـه الجريمـة. لذلك يلزم رجوع القاضسي الجنـائي الفرنسي للقانون الجنائي الأجنبي، ليكون عالماً وملماً بمضمون وأحكام هذا القانون، للتأكد من أن الواقعة مجرمة في مكان ارتكابها بالخارج، وللتأكد من سلامة التكييف القانوني لها.

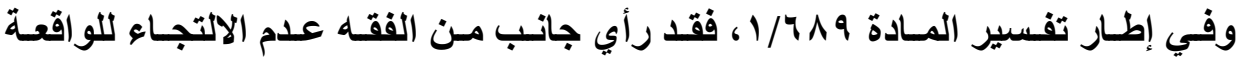
الإجرامية التي تمت بالخارج، إذا كان الجاني قد حصل على حكم نهائي فيها، أو سقطت بالتقادم، أو صدر عفو عنها(') ومع ذلك قبلت محكمة النقض الفرنسية ضمنياً الأحكـام الصادرة بالخـارج عن وقائع جنائية، حتى ولو سقطت بالتقادم أو صدر عنها عفو عام، وإن كان هذا الاتجـاه

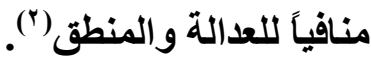

(1) Article 689-1 En application des conventions internationales visées aux articles suivants, peut être poursuivie et jugée par les juridictions françaises, si elle se trouve en France, toute personne qui s'est rendue coupable hors du territoire de la République de l'une des infractions énumérées par ces articles. Les dispositions du présent article sont applicables à la tentative de ces infractions, chaque fois que celle-ci est punissable. Modifié par Loi n99-515 du 23 juin 1999 - art. 30 JORF 24 juin 1999.

(2) LOMBOIS, C. : Commentaire de l'avant-projet, Definitif de revision du code penal, 1978, In R.I.D.P., 1980, PP. 55 et. ss. Crim.31 déc.1936,G.P.1937.1.420. 
ثالثًا : في حالة وقوع الفعل الإجرامي بالخارج بناء على فعل الاشتراك الذي تم

بفرنسا، فإن الشريك سيقدم للمحاكمة أمسام القضاء الفرنسي، بشرط أن تكون الواقعة معاقبا عليها مرة في القانون الأجنبي، ومرة أخرى في القانون الفرنسي، كمـا يشترط أن توصف هذه الواقعة بأنها جنايـة أو جنحة، ويصدر حكم نهائي بـات مـن القضاء

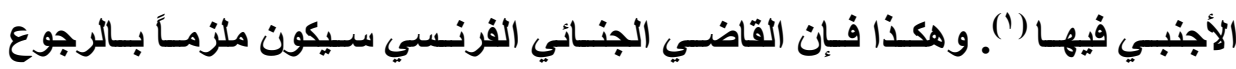

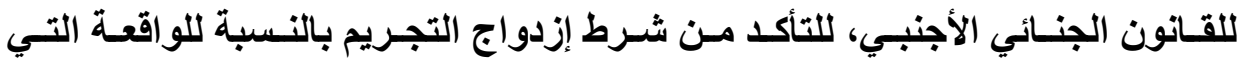
ارتكبت بالخـارج، والتحقق من صدور حكم نهائي بـات من القضاء الأجنبي في هذه

رابعًا : كذلك في حالة تسليم المجرمين، فبإن القاضسي الفرنسي ملزم بـالرجوع للقانون الجنائي الأجنبي للاولة الطالبة، لمعرفة الأسس التي يقوم عليها طلب التسليم ومبرراته، والقانون الذي يستند إليه، وعمـا إذا كـان يوافق نصوص القانون الفرنسي من عدمـه، والتأكد من مدي شرعية طلب التسليم، من حيث تقدير العقوبـة الواجبـة التطبيق على الجريمة محل التسليم وظروفها، لرفض هذا الطلب إذا مـا كانت الجريمـة سياسية أو عسكرية. وعلى ذلك فإن القاضي الفرنسي ملزم بـالرجوع للقانون الجنـائي

(1) Article 689: Les auteurs ou complices d'infractions commises hors du territoire de la République peuvent être poursuivis et jugés par les juridictions françaises soit lorsque, conformément aux dispositions du livre Ier du code pénal ou d'un autre texte législatif, la loi française est applicable, soit lorsqu'une convention internationale ou un acte pris en application du traité instituant les Communautés européennes donne compétence aux juridictions françaises pour connaître de l'infraction. 
الأجنبي، للتحقق من مدي مطابقته لنظامه العام، ومدي توافر الشروط المتطلبة للتسليم للموافقة عليه أو رفضه(')

و إذا كانت القاعدة العامة في فرنسا، أن الأحكام الجنائية لا يكون لها أي أثر إلا

على إقليم الدولة التي أصدرتها، ونتيجة لذلك فأن الأحكام الجنائية الأجنبية لا يعتد بها في فرنسا، ولا يترتب عليها أية آثار. إلا أن المادة ب 9 و من قانون الإجراءات الجنائية الفرنسي الجديد ـ احترام مبدأ عدم جواز محاكمة الثخص أكثر من مرة عن فعل واحد، وبذا فإن المشرع الفرنسي قد سمح لقاضيه الجنائي أن يضع في اعتباره الحكم الجنائي

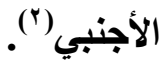

فباذا كانت نـصوص القـانون الفرنسي لا تطبق القـانون الجنـائي الأجنبي، فبان أخذها في الاعتبـار بالأحكام الجنائية الأجنبيـة، يعد تطبيقاً غير مباشر لهذا القانون، بمعنى أن القاضي الفرنسي يعترف ويقر بالقانون الجنائي الأجنبي. فعندما تعرض أمسام القضاء الفرنسي دعوى جنائية، ويتبين سبق فحصها أمام قضاء دولة أخرى، وصدور

(1) KOERING-JOULIN, R. : Conflit de lois et de competence, Infractions commises a l'etranger, Fasc 403, Art. 689 a 696, Jur. Cl. Proc. Pen, 5, 1977. \& Structutes et methodes de la cooperation repressive internationale et regionale, (a l'exclusion de l'extradition), Actes du colloque preparatoire au XIIIe congres international tenu strasbourg (France), 5-7 sep. 1983, R.I.D.P.,1984, No. 1 et 2, pp. 147 et. ss.

(2) Article 692 :Dans les cas prévus au chapitre précédent, aucune poursuite ne peut être exercée contre une personne justifiant qu'elle a été jugée définitivement à l'étranger pour les mêmes faits et, en cas de condamnation, que la peine a été subie ou prescrite. Modifié par Loi n'99-515 du 23 juin 1999 - art. 30 JORF 24 juin 1999 
حكم نهائي في هذا الثـأن، فأنـا يتأكد من صحة تطبيق القانون الجنـائي الأجنبي على الواقعة الإجراميـة، ويستبعد تطبيق القانون الوطني على الدعوى الجنائية في هذه الحالة، وحتى لو لـ يعترف بهذا الحكم بصفة عامـة، فسوف يكون محل اعتبـار أمسام القاضي الفرنسي، من حيث الوقائع التي ثبتت صحتها في الحكم، والتأكد من أن الجـاني نفذ عقوبته من عدمه، لخصمها من العقوبة الجديدة أو الاكتفاء بها' (1). وفضلاً عن ذلك، فبان القاضسي الجنـائي الفرنسي قد يكون مضطر اللرجوع للقانون الجنائي الأجنبي في حالة إدعاء الجاني سبق تنفيذ عقويته بالخارج أو سقوطها بالتقادم، أو حصوله على عفو عنها، طبقاً للمادة ب 99 من قانون الإجراءات الجنائية، وذلك للتأكد من توافر شروط تنفيذ العقوبة، والمدة المحددة لانقضائها، خاصـة في الحالات التي يقر فيها القانون الفرنسي بالوضع في الاعتبار القانون الأجنبي، مثل حالة عدم الأهلية، أو سقوط الحق الصادر بالخارج. و إذا كان القضاء الفرنسي قد استبعد الاعتراف بالأحكام الجنائية الأجنبية، إلا أنـه يتمسكك بهـا كأحــ المـصـادر الهامـة في معرفـة القـانون الجنـائي الأجنبـي، لتحديـ المسئولية الجنائية للمجرم أمام القاضي الوطني، والتعرف على عنصر تفريد العقوبـات القضائية، والظروف الخاصـة بالواقعة، ويظهر ذلك من نص المـادة 4 ل V من قانون الإجراءات الجنائية، التي تتعلق بمدي الأخذ بصحيفة السوابق الخاصـة بـالمتهم الذي

(1) BOUZAT, P. : L'application de la loi penal etranger par le juge national, in cours de l'institu des hautes etudes internationales des l'universite de paris, 1966 - 1967, pp. 25et. ss. 


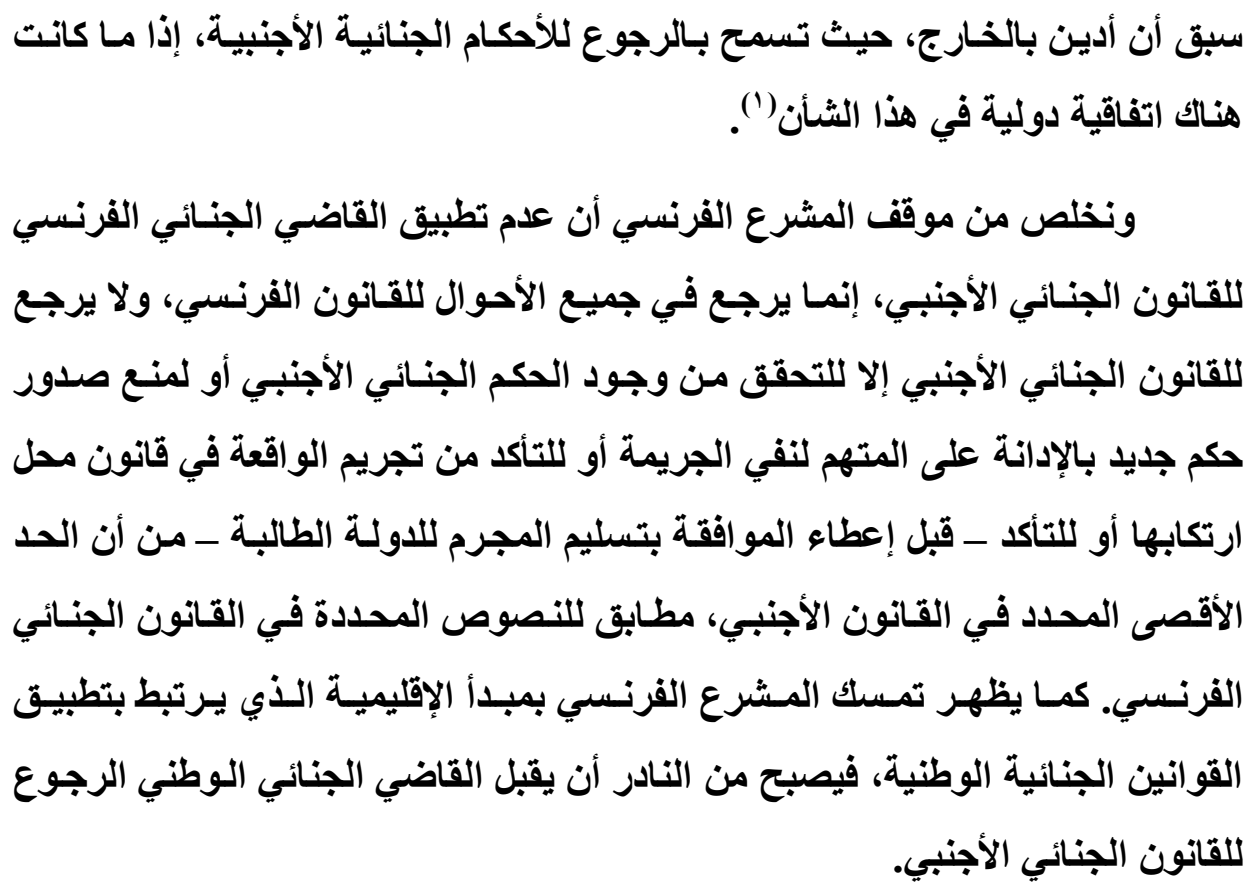

(1) Article 768: Modifié par LOI n²010-242 du 10 mars 2010 - art. 16 Le casier judiciaire national automatisé, qui peut comporter un ou plusieurs centres de traitement, est tenu sous l'autorité du ministre de la justice. Il reçoit, en ce qui concerne les personnes nées en France et après contrôle de leur identité au moyen du répertoire national d'identification des personnes physiques, le numéro d'identification ne pouvant en aucun cas servir de base à la vérification de l'identité $: 8^{\circ}$ Les condamnations prononcées par les juridictions étrangères qui, en application d'une convention ou d'un accord internationaux, ont fait l'objet d'un avis aux autorités françaises ou ont été exécutées en France à la suite du transfèrement des personnes condamnées. 
لذلك يمكن - في اعتقادي- السماح للقاضـي الجنـائي بـالرجوع للقانون الجنـائي الأجنبي، للحم في الدعوى الجنائية المعروضـة أمامسه، حتى ولو أدي ذلك إلى تطبيق هذا القانون، طالمـا كـان ذلك أفضل لحسن سير العدالة، مـع التظلب على فكرة تنـازع السيادات التي تحاول دول كثيرة التمسك بها، وذلك عن طريق عقد الاتفاقيات الدولية، والنص عليه في القوانين الاخلية.

أهـا هوقـف المشرع المصري فلم ينص صر احة على ضرورة تطبيق القاضسي الجنائي للقانون الجنائي الأجنبي، فليس بالإمكان تطبيق هذا القانون - تحت أي صفة أو مبرر - داخل حدود الجمهوريـة. ومـع ذلك، فهذا لا يمنع من قيـام القاضـي الجنـائي بالرجوع للقانون الجنائي الأجنبي للحكم في الوقائع المعروضة أمامه، بل أنه ملزم في بعض الأحيان بالرجوع إليه للفصل في الاعوى، وإلا كان حكمه معيبا ومعرضا للإلغاء.

\section{والنصوص التي تتدد ضرورة الرجوع للقانون الجنائي الأجنبي :}

( ) نصت المادة الثالثة من قانون العقوبات المصري على أن "كل مصري ارتكب هو

في خارج القطر فعلا يعتبر جناية أو جنحة في هذا القانون، يعاقب بمقتضي أحكامه إذا عاد إلى القطر، وكان الفعل معاقباً عليه بمقتضي قانون البلا الذي ارتكبه فيه".

ونستخلص مـن النص السـابق، أن القاضـي الجنـائي الـوطني، إذا مـا عرضـت

أمامه دعوى بشأن ارتكاب مصري في خارج الإقليم فعلا يعد جناية أو جنحة في القانون المصري، وكان هذا الفعل معاقباً عليه في البلا الذي وقع فيهه، فأنـه سيكون ملزمـاً في هذه الحالة بالرجوع للقانون الجنائي الأجنبي الذي وقع في ظله الفعل الأثم، للتأكد من كونه مجرماً في هذا القانون من عدمه. 
وتظهر أهمية ذلك في مدي السير في نظر اللاعوى الجنائية المعروضـة أمسام

القاضي الجنائي الوطني من عدمهه، أو الحكم فيها، فبإذا ثبت ابتداء عدم تجريم الفعل الذي وقع في الخارج، فإن القضاء المصري لا يختص بالحكم فيه، حتى ولو كان معاقباً عليه طبقاً للقانون المصري.

Y) نصت المـادة (Y/Y) من قانون العقوبـات المصري، على أن "تسري أحكام هذا القانون على كل من ارتكب في خارج القطر فعلا يجعله فاعلاً أو شريكاً في جريمـة وقعت كلها أو بعضها في القطر المصري". فهذا النص يلزم القاضسي الجنـائي الـوطني بـرورة الرجـوع للقـانون الجنـائي الأجنبـي الـذي وقـع في ظلـه الفعل الإجرامي، سواء من الفاعل أو الثريك، ليتأكد من كون ذلك الفعل مجرماً.

$$
\text { ومن جماع ما سبق نخلص إلي الآتي: }
$$

أولا: ضـرورة العمل على تطبيق القاضـي الجنـائي للقـانون الجنـائي الأجنبـي، خاصة وأن هنـاك بعض الحالات الأساسية التي يضطر فيها القاضسي الجنائي لتطبيق هذه القوانين، رغم وجود صعوبات عديدة تقابله أثناء هذا التطبيق، مثل المشكلات المتعلقة بـاختلاف العقوبـات في تشريعات الدول المختلفة، وتمسكك بعض الدول بعدم تطبيق هذه القوانين بحجـة تعارضـها مـع السيادة الدوليـة. ويمكن التظلب عليها عن طريق عقد الاتفاقيات الدولية، كما يمكن التغلب على مشكلة اختلاف العقوبـات بين الدول، بعمل نظـام لمعادلـة العقوبـات عن طريـق الجداول المتماثلـة، مـع ضرورة نبذ الأفكار القديمة التي تتمسك بعدم تطبيق القوانين الجنائية الأجنبية، بحجة تعارضـها مع فكرة السيادة الدولية، طالمـا أن تطبيق هذه القوانين لا يخـالف النظسام العـام الداخلي للاولة. 
ثانيا: لا يجب أن يكون مبدأ إقليمية القوانين الجنائية المحور الأساسي لتطبيق

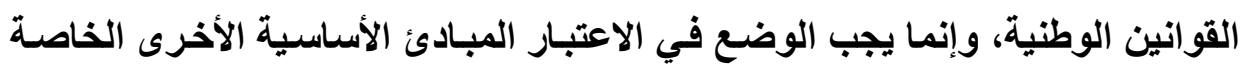

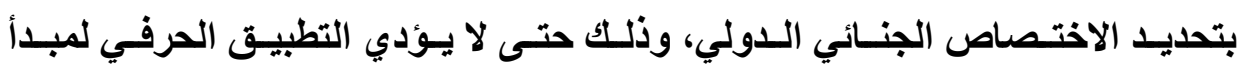

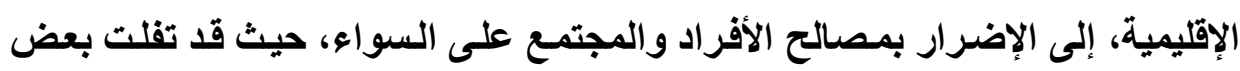
الجرائم المضرة بأمن الدولة من العقاب إذا ما وقعت خارجها، ولم تمتد إليها يد القانون

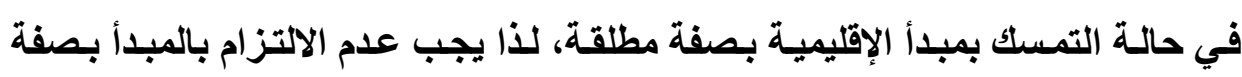
كاملة، ولكن يجب الاعتماد على غيره إلى جانبه، لضمان حسن سير العدالة.

فالمشرع الوطني يجب أن ينص صراحة على إمكانية تطبيق القوانين الجنائية

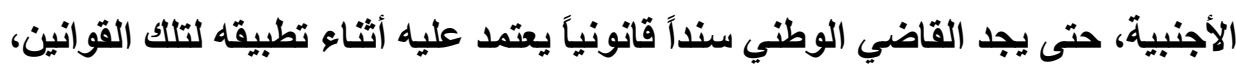

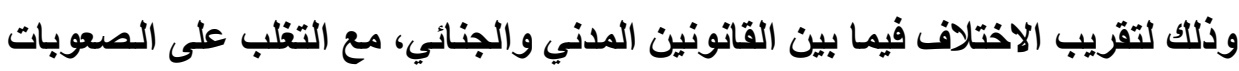

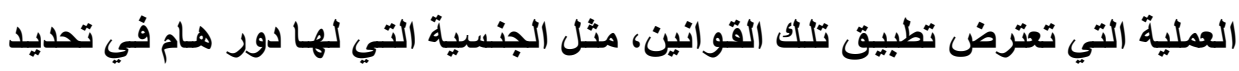
القانون الواجب التطبيق في الدعوى المعروضة أمام القضاء الوطني ('). ويمكن تطبيق القوانين الجنائية الأجنبية في حالات التعرض لنصوص القانون

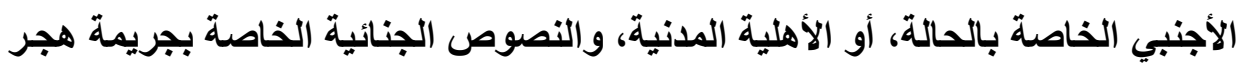

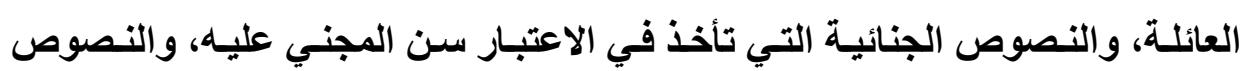

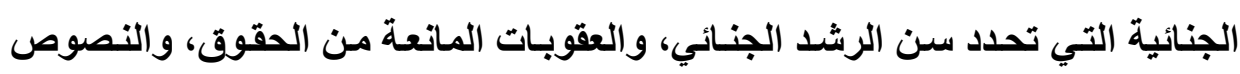

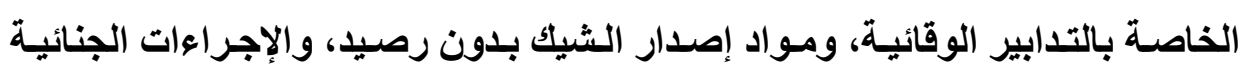
المتعلة بالثخصية الخطرة للمذنب.

(1) BOUREL., P. : Les conflits de lois en matiere d'obligations extracontractulles, Rennes 1959, L.G.D.J., Paris 1961.P.57. 
قد يتوقف المكم في اللدعوى الجنائية المعروضـة أمسام القاضسي الوطني، على ضرورة الرجوع للقانون الأجنبي لتحديد شروط وعناصر التجريم، ويدونها فإن الفعل المرتكب قد يخرج عن وصفه الإجرامي('). فتحديد الصفة الإجرامية للفعل عبر معرفة الحالة الثخصية للجنـاة تحدد مدي تطبيق القوانين الجنائية، بل أن الحكم في الدعوى الجنائية يوقف لحين البت في الحالة المدنيـة، والتي يتحدد على أسـاسـها تجريم الفعل من عدمـه. فالقـانون الجنـائي القابل للتطبيق لا يكون سارياً إلا بعد التحقق من سريان القانون المدني، والذي يحدد القانون الواجب التطبيق بنـاء على القـانون الوطني للأطراف. وبـذلك يمكن تطبيق القـانون الثخصي على عناصر التجريم، وتطبيق القانون الإقليمي فيمـا يتعلق بمقدار العقوبـة. فالجريمة التي نتجت عنها أضرار بالنسبة للرابطة الشخصية ـ كما في حالة مخالفة

(1) على سبيل المثال، فإن تحديد جريمة الزنا يوجب على القاضي الرجوع للقانون الثخصي للأطراف

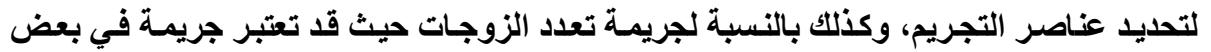

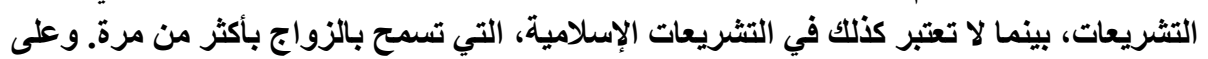

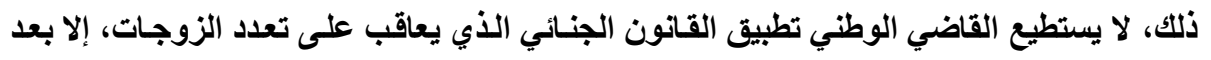

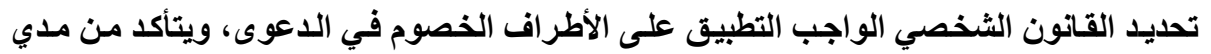

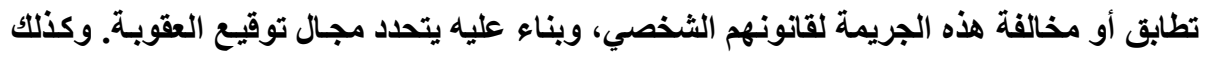

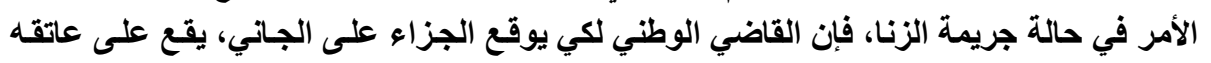

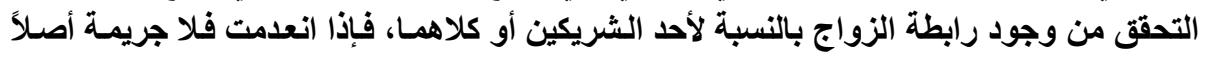

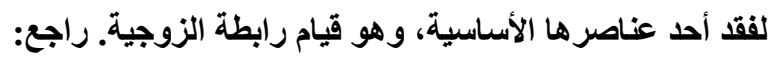

Trib.corr.brest, 18 octobre 1949, in R.S.C. , 1950, P.415.\& Paris, 21 mars.1949,J.C.P. ,1949, P.5163. 
نصوص عقد الزواج التـي تحرم الطلاق - ستحدد مقدار العقوبـة عليها بنـاء على النصوص القاتونية التي خولفت ، سواء أكاتت وطنية أم أجنبية(').

ومـن غير المعقول قبـول الأهليـة الجنائيـة التي تتعرض للتغير بطريقـة أكثر

سرعة، كما في حالة قيام شخص بعبور الحدود الدولية لإقليم دولة أخرى، حيث يجب التمسك أيضا بالأهلية المدنية لتحديد المسئولية الجنائية، في مثل هذه الحالة. وإذا كاتت غالبية التشريعات تعتمد في تحديد المسئولية الجنائية على ضرورة معرفة سن الجاني، إلا أن تحديد سن المجني عليه قد يكون له دور أساسي وفعال في تحديد تلك المسئولية،

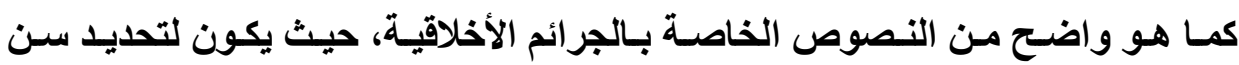
المجني عليه دور فعال في تحديد الوصف القانوني للواقعة من ناحية، وتحديد مسئولية

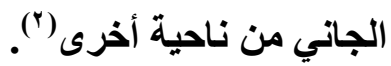
فالمشرع الانجليزي شدد العقاب على جريمة الاعتداء الجنسى على طفل دون r ا سنة؛ حيث يعاقب فى حالة الثروع بالسجن مدة لا تتجاوز ستة أشهر أو الغرامـة التى لا تتجاوز الحد الأقصى المقرر قانويًا أو كليهما، وفى حالـة الإدانـة النهائية يعاقب

(1) ومما يجدر ملاحظته أن الحالة الثخصية من وجهة النظر المنطقية، تحدد الحد الأدني للمسئولية

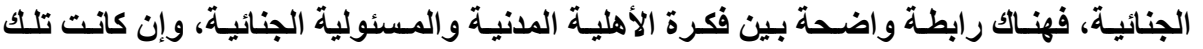

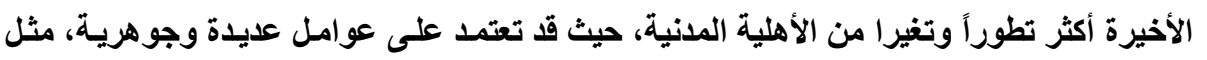

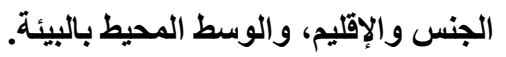

(2) DONNEDIEU DE VABRES, H. La competence universelle, Rapp. Français au IIIe. C.I.D.P., in actes du IIIe. C.I.D.P., Palerm, 3-8 avril 1932, XI, Roma, 1935, pp., 85 et. ss. 
بالسجن مدة لا تتجاوز أربعة عثر عامًا '). وأكد المشرع على ذلك فى الفقرة الثالثة من جريمة التسبب أو تحريض طفل دون با سنة على الاشترالك فى أنشطة جنسية بقولهه" إذا لـم ينتج عن تلك الأنشطة الواردة في الجريمـة مـا سبق ذكره فى الفقرة الخامسة مـن جريمـة التسبب فى ارتكاب أنشطة جنسية دون موافقة المجنى عليه، يعاقب مرتكب الجريمـة بالسجن مدة لا تتجـاوز ستة أشـهر أو الغرامـة التى لا تتجـاوز

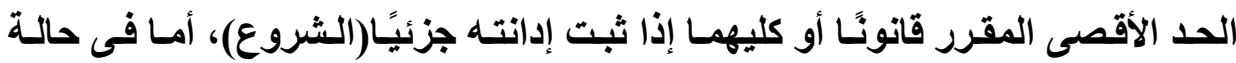
الإدانة النهائية يعاقب بالسجن مدة لا تتجاوز تتجاوز أربعة عشر عامًا (r).

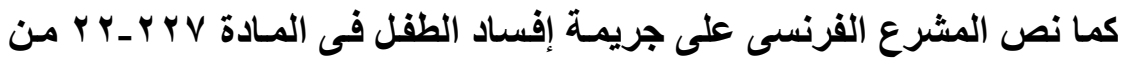

قانون العقوبات معدلة بالقانون الصادر فى V ل يونيو 991 19 بقولها يعاقب على تحبيذ أو الثروع فى تحبيذ إفساد الطقل بالحبس لمدة خمس سنوات والغرامة خمسمائة ألف

(1) Sexual Offences Act 2003 (c. 42) Part 1 - Sexual Offences Engaging in sexual activity in the presence of a child Sexual assault of a child under 13 (1) A person commits an offence if - (a) He intentionally touches another person, (b) The touching is sexual, and (c) The other person is under 13. (2) A person guilty of an offence under this section is liable(a) On summary conviction, to imprisonment for a term not exceeding 6 months or a fine not exceeding the statutory maximum or both; (b) On conviction on indictment, to imprisonment for a term not exceeding 14 years. \& G, R v [2009] EWCA Crim 265 (6 February 2009) \& Gaviria v R [2010] EWCA Crim 1693 (19 July 2010).



C. WELLS, O. QUICK, Reconstructing Criminal Law: Text and Materials, Cambridge University Press, 2010, P.541. C \& Ors, R v [2008] EWCA Crim 2790 (26 November 2008) \& Price, $R$ v [2008] EWCA Crim 1974 (31 July 2008). 
يورو. وثُشدد العقوبة إلى الحبس لمدة سبع سنوات والغرامـة سبعمائة ألف يورو إذا كان الطقل الذى وقعت عليه الجريمة يقل عمره عن خمس عشرة سنة، أو كان الطقل المجنى عليه قد وضع فى اتصال مع الفاعل بواسطة نشر رسائل عبر شبكة الاتصالات عن بعد، أو إذا ارتكب الجريمة داخل مدرسـة أو بمناسبة دخول أو خروج التلاميذ من

$$
\text { تلثك المدرسة أو بالقرب منها. }
$$

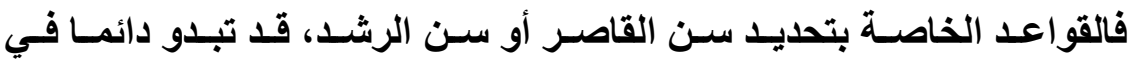
حالة تنـازع مستمر، لأن القواعد التي تحدد سن الرشـد الجنـائي تهدف أولاً إلى أمن وسلامة المجتمع، بينما تهدف القواعد التي تحدد سن الرشد المدني إلى حمايـة الأفراد في المقام الأول، ويمكن تجنب الآثار المترتبة على التصرفات الصادرة من القاصر بابططالها.

وتظهر الصعوبة في فهم وإدراك مضمون القانون الجنـائي الذي وضع لحمايـة

المجتمـع والجـاني على السواء، فسن الرشـد الجنـائي غالبـاً مـا يتحدد طبقاً للقوانين الإقليميـة، والتمسك بـالقوانين الأجنبية في هذا الشأن، قد يتعـارض مـع النظـام العـام الاولي في حالة تحديد سن الرشد بأكثر من ثمانية عشر عاماً، لذا يجب اقتصار تطبيق القوانين الجنائية الأجنبية على الأجانب. ويري الفقه الحديث ضرورة تحديد سن الرشد بإحدى وعشرين عاماً، وذلك لحماية الجاني من المؤثرات التي قـ تؤدي به إلى السقوط في الهاوية مستقبلا، باختلاطه بمعتـادي الإجرام. وإن كـان ذلك قد يؤدي إلى الإضرار

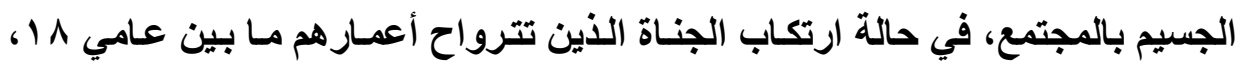
ا Y عاماً للعديد من الجرائم الخطرة، وتوقيع عقوبة مخفقة عليهم، مما قد يكون لـه أثر في انتثار الجريمة من هؤلاء الجناة. 
ونشير هنا إلي الحكمة من اختلاف سن الرشد الجنائي عن سن الرشد المدني

تكمن في أن سن الرشد الجنائي يكفي لاكتماله التمييز وحرية الاختيار، في حين لا يكفي ذلك لاكتمال الرشد المدني، حيث قد يتطلب الأخير توافر قدر من الخبرة بالمعاملات وهو مالا يتوافر إلا في سن متأخرة. أما العقوبـات المانعة من الحقوق فيقصد بها الحرمـان من بعض الحقوق والمزايا على نحو يضيق من دائرة نشاط المحكوم عليه في المجتمع، وهو يعنى عدم ثقة المجتمع في المحكوم عليه('). والغالبية العظمي للعقوبات الجنائية ـ الأصلية منها والتبعية ـ تخضع للقانون الإقليمي لها، سواء بالنسبة لعقوبـة الإعدام، أو العقوبـات السالبة للحريـة أو العقوبـات المالية، أو بالنسبة للعقوبات التبعية كالحرمان من مباثرة الحقوق الوطنية، والحرمـان من بعض الحقوق المدنية والعائلية، كسقوط الحق في الولايـة الأبويـة، وخفض الأهلية المدنية، وهذه العقوبـات تلحق بالحالة العائليـة والتي تخضع بحسب الأصل للقـانون الشخصي للجـاني، ومـع ذلك فأنها تتبع القوانين الجنائيـة الوطنيـة، نظراً لارتباطها بالعقوبات الجنائية الأصلية. ولقد استوحت أحكام القضاء الفرنسي فكرة تطبيق القوانين الوطنية على تلك العقوبات بقبول العقوبات التبعية المتماثلة، والملازمة لعقوبة سـالبة للحريـة أو لعقوبة الإعدام، حيث تخضع تلكك العقوبات التبعية لنفس القانون الذي يحكم بالعقوبات الأصلية،

(1) DONNEDIEU DE VABRES, H. La competence universelle, Rapp. Français au IIIe. C.I.D.P., in actes du IIIe. C.I.D.P., Palerm, 3-8 avril 1932, XI, Roma, 1935, pp., ץ · et. ss. 
وترتبط بهـا بطريقة آليـة، وذلك مثل الحجر القـانوني الذي قـ يـلازم تنفيذ العقوبـات

الأصلية الأكثر شدة(')

فحالات سقوط الحقوق والتي تخضع للقانون الإقليمي، تختلف عن حالات عدم

الأهلية والتي تخضع للقوانين الثخصية للجاني، فالأولي يظهر فيها عدم ثقة المشرع

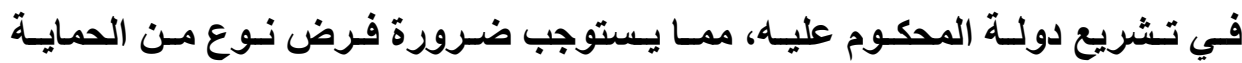
الاجتماعيـة الفعالـة في مواجهة المـنب، وتحقيق مصلحة المجتمع، بينمـا تظهر في الحالة الثانية فكرة الحماية الثخصية للثخص المحمي.

أما النصوص الخاصة بالتدابير الوقائية وتعنى مجموعة الإجراعات التي تواجه

خطورة إجرامية كامنة في شخص مرتكب الجريمة، لتدرأها عن المجتمع، وانطلاقاً من هـذه النقطـة، الدولـة التـي تتسلم المــنب لتوقيـع إجـراء أو تــبير احتـرازي، تتعهـ بمسئوليتها الكاملة في مواجهة الدولة المسلمة، بالعمل على توقيع التدابير الاحترازيـة المناسبة ضـده، والغرض مـن ذلكت هو حمايـة المجتمع بمكافــة الإجرام مـن ناحيـة، وحماية المذنب من حيث تقويمه وإصـلاحه من ناحية أخرى، ليعود بـالنفع في النهايـة على المجتمع. وهذه هي الاعتبارات التي تنـادي بها السياسة الجنائية الحديثة بصفة

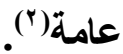

(1) DONNEDIEU DE VABRES, H. La competence universelle, Rapp. Français au IIIe. C.I.D.P., in actes du IIIe. C.I.D.P., Palerm, 3-8 avril 1932, XI, Roma, 1935, pp., $r \cdot r$ et. ss.

(2) SAUER, W. : Le probleme de l'unification des peines et des mesures de surte, in R.I.D.P. 1953, PP. 601 et. ss. 
وإزاء ذلكت يمكن تطبيثق القـانون الشخصي للمـنتب بالنسبة للتـابير الأمنيـة الوقائيسة. فتلك التـابير الاحترازيـة الخاصـة بتوقيع عقوبـة معينـة ضــ الحالـة الخطرة للمجرم، تهدف في الجزء الأكبر منها إلى مواجهته، وهذه الإجراعات التي تفرضها اعتبارات الدفاع الاجتماعي، تستلزم ضرورة تطبيق القانون الإقليمي المختص بوقوع الجريمة، بصرف النظر عن الدولة التي يحاكم أمامها ذلك المجرم. كمـا يمكن قبول قـانون القاضسي الذي قد ينيب عن القانون الشخصي للمذنب بصفة استثنائية، دفاعاً عن النظام العام، وذلك بغية توقيع الإجراعات الوقائية ضد خطر ذللك المجرم، خاصة إذا ما كان على درجة كبيرة من الإجرام. ونشير هنـا إلى مـا نصت عليه المـادة هب من قانون العقوبـات اللبنـاني حول التطبيتق الاحتمـالي للقـانون الجزائسي الأجنبـي بتقريرهـا أنـها : "إذا اختلفت الشريعة اللبنانية وشريعة مكان الجرم فللقاضي عند تطبيقه الشريعة اللبنانية وفاقًاً للمسادتين الـ

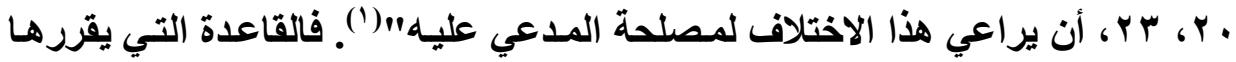
هذا النص تقضي بمراعاة الاختلاف بين القانون اللبنـاني وقانون الإقليم الذي ارتكبت فيه الجريمة لمصلحة المدعي عليه، ويعنى ذلك أن على القاضي المقارنة بين القانونين وتحديد أصلحهما للمدعي عليه سواء من حيث التجريم أو العقاب وتطبيقه وحده دون

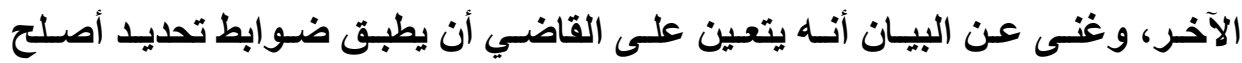
القانونين للمدعي عليه. ولكن يجوز للقاضي أن يستخرج من القانون الأجنبي الأحكام

(1) يبدو من مظاهر النص أن الأمر اختياري للقاضي: فله أن يفيل المدعي عليه من هذا الاختلاف أو لا

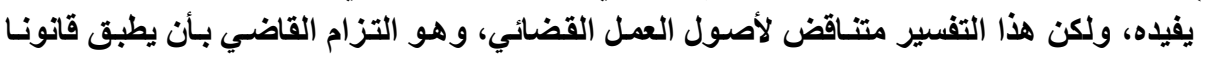

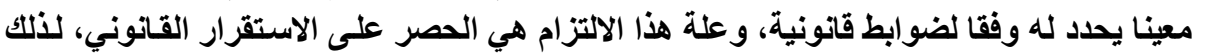
نري تفسير هذا النص في معنى التزام القاضي بتطبيق أصلح القانونين للمدعي عليه. 
التي هي في مصلحة المدعي عليه ويجمع بينها وبين القانون اللبناني، بشرط أن تتسق معه فيكون وإياها تنظيماً تشريعياً متكـاملاً ، أمسا إذا لم تتسق معه فـلا مفر من تطبيق أصلح القانونين وحده.

ولم يجعل المشرع هذا التطبيق الاحتمـالي مطلقاً فـأورد قيداً متعلقًاً "بتــابير

الاحتـراز أو الإصـلاح وفقدان الأهليـة والإسـقاط مـن الحقوق المنصوص عليهـا في الشريعة اللبنانيـة" يقضي بعدم الاعتـاد في شـأنها بقـانون الإقليم الذي ارتكبت فيـه

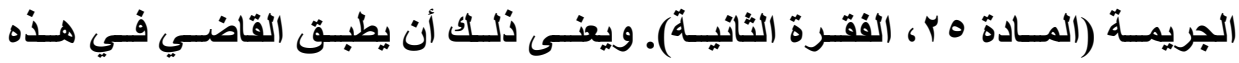
الموضوعات القـانون اللبنـاني بكل مـا يقضي بـه من أحكام ولو كـان القانون الأجنبي يجهاهـا، أو لا يقررهـا في الحالـة التي ارتكب فيها المدعي عليه جريمتهه أو يخضعها لأحكام مختلفة. وعلـة هذا القيد أن هذه التدابير - ومـا يلحق بها ـ تستهذف حمايـة المجتمع اللبناني من خطورة جريمة تهدده، فلا يجوز أن يرتهن تطبقها بنصوص قانون أجنبي لم تراع فيها مقتضيات حماية هذا المجتمع ('). ونخلص من ذلك إلى الاعتراف بأن تطور القاتون الجنائي الدولي، أعطي الحق في تطبيق القوانين الأجنبية الخاصة بشخصية الجاني أو المجني عليه، على الرغم من أن ذلك قد لا يتحقق إلا في فروض نـادرة، فغالبيـة القوانين الجنائية تهدف إلى حمايـة المجتمع، والتي قد لا تتحقق إلا بتطبيق مبدأ إقليمية القوانين الجنائية بصفة أصلية، مع عدم التمسك بحرفية المبدأ صيانة لحسن إدارة العدالة.

( ) راجع فى تفصيل ذلك؛: د/محمود نجيب حسنى، شرح قانون العقوبات اللبناني، القسم العام، الطبعة

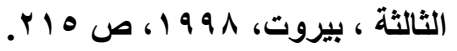




\section{تطبيق القانون الأجنبي طبقا للقانون المصري (الأخذ في الاعتبار):}

لا يجيز قانون العقوبـات الحسالي للقاضسي أن يطبق قانونـاً أجنبيـا ولـو ارتكبت

الجريمة في الخارج وكان مرتكبها أجنبيا. ولكنه يلزم القاضسي في حالات محدودة بـأن يأخذ في الاعتبار ما يقرره القانون الأجنبي كي يصل بذلك إلى تطبيق القواعد الوطنية على نحو معين: مثال ذلك اشتراط كون الفعل الذي يرتكبه مصري في الخـارج معاقبا عليه طبقا للقانون الساري في الإقليم الذي ارتكب فيه (المادة ب من قانون العقوبـات)، وعدم جواز إقامة الاعوى ضد من ارتكب جريمة أو فعلا في الخارج إذا ثبث أن المحاكم الأجنبية قد برأتهه أو أدانته نهائياً واستوفي عقوبته (المـادة ؛ من قانون العقوبـات)، وهـا الحكم يـصدر بطبيعـة الحسال تطبيقـاً للقـانون الأجنبـي، والحالتــان السـابقتان لا تنطويـان على تطبيق للقـانون الأجنبـ، و إنمـا تنطويـان على مجرد أخذ لأحكامـه في الاعتبار كي يطبق القانون المصري على نحو معين. يتجه فريق من الفقه الحديث، إلى أنه إذا كان لا يمكن بحال، التضحية بالأسس التي يقوم عليها التطبيق القاصر أو المـانع للقانون الجنائي الوطني، إلا أن مقتضيات حسن أداء العدالة، والتطبيق السليم للقانون الوطني، قد تستثزم الرجوع إلى القانون الجنائي الأجنبي، كقانون الدولة التي وقعت فيها الجريمـة. وهذا الرجوع إلى القانون الجنائي الأجنبي لا يعنى التطبيق الفعلي له، و إنما فقط أخذه في الاعتبار أو استشارته، فيجب عدم الخلط بين التطبيق وبين الأخذ في الاعتبار ('). 
وفكرة الأخذ في الاعتبار يتبناها فريق من فقهاء القانون الدولي الخـاص، بشأن مركز القانون العام الأجنبي أمام القضاء الوطني(') حيث يستعير أنصار فكرة "الأخذ في الاعتبار" أمثلة مستندة من التشريع، نكتفي بذكر مثالين:

الأول : مـا نصت عليـه الفقرة الثانيـة من المسادة 9 آج من قـانون الإجراءات

الجنائية الفرنسي، بخصوص مبدأ الثخصية الإيجابية، فكل فرنسي ارتكب وهو خـارج فرنسا جنحة ضد أحاد الأفراد يعاقب بمقتضي أحكام قانون العقوبـات الفرنسي، بشرط أن يكون الفعل معاقبا عليه في قانون الدولة التي ارتكب فيها. وهو ما يقابل نص المـادة

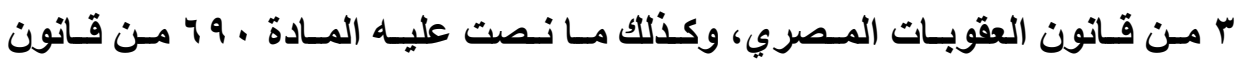
الإجراعات الفرنسي من اختصاص المحاكم الفرنسية بالعقاب على أعمال الاشثراك التي تتم في فرنسا. بشأن الجنايـات والجنح التي ترتكب في الخـارج، وذلك إذا كـان الفعل الأصلي معاقباً عليه في القانون الفرنسي وفي قانون الدولة التي ارتكب فيها، وكانت الجناية أو الجنحة قد ثبتت بحكم نهائي من جانب قضاء تلكك الدولة. فقي هذه الحالـة وسـابقتها، يلزم إزدواج التجريم بين قانون القاضسي وقانون العقوبـات في الدولـة التي ارتكبث فيها الجريمة.

الثاني: ما أورده المشرع الفرنسي والمشرع المصري من بين قيود تحريك اللدعوى الجنائيـة عن الجرائم التي ترتكب في الخـارج. فقد قررا أنـه لا تجوز إقامـة

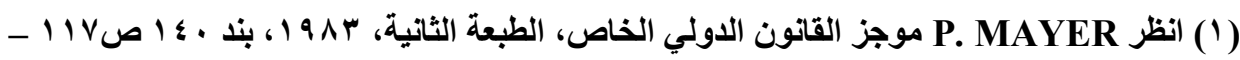

F.RIGAUX : Precis de Droit international prive, Bruxelles 1968, n. 137 p. 192; Meme auteur : Droit public et droit prive dans les relations internationales, Paris - Pedone, 1977, n. 79. c. 
الدعوى الجنائية ضد مرتكب الجريمة في الخارج، إذا ثبت أن المحاكم الأجنبية قد برأته مما أسند إليه، أو أنها حكمت عليه نهائياً واستوفي عقوبته (المـادة ب ج 7 من قانون الإجراءات الجنائية الفرنسي، والمادة ؛ من قانون العقوبات المصري). فقي هذه الأمثلة، وغيرهـا، لا يطبق القاضسي الوطني قانون العقوبـات الأجنبي للاولة التي وقعت فيها الجريمة، بل يأخذه، فقط، في الحسبان، ويستثيره للتعرف على معاقبته على العمل من عدمـه، أو على تبرأته للمتهم ممـا أسند إليسه('). أو كمـا يقول جاتب من الفقه المصري المناصر لهذا الرأي " لا يجيز قانون العقوبات الحالي للقاضي أن يطبق قانونـا أجنبياً ولـو ارتكبت الجريمـة في الخـارج وكـان مرتكبها أجنبياً. ولكنـه يلزم القاضي في حالات محددة بأن يأخذ في الاعتبار ما يقرره القانون الأجنبي كي يصل بذلكك إلى تطبيق القواعد الوطنيـة على نحو معين". ويضيف صـاحب هذا الرأي أن الحالتان السابقتان، لا تنطويان على تطبيق للقانون الأجنبي. وإنما تنطويان على مجرد أخذ لأحكامه في الاعتبار كي يطبق القانون المصري على نحو معين"(). وحول مدي صحة الأمثلة التي استند إليها الفقه للقول بأن الأمر يتعلق فقط بأخذ القانون الجنائي الأجنبي في الاعتبار. يمكن القول بخصوص المثال الأول أن استلزام المشرع العقاب على العمل الذي ارتكبه الوطني في الخـارج، وفقا لقانون الدولـة التي

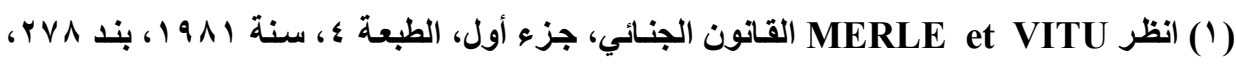

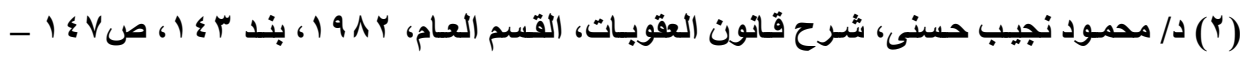

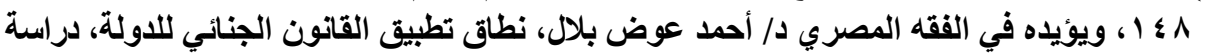

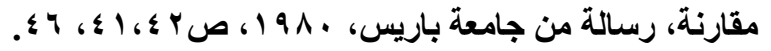


وقع فيها ذلك العمل، لا يعنى أن القاضي يأخذ القانون الأجنبي في الاعتبار فقط('). إلا أن الأمر يتعلق في المثال السابق، بتطبيق فعلى للقانون الأجنبي، وليس بمجرد أخذه في الاعتبار أو استشـارته. لأنه إذا كـان المشرع الوطني استلزم تجريم العدل والعقاب عليه في القانون الجنائي الأجنبي، فهو بذلك قد أراد أن يدخل هذا الأخير مـع القانون الوطني في تكوين شروط انطباق القاعدة الجنائية وبعبارة أخرى أراد المشرع الجمع في نطاق الركن الشرعي بين قاعدة سلوك أجنبي وقاعدة عقاب وطنيـة ولا انفصال لأحدهما عن الأخرى في شـأن الاختصاص الشخصي. فالقاضي الوطني يخـاف مبدأ الشرعية الجنائية إذا أهمل القانون الأجنبي لاولة محل ارتكـاب العمل غير المشروع واكتفي بقانونه وأنزل العقاب بالفعل(؟). أمسا بخصوص المثال الثاني وهو عدم جواز إقامـة الدعوى الجنائية على من يثبت أن المحاكم الأجنبية قد برأته مما أسند إليه أو حكم عليه نهائيا واستوفي عقوبته بشأن الجرائم التي ارتكبها في الخارج، فالأمر لا يقتصر على مجرد أخذ الحكم الأجنبي

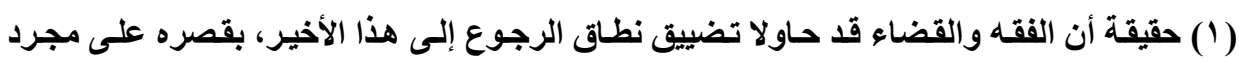

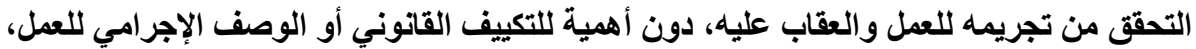

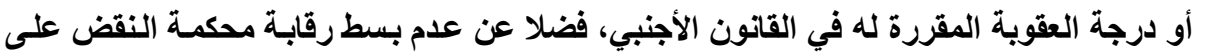
تقفير والكثف عن مضمون القانون الأجنبي. (ץ) قارب في هذا المعنى J, STOUFFLET : التقرير السابق في المجلة الدولية لقانون العقوبات،

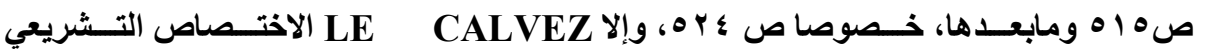

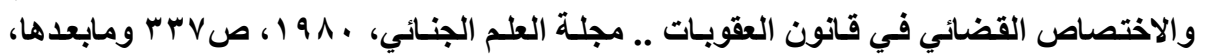

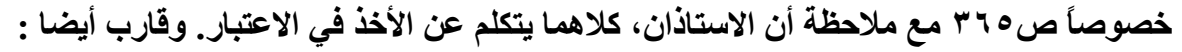

G. FUNARO :L'applicationde la loi penale etrangere par le juge national.

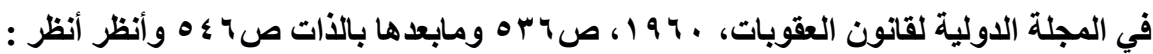
H. DONNEDIEU de VABRES; les principes modernes p. 174. 
في الاعتبار أو أخذ حجيته السلبية في الحسبان، بل نكون أمسام تطبيق فعلي للقانون الأجنبي. لأنه إذا ثبت أن الحكم الأجنبي يقرر براءة المتهم أو إدانته واستيفاء عقوبتهه، فلا اختصاص للقانون الجنائي الوطني، ولا للمحاكم الجنائية الوطنية. ولا يصح الادعاء بأن الأمر يتعلق باعتر اف بحجية الأمر المقضي السلبية للحكم الأجنبي، فهذا الاعتراف مـا هـو إلا إعمـال للقـانون الأجنبـي لأن الحكم يـدر تطبيقاً لأحكـام القـانون الجنـائي الأجنبي.

ويشأن فكرة الأخذ في الاعتبار ذاتها يمكن القول أن الزعم بأن القاضي لا يطبق قاعدة ما، بل يأخذها في الاعتبار أو الحسبان فقط فهو يعنى أن القاضسي في حل من تطبيقها أو الالتزام بها. وهذا مالا يجوز ('). والقول كذلك بأن القاعدة القانونية إذا كانت تنتمي إلى قانون دولة أجنبيـة، تتجرد من عنصر الأمر أو الإلزام فيها، بحيث تصبح مجرد واقعة كما يزعم جاتب من الفقهـ الفرنسي()، فالقانون الأجنبي يجب أن يوضع على قدم المساواة مع القانون الوطني. بل وعلى فرض تجرد قواعده من صفة الإلزام بعبورها الحدود، فلا تلبث أن تسترد تلك الصفة بنـاء على أمر المشرع الوطني إلى القاضي بتطبيق القانون الأجنبي ().

D.LOUKITCH : La force obligatoire de la norme juridique et le probleme d'un droit objectif. The e, paris, 1939.

جز H. BATIFFOL : Aspects philosophiques (r)

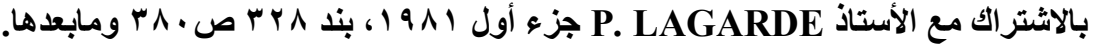

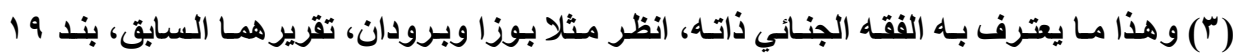

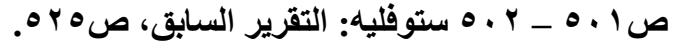


ومن ناحيـة ثانية، نلاحظ انعدام الفرق "الأخذ في الاعتبار" و "التطبيق"،

فالأمر في الحالتين واحد. فأخذ القاضسي القاعدة في اعتباره، وتكوين عقيدته اللازمـة لإصدار الحكم ورد العدالة بناء على ذلك، يعنى في الحقيقة أنه يطبق حكمها، وإلا فمـاذا

$$
\text { يعنى تطبيق القانون عموماً؟(') }
$$

خلاصة ما سبق أن المشرع لم بطرح على نحو كامل، القانون الأجنبي واجب

التطبيق. فقضلا عن أن الأمر لا يتعلق في شـأن الاختصاص الشخصي، إلا باختصاص احتياطي فقد قدر المشرع أن اختصاص قانونه الوطني واهن الأسـاس لأن الاختصاص الأصيل، في هذا الفرض، يثبت للنظام القانوني الأجنبي لاولـة محل ارتكاب الجريمـة ـ حفظا توقعات الأفراد، لأن من البديهي أن يتوقع المتهم محاكمته وفقا لقانون الدولـة التي اقترف على إقليمها جريمته(؟) وتطبيق قانون القاضي، على خلاف ذللك، يهدر تلك التوقعـات(") ـ فقرر ضـرورة الرجـوع إلـى هــا النظـام الأخير، بحيث لا يجـوز انعقــاد

(1) انظر الأستاذ M. BAUER رسـالة في القانون العام الأجنبي أمسام القاضي الوطني... السالفة الأكر، جزء أول، بند وه ص كذلك الأستاذة :

F. DEBY - GERARD: Le role de la regle de conflit dans le reglement des rapports intednationaux.

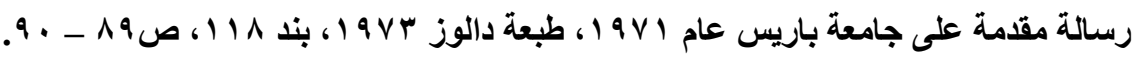

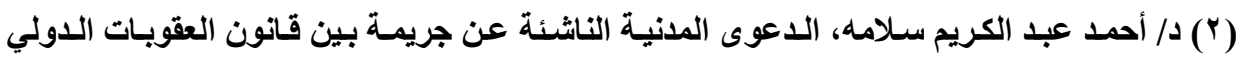

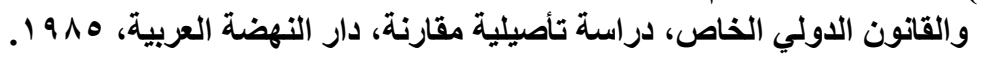

M. N. JOBADR-BACHELLIER : L'aparence en droit international prive, These, paris, 1983, ed. L.G.D.J., 1984.

راجع في هذا المعنى : أستاذنا P. MAYER موجز القانون الدولي الخاص، الطبعة الثانية،

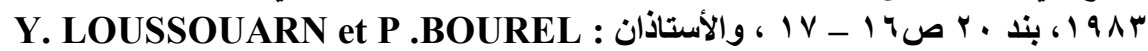

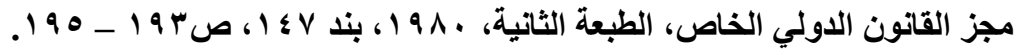


الاختصاص التشريعي لقانونـه، والاختصاص القضائي للمحاكمـة، إذا كان العمل الذي أتاه أحد الوطنيين غير مجرم وغير معاقب عليه في القانون المحلي صاحب الاختصاص الأصيل. فالأمر لا يقتصر على مجرد أخذ لهذا القانون الأجنبي في الاعتبار بـل يتعلق الأمر بتطبيق فعلي له.

لذلك يمكن تطبيق القاضسي الوطني للقانون الجنـائي الأجنبي عبر التمييز بين قوانين الحماية الاجتماعية ـ كالقوانين الجنائية الإقليمية ـ وقوانين الحمايـة الفرديـة ـ كـالقوانين الجنائية الثخصية ـ وذلك عن طريق تحليل الهـف أو الغايـة الاجتماعيـة للقانون. فإذا كان النوع الأول يتسم بالعموميـة في التطبيق وذا نطاق إقليمي، يسري على كل الأشخاص والوقائع في الإقليم. فبإن النوع الثاني يتسم بالاستمرار أي ممتـ التطبيق، ويسري على علاقات الأفراد ويتبعهم حتى خارج الحدود ('). أما القول بعدم إمكان تطبيق القاضسي الوطني للقانون الجنائي الأجنبي، يرجع إلى الخطأ في فهم معنى الإقليمية في تطبيق القوانين، وتحميل هذا الإصطلاح بمـا لا يطيق وما يخرج عن مضمونه الحقيقي. فالقانون الإقليمي هو القانون الذي يطبق على

(1) A. PILlET : Traite pratique de droit international prive t. 1, paris. 1923, n. 37. p. 115; Meme auteur : Principes de droit international privd, paris-Grenoble, 1903, N. 130, p. 285 et ss.

الظر هنرى دوند بودي فابر : محاولة لنظام منطقي لتوزيع الاختصاص ..... مقال منشور بالمجلة

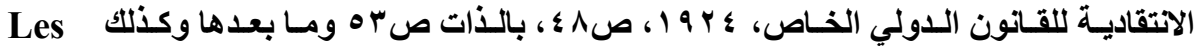

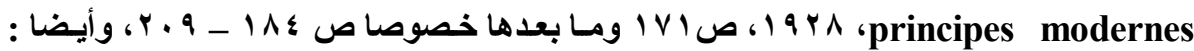

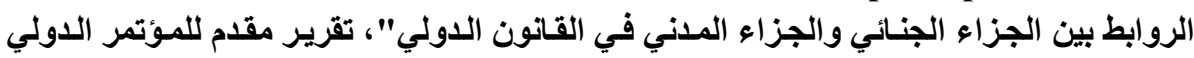

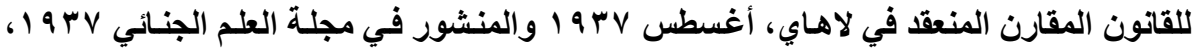

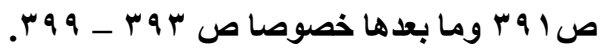


ما يحدث على الإقليم، وليس مطلقاً هو القانون الذي لا يمكن تطبيقه بواسطة قاض دولة أجنبية(') فلا يوجد ما يمنع من تطبيق القاضي الوطني للقانون الأجنبي على مـا تم من وقائع على الإقليم الذي يسري فيه.

فالإقليمية كمبدأ لا تحول مطلقا دون تطبيق القاضسي الوطني للقوانين الأجنبية

على الوقائع والتصرفات التي تمـت في الخـارج، على الإقلّيم الذي تسري فيـه تلكـ القوانين، أما الادعاء بأنها تعنى عدم نفاذ قانون الدولة خارج حدودها. فهو إدعاء باطل أمام مقتضيات حتمية التعاون الدولي وضرورات الحياة القانونية الدولية ومن هنا كانت ضرورة التخفيف عن غلواء التلازم بين الاختصاص القضائي والاختصاص التشريعي، والسماح بتطبيق القانون الأجنبي من قبل القاضي الوطني ().

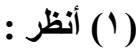

A. TOUBIANA : Le domaine de la loi du contrat en Droit international prive (contrats internationauv et dirigisme etatique).

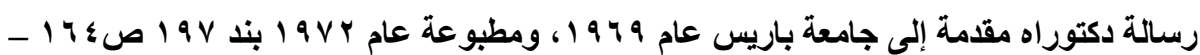
19 19

"Une loi territoriale n'est pas une loi qui ne peut pas etre appliqué par un juge etranger mais une loi qui appliqué a tous lee Faits qui se deroulent totalement ou meme partiellement sur le territoire"

وفي نفس المعنى MAUER، BAU رسالته في مركز القانون العام الأجنبي أمام المبادئ الحديثة ..

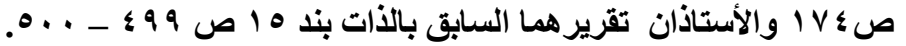

\section{H.DONNEDIER de VABRES BOUZAT et BREDIN}

(2) E. M. MEIJERS : l'histoire des principes Fondamentaux du Droit international prive, Rec, cours la Haye, 1934, t. III, p. 595, Meme auteur : Etudes d'histoire du droit iternational prive, paris, 1967, p. 64. 
فالقول بأن الإقليمية تعنى عدم تطبيق القانون الأجنبي، ينطوي على خلط غير

جائز ببين الإقليميـة الماديـة والإقليميـة الإجرائية لقواعد القـانون الأجنبـي. فبإذا كانـت الأولي تعنى تطبيق القانون الأجنبـي على إقلّم الدولـة التي وضعته، فِان الثانيـة تعنى إمكان تطبيق ذلك القانون من قبل محاكم الدول الأخرى على الوقائع والتصرفات التي تلخل مجال سريانه('). بل إن الإقليمية بهذا المعنى الثاني، إذا أحسنت النظم القانونيـة فهمها، فسوف تؤدي إلى الوصول إلى عالمية حلول القـانون الدولي(؟) ، إذ ستقتح الباب لتطبيق القاضـي الوطني للقـانون الأجنبـ، طالمـا كـان هو القانون الملانم لحكم النزاع، دون مـا نظر إلى صفة هذا القانون(") ـ فمبدأ الإقليميـة لا يعنى هجر تطبيق مئي القانون الجنائي الأجنبي.

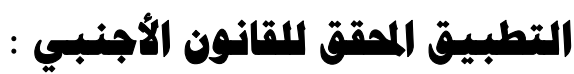

يمكن أن يكون تطبيق القانون الأجنبي محققا إذا نص على ذلك من خلال الأخذ في الاعتبار قانون المدعي عليه الذي ينظم أحوالهه الشخصية أو أهليته، وهو مـا نص

(1) K. NEUMEYER : Autonomie de la volontd et dispositions imperatives en droit international prive des obligations

$$
\begin{aligned}
& \text { في المجلة الاتتقادية للقانون الدولي الخاص، } 19 \text { ه 1، صبه ومابعدها، بالذات صץ V V. }
\end{aligned}
$$

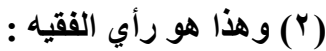

J. - P. NIBOYET : L'universalite des regle de solutions des conflits est realizable sur la base de la territorialite;

$$
\begin{aligned}
& \text { في المجلة الاتتقادية للقانون الدولي الخاص، . ه } 19 \text { ، ص9 ـ ه ومابعدها. }
\end{aligned}
$$

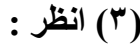

P. LEPAULLE : Le droit international privd, ses bases; ses norms et ses methode, paris - DALLOZ, 1948, P. 25-26. 
عليه المشرع اللبنـانى في المـادة ج ب من قانون العقوبـات التى تنص على أنها "فيمـا خص الجرائم المقترفة في لبنان أو في الخارج تراعي شريعة المدعي عليه الثخصية

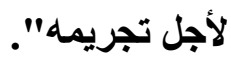

ا - عندما يكون أحد العناصر المؤلفة للجرم خاضعاً لثريعة خاصة بالأحوال الثخصية

$$
\text { أو الأهلية. }
$$

r - عندما يكون أحد أسباب التثديد أو الأعذار الثرعية ماعدا القصر الجزائي ناشئًا عن شريعة خاصة بالأحوال الثخصية أو بالأهلية.

ومن النص يتضح قصور ذلك على مجالين أساسيين: الأول: هو تحديد أركـان الجريمـة المسندة إليه، والثاني، هو تحديـ مـا إذا كـان سبب لتشديد العقـاب أو عذر قانوني - عدا القصر الجزائسي- متوافراً أم غير متوافر. فـإذا كـان هدف المشرع هو تطبيق القانون على أفضل نحو تتحقق به العدالة والحمايـة الاجتماعية معاً الأمر الذي يلزم معه تطبيق قانون المدعي عليه في هذين المجالين سواء كان لمصلحته أو في غير مصلحته، فليس الهذف من هذا النص التخفيف عن المداعي عليه، وإنمـا الهـف منـه إخضاع أركان الجريمة واعتبارات تقدير العقوبة لقانونها الطبيعي.

كما أنه ليس مراد المشرع في هذا النص إفساح المجال لتطبيق القانون الأجنبي فحسب، بـل إن هذا النص قد يحيل على قانون خـاص بـالأحوال الشخصية أو الأهلية مطبق في لبنـان ويتحدد وفقاً للطائفة التي ينتمـي إليهـا المدعي عليهـ. والمجـال الأول لتطبيق قانون الأحوال الثخصية(1) أو الأهلية هو تحديد أركان الجريمة، سواء كان من (1) دمحمود نجيب حسنى، شرح قانون العقوبات اللبنـاني، القسم العام، الطبعة الثالثة ، بيروت، 
شأن ذلك إثبات توافر هذه الأركان أو نفيها، ويفترض ذلكك أن القول بتوافر الركن أو انتفائه متوقف على تطبيق قاعدة قانونية تنتمي لقانون الأحوال الثخصية أو الأهلية، مثال ذلك أن يلاحق شخص بالزنا فيثور البحث في توافر ركن "قيام الزوجية" بينه وبين شخص آخر غير شريكه في جريمته، فيقتضي ذلكت الرجع إلى قانون أحوالـه الثخصية لمعرفة ما إذا كاتت هذه الزوجية تعتبر قائمة أم غير قائمة. أما المجال الثاني لتطبيق هذا القانون، فهو التحقق من توافر الأسباب المشددة أو الأعذار، مثال ذلك أن يعتبر المشرع كون المدعي عليه أصلاً أو فرعاً أو زوجاً للمجني عليه سبياً لتشديد عقابه أو تخفيفه وجوبا أو إعفائه منه، فيكون متعينا الرجوع إلى قانونـه لتحديد مـا إذا كاتت هذه الصلة متو افرة على النحو الذي يفترضه القانون. وقد استبعد الثشارع القصر الجزائي من نطاق تطبيق القانون الثخصي، مما يغنى خضوعه للقانون اللبناني دائمسا أيا كاتت جنسية المدعي عليه أو طائفته. وعلة هذا الاستبعاد أن القصر الجزائي نظام قانوني يصدر عن سياسـة جنائية معينة في مكافحة انحراف الأحداث، وهي سياسـة تختلف من تثريع إلى آخر، فلم يشأ المشرع أن يسمح بتطبيق تشريع أجنبي أو إدخال عناصر غريبة على القانون اللبناني، خثية أن يفسد ذلك السياسة الجنائية اللبنانية في

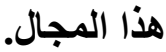

\section{المطاب الثاني}

\section{شروط تطبيق القانون الجناني الأجنبي}

يمكن تطبيق القـانون الجنـائي الأجنبي في حالـة مـا إذا كـان القـانون الجنـائي الأجنبي غير قابل للتطبيق، سواء لانعدام التجريم أو بسبب القواعد التي تحدد مجال 
تطبيـق التشريع الجنـائي لهـذه الــلـل أو في حالـة عـدم اختصاص قـانون القاضسي المعروض أمامه النزاع فسيطبق القانون الأجنبي الذي وقعت في ظله الجريمـة بصرف النظر عما إذا كان التسليم مستحيلا أم لا ويكون ذلك بطلب من الدولة التي وقعت عليها الجريمة أو التي أصيبت مصالحها بأضرار (').

وفي حالة تطبيق القانون الجنائي الأجنبي، يجب على القاضي أن يكيف الواقعة بالوصف المناسب طبقاً لقانون محل ارتكابها، وإلا تعرض حكمة للإلغاء من المحكمة العليا في الدولة التي أصدرث الحكم. وفي حالة تطبق القاضي الجنائي لقانونـه الوطني ـ طبقاً لمبدأ الثخصية ـ على الواقعة المرتكبة بالخـارج، فيجب أن يضع في اعتباره القانون الأجنبي الأصلح للمتهم مـع استبعاد تطبيقه إذا كـان متعارضـا مـع النظـام العام

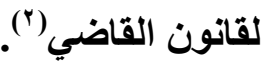

فالقانون الجنائي الأجنبي يطبق إما تحت تحفظ تطبيق القانون الأصلح للمتهم أو يطبق القانون الجنائي الأجنبي كاملا ـ سواء كان أصلح أو أسوأ استنادا لقواعد الإسناد والإحالـة ـــصرف النظر عـن قيمـة العقوبـة أو التكيـفـ القـانوني للواقعـة أو مـــي خطورتها أو يصرف النظر عنـه كليـة أو اسـتنادا للمـصالح المشتركة يطبق القـانون الجنائي الأجنبي مع مراعاة الخطة التشريعية الوطنية أو إنزال القانون الأجنبي موضع التطبيق شرط عدم التعارض مع النظام العام لقانون دولة القاضي.

(1) VAN BEMMELEN, J.M. : L'application de la loi etrangere par le juge national, Rapp. General definitif au VIIIe C.I.D.P. in R.I.D.P. 1960, PP. 7 r et. ss.

(2) GRAVEN, P. : L'appliction de la loi penal etrangere par le juge national, Actes du VIIIe C. I.D.P., Paris, 1965, p. 616 et.ss. 
ويقابـل القاضـي الـوطني أثنـاء تطبيقـه للقـانون الجنـائي الأجنبـي العديــ مـن

الصعوبات منهـا اختلاف مفهوم المصلحة الجديرة بالحمايـة الجنائية بين القـانونيين الـوطني والأجنبي لتبـاين المـصالح الثقافيـة والاقتصادية والإسـتراتيجية بـين مختلف الدول('). وكذلك وجود عقوبات جديدة لم ينص عليها مشر عه، بل أنها قد تصطدم مع النظام العام في دولته، وفي هذه الحالة فـإن القاضسي الوطني مضطر لإهمـال القانون الأجنبـي والحكم طبقاً لقانونـهـ فضلا عن اختيـار المحكمة المختصة وتفسير القـانون

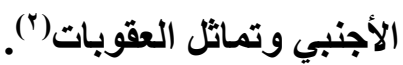

فالقاضي الوطني إما أن يقوم بتطبيق العقوبـات المنصوص عليها في القانون الجنـائي الأجنبي بنـاء على الأحكام الـواردة في الاتفاقيـات، وفي هذه الحالـة سيترك للقاضي الوطني حرية تقدير تلك العقوبات الأجنبية، وإما أن تكون هنايك جداول أو قوائم تحدد العقوبات المطابقة أو المتماثلة للتشريعات الوطنية والأجنبية على السواء، يلجأ إليها القاضي دون الخوض في الصعوبات المترتبة على تلك المشكلة(").

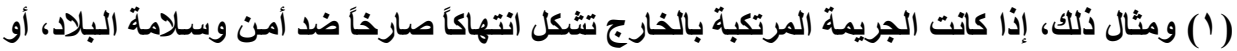

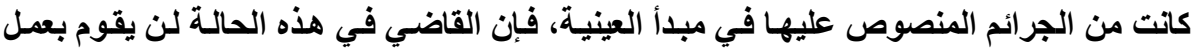

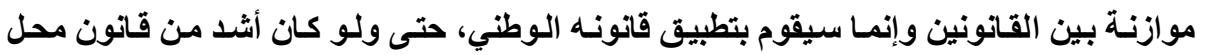

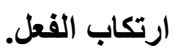

(2) DONNEDIEU DE VABRES, H. : Les principes modernes du droit penal international, Librairie du recueil sirey, Paris 1928.P.211.

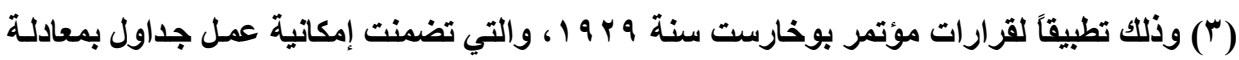

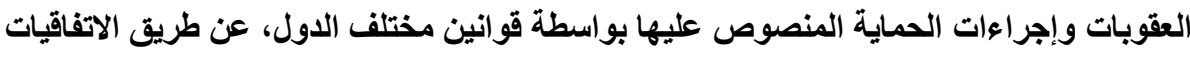


وأخيرا صعوبة عدم قدرة القاضي الوطني على المعرفة الدقيقة لقوانين الدولـة الأجنبية، وتفسير ها وإثباتها. والعيب هنـا يوجه لشخص المطبق الذي لا يكون على درايـة كاملـة بهذه القوانين. فالمشرع الوطني عندما يسن قانونـاً معيناً يفترض علم الكافة به، بل ويحاسبهم في حالة مخالفته تلك القوانين. ويمكن التظلب على ذلك عبر معاهد القانون المقـارن المعنية وفقهاء القانون أصحاب الاختصاص للوصول إلي فهم تلك القوانين وذلك بتسهيل نشاط الجمعيـات العلمية الوطنية في مواد القانون المقارن. ويمكن حلها عن طريق إرسـال طلب رسمي من الدولـة المعروض أمامهـا النزاع إلى الحكومـة الأجنبية التي وقعت على إقليمها الجريمة، يطلب فيه جميع التحقيقات اللازمة بشأن الواقعة التي ارتكبت بالخـارج، عن

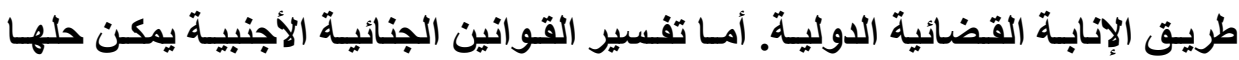
بالالتجاء إلى القواعد الخاصة بالتفسير في القوانين الجنائية الأجنبية، وفي حالة تعذر الوصول إلى التفسير المناسب للمشكلة، يمكن الرجوع في ذلك للقواعد التي يحددها المشرع الوطني.

فتطبيق القاضي الوطني للقانون الجنائي الأجنبي يشير مشكلة تنازع الاختصاص الجنائى الدولى، ولحل ذلك يترك لمحاكم الدول تحديد الاختصاص القضائي لمحاكمها، طبقاً لتقدير تشريعاتها الوطنية، ويمكن الاستعانة في تنظيم ذلك بالاتفاقيات الدولية، وتحديد هذا الاختصاص يخضع لرقابـة المحمـة العليـا في كل دولة، كمـا يمكن تحديد الاختصاص التشريعي للقـانون الواجب التطبيق، تبعـاً لأوامر مشرعها الوطني. وقد تظلبت المحكمة الجنائية الدولية علي مشكلة تنـازع الاختصاص وتنـازع السيادات في ظل القانون الدولي الجنائي الخاص. 
كما يثير تطبيق القانون الجنائي الأجنبي فكرة القوة الإلزامية لـه أمسام القضاء الوطني، وتتوقف الإجابة على ذلك على معرفة الطبيعة القانونية للقانون الأجنبي، من حيث كونه محتفظاً بوصفه كذلك، أم يفقدها ويتحول إلى مجرد واقعة. والواقع أن هذه المسألة تهم في المقام الأول فقه القانون الدولي الخـاص. وهذه المسألة يتنازعها وجهتا نظر: الأولي تذهب إلى أن القانون الأجنبي حين يطبقه القاضي الوطني فإنه يستحيل إلى عنصر من عناصر الواقع أمامه نظراً لتجرده من قوة الإلزام طالما قد خرج من نطاق سيادته ودخل نطاق سيادة أخري('). أمـا وجهة النظر الثانية فتذهب إلى أن القانون الأجنبي لا تتغير طبيعته حين يطبقه القاضسي الوطني بنـاء على قاعدة التنازع في القانون الدولي الخاص، ويظل محتفظاً بطبيعته القانونية(؟). ويترتب على تظليب إحدى وجهتي النظر على الأخرى نتـائج هامـة فيمـا يتعلق بالتفسير وطبيعة الخطأ المتعلق بالقانون الأجنبي وهل يكون خطأ في الواقع أم خطأ في القانون ومدي رقابة محكمة النقض على محكمة الموضوع في هذا الثأن. فبالنسبة للرأي الذي يري أن القانون الأجنبي يظل محتفظاً بوصفه كذلك أمسام القضاء الـوطني، فـأن القاضـي ملزم بتطبيقهـه مـن تلقـاء نفسه دون حاجـة إلى تمسكك

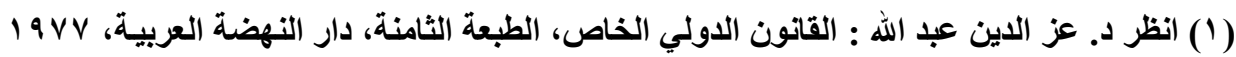

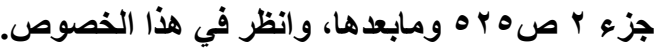

BATIFFOL : Reflexions sur in preface', in HENRI BATIFFOL - choix d'articles rassambles par ses amis" L.E.D.J. 1976, P. 137 et specialement p. 141.

(r) في تائيده وجهة النظر هذه انظر د. أحمد فتحي سرور: المرجع السابق، ص V V فقرة 1؛ 1، 
الخصوم به ـ ما لم يتعارض ذلك مع النظام العام لقانون دولة القاضي الوطني - بل أن

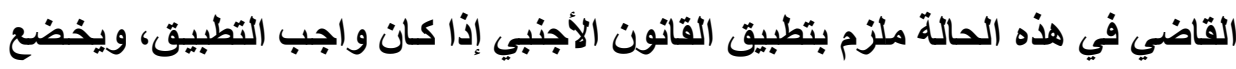
في ذلك لرقابة محكمة النقض في تفسيره وتأويله وتطبيقه. أمسا بالنسبة للرأي الذي يعتبر القانون الأجنبي مسألة "واقعة" فبإن القاضي

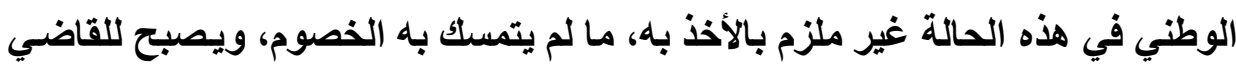

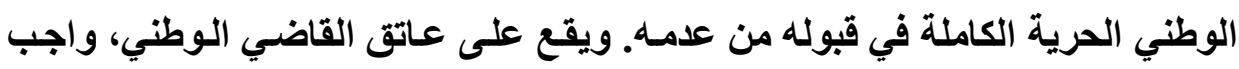

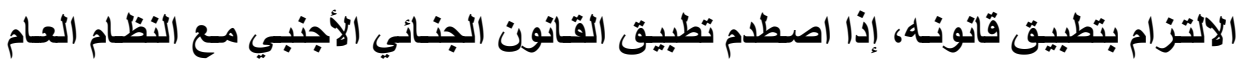
الاولي، أو كان هناك استحالة من الناحية العملية في تطبيقه أو معرفته. وحول مدي إمكانية تطبيق القانون الأجنبي أمسام محاكم الدرجة الأولي يري

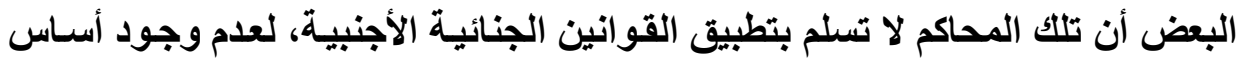
لموادها في القوانين الوطنية. كذلك فإن المحاكم ذات الدرجة الثانية أيضاً ليس بإمكانها

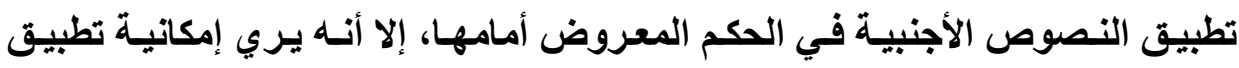
القانون الأجنبي عن طريق عمل المقارنـات بين القوانين الأجنبيـة بالنسبة للأحكام

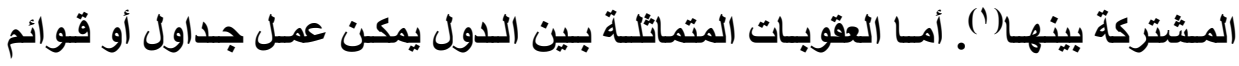
بالعقوبات المتماثلـة والمتطابقة للعديد من التشريعات الأجنبية، ليهتدي بهات التهات القاضي الوطني عند الرجوع لتلك القوانين، تفاديا لتوقيع عقوبات أثند على الجاني. وأخيراً فأنه

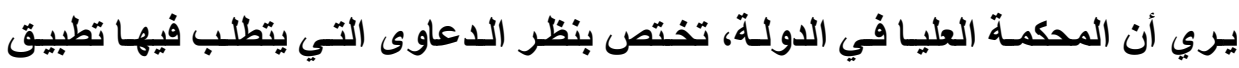

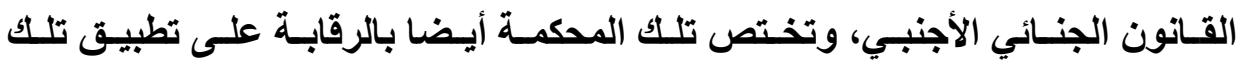

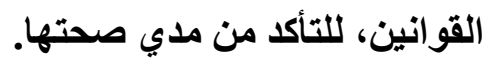

(1) GRUETZNER, H. : L'application de la loi penal etrangere par le juge national, in actes du VIIIe C.I.D.P. 1961, Lisbonnes,Paris 1965, pp. 593 et. ss 
ويؤخذ علي هذا الرأي ـ الذي يعطي المحكمة العليـا سلطة الحكم على الجنـاة الأين ارتكبوا جرائمهم بالخارج - أنه في حالة الحكم بالإدانة فإن المتهم لن يـتمكن من فن فئن استثناف حكمه، خاصة لو شـابهه عيب جوهري أو خطأ في تأويل أو تفسير القوانين

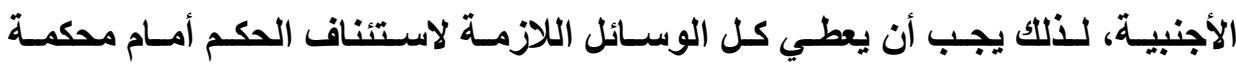


محكمة الاستئناف أو محكمة الجنايات(') فوجود محكمة مختصة بتلك الجرائم المرتكبة التهات بالخارج، يترتب عليه وجود قضاة متخصصين في ذلك النوع من الجرائم، كما أنه يمكن

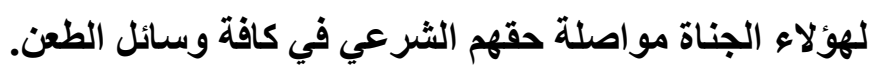
فمعظم قضاة العالم ليس لديهم الدراية الكافية بـالقوانين الأجنبية، خاصـة إذا مـا

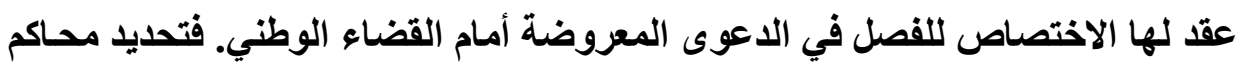
بعينها للاختصاص بهذا النوع من الجرائم، يحقق مصلحتين أساسيتين في آن واحد، أولها صدور الأحكام الوطنية على أسس سليمة يصعب نقضها فيما بعد، وثانيها إعطاء

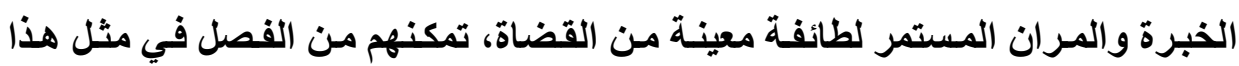

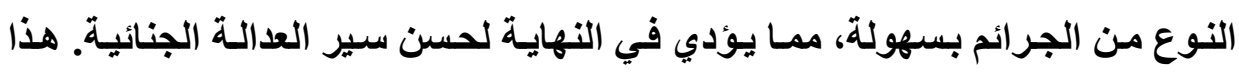

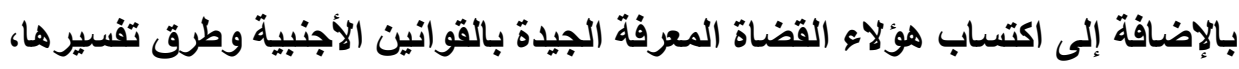
وكيفية الرجوع لأحكامها وآراء الفقه فيها. كما أن معرفتهم باللغات الأجنبية ستتيح لهم عمل نوع من المقارنات فيما بين التشريعات الأجنبية.

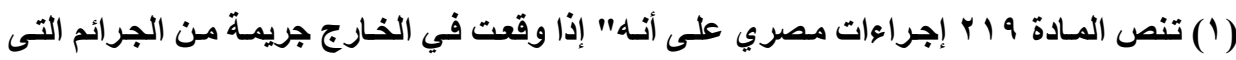

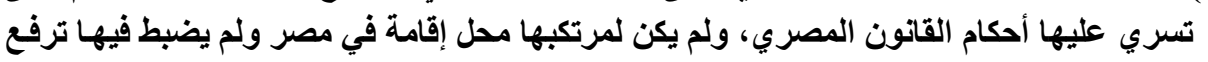

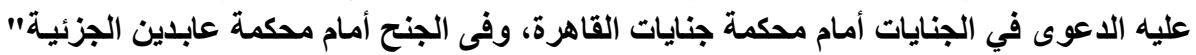

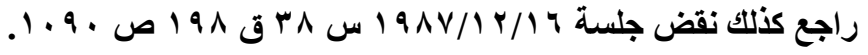


فلا يمكن بحال من الأحوال أن نلقي عبء واجب معرفة القانون الأجنبي على كل القضاة، في حالة اختصاص القانون الأجنبي بـالتطبيق، ونتيجة لذلك فإنـه يفضل إعطاء محساكم الدرجة الأولي الاختصاص بـالحكم في المخالفـات والجنح، واختصاص محكمة الاستئناف بالحكم في الجنايات. وفيما يتعلق بالتزام القاضي الوطني بالتبعية لأحكام القضاء الأجنبي، فأنه من

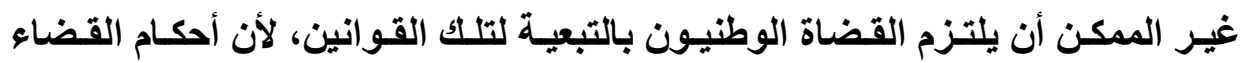
الوطني لا تخضع لأحكام القضاء الأجنبي(')، ونتيجة لذلك يترك للقاضي الوطني الحرية في الحكم، طبقاً لأحكام القضاء الأجنبي في الحالة المعروضة أمامه، وليس هناك التزام عليه بالأخذ به.

أما بالنسبة للعقوبـات المثبتة في القانون الأجنبي، فإنـه يمكن إعطاء القاضي الوطني كل السلطات لإعلان العقوبات التي يحكم بها، على أن يحقى أفضل تطبيق، طبقاً لشروط الحالـة المعروضـة أمامسه. وإزاء ذلكك يمكن تطبيق قـانون محل ارتكـاب الفعل الإجرامي، مع الوضع في الاعتبار القانون الأصلح للمتهم، ويمكن الاستعانة في ذلك باللجوء إلى جداول العقوبات المطالبة أو المماثلة بالنسبة للجرائم التي ترتكب الخارج. ويمكن تذليل الصعوبات التي تعترض تطبيق القوانين الجنائية الأجنبية عبر

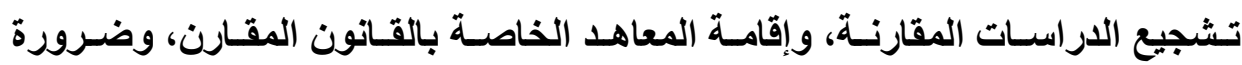
الالتجاء للمساعدة القضائية الدولية لإخبار القاضي الوطني بمضمون القانون الجنائي الأجنبي، ويقع على عاتق المحاكم العليا في البلاد، ضرورة الرقابة على التطبيق السليم للقـانون الجنـائي الأجنبي، وأخيرا ضـرورة الأخذ في الاعتبـار بـآراء الفقه، وأحكـام القضاء في الدولة الأجنبية، عند قيام القاضي الوطني بتطبيق القانون الأجنبي، خاصـة

(1) SCHWANDER, V. : Actes du VIIIe C.I.D.P. de L'A.I.D.P., Paris, 1965, pp. 599 et. ss. 
إذا ما كان النص التشريعي الأجنبي غير واضح. وعلاوة على ذلك فإنه يمكن الاستعانة

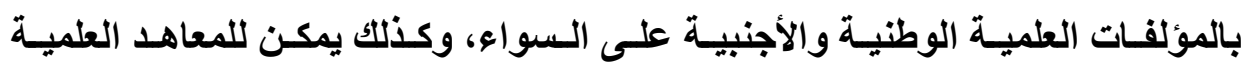
المتخصصة، أن تقوم بتقديم المساعدات اللازمة للاولة الطالبة.

كما يمكن تطبيق القوانين الجنائية الأجنبية أسوة بـالقوانين غير الجنائية عبر وضع جدول بالعقوبات المتماثلة حتى يتفادى العقبة التي تقابل القاضي الجنـائي أثنـاء تطبيقه للقانون الأجنبي، إذا ما صادفته عقوبة أجنبية غير منصوص عليها في قانونس فئه الوطني، وتلجأ العديد من الدول لوضع تلك الجداول عن طريق عقد الاتفاقيات الدولية. ويظهر هذا التقارب بين القوانين في الاشتراك، وتعدد الجرائم، والعود، ووقف التففيذ، ورد الاعتبار. وكذلك تطبيق القانون الأصلح للمتهم عبر إلزام المشرع لقاضيه الوطني بتفضيل القانون الذي يتضمن العقوبة الأخف في حال تنازع القانون الأجنبي مـع نظيره الوطني. وكذلك توحيد القانون الجنائي الدولي عبر توحيد القوانين الجنائية الداخلية دون الاعتداء على سيادة الدولة على إقليمها، طالما أن القاضي يطبق تلك القوانين الأجنبية بمقتضي نص قانوني من مشرعه الوطني، والذي يفرض على القاضسي الوطني إتباع

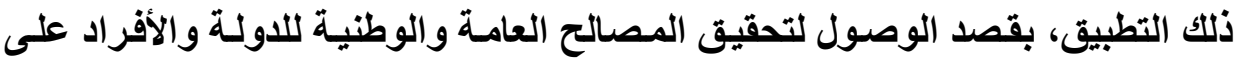
(السواء) (1) ويمكن دعوة الحكومـات إلـي تعديل مششروعات قوانينهـا الجنائيـة بمـا يحقق

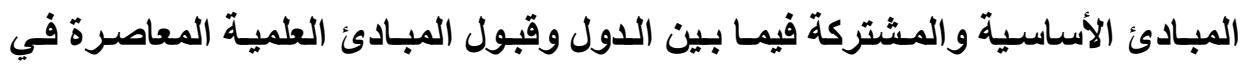
القانون الجنـائي بغيـة ردع الإجرام الدولي ويكون ذلك من خلال الاهتمـام بالاتفاقيـات

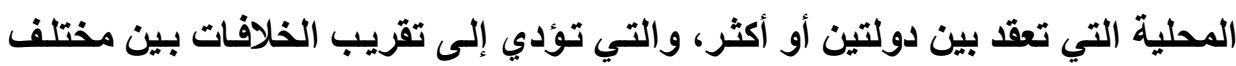

(1) DONNEDIEU DE VABRES, H. : Les principes modernes du droit pénal international, Librairie du recueil Sirey, Paris 1928.P.214. 
التشريعات الأجنبيـة، فهي تعتبر بدايـة الطريـق لعقد العديد من الاتفاقيـات التي تمتــ

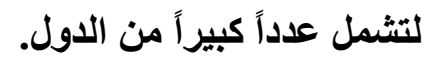

ونشير في هذا الصدد إلي التحول القضائي الفرنسى من رقابـة محكمة النقض علي الخطأ في تطبيق القانون الأجنبي إلي استبعاد تلك الرقابة من خلال رفض الطعون

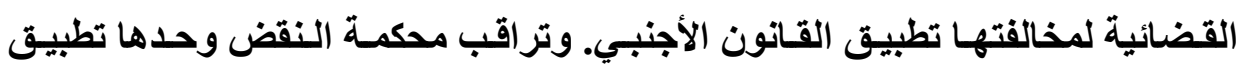
القوانين الأجنبية، وتفرض محكمة النقض رقابتها هذه على مخالفة القانون(') والخطأ

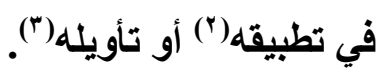

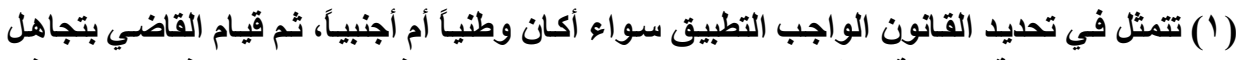

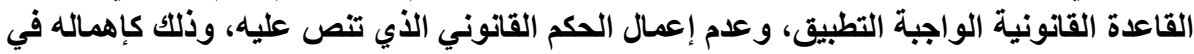

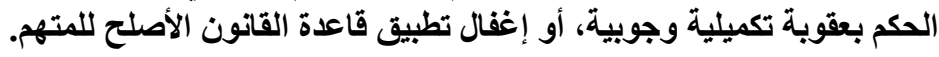

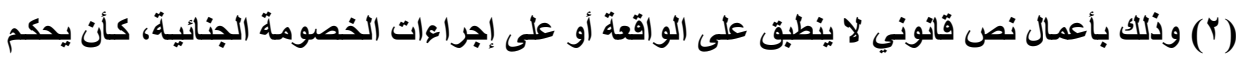

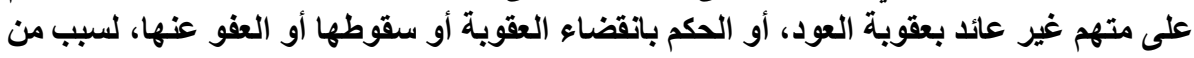



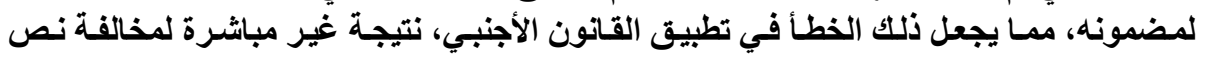

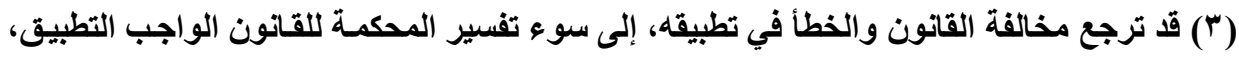

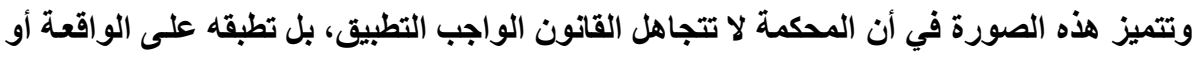

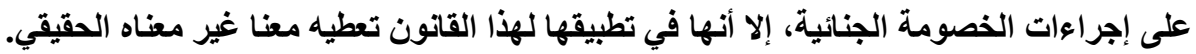

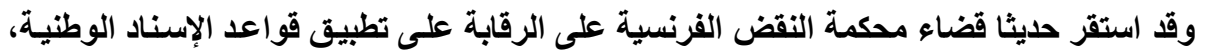

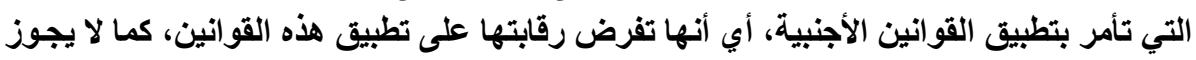

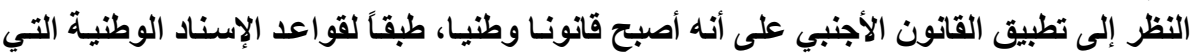
أشارت بتطبيقه، حيث يظل القانون الأجنبي محتفظاً بصفته وطبيعته هذه أمام القضاء التهاء الوطني. 


\section{المبحث الثاني}

الأخذ في الاعتبار الأحكام الجنائية الأجنبية

سوف نعرض في هذا المبحث لمدي الأخذ في الاعتبار الأحكام الجنائية الأجنبية في مطلب أول، ثم نعرض للآثار المترتبة على ذلك في مطلب ثان.

\section{المطلب الأول}

\section{هدي الأخذ في الاعتبار الأحكام الجنائية الأجنبية}

يقصد بالأخذ في الاعتبار عدم اعتراف الدول بالقوة التنفيذية للحكم الجنائي

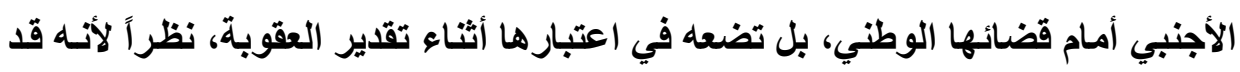

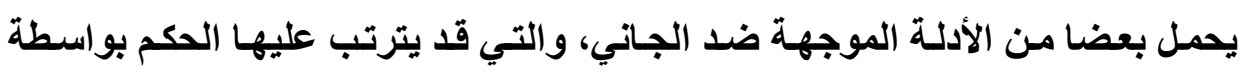
القاضي الجنائي الوطني. فالحكم الجنائي الأجنبي الذي صدر بالخارج قد يحوز من القوة والآثار أمام القاضي الوطني أكثر مما يحوزه بمكان صدوره، أو أنع تمكن من الهرب الهي بعد صدوره، ممـا يجعل أمر تنفيذه مستحيلاً. بعكس مـا إذا وجد المحكوم عليه أمسام قاضيه الوطني، الذي يقوم بإعادة تحقيق الوقائع من جديد، وفحصها بكل دقة ومواجهة بعائ

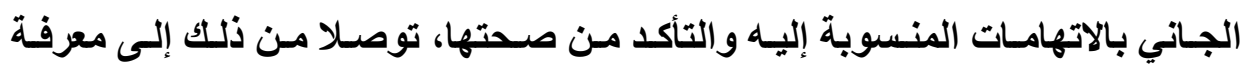


الحقيقة لإصدار حكم جنائي عادل، سواء أكان مؤيداً للحكم السابق صدوره بالخـارج أم

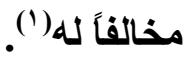
وأمسام الآثار السيئة الناجمة عن زيـادة معدل الجرائم العابرة للحدود وقواعد العدالة التي تأبي إعادة محاكمة المجرم من جليد لنفس الواقعة وجب وجود نوع من الارتبـاط بين الحكم الجنـائي الصادر بالخـارج، وقانون البلـد الذي لجـأ إليهـ المجرم، لوضعه في الاعتبـار عنــ الحكم عليـه مـن جديد، طالمـاً أصبح أمـر تنفيذ هذا الحكم مستحيلاً عبر تحديـ طبيعة هذا الحكم وكيفيـة إصـاره بالخـارج، لمحاولـة الوصـول للعدالة التامة، سواء بالنسبة للجاني أو بالنسبة للمجتمع. ونخلص مـن ذلكك إلـي أن القاضـي الجنـائي يمكنهـه المفاضـلة بين تنفيذ الحكم الجنائي الأجنبي، أو على الأقل أخذه في الاعتبار إذا مـا وجد صعوبة كبيرة في تنفيذه من حيث شدة العقوبة أو تخفيفها، على أن يكون ذلك الأمر منصوص عليه في قانون القاضي الوطني.

وإذا كان العرف الدولي يقرر عدم قوة الأحكام الجنائية خارج حدود الدولـة التي أصدرتها، على عكس الأحكام المدنية والتجارية التي تمتد آثارهـا التنفيذيـة خـارج إقليم صدورها. فلا يعتد بهذه الأحكام الجنائية كسابقة في العود، أو في شـأن تعدد العقوبـات، ولا تؤدي إلى أثثار جنائية أو عقوبات تبعية في الاخل، مثل الحرمان من بعض الحقوق

(1) ROPERS, J. L. : Le marche commun et les effets internationaux des jugements repressifs, J.C.P. 1963. I. 1797. 
أو المزايا، حتى ولو كان مثلها مقرراً في التشريع الأجنبي الذي صدرت الأحكام تطبيقاً

كذلك لا أثر للحكم الجنائي الأجنبي في الدعوى المدنية التي قد يقيمها المضرور

مـن الجريمـة للمطالبـة بـالتعويض في مـصر، إلا على سـبيل الاسـتـلال. فهو لا يقيــ القاضي المدني فيما قد ينتهي إليه من ثبوت الواقعة، أو وصفها القـانوني أو إسنادها إلى الجاني، بعكس الحكم الجنائي الوطني الذي يقيد القاضي المدني في كل هذه الأمور

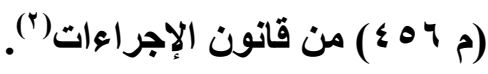
الأثر الساببي للمكم الجنائي الأجنبي : يتمثل هذا الأثر فيما يتمتع به من قوة الأمر المقضي أمسام القضاء الوطني. وقد أخذ المشرع المصري بهذا الأثر بالنسبة للجرائم التي تقع بالخـارج، بشرط ضرورة تنفيذه، واستيفاء العقوبة كاملة دون نقص، وإلا فسوف تعاد المحاكمة من جديـ عن ذات الفعل (م \& ) من قانون العقوبات. وبناء على ذلك فإن البعض يري أن تلك العقوبـة الصادرة بالخـارج إذا سقطت بالتقادم أو العفو الثـامل، فلا يمنع ذلك من إعادة المحاكمة من جديد، بحجة أن الهـف الذي من أجله وضعت المادة الرابعة، هو عدم إفلات الجاني من العقاب، وطالما لم ينفذ عقوبته جزاء ما اقترفت يداه، فلا مانع من إعادة المحاكمة من جديل، بغض النظر عما هـ إذا كانت أسباب عدم التفيذ ترجع لسقوط الحق بالتقادم أو للعفو الشامل ، أو لصدور

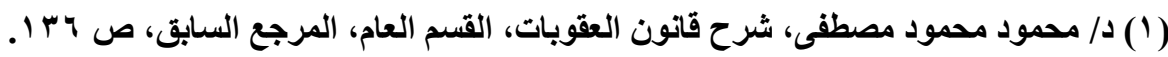

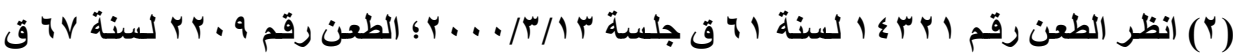

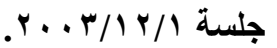


قرار بحفظ الـعوى، أو لعدم وجود وجـه لإقامتهـا مهــا كانت الأسباب، وكذا جميع الأحكام الصادرة قبل الفصل في الموضوع كعدم القبول أو عدم الاختصاص('). وعلى عكس الاتجاه السابق يري البعض أن الاستيفاء الكامل للعقوبـة يتم في ضوع نصوص القانون الأجنبي، نظراً لأن تقـادم العقوبـة أو العفو عنهـا هو في حكم تنفيذها قانوناً، والقياس جائزاً إذا ما كان في صالح المتهم، حتى ولو كان الحكم الجنائي الأجنبي صـادراً بالعقوبـة مـع وقف التنفيذ، حيث أن وقف تنفيذ العقوبـة هو نوع من المعاملة العقابية لصنف معين من المجرمين قد لا يتلاعم حالهم مـع إيداعهم بالسجن، فهو وصف مكمل للعقوبة المحكوم بها، ويظل المتهم مهدداً بتنفيذها خلال فترة معينة إذا ثبت سوء سلوكه على نحو معين، مـع الوضـع في الاعتبـار أن مضي فترة وقف التنفيذ دون إلغاء الحكم، سوف يؤدي إلى اعتبار حكم الإدانة كأن لم يكن، مما يجب معه قياسه على حكم البراءة، وهو قياس جائز طالما كان في مجال الإباحة أو التخفيف(). بينما يمكن التفرقة بين تقادم الجريمـة وتقـادم العقوبـة، حيث أن تقـادم الجريمـة أو العفو الشامل إذا تم وفقاً للقانون الأجنبي، فأنه يجعل الفعل غير معاقب عليه، الأمر الأي يؤدي إلى عدم إمكان محاكمة المصري الذي يعود بعد ذلك إلى مصر، أمسا تقادم العقوبة أو العفو عنها فلا يحول دون إعادة المحاكمة من جديد. ونخلص ممـا سـبق أنسه تحقيقـا لصسن سبير العدالـة لا يجب أن نلتزم بحرفيـة النصوص وجمودها للحد الذي يفقدها معناها وقوتها، والغرض الذي من أجله شرعت، فالمادة الرابعة تهدف إلى عدم هروب الجنـاة من إنزال العقاب بهم جزاء مـا اقترفته 
أيديهم، فطالما ضبط المتهم وقدم للمحاكمة بالخارج وصدر ضده حكم بـات في الدعوى الجنائية طبقاً لأحكام القانون الجنائي الأجنبي، ورأي القاضي المعروض أمامه الدعوى

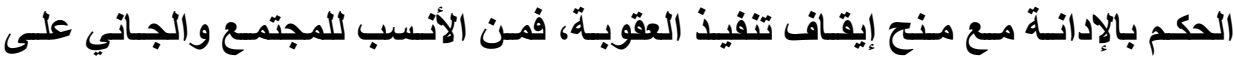
السواو، أن يظل الأخير مهلداً بتوقيع العقوبـة عليه فترة معينـة دون تنفيذها، حيث قـ يخلق هذا التنفيذ منه مجرماً آخرا أشد خطورة. ولعل اعتراف المشرع المصري بالأثر السلبي لهذه الأحكام يقضي على الحجـة التـي تطالب باسـتبعادها لتعارضـها مـع سـيادة الدولـة، ولعـدم الثقـة فـي التشريعات الأجنبية، خاصة أو المناهضين لفكرة عدم الأخذ بالأحكام الجنائية الأجنبية، يعترفون بإمكانيـة الوضـع في الاعتبـار العقوبـة التي قضاها المتهم بالخـارج، في حالـة صدور عقوبة جديدة عليه.

\section{الأثر الإيجابي للمكم الجناني الأجنبي :}

يتمثل في قوتهه التنفيذيـة خـارج حدود الدولـة التي أصدرته، فقد رتب القـانون المصري أثرا إيجابياً للحكم الجنائي الأجنبي، فيما يتعلق بأثره في منـع إدارة مدرسـة أو الاشتغال بالتدريس أو بأي عمل آخر من أعمال التعليم أو الضبط أو الإدارة. كما أن المادة الثالثة عشرة من مشروع قانون العقوبات تنص على أنها "يجوز الاستنـاد إلى الأحكام الجنائية الباتـة الصادرة من المحاكم الأجنبية العاديـة في جرائم منصوص عليها في هذا القـانون وقعت في الخـارج وذلتك لتنفيـذ العقوبـات الفرعيـة والتدابير، متى كاتت متفقة مع أحكام هذا القانون، ولإجراء الرد والتعويض وغير ذلتك من الآثار المدنيـة. أو لتوقيع العقوبـات الفرعيـة والتـابير المنصوص عليها في هذا 
القانون أو الحكم بـالرد والتعويض. أو لتطبيق أحكام هذا القانون فيمـا يختص بـالعود

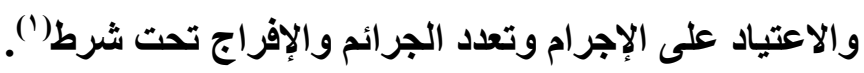

ويجب للاستناد إلى حكم أجنبي، التببت مـن صحته واعتمساده أمسام المحكمة

المطلوب التنفيذ في دائرتها، والمختصة بنوع الجريمـة المقضي فيها، ومـع ذلك إذا رفعت الدعوى واستتد فيها إلى الحكم الأجنبي، فيكون اعتمـاده من اختصاص المحكمة التي تنظر أمامها الدعوى.

وإذا كان تنفيذ الأحكام الجنائية الأجنبية لا يتنافى مع فكرة السيادة إلا أنها يجب

على الدول أن تتعاون للتظلب على الصعوبات العملية التي تواجه هذا التنفيذ. فيجب للاعتراف بالأحكام الجنائية الأجنبية ضرورة توافر بعض الثروط السابقة على التفيذ وهي أن يكون الحكم الجنائي الأجنبي حسائزاً لقوة الشيء المقضي فيه. ويشترط أن يكون الحكم حضورياً، حيث تستبعد من مجال التنفيذ بصفة عامـة الأحكام الغيابية، إلا إذا كاتت صادرة عن جريمة من الجرائم البسيطة أو كان فاعل الجريمـة قد قدم دفاعه. وأن يكون الفعل الذي صدر بسببه الحكم مجرماً في دولـة صدوره، ودولـة التنفيذ على السواء، (ازدواج التجريم). وألا يكون الحكم الجنائي الأجنبي صـادراً عن جريمـة من الجرائم السياسية أو المرتبطة بها أو العسكرية أو المالية وأن تكون الإجراءات التي اتبعت في إصدار الحكم الجنـائي الأجنبي موافقة للمبادئ الأساسية التي نصت عليها إعلانات حقوق الإنسان والاتفاقيات الدولية. وألا يكون الحكم الجنائي الأجنبي مخالفًاً

(1) GARRAUE, R. : Traite theorique et pratique du droit penal francais, T.I, $3^{\mathrm{e}}$ ed, Librairie du recueil sirey, Paris, 1913.

$$
\text { راجع: د/ أحمد فتحي سرور، المرجع السابق، ص ؟ ؟؟. }
$$


للنظـام العـام فـي الدولـة المنفـذة، بمعنى ألا يترتب على تنفيذه المساس بالمـصالح

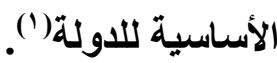

ويترتب علي الاعتراف بـالأثر السلبي للحكم الجنائي الأجنبي أن يكون للحكم

الجنائي الأجنبي قوة الشيء المقضي بـه في جميع الحسات التي يكون للاولـة فيها اختصاص تبعي، بشرط ألا يكون ذلك متعارضاً مع قاعدة عدم جواز المحاكمة عن الفعل الواحد مرتين. كما يجب أن تخصم مدة العقوبة التي قضاها المحكوم عليه بالخـارج عن نفس الجريمة، عند تنفيذ الحكم الجنائي في الدولة الأخرى. ولا يجوز الاعتراف بـالحكم الجنائي الأجنبي إلا إذا كان المحكوم عليه قد نفذ عقوبته أو صدر عفو عنها أو سقطت بالتقادم. وأخيرا إذا بأت إجراعات المحاكمة في دولة مـا من أجل جريمـة مرتكبة على الهى إقليمها، فإن السلطات القضائية في الدول الأخرى تمتنع عن القيام بـإجراء المحاكمـة

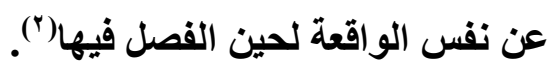
أما الآثار الإيجابية للاعتر اف بالأثر الإيجابي للحكم الجنـائي الأجنبي تتمثل في عدم إمكانية مواجهة تنفيذ الأحكام بغير قيد عبر عقد اتفاقيات بين الدول بشأن تنفيذ هذه الأحكام في جرائم معينة، وذلك حتى يكون الاعتراف بالحكم الجنائي متبادلا. كما أن الدولة التي يقيم عليها المحكوم عليه لها حريـة الاختيـار في أن تقوم بتسليمه للاولة

(1) BOUZAT, P. : Les effets international des jugements repressifs, in cours de l'institut des hautes etudes internationales des l'universite de paris, $1968-1969,2^{\mathrm{e}}$ partie, pp. $1 \leqslant$ et. ss.

(2) BOUZAT, P. : Les effets international des jugements repressifs, in cours de l'institut des hautes etudes internationales des l'universite de paris, $1968-1969,2^{\mathrm{e}}$ partie, pp. $1 \leq$ et. ss. 
التي أصدرث الحكم لتنفيذه العقوبة بمعرفتها، أو تقوم هي بتنفيذها عليه. وفضلا عن ذلكك لا يجوز تنفيذ الحكم الجنائي الأجنبي إذا كانت العقوبـة قد سقطت بالتقادم، طبقاً لقـانون الدولة التي أصلدته أو الدولة المطلوب منها التنفيذ. وكنلك الحسال إذا حصل فاعل الجريمة على عفو عن العقوبة أو عن الجريمة ذاتها في أي من الدولتين('). كما يمكن استبدال العقوبة المحكوم بها بعقوبة أخرى منصوص عليها في قانون الدولة المنفذة لنفس الجريمة، على ألا يكون في ذلك تثديد على المحكوم عليه. وفيمـا يتعلق الأحكام الجنائية الأجنبية الصادرة بمراقبة الأثخاص المحكوم عليهم أو المفرج عنهم تحت شرط، يجب أن يكون تنفيذها ممكناً في أي دولة أخرى كدولة محل الإقامـة. وفي حالـة مخالفـة المحكوم عليـه للشروط المفروضـة، يمكن أن يـصدر حكم جديـــ موضوعي من قضاء الدولة التي أصدرت الحكم السابق، أو من الدولة التي يجري فيها التنفيذ. ويفضل القضاء الأخير تبسيطاً للإجراءات، على أن ينفذ هذا الحكم ـ كقاعدة عامة ـ عن طريق دولة الإقامة، وإذا استحال تنفيذه فيسلم المحكوم عليه لاولة إصدار الحكم الأصلي، لتنفيذ العقوبة عليه. وفيمـا يتعلـق بالعقوبـات التبعيـة للأحكـام الجنائيـة الأجنبيـة، كسقوط الحقـوق والحرمان من ممارستها كحظر مزاولـة مهنة معينة يمكن تنفيذها في أي دولة أخرى متى كانت معروفة في نظامها القانوني، ويمكن إصدار حكم جديد بتنفيذ العقوبة التبعية، بناء على الحكم الجنائي الأجنبي الصادر بالعقوبة الأصلية الذي يحدد الواقعة وإسنادها

(1) BOUZAT, P. : Les effets international des jugements repressifs, in cours de l'institut des hautes etudes internationales des l'universite de paris, $1968-1969,2^{\mathrm{e}}$ partie, pp. $1 \leq \checkmark$ et. ss. 
وتكييفها القانوني. ويمكن الاسترشاد في ذلك بصحيفة سوابق المحكوم عليه، بناء على الاتفاقيات الدولية المبرمة في هذا الثأن.

فالوضع في الاعتبار الأحكام الجنائية الأجنبية يعين القاضسي في التعرف على الثخصية الإجرامية للمذنب من خـلال إطلاعه على صحيفة سوابقه، والتي لا تعتمد على الصفة الوطنية أو الأجنبية للمحكوم عليه. فقد تكون السوابق القضائية الوطنية أقل بكثير من السوابق القضائية الصادرة بالخارج. مما لا شك فيه أن تقييم المجرم من جمع الوجوه ودراسـة شخصيته، سواء على المستوي الوطني أو الأجنبي، قد يعطي للقاضي صورة واضحة عن أبعاد هذا الجـاني، ليتمكن من إصدار حكم عـادل ودقيق، يحقى فيه مصلحة المجتمع من ناحية ومصحة الجاني من ناحية أخرى. كما يجب مراعاة تثابه الأحكام الجنائية الأجنبية بالأحكام الوطنية بقر الإمكان، فيما يتعلق بتطبيق أحكام العود، وتعدد الجرائم، والإفراج الشرطي، وغيرهـا من النظم القانونيـة التي تعرفها كل من الدولتين. ويجب على القاضسي الوطني عند الحكم في الاعوى، أن يضع في اعتباره ضرورة مساواة الأحكام الجنائية الأجنبية بتلك الصادرة باللداخل، خاصـة فيمـا يتعلق بالعقوبـات الأجنبيـة الصادرة برد الاعتبـار، أو العفو عن

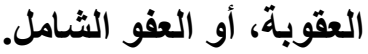
أمـا عن الإجراعات الخاصـة بـالاعتراف بالأحكـام الجنائيـة الأجنبيـة فيترك لكل

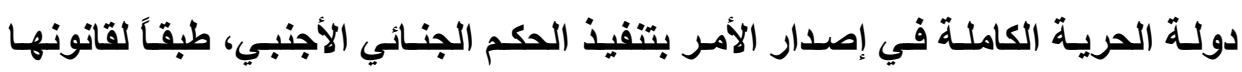
الـوطني، بعد التأكد مـن صـحة الحكم مـن الناحيـة الإجرائيـة، دون إعـادة النظر في موضوع الدعوى من جديد. ويتم الاعتر اف بـالحكم الجنائي الأجنبي عن طريق دعوى تنفيذية أمام القضاء الوطني، أو بأي وسيلة أخرى استنادا إلي الثقة المطلقة في قضاء 
الاولة الأجنبية. وأخيراً يتم ذلك الاعتر اف بالأحكام الجنائية الأجنبية عن طريق عقد الاتفاقيات الدولية الثنائية منها والجماعية، في إطار التضامن الدولي لتحقيق العدالة


وفي هذا السياق يمكن إبراز أهم السمات الأساسية المتعلقة بتنفيذ هذه الأحكام من خلال وضع قواعد معينة لكي يحوز الحكم الجنائي الأجنبي قوة التنفيذ على الإقليم الوطني، ووضع ضمانات للمحكوم عليه لتقديم دفاعه أمسام القضاء الوطني قبل تتفيذ الحكم الجنائي الأجنبي عليه، ووضـع الأسباب التي من أجلها يمكن رفض تنفيذ هذه الأحكام، مـع استبعاد بعض الجرائم من نطاق تنفيذ هذه الأحكام كـالجرائم السياسية والعكرية البحته والمالية. فضلا عن تحديد الإجراعات التي يجب أن تنتهجها الدولة الطالبـة لتنفيـ الحكم الجنـائي الأجنبي، لكي يجوز طلبهـا القبول في الدولـة المنفذة.

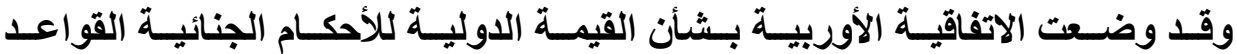
الخاصـة التـي بمقتضاها تعد العقوبـة مطابقة لقوانين الدولـة المطلوب منهـا التنفيذ، فخصمت العقوبـة التي قضاها المحكوم عليه بالخـارج من نفس الجريمـة، عند تنفيذ الحكم الجنائي الأجنبي عليه عبر احترام مبدأ عدم جواز محاكمـة الشخص مرتين عن

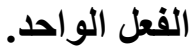

(1) BOUZAT, P. : Les effets international des jugements repressifs, in cours de l'institut des hautes etudes internationales des l'universite de paris, $1968-1969,2^{\mathrm{e}}$ partie, pp. $1 \leqslant \wedge$ et. ss. 


\title{
المطاب الثانى
}

\section{آثار الأحكام الجنائية الأجنبية}

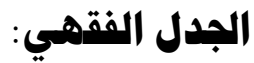

يترتب علي الأحكام الصادرة في المسائل الجنائية من محكمة دولية أجنبية قيمة

دولية بعضها في صالح المتهم ويقصد بها الآثار السلبية للحكم الأجنبي والتي تتجسد قيمته في الحيلولة دون إعادة محاكمة الجاني من جديد أو في التأثير على مقدار الجزاء الأي يحكم به على الجاني عند إعادة محاكمته في مصر. فيعتبر الحكم الجنائي الأجنبي سبباً لانقضاء اللدعوى الجنائية، بحيث لا يجوز محاكمة المتهم عن ذات الواقعة مرة أخرى، تطبيقًا لقاعدة عدم جواز محاكمة المتهم عن فعل واحد مرتين وهي قاعدة من قواعد العدالـة التي لا يمكن إغفالها أو إنكارهـا. وبعضها الآخر ضـد مصلحة المتهم ويقصد بها الآثار الإيجابية للحكم الأجنبي والتى تبدو متمثلة في القوة التنفيذية لهذا العكم خارج البلا الأي صدر فيه، وأثره في توافر حالة العود إلى الجريمـة إذا مـا حوكم الجاني عن جريمة أخرى أمام المحاكم الوطنية.
\end{abstract}

فقد أثثارت قيمـة الأحكام الجنائية الأجنبيـة جدلاً فقهيـا أدي إلى ظهور نظريتين أحدا هما تنكر هذه القيمة والأخرى تعترف بهـا(') فـإذا كـان احترام الحكـم الأجنبـي

(1) Barbey: De l'appliation internationale de la regle. Non bis in idem, these, Lausanne, 1930, p. 135. Travers : Les effets internationaux des jugements repressifs. Recuell des cours de l'Academie de droit international 1924, p. 460. Double jepady compared with Non Bis Inidem.

$=$

مجلت البحوث القانونيت والإقتصاديت . . 1 
يتعارض مع مبدأ سيادة الدول إلا أن هذا الأثر لا يترتب إلا باختيار الاولة وموافقتها توطئة لضمان فاعلية الالتزام الملقي علي عاتقها بحمايـة الأمن والسلم في كل مكان، ومن ثم لا يتقيد توقيع الجزاء الجنائي بنطاق إقليم الدولة. وهو مـا يفند حجة أن كل دولة تستأثر وحدها بتقدير الإجراعات اللازمة لاستتباب الأمن في إقليمها، وإقرار قوة الأمر المقضي للحكم الجنائي أو تنفيذه سوف يحل القانون الأجنبي محل القانون الوطني في تحديد الإجراء اللازم لمواجهة الإخلال بالأمن العام في الدولة. وإذا كانت النيابة العامة تختلف من دولة إلى أخرى، إلا أن وحدة المجني عليه (المجتمع) والمصلحة محل الحمايـة (القيم الأخلاقية ) يحقق شرطوحدة الخصوم في الحكم الجنائي الأجنبي والدعوى الجنائية المرفوعة أمام المحاكم الوطنية. فالأثر السلبي للحكم الجنائي الأجنبي يتمثل فيما يتمتع به من قوة الأمر المقضي أمسام القضاء الـوطني فقد سـحت بعض التشريعات بخصم مدة العقوبـة التي ينفذها الجـاني طبقاً للحكم الأجنبي (') والأصل أن الحكم الأجنبي لا يحوز أدنـي قوة بالنسبة للجرائم التي تقع داخل إقليم الدولة. إلا أن بعض التشريعات خرجت عن هذا الأصل العام

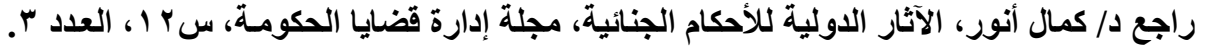

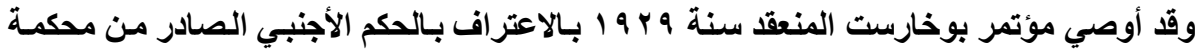

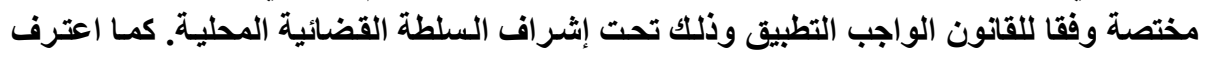

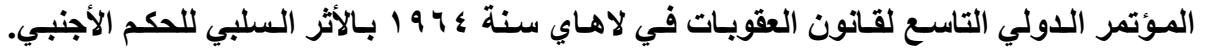

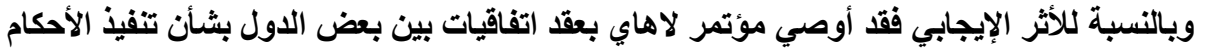

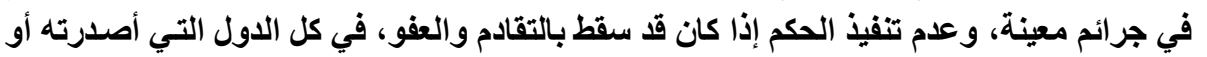
التي يراد تنفيذه فيها.

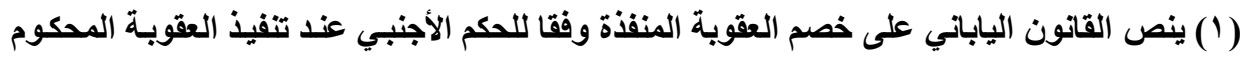

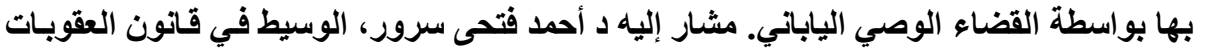

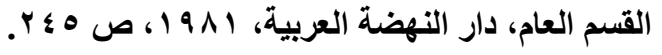


واعترفت بقيمة الحكم الأجنبي ولو كـان صـادراً في جريمـة وقعت داخل إقليم الدولة. مثال ذلك القانون الهولندي والإنجليزي. وقد اعترف القانون الفرنسي بـالحكم الأجنبي عن أفعال الاشتراك التي تقع في فرنسا إذا كانت الجريمـة محل الاشتثراك قد وقعت في

$$
\text { الخارج (المادة ب } 99 \text { إجراعات) (') . }
$$

وفى هذا نوصي المشرع بتدارك العيب التشريعى الخـاص بقصور الأثر السلبي

للحكم الأجنبي على الجرائم المرتكبة في الخـارج والتى تـخل في اختصاص قـانون العقوبـات طبقـا لمبـدأ الشخصية الايجابيـة دون شـمول ذلـــ الجـرائم التـي تـدخل في اختصاص قانون العقوبات طبقاً لمبدأ العينية.

ونتوه إلسى أن التشريعات التـي تعترف بـالأثر السلبي للحكم الجنـائي الأجنبي

تشترط أن يحوز الحكم قوة الأمر المقضي(؟)، وأن يتم تنفيذه. وقد اعترف القـانون المصري بالأثر السلبي للحكم الجنائي الأجنبي (المادة ؛) بالنسبة إلى الجرائم التي تقع

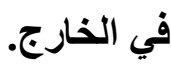

(1) Article 692 :Dans les cas prévus au chapitre précédent, aucune poursuite ne peut être exercée contre une personne justifiant qu'elle a été jugée définitivement à l'étranger pour les mêmes faits et, en cas de condamnation, que la peine a été subie ou prescrite. Modifié par Loi n99-515 du 23 juin 1999 - art. 30 JORF 24 juin 1999.

وقد ثار البحث عن مدي صلاحية الحكم الأجنبي الصادر بالإدانة كسابقة في العود. و أنكرت محكمـة

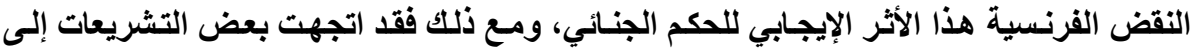

$$
\text { الاعتداد بهذا الأثر في حدود معينة. راجع في ذلك: الأني }
$$

Crim. 7 nov. 1968. D. 1969-220.\& Rev. Inter, de droit penal 1963, p. 108.

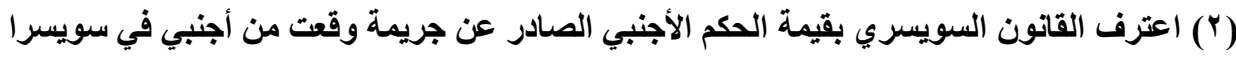
إذا كاتت محاكمته في الخارج قد تمت بناء على طلب السلطات السويسرية (المادة ب/ باع عقوبات). 
أما عن الأثر الإيجابي للحكم الأجنبي يتمثل في قوته التنفيذية خارج الدولة التي صدر منها. وقد اعترفت بعض التشريعات بهذا الأثر مثل الاتفـق المصري السوداني المنعقد سنة r ـ 19 والذي ينص على أن حكومة السودان تتفذ بناء على طلب الحكومة المصرية الأحكام الصادرة من المحاكم المصرية بالحبس الذي يقل عن ستة شهور، فإذا زادت مـدة الحبس المحكوم بهـا عن ذلكك يكون للحكومـة المسرية أن تطلب تسليم

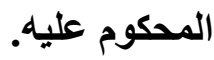
وبمقتضي الفقرة الثانية من المادة الرابعة من قانون العقوبات "لا تقام الدعوى العموميـة على مرتكب جريمـة أو فعل في الخـارج إلا مـن النيابـة العموميـة ولا يجوز إقامتهـا على من يثبت أن المحاكم الأجنبية برأتهـ ممـا أسنـا إليه أو أنها حكمت عليه نهائياً واستوفي عقوبته". يكون المشرع المصري قد رفض الاعتراف للحكم الصادر من القضاء الأجنبي بأيـة قوة تثفيذيـة أصلية أو ثانويـة(')، أو بقوة الشيء المحكوم فيه(') لكنه مع ذلك جعل لهذا الحكم أثرا محددا هو منع إقامـة الدعوى ثانيـة إذا كـان المتهم قد حوكم في الخارج وقضي ببراعته أو بإدانته واستوفي العقوبة. وتوجد إلى جانب الأثر الإيجـابي للحكم الجنـائي الأجنبـي المترتب عن القوة

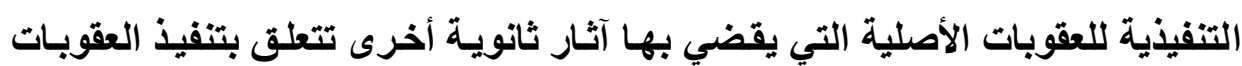

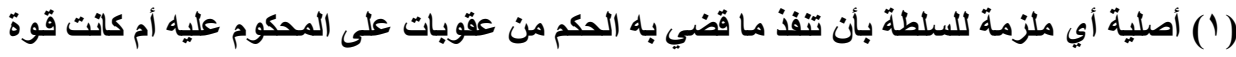

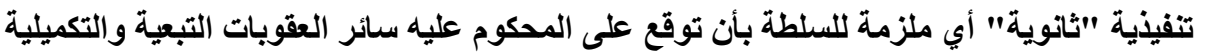

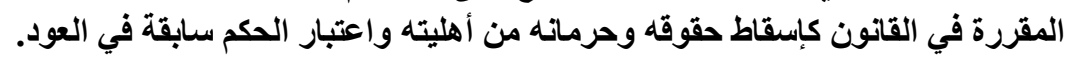

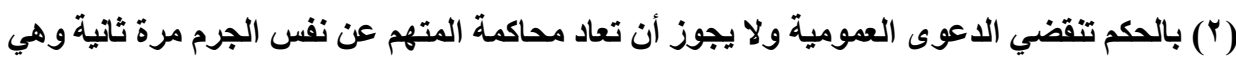

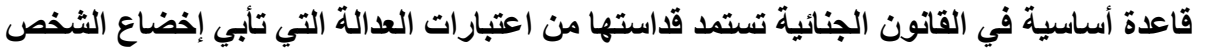
مرتين لعذاب الاتهام وإجباره مرتين على تبديد الثبهات التي تلور حولئ. 
التبعية والتكميلية. فإذا كان الاتجاه السائد في التشريعات الجنائية هو عدم الاعتداد بهذه العقوبات استناداً إلى ما في ذلك من مساس بسيادة الدولة على إقليمها. إلا أن الاعتراف للحكـم الجنـائي الأجنبـي بهـذه الآثـار القانونيـة ضـرورة توجبهـا حمايـة الدولـة مـن الأشخاص الخطرين عليها. إذ من غير المقبول أن يعترف للشخص خارج دولته بحقوق ومزايا لا يتمتع بها في إقليم دولته بسبب صدور أحكام أدانه ضده.

أما الوضع في قانون العقوبات المصري يتمثل في عدم اعترافه للحكم الأجنبي بقوة تنفيذية بالنسبة للعقوبات الأصلية التي يقضي بها، ولكن قد يكون هذا الاعتراف بناء على معاهدات دولية(')، ولا يعترف القانون الحالي للحكم الأجنبي بقوة تنفيذيـة بالنسبة لآثاره الثانوية، ولكنه قد يعترف بذلك بنـاء على نصوص خاصـة وفي حالات محددة(؟): ويعترف القانون الحالي للحكم الأجنبي بقوة الشيء المحكوم فيه بشروط معينة تنص عليها المادة الرابعة من قانون العقوبات. مثال ذلك القانون رقم ب^ه لسنة هـ 19 في شأن تنظيم المدارس الحرة. إذ تقضي المادة الرابعة منه بمنع المحكوم عليه من محكمة أجنبية لجنايـة أو جنحة ماسـة بـالأخلاق أو بالشرف أو بالأمانـة مـن امتلاك مدرسة حرة، كما يمتنع عليه بموجب المادة السابعة من هذا القانون أن يدير مدرسة أو يعمل فيها بـأي عمل من أعمـال التدريس أو التعليم أو الإشراف أو الضبط أو الإدارة، فالقانون يسوى في هذا الثأن بين الحكم الجنائي الأجنبي والحكم الجنائي الصادر من المحاكم المصرية.

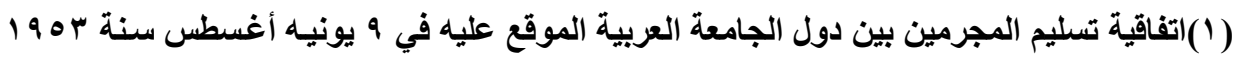

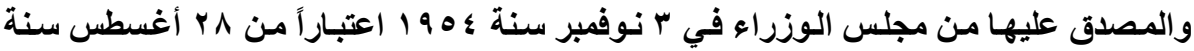


ولا يعترف قـانون العقوبـات المـصري سـوي بـالأثر السلبي للأحكـام الجنائيـة الأجنبية الصادرة بالإدانة أو بالبراءة بشروط معينة نصت عليها المادة الرابعة من هذا القانون. وفيما خلا قوة الحكم الجنائي الأجنبي من ناحية أنه يحول ـ في الغالب ـ دون إعادة المحاكمة عن نفس الواقعة من جديد، متى كان نهائيا سواء بالنسبة للمصريين أم للأجانب، فإنه من المقرر في العرف الدولي حتى الآن أنـه ليس للأحكام الجنائية بوجه عام من قوة خارج إقليم البلد الذي صدرت فيه؛ فهي غير قابلة للتفيذ إلا في البلد الذي صدرت فيه ، ولا يعتد بها كسوابق في العود، فلا يطلب عنها بالتالي رد الاعتبار في بلا أجنبـي. إلا أن المسادة ب ا مسن قـانون العقوبـات الايطـالي تجيز اعتبـار الحكم الجنـائي الأجنبي سـابقة في العود، وفي الحكم بتدابير وقائية معينة، فضلا عن تطبيق بعض العقوبات التبعية. لكن يلزم لذلك أن تكون هناك معاهدة تسليم للمجرمين مع الدولة التي صدر فيها الحكم الأجنبي، أو أن يطلب وزير العدل اعتماد الحكم الأجنبي وترتيب آثاره التي بيذها القانون. كما لا يعتد بها في شأن تعدد الجرائم وتعدد العقوبات أو عدم تعددها عند التنفيذ، إذا كان المتهم قد حكم عليه في الخارج حكما نهائيا أو غير نهائي ثم عاد إلى وطنه.

ولا تجيز إلغـاء وقف التنفيذ المحكوم بـه فيمـا سبق من المحسكم الوطنيـة قبل

صدور الحكم الأجنبي إذا عاد المتهم إلى وطنـه('). ويضاف إلى ذلك أنها لا تؤدي إلى آثار جنائية أو عقوبة تبعية في الاخل. مثل الحرمان من بعض الحقوق أو المزايا، حتى ولو كان مثلها مقرراً في التشريع الأجنبي الأي صدرت الأحكام تطبيقاً لـه بـل أنـه لا أثثر

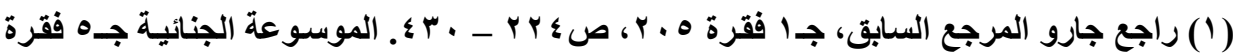

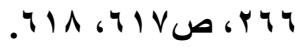

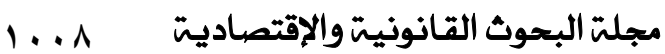


للحكم الجنـائي الأجنبـي في الــعوى المدنيـة التـي قد يقيمهـا المضرور مـن الجريمـة للمطالبة بالتعويض في مصر إلا على سبيل الاستدلال. فهو لا يقيد القاضي المدني فيمـا قد ينتهي إليه من ثبوت الواقعة أو وصفها القانوني أو إسنادها إلى الجـاني، حين أن الحكم الجنائي الوطني يقيد القاضي المدني في كل هذه الأمور وفقا لنص المـادة به ؛ إجراعات جنائية مصري.

\section{وحول أثار الهكم الجنائي الأجنبي يمكن هلاحظة الآتي:}

أولا: الاعتراف بالقوة التنفيذية للحكم الأجنبي ليس نزولا عن السيادة، ولكنه نـوع من التعاون بين الدول في مكافحة الإجرام(')، أمـا اختلاف العقوبـات بين القوانين الجنائية الحديثة فيمكن التظلب عليه بأن تحاول كل دولـة تقرير نوع من التقابل والتعادل بين عقوباتها والعقوبـات المقررة في التشريعات الأجنبية، وقد يكون من الأفضل أن تثقى الدول فيما بينها على ذلك.

ثانيـا: الاعتراف للحكم الأجنبي بالآثار الثانويـة للحكم كالعقوبـات التبعية والتكميلية

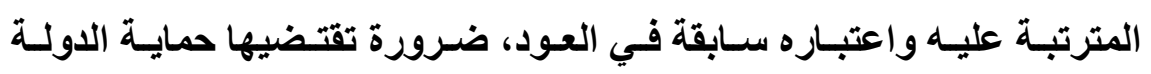
لمصالحها ضد شخص خطر عليها، فمن غير المنطقي أن يحكم على شخص في الخـارج فإذا مـا وجد في إقليم الدولـة وثقت بـه واعترفت لله بحقوق ومزايـا لا يتمتع بها إلا من لم يرتكبوا الجرائم().

(1) Donnedieu de Vabres, no. 1847, p. 1003.

(2) Donnedieu de Vabres, no. 1865, p. 1009. 
ثالثا: يمكن الاعتراف للحكم الأجنبي بقوة الشيء المحكوم فيـه مـع مراعـاة اعتبـارات العدالة التي تقوم عليهـا قاعدة عدم جواز محاكمة شـص من أجل فعل واحـ مرتين والأخذ في الاعتبار الثروط التي يتعين توافرها في الحكم حنى يحوز هذه القوة. رابعا: حق الدولة في مراقبة الحكم الأجنبي قبل أن تعترف لـه بأثر من الآثثار السابقة كي تتحقق من الاختصاص التشريعي والقضائي للاولـة التي أصدرته، ومن أن الاعتر اف به لا يناقض النظام العام.

وعلى الرغم من أن الاعتراف بالأثر السلبي للحكم الجنائي الأجنبي يعد استجابة لقواعد العدالة والإنصاف التي تأبي أن يعاقب الشخص مرتين عن ذات الفعل، إلا أنـه يمكن التمييز في نطـاق التشريعات الجنائيسة بـين اتجـاهين مختلفين: الاتجـاه الأول، يرفض الاعتراف بالأثر السلبي للحكم الجنائي الأجنبي، أما الاتجاه الثاني، فيعترف بهذا الأثر في حدود ويشروط معينة.

الاتجاه الأول : يمثل هذا الاتجاه بعض التشريعات التي ترفض الاعتراف بـالأثر السلبي للحكم الجنائي الأجنبي، بحيث لا يحول هذا الحكم دون محاكمة الثخص وعقابه مرة ثانيـة أمسام المحسكم الوطنيـة عن ذات الفعل أو الواقعة التي صدر بشأنها الحكم الأجنبي(') مثال ذلك ما استقر عليه القضاء في الولايات المتحدة الأمريكية(؟)، وقانون

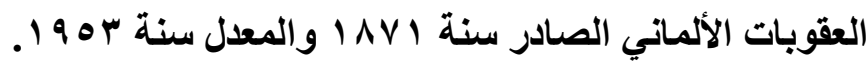
(1) د/ فتحي المصري بكر، قوة الثيء المقضي به في المجال الجنائي، رسالة دكتوراه، كلية الحقوق،

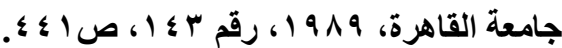

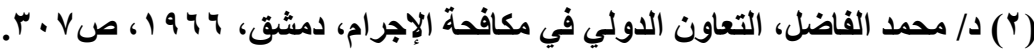


غير أن رفض هذه التشريعات الاعتراف بقوة الأمر المقضي للحكم الجنـائي

الأجنبي، لـم يحل دون اتجاهها إلى محاولـة التخفيف مـن قسوة هذا الاتجـاه مراعـاة لاعتبارات العدالة والإنصاف التي تتأذي من محاكمة الشخص وعقابه أكثر من مرة عن ذات الفعل. وقد اتبعت هذه التشريعات في ذلك أحد طريقين أولها هو إلزام القاضسي عند الحكم على الثخص للمرة الثانية عن ذات الجريمة أن يأخذ بعين الاعتبار العقوبة التي قضي بها الحكم الجنائي الأجنبي، والتي قام الشخص بتنفيذها في الخـارج. وثثانيها هو الأخذ بمبدأ الملاعمة في تحريك الدعوى الجنائية عن الجرائم التي تقترف في الخـارج، بحيث يكون للنيابة العامة سلطة تحريك الدعوى الجنائية عن هذه الجرائم، أو الإحجام عن ذلك متى رأت ذلك ملائماً '( )

الاتجاه الثـاني : تذهب غالبية التشريعات الجنائيـة، استجابة لقواعد العدالة والإتصاف التي تتأذي من محاكمة الثخص وعقابه أكثر من مرة عن ذات الفعل، إلى الاعتراف بالأثر السلبي للحكم الجنائي الأجنبي(؟). مثال ذلك قانون العقوبـات الفرنسي

(1) Repik (B.): Rapport de Tchecoslovaquie, In - Structures et methods de la cooperation repressive internationale et regionale a l'exclusion de l'extradition, Actes du Colloque preparatore au XIIIe Congres internationale tenu a Strasbourg (France) 5-7 Septembre 1983, R.I.D.P, P. 365 et 366.

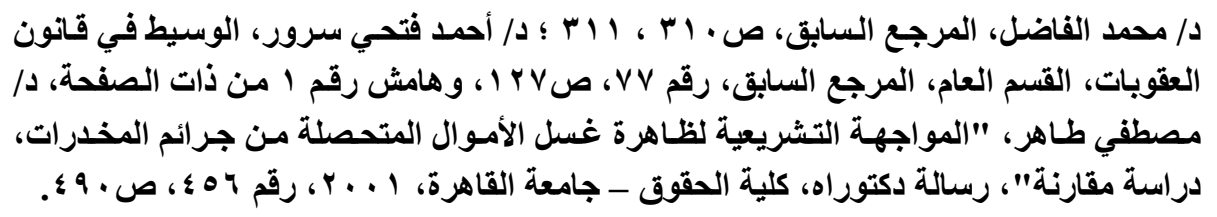
(2) Donnedieu de Vabres (H.): op. cit., p. 463. $=$ 


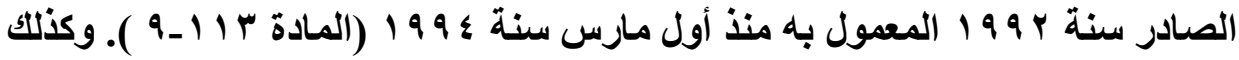
قانون العقوبات المصري (المادة ؛).

غير أن اعتراف غالبية التشريعات الجنائية بقوة الأمر المقضي للحكم الجنـائي الأجنبي ليس مطلقاً، إذ ثمة حدود لهذا الاعتر اف، وثمة شروط يتعين تو افرهـا لتحققه، وعلى ذلك تختلف خطة هذه التشريعات بشأن تحديد نطاق الاعتراف بـالأثر السلبي

$$
\text { للحكم الجنائي الأجنبي (') }
$$

فالمشرع الفرنسي، على سبيل المثال، يقصر الاعتراف بقوة الأمر المقضي للحكم الجنائي الأجنبي، على الأحكام الصادرة بشأن الجنايـات والجنح التي تقترف في

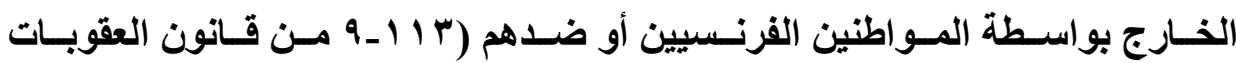

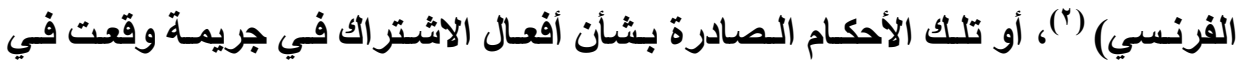
الخـارج، ولـو ارتكبـت هـذه الأفعـال في فرنسـا (المـادة ب ج 9 مـن قـانون الإجـراعات الفرنسي) (). ويشترط للاعتراف بالأثر السلبي للحكم الجنائي الأجنبي في هذه الحالة،

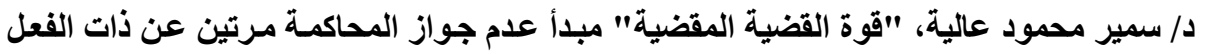

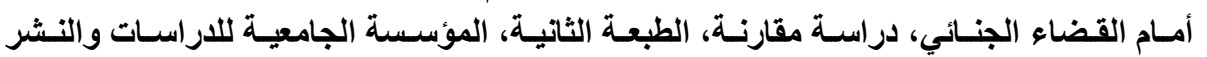

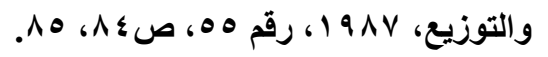

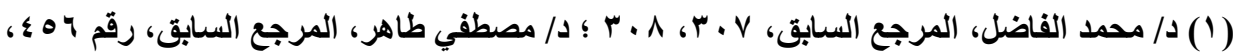
ص.

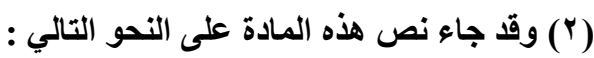

"Dans les cas prevus aux articles 113-6 et 113-7, aucune poursuite ne peut etre exercee contre une personne justifiant qu'elle a ete jugee definitivement a l'etranger pour les memes faits et en cas de condammation, que la peine a ete subie ou prescrite".

(ّ) وقد جاء نص هذه المادة على النحو التالمي: $=$ 
أن يكون هذا الحكم باتاً وأن يثبت في حالـة الحكم بالإدانـة، أن المحكوم عليه قد نفذ العقوبة أو أنها سقطت بمضي المدة(') أما بالنسبة للأحكام الجنائية الأجنبية الصادرة بشأن الجرائم المقترفة في الإقليم الفرنسي، وتلك الصادرة بشأن الجرائم المقترفة في الخارج، والتي تشكل اعتداء على المصالح الأساسية لدولة الفرنسية، ويطبق عليها قانون العقوبات الفرنسي وفقا لمبدأ العينية الذي نصت عليه المادة (س 1 1 ـ ـ 1) من قانون العقوبات الفرنسي. فإنها تتجرد من قوة الأمر المقضي، بحيث لا تحول، رغم تنفيذ العقوبـة المحكوم بها في الخـارج، دون إمكانية محاكمة التي قضي بها"(؟).

Art. 692. : "Dans les cas prevus au chqpitre precedent, aucune poursuite ne peut eter execrcee contre une personne justifiant qu'elle a ete juge definitivement a 1, etranger pour les memes faits et, en cas de condammation, que la peine a ete subie ou prescrite".

Huet (A.) et Koering-Joulin (R.): op. cit., no. 153, p. 231 et 232.

(1) Huet (A.) et Koering-Joulin (R.): op. cit., no 154 et s, p. 232 et s; Desportes (F.) et Le Gunehec (F.) L Le nouveau droit penal, T.I, Droit penal general, Economica, 1994, no. 398 ets, p. 292 et s; Pradel (J.); Droit penal general, $9^{\mathrm{e}}$ ed., Cujas, 1994, no. 238, p. 265 et 266.

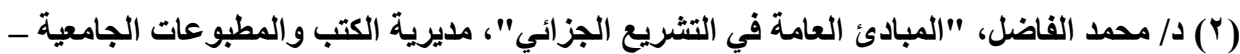

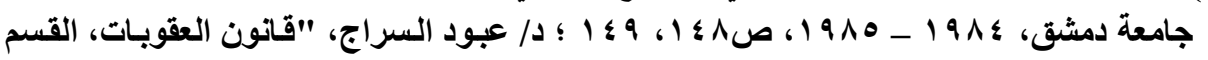

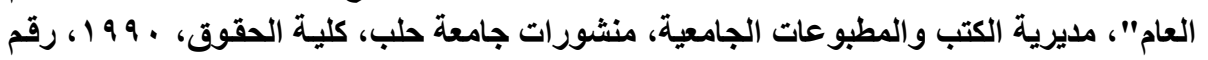


أمسا المشرع المصري، فقد تبنى خطة أكثر مرونـة في مجـال الاعتراف بـالأثر السلبي للحكم الجنـائي الأجنبي (')، إذ اعترف بقوة الأمسر المقضي للأحكـام الجنائيـة الأجنبية الصادرة بشأن الجرائم المقترفة خارج الإقليم المصري، والتي يطبق عليها قـانون العقوبـات اسـتنـاداً إلسى مبـدأي العينيـة (المسادة الثانيـة مـن قـانون العقوبـات)، والثخصية (المـادة الثالثة مسن قـانون العقوبـات)، سـواء كانـت هذه الأحكام صـادرة بالبراءة أو الإدانة. وقد اشترط المشرع للاعتراف بقوة الأمر المقضي للحكم الجنـائي الأجنبي في هذه الحالة، أن يكون هذا الحكم نهائيا، وأن يكون المحكوم عليه، في حالة الإدانة، قد استوفي تنفيذ العقوبة المحكوم بها في الخارج(؟). وعلى الرغم من اعتراف المشرع المصري بقوة الأمر المقضي للأحكام الجنائية الصادرة بشأن الجرائم المقترفة في الخارج، على نحو ما أشارت إليه المادة الرابعة من قانون العقوبـات، إلا أن تطبيق هذه المـادة قد أثثار التساؤل حول المقصود باستيفاء العقوبة الذي يحول دون إعادة محاكمة الشخص مرة أخرى عن ذات الفعل أمام القضاء

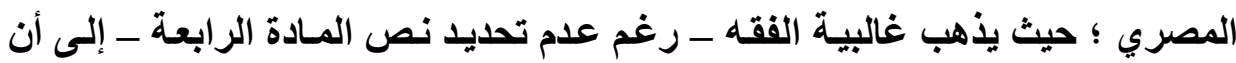
تنفيذ العقوبـة يجب أن يكون كاملا. ويعنى ذلك، أنه لا مجـال للاعتر اف بحجية الأمر المقضي للحكم الجنائي الأجنبي التي تحول دون إعادة المحاكمة مرة أخرى أمام القضاء المصري، إذا لم تنفذ العقوبة المحكوم بها ابتداع، أو نفذت بصورة جزئية، أو سقطت بمضي المدة، أو صدر عفو عنها"). ورغم ذلك، يري بعض الفقه، وبحق، أن الاستيفاء

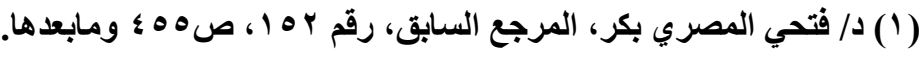

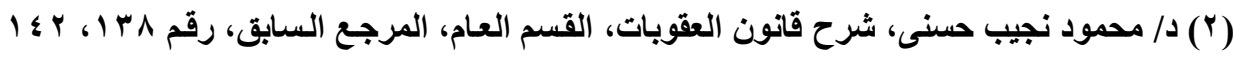
ومابعدها.

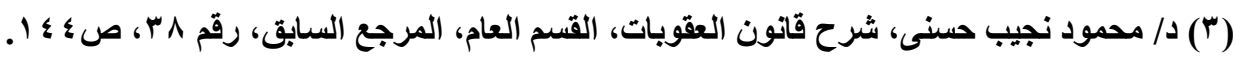


الكامل للعقوبة يجب أن يتم في ضوء نصوص القانون الأجنبي، وأن تقادم العقوبة أو العفو عنها هو في حكم تنفيذها قانوناً، استتاداً إلى أن القياس جائز لمصلحة المتهر ('). وتجدر الإشارة، إلى أن المشرع المصري لم ينص، وعلى خلاف ما فعلت بعض

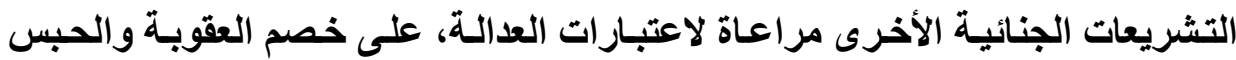
الاحتياطي اللذين تم تنفيذهما بالخارج من أصل العقوبة التي يقضي بها القضاء الوطني

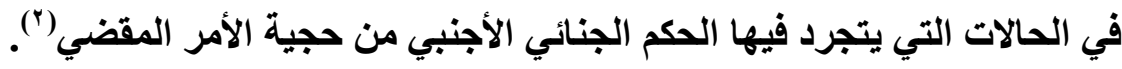
أمسا غالبيـة التشريعات الجنائيـة فتـرفض فـي غيـاب اتفاقيـة دوليـة ثنائيـة أو

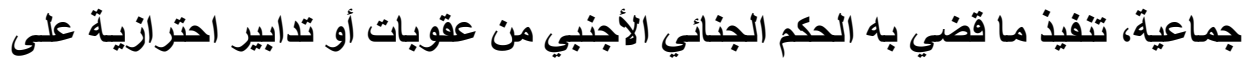
إقليمها. بل وترفض كذلك الاعتداد بهذا الحكم كسابقة في العود، أو الاستناد إليه في إلفـاء وقف تنفيـذ العقوبـة المحكوم بهـا من المحسكم الوطنيـة، أو في مجـال تطبيق

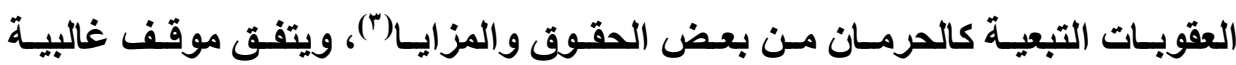
التشريعات الجنائية في هذا الصدد مع الاتجاه السائد في الفقه التقليدي، والذي يري في الحكم الجنائي تجسيداً لسيادة الاولة التي أصدرته، وفي تنفيذ هذا الحكم في إقليم دولية أخرى مساساً بسيادة هذه الأخيرة يتعين عليها عدم قبوله.

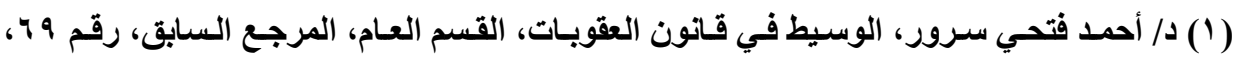

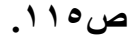

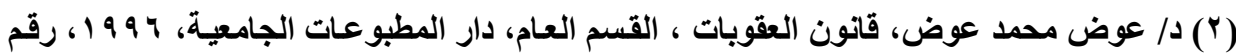

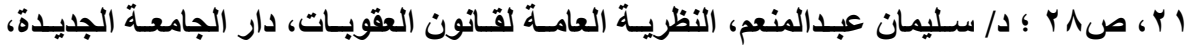

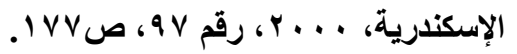

(3) Merle (R.) et Vitu (A.) : op. cit., no. 337, p. 447.

مجلتّ البحوث القانونيت والإقتصادية 10 1. 
يضاف إلى ذلك، أن عدم الاعتراف بـالقوة التنفيذية للحكم الجنائي الأجنبي، لا يحول دون أخذ القاضي الفرنسي لهذا الحكم في الاعتبار كواقعة أو مصدر للمعلومـات يستعين به، بالإضافة إلى العناصر الأخرى، في تحديد للجزاء الجنائي الملائم لإصلاح المحكوم عليه وإعادة تأهيله، وفي تحديده كذلك لمدي جدارته بوقف التنفيذ('). والمششرع المـصري، وإن رفض الاعتـراف بالآثـار الإيجابيـة للحكم الجنـائي الأجنبي، إلا أنها اعترف، استثناء، ببعض الآثار غير المباثرة التي تترتب على هذا الحكم. مثال ذلك، ما نصت عليه المادتان الرابعة والسابعة من القانون رقم ب^ه لسنة هـ 19 بثأن تنظيم المدارس الحرة، من أن الحكم الجنائي الأجنبي الصادر في جناية أو جنحة ماسة بالأخلاق أو الثرف أو الأمانة يعد مانعاً من جواز امتلاك مدرسـة حرة أو إدارتها أو الاشتغال بها بالتدريس أو بأي عمل آخر من أعمال التعليم أو الإشراف أو

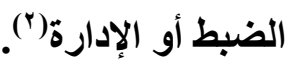

(1) Huet (A.) et Koering-Joulin (R.): op. cit.,no. 227, p. 327.

انظر في التمييز بين تتفيذ الحكم الجنائي الأجنبي، ومجرد أخذه في الاعتبار،

Ropers (J.L.): art. Prec, J.C.P., No. 1797.

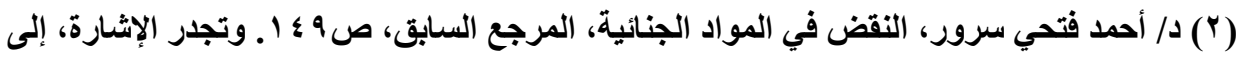

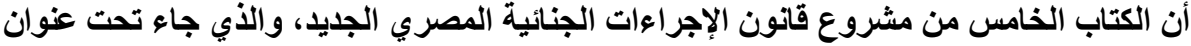

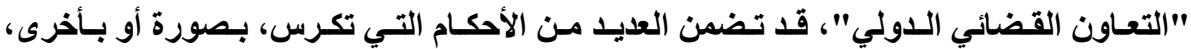

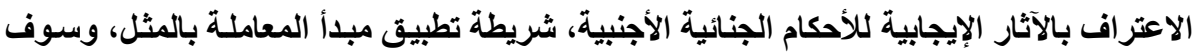

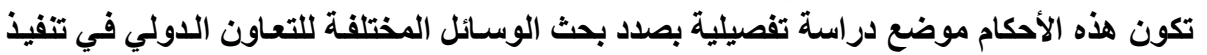
الأحكام الجنائية الأجنبية. 


\section{المبحث الثالث}

\section{طبيعة المررات الرسبهية الأجنبية}

تظهر أهمية المبأ المقرر لرفع الصفة الرسمية عن المحرر الأجنبي الرسمي من أنه يتطرق لوضع لم تتم معالجته من قبل المشرع بنصوص جرائم التزوير الواردة

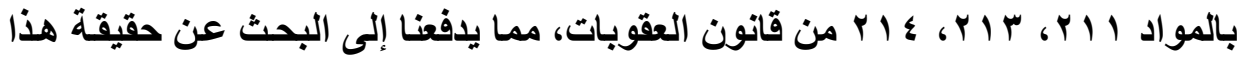
المبدأ من خلال الإجابـة عن مجموعة من التساؤلات تدور حول ماهية المعيـار الللازم للقول برسـية المحررات والاتجاهـات الققهيـة والقضائية المتباينـة حـول رسـمية أو عرفية المحرر الأجنبي وأساتيدها ، وإلى أي حد يمكن قبولها من عدمه. إن الإجابة على تلك التساؤلات تقتضي التعرض لمبدأ رفع الصفة الرسمية عن المحرر الأجنبي الرسمي" من خلال البحث في نقطتين أساسيتين : النقطة الأولي تثعلق ببيان أسـاس هذا المبدأ وهو اعتمـاد الموظف العـام المختص للمحرر لإضفاء الصفة هنة الرسمية عليه فنعرض فيه لطبيعة هذا الاعتمـاد من خلال بيـان صفة القائم بـه وأثره. والنقة الثانية تتعلق بنقد المبدأ من خلال بيـان حقيقة التحول القضائي والاتجاهـات الفقهية والقضائية المؤيدة والمعارضة له.

\section{المطلب الأول}

أساس المبدأ (هناط راسمية المهرر اعتماد الموظف العام المفتص)

اعتمد المشرع المصري في سياسته المتعلقة بتجريم التزوير في المحررات

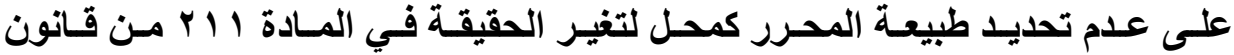


العقوبـات، والتي من شـأنها أن تنصرف في بنائها القانوني لجميع المحررات سواء كاتت رسمية أو عرفيه أو بنكية، ثم تطرق في نص المادة ؛ اب لعقوبـة التزوير الوارد على المحرر الرسمي من دون أن يقوم بوضع تعريف محدد لهذا الأخير. الأمر الأي دفع الفقه إلى تعريف المحرر الرسمي بأنه "المحرر الذي يصدر من موظف عام مختص، سواء كانت البيانات التي تضمنها تفيد ما تم على يايه من وقائع، أو تثير إلى ما تلقاه من ذوي الثأن من أقوال(') كما عرف أيضا بأنه "المحرر الذي يحرره موظف عام مختص أو يتلخل ليسبغ عليه الصفة الرسمية وفقـا لمـا تقضي بـه الأنظمة واللوائح(")

ويقصد بالتزوير تغيير الحقيقة في محرر يحميه القانون باحدي الطرق المقررة

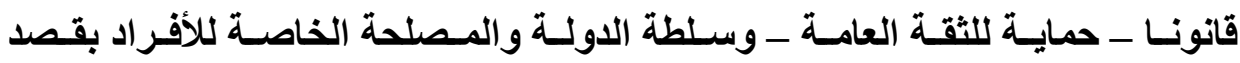
استعماله فيما حرر من أجله توقيا للضرر المحتمل المـاس بـالحقوق أو المصالح التي يعبر عنها هذا المحرر. فالخطر أو احتمال الضرر هو النتيجة القانونية لتغيير الحقيقة (النتيجة المادية) في محرر يحميه القانون(")

(1) د/ أحمد فتحي سرور، الوسيط في قانون العقوبات، القسم الخـاص، دار النهضة العربيـة، الطبعة

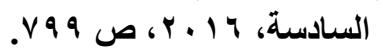
(ץ) د/ أحمد لطفي السيد مرعي، جرائم التزوير في المملكة العربية السعودية، جامعة الملكت سعود،،

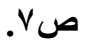

http://faculty.ksu.edu.sa/ahmedmarie/pages.

راجع في تعريف المحرر الرسمي. د/ عبد الحميد الشواربي، التزوير والتزييف مدنياً وجنائياً في

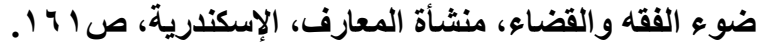
(r) حول تقدير احتمال الضرر كشرط لتجريم التزوير. راجع د/ أحمد فتحي سرور، الوسيط في قانون

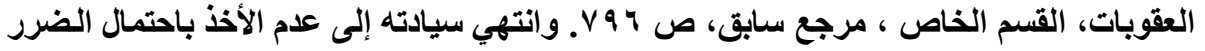
$=$

مجلت البحوث القانونيت والإقتصاديت 1 1 . 1 
ومن جانبه فقد ذهب القضاء إلى أن مناط رسمية المحررات يرجع إلى أن يكون محررها موظفا عمومياً مختصا بمقتضي وظيفته بتحرير هـا و إعطائها الصفة الرسمية أو بالتداخل فيها أو التأثشير عليها وفقاً لما تقضي بـه القوانين أو اللوائح أو التعليمـات التي تصدر إليه من جهته الرئاسية ، كما لا يلزم صدورها فعلا من الموظف المختص بتحرير ها و إنما يكفي لتحققها إعطاء الورقة شكل أو مظهر الورقة الرسمية الصادرة من الموظف العام المختص (') - من وباستقرار الموقف الفقهي والقضائي مسن تعريـف المحرر الرسـي نستطيع تحديد أن الأصل في اعتبار المحرر محرراً رسمياً أن يتم اعتمـاده من قبل موظف عام مختص، فالاعتماد هو الإجراء الذي من شأنه أن يعطيه الصفة الرسمية، والذي يستلزم لبيان ماهيته الوقوف على نقطتين أساسيتين : النقطة الأولي تتعلق بصفة القائم بـه. والنقطة الثانية بأثره. وعلى على النحو التالي:

\section{الفرع الأول}

\section{شروط القائم بالاعتماد}

يستلزم الفقه والقضاء توافر شرطين أساسين بمن يظهر اعتمـاده على المحرر

لإضفاء الصفة الرسمية عليه : الشرط الأول، أن يكون موظفاً عاما. والثرط الثاني، أن يكون مختصاً. ولا يلزم لتحقق هذين الشرطين أن يصدر المحرر من الموظف العسام

كثرط مستقل في جريمة التزوير. أما النتائج التي يعزوها الفقه إلى فكرة الضرر فإنها ترتدا إما إلى إلى عنصر تغيير الحقيقة أو إلى ما يجب أن يتوافر في طبيعة المحرر الذي كان محلا للتزوير.

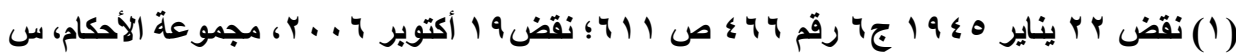

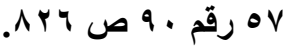


المخـتص. ولا يلـزم لتحقـق هـذين الـشرطين أن يـصدر المحرر مسن الموظف العـام المختص، بل يكفي أن يتم نسبته إليه إذا ما أصدره أحاد النـاس(') فالعلاقة قائمسة بين فكرتي المحرر الرسمي والموظف العام ومناط ذلك أن المحرر الرسمي يعبر عن إرادة الاول بمؤسساتها، وأن الموظف العـام هو الشخص المخول بـالتعبير عن تلكك الإرادة، مع التأكيد على أن ظهور تلك العلاقة لا يعنى بالضرورة أن يتدخل الموظف العام بنفسه على المحرر ليكون محرراً رسمياً، بل من الممكن أن ينسب له زوراً(؟).

\section{هدي قبول اعتبار المكلف بالفدهة العاهة هوظفـا عاهـا في جريمة التزويـر في}

المررات

إذا كان من شـأن كل من يعمل في مؤسسات الدولـة أن يتمتـع بصفة الموظف

العـام، فإن صفة من يقوم بالعمل خـارج تلكك المؤسسات تبدو غامضة فيمـا لو تلدخل

بـالتعبير عن إرادة الدولـة من خـلال قيامسه بعمل مـا داخل مؤسساتها، وهذا هو شـأن المكلف بخدمة عامة"(") فهل يتمتع بصفة الموظف العام فيضفي تلخله الصفة الرسمية

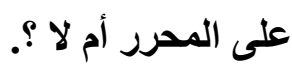

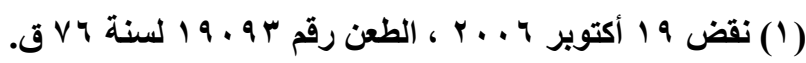

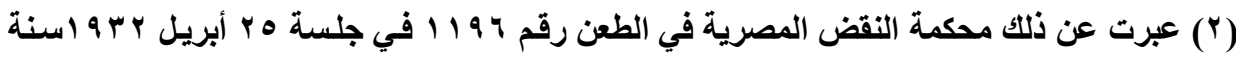

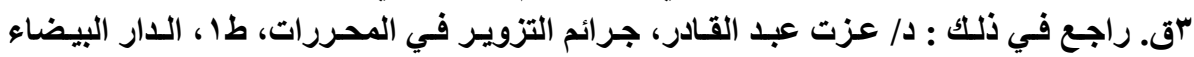

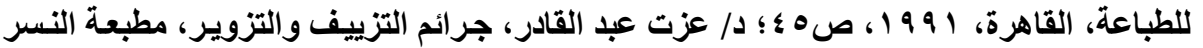

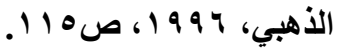

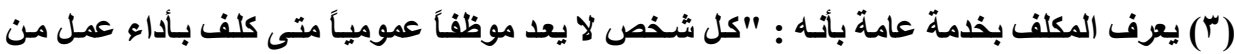

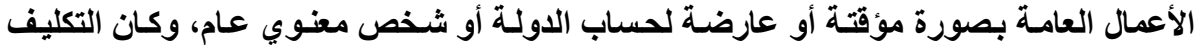

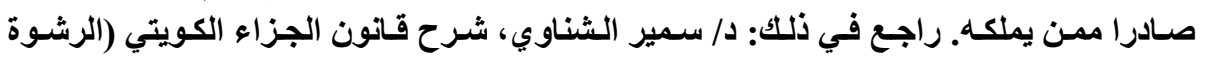

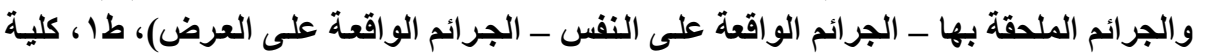

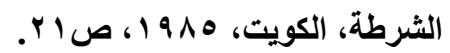

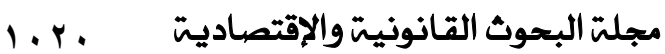


للإجابة على ذلك يلزم بيـان أن المشرع المدني من خلال المـادة العاشرة من قانون الإثبـات قـ سـاوي بين المحرر الصـادر عن الموظف العـام والمكلف بالخدمـة

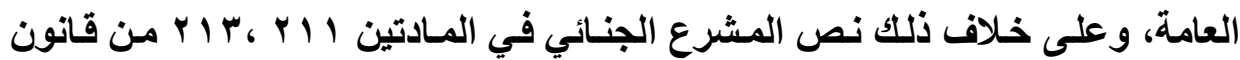
العقوبات علي رسمية المحرر الصدر فقط من الموظف العام دون أن يتضمن المكلف بخدمـة عامـة. ويستخلص مـن ذلك أن منــاط العقـاب علـي تغيير الحقيقـة في الورقـة الرسمية هو صدورها من موظف عام مكلف بتحريرهـا استنـادا لمقتضيات وظيفته. وقضاء النقض بعدم نص المشرع صراحة علي اعتبار الموظف العام كـالمكلف بالخدمـة العامة في باب التزوير خلافا لما اتبعه في المادتين 11 | 1 ، 11 أعقوبات بشأن جرائم الرشـوة واختلاس المـال العـام والعدوان عليهه مردود عليهه بأنسه في الأخير لـم يشمل بالحماية مصلحة قانونية سبق أن عرفها قانون آخر، الأمر الذي استلزم تحديد نطاق المصلحة التى يشملها بالحمايـة(') فضلا عن وجوب التقيد بتعريف الورقة الرسمية الوارد في الفصل الخـاص بـالأوراق الرسمية في المـادة العاشرة مـن قـانون الإثبات حرصا علي التكامل القانوني وتساند التعريفات القانونية مع بعضها البعض داخل فروع

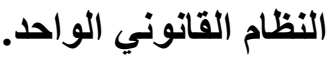

كما أن المشرع المصري لم يتطرق في معرض النص على جريمـة التزوير في المحررات إلى تعريف محدد للمقصود بالموظف العام، فقد اكتفي بـأن جعل تلك الصفة من الأسباب المشددة للعقوبـة على نحو مـا جـاء بنص المسادة ـ اب عقوبـات، وعليه يترتب بقاء الوضع غامضاً بالنسبة للمكلف بخدمة عامة في مدي قبول اعتباره موظفاً

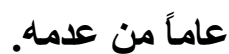


ولإزالة الغموض عن وضع المكلف بخدمة عامـة يلزمنـا ابتـاء بيـان نقطتين: النفقـة الأولـي، أن السياسة التـي انتهجهـا المششرع المـصري في التعامـل مـع صـفة الموظف العام في جريمة التزوير في المحررات الرسمية لم تكن تلك التي انتهجها في جرائم الرشوة والجرائم الملحقة بها وجرائم الاعتداء على الأمسوال العامـة، والتي أفرد فيها بنص خاص مفهوماً للموظف العام شمل طوائف متعددة كان من ضمنها المكلف بخدمة عامة، ما يفيد بأن اعتبار هذا الأخير موظفا عاماً من عدمه مسألة لا يحتكم فيها

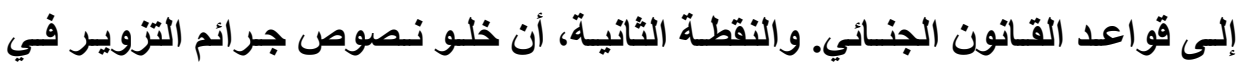
المحررات من النص على اعتبار المكلف بخدمة عامة موظفاً عاماً مسألة من شـأنها أن تركت الباب مفتوحاً أمام التجاذب القضائي والفقهي في اعتباره موظفاً عاماً من عدمـه. فقد وسعت المـادة 1 | 1 عقوبـات من دائرة من يندرج تحت صفة الموظف العـام لكن المشرع لم يسلك السبيل ذاته بالنسبة لجريمة التزوير ، واقتصر في تثديد العقاب علي

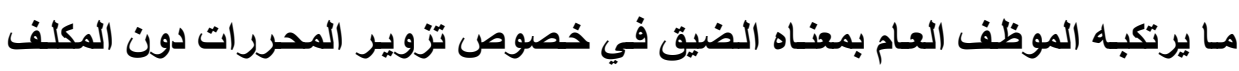
بخدمة عامة أو الموظف في القطاع العام. ولهذا قضت محكمة النقض باستبعاد المكلف بخدمة عامة من دائرة الموظف العام في باب التزوير.

وحقيقة الأمر أن هنـاك اتجـاه قضائي وآخر فقهي حول مسألة قبول الاعتر اف

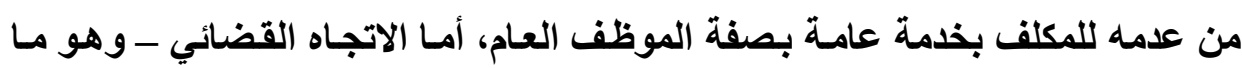
سارت عليه محكمة النقض المصرية(') ـ فيذهب إلى اقتصار صفة الموظف العام على

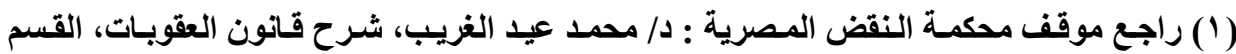

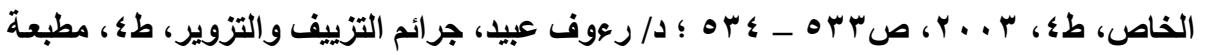

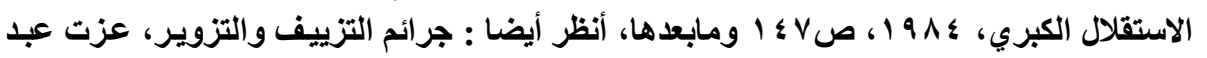

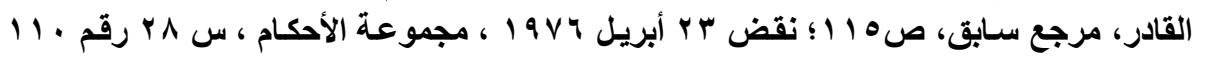


مـن تتحقق فيـه شـروط الموظف العـام وفةًا للمعنى الخـاص بالقـانون الإداري، والتـي تتطلب أن يعمل الشخص بصفة دائمسة في خدمـة مرفق عـام أو مصلحة عامـة تـار بطريقة الإدارة المباثرة بعد أن عهد له بنصيب من السلطة، مما يستعبد المكلف بخدمة عامة من عداد الموظفين العموميين، وحجة ذلك مراده إلى نقطتين : النقطة الأولي، أن المشرع لو أراد للمكلف بخدمة عامة أن يتمتع بصفة الموظف العام في جريمـة التزوير لنص عليه صراحة على غرار ما أراده له في جرائم أخرى كجريمـة الرشـوة والجرائم الملحقة بها.

والنقطة الثانيـة، أن اكتفـاء نـص المسادة ؛ ا Y المتعلقـة بتحديـ عقوبـة جريمـة التزوير في المحررات الرسـية بـكر الموظف العـام فقط من دون تحديد لـه يقتضي البحث عن معنـاه في القانون الإداري لأنـه القانون الذي سبق وأن أعطي تحديداً لـه بشكل عام، وأنه من غير الصحيح أن يتم اللجوء إلى قانون آخر كالقانون المدني الذي الذي

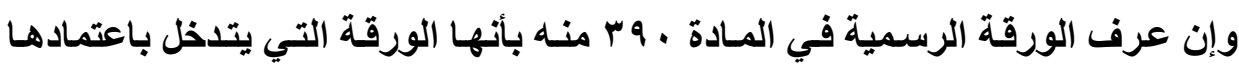

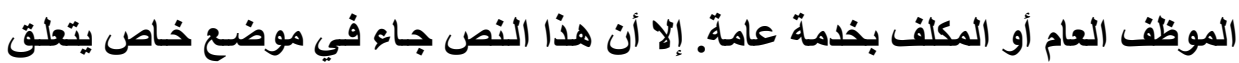
بإثبات الورقة الرسمية، مما لا يجيز تعميم ما ورد فيه على مفهوم الموظف العام. وفي مقابل الاتجاه القضائي، كان هناك اتجاه فقهي - وهو ما نميل إليه - يري

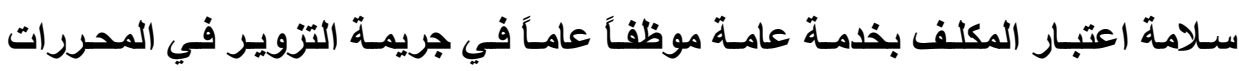
الرسمية، على أساس أن الاستناد إلى تعريف الورقة الرسمية على النحو الوارد في نصوص القانون المدني في مسائل الإثبات أولي من الاستناد إلى تعريف الموظف العام في القـانون الإداري، فالورقة تعتر رسمية في القـانون المداني عند اعتمادهـا من قبل الإنل موظف عام أو من قبل مكلف بخدمة عامة، وحجة هذا الاتجاه ترتكز على نقاط أربع: 
النقطة الأولي : أنه من غير المقبول أن يتم النظر إلى مفهوم الموظف العام منفصلاً عن مفهوم الورقة الرسمية في جريمة التزوير في المحررات الرسمية، فـالربط بينهما منطقي وتكـاملي لتحقيق الغايـة التشريعية من النص التجريمسي وإن لـم يصرح المشرع الجنائي بذلك، و عليه يجب أن يعامل المكلف بخدمة عامة معاملة الموظف العام لاشتر اكهما في مزاولة السلطة بأداة مشروعة صادرة عنها'(') ولذلك فإن التعويل على مفهوم الموظف العام في القانون الإداري من شأنه أن يغيب هذا الربط. والنقطة الثانية، أن عدم تحديد المشرع الجنـائي لموقفه قبل المكلف بخدمة عامة في جريمة التزوير في المحررات الرسمية يحصر الخيار بين مفهومين : الأول يتعلق بمفهوم الموظف العام في القانون الإداري، والذي يخرج المكلف بالخدمـة العامـة مـن عداد المـوظفين العموميين. والثاني يتعلق بمفهوم الورقة الرسمية في القـانون المدني، والذي يشير بشكل صريح على اعتبار الورقة رسمية عندما يتدخل المكلف بخدمة عامة عليها بالاعتماد. وأمام هذين الخيارين المتناقضين كانت دواعي المحافظة على النظام القانوني للاولة تتطلب المحافظة على وحدة التعريفات القانونية(؟). فليس من المقبول أن يتم اعتبار الورقة التي يعتمدها المكلف بخدمة عامة ورقة رسمية في القانون المدني، بينما تعتبر ورقة عرفية في القانون الجنائي("). النقطة الثالثة، أن القول برفض اللجوء إلى نص تعريف الورقة الرسمية في القانون المدني بسبب وروده في موضع خاص يتعلق بقواعد الإثبات مردود عليه بـأن

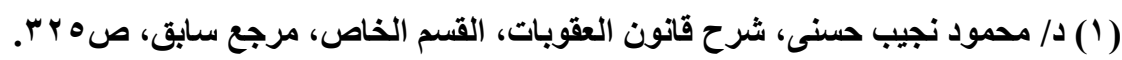

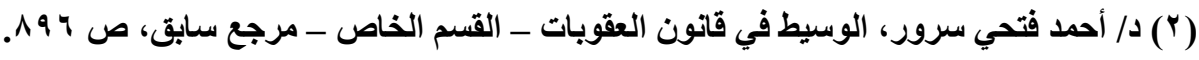

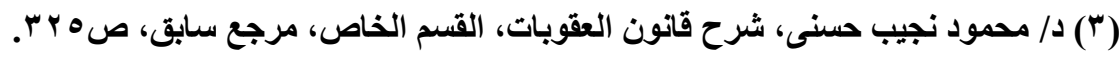


النص قد جاء بثكل مطلق وعام في مقدمة نصوص قواعد الإثبات قبل الخوض في

مدي حجية بيانات المحرر الرسمي التي تطرقت لها نصوص تالية لهل') والنقطة الرابعة، إن قيام المشرع الجنائي بالنص صراحة على المكلف بخدمة عامة إلى جانب الموظف العام في جرائم الرشوة أو الاختلاس أو الاعتداء على الأموال

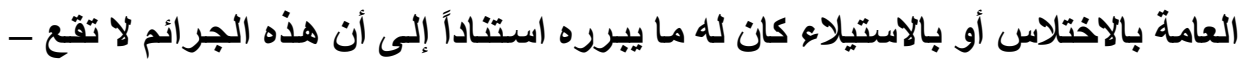
من حيث الأصل - إلا من الموظفين العموميين، فإذا أراد المشرع أن تقع من غيرهم

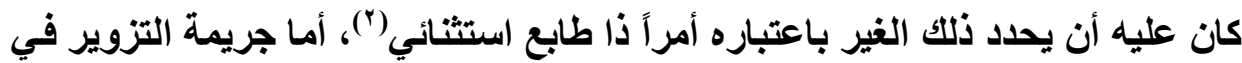
المحررات الرسمية فمن شأنها أن تقع من الموظف العام أو من غيره. وتعقيباً على ما سبق، يظهر لنا وجاهة الاتجاه الفقهي وما استتد عليه من حجج والرامي إلى إضفاء الصفة الرسمية على الورقة بتدخل المكلف بخدمة عامة عليها بالاعتماد، ويمكن لنا أن نضيف إلى حجه ماء يلي : أولاً : أن المشرع الجنـائي وهو في معرض النص على جريمـة التزوير في

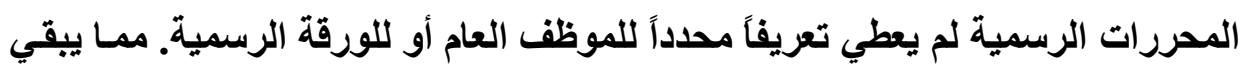
أمر المكلف بخدمة عامة مرهون بالأخذ بأي من التعريفين مما يدعو للقول بأن اللجوء

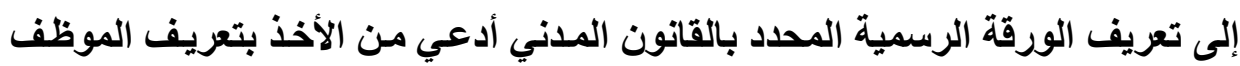
العام بالقانون الإداري، نظراً لأنه يحمل خصوصية محددة تقتضي تقديمه على غيره من

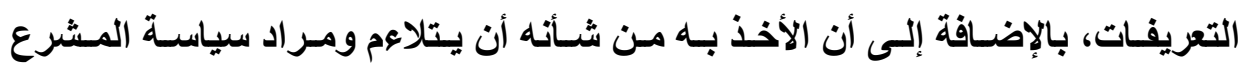

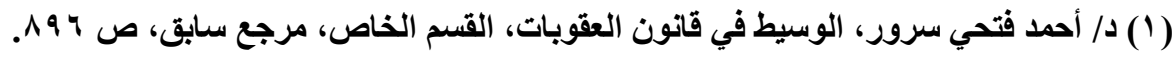

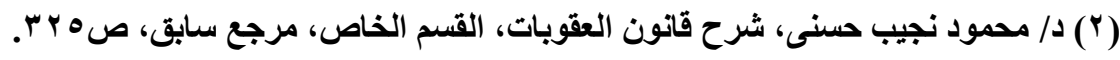


ويتلاقي مع العلة التجريمية التي أرادت أن تجرم التزوير في المحررات الرسمية متى ما ظهر على المحرر اعتماد شخص منحته السلطة نصيباً منها للتعبير عن إرادتها. وثانيها، أن قول محكمة التمييز باستبعاد الاستناد إلى تعريف الورقة الرسمية في القانون المـنـي والمحدد بنص المـادة الثامنـة نظراً لأنـه لا شـأن لـه بأركـان جريمـة التزوير في المحررات الرسمية التي يستقل قانون الجزاء بياناتها قوله تعوزه الدقة'(')، ذلكك أن الحديث عن الورقة الرسمية مسألة أولية تمثل شرطاً مفترضـا لجريمـة التزوير في المحررات الرسـية، ومـن المعلوم أن جميع المسـائل الأوليـة لا تجـد توصـيفاً أو تحديداً لها في القانون الجنائي. وإنما أمر بيانها يرجع إلى قوانين أخرى كما هو في حالة الرجوع إلى القانون المدني لتحديد أحوال انتقال الملكية من عدمها للقول بارتكاب جريمة السرقة، أو إلى قانون الأحوال الشخصية لتحديد ما إذا كان عقد الزواج صحيحاً للقول بارتكاب جريمة زنا الزوج أو زنـا الزوجة. وعليه فلا حرج أن يتم الرجوع إلى نص المـادة الثامنـة لتحديد عناصر الورقـة الرسمية باعتبارهـا شـرطاً مفترضـا لازمـاً للقول بارتكاب جريمة التزوير في المحررات الرسمية. أمسا شرط الاختصاص فيلزم لإضفاء الصفة الرسمية على المحرر أن يكون الموظف العام الذي ظهر اعتمـاده على المحرر مختصاً، ويتحدد الاختصاص الحقيقي من مصادر مختلفة منها: القوانين واللوائح والأوامر الصادرة من الرؤساء سواء كانت مكتوبـة أو شـفهية أو مـن ظروف إنشـائه كمن كـان في وضـع الموظف الفعلي، ولقــ

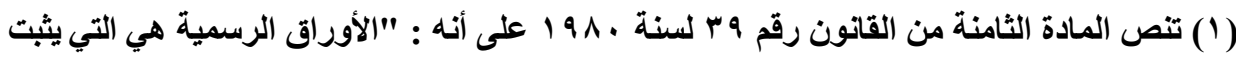

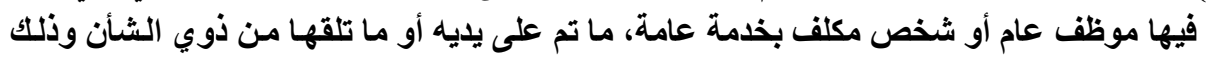

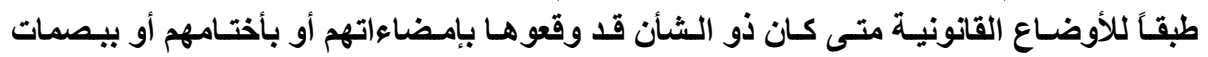

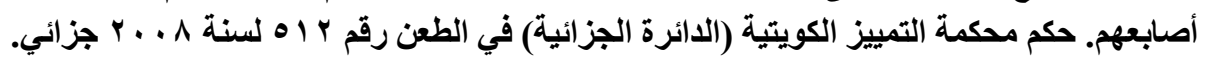


عبرت محكمة النقض عن ذلك بقضائها أن : " هذا الاختصاص لا يستمد من القوانين واللوائح فحسب بـل يستمد كذلك من ظروف إنشاء المحرر أو من جهة صدوره أو بالنظر إلى البيانات التي تدرج به ولزوم تدخل الموظف لإثباتها أو إقرارها...." ("). و إلى جانب أن يكون الموظف العام مختصاً اختصاصاً حقيقياً، فمن الثابت أن يحتفظ المحرر برسميته على الرغم من صدوره أو نسبته إلى موظف عـام غير مختص وذلك في حال إذا ما كان عدم اختصاص الموظف العام غير ظاهر، ويرجع سبب ذلك إلى أن بطلان المحرر لغياب شرط الاختصاص لم يمنعه من أن يفوت على الشخص المعتـاد ويعول عليه. وفي المقابـ، إذا كـان عدم اختصاص الموظف العـام ظاهر فـإن المحرر يفقــ رسـميته بسبب بطلان الظـاهر الذي لا يمكن أن يفوت أو يعول عليه الثخص المعتاد، ولذلك قضي بعدم وقوع جريمة التزوير في المحرر الرسمي واعتبـار الأمر متعلق بالتزوير في المحرر العرفي إذا كان المحرر المزور إثـارة تلفونية منسوب بماب صدورها إلى موظف عـام تتضمن سـؤالاً عن سبب تخلف المتهم عن الاشتراك في

(`) (لانتخابات

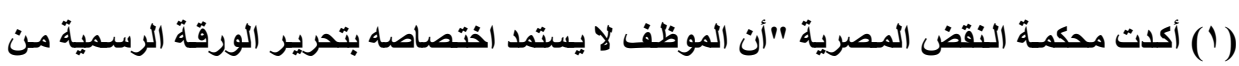

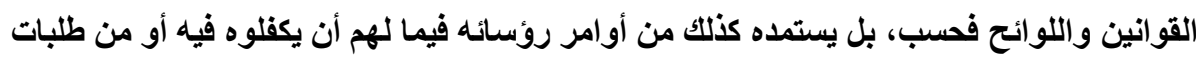

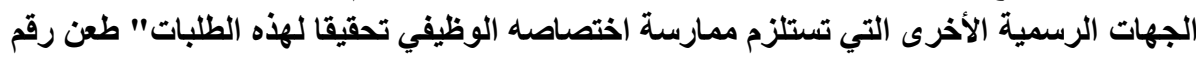

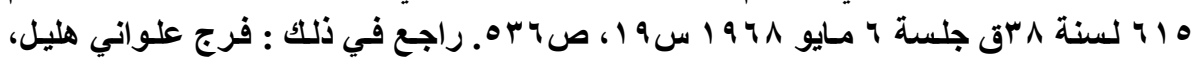

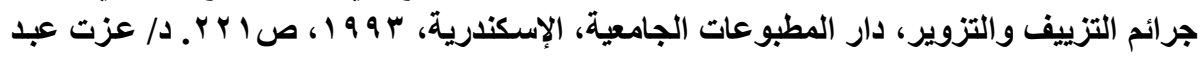

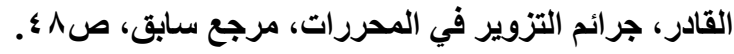

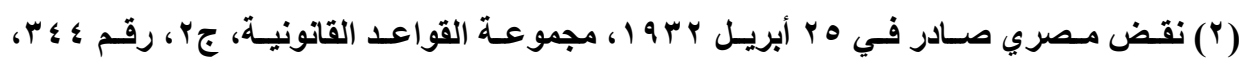
صט• 


\section{الفرع الثاني \\ أثر الاعتمـماد}

يقضي الأصل العام بأن جميع الأوراق التي يظهر عليها اعتمـاد الموظف العام

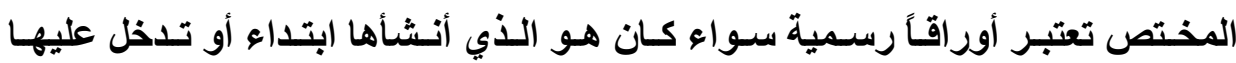
بالاعتماد بعد نشأتها'(')، الأمر الذي يفتح المجـال أمسام مسألة تحول تلك الأوراق بعد اعتمادها إلى أوراق رسمية مزورة، والتي تستلزم التمييز بين وضعين: الوضع الأول يتعلق بالأوراق التي يظهر عليها اعتماد الموظف العام المختص ابتداء سواء كـان هو الذي أنشأها أو نسبت إليه، والتي لا تثير صسوبة في القول بأنها إن ظهرت عليها الحقيقة مخالفة للحقيقة المطلقة التي يجب أن تعبر عنها الورقة الرسمية كاتت الورقة الرسمية مزورة. أمسا الوضع الثاني فيتعلق بالأوراق التي ينشئها الغير على نحو مخالف للحقيقة ابتداء ثم يتدخل عليها الموظف العام المختص بالاعتماد، ونقصد بذلك وضع كل من الورقة العرفيـة المزورة وورقة الإقرار الفردي الكـاذب غير المعاقب عليه، فهل تتحول تلكك الأوراق إلى أوراق رسمية مزورة بمجرد اعتمادها ؟ إن الإجابة عن ذلك تقتضي التمييز بين شكلين من أشكال الاعتماد: اعتماد إدلاء البيانـات ـ التحقق من صحتها والموافقة عليها ـ واعتمـاد صحتها، ولكل منهمـا أثر مختلف على قيام جريمة التزوير في المحررات الرسمية من عدمه. 
يقصد باعتماد إدلاء البيانـات أن يقوم الموظف العـام بمجرد إثبات مـا أدلي بـه مقدم الورقة على مسئولية هذا الأخيز، على أسـاس أنسه غير مكلف بـالتحقق من هذه البيانات، ومثال ذلك أن يقوم موظف الاستقبال باعتماد استلامه للمستتدات المقدمة من صاحب الحاجة تمهيداً لتسليمها إلى الموظف المختص باعتمـاد صحتها، والحال نفسه عندما يثبت الموثث في عقد الطلاق بلسـان المطلق في إثـهار الطلاق بأنه لم يـخل

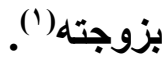
والقاعدة في هذا الثكل من الاعتماد هي عدم قيام جريمة التزوير في المحررات الرسمية، ويرجع ذلك إلى انتفاء احتمالية الضرر كعنصر لازم لقيام الركن المـادي في جريمة التزوير في المحررات الرسمية، فليس من المتصور أن يترتب أثراً ما من شـأنه أن يضر بالمصلحة العامة على اعتماد لم يتم من ورائه فحص البيانـات أو التحقق من

$$
\text { صحتها. }
$$

ثانيًاً : أثر اعتهماد صحة البيانات :

يقصد باعتماد صحة البيانات أن يقوم الموظف بإثبات صحة مـا تقدم بـه مقدم

الورقة من بيانـات تمهيداً لترتيب أثرها الذي قدمت من أجله، فِإن تبين أنها بيانـات كاذبة، كان من شأن مقدمها أن يرتب فعله احتماليـة ضرر بالمصلحة العامـة، ومن ثم تقوم بحقه جريمة التزوير في المحررات الرسمية. فتقديم إقرار عرفي غير صحيح من

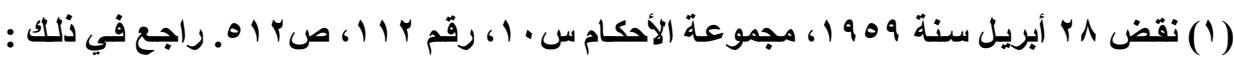

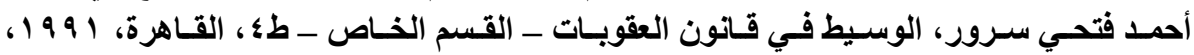


المرشح لرئاسة الجمهورية بأن والدته لا تحمل جنسية أجنبية فإن هذا الإقرار من وقت

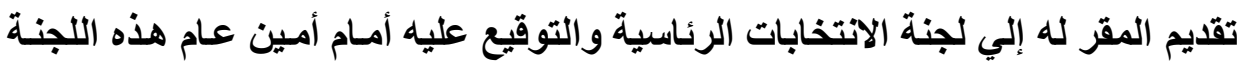

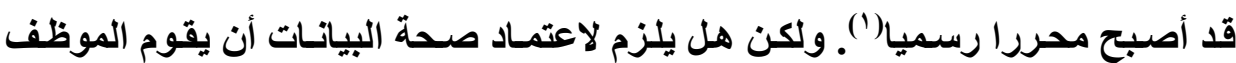
المختص بفصص البيانات و التحقت منها ؟. للإجابـة عن ذلك يلزم التمييز بين نـوعين مـن البيانـات: بيانـات لا يستطيع الموظف فحصها و التحقق من صحتها، وأخرى يستطيع فحصها والتحقق من صحتها. أما البيانات التي لا يستطيع الموظف العام فحصها أو التحقق من صحتها، في تلك التي تحمل أهمية اجتماعية من ناحية، وتتصل بالغير من ناحية أخرى، ويتعذر

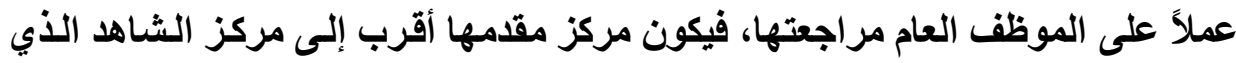
يفترض فيه التزام الصدق. فإن حاد عن ذلك،، واعتمدها الموظف العام، كان التزوير في

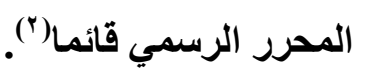
أما البيانات التي يستطيع الموظف العام فحصها والتحقق من صحتها، فالأصل

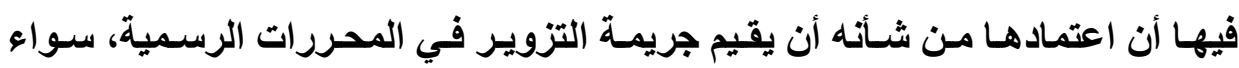
اعتمدها الموظف العام بسوء نية أو بحسن نية، فبان كلان سيء النية اعتبر مسؤولاً

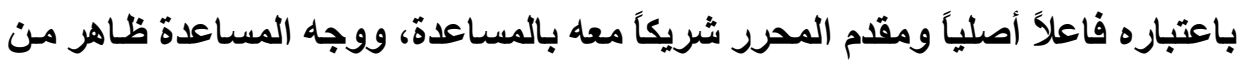
أن الإقرار الكاذب هو الذي سهل للموظف أن يثبت علي خلاف الحقيقة صدق مـا جاء

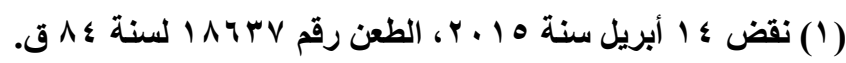

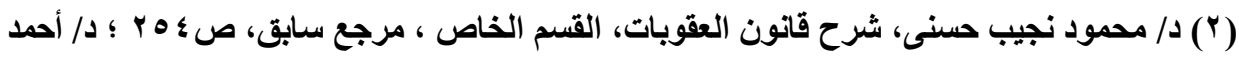

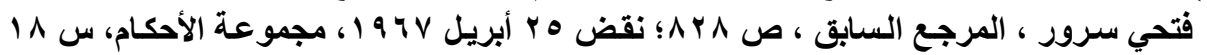

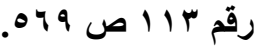


مسن بيانـات، وإن كـان حسن التيـة انتفت مسئوليته وأقيمـت مسسئولية مقدم الإقرار باعتباره هو الفاعل الأصلي (')

بيـ أن الوضـع يختلف فيمـا لـو أهمـل الموظف العـام فاعتمــ البيانـات الكاذبـة المقدمة له على الرغم من قدرته على فحصها والتحقق من صحتها، فقد أجمع الفقهـ والقضاء على أن مغبة التقصير هنا تقع على عاتق من أولاه القانون تمحيص البيانـات

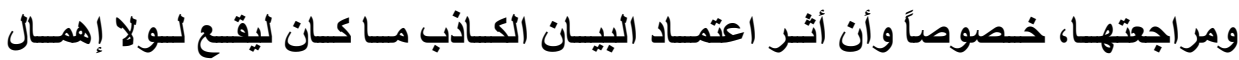

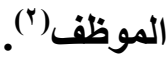

\section{الاطباب الثاني \\ تقيسيم المبدأ}

إذا كان أساس المبأ يقتضي أن يظهر اعتماد موظف عام مختص على المحرر

لاعتباره محرراً رسمياً، فإن غياب شرط الموظف العام أو شرط الاختصاص من شـأنه أن ينـزع صـفة الرسـمية عنـه، ممـا يبقيـه محرراً عرفيـاً ويإسـقاط ذلتك على المحرر الأجنبي نجد أن النظر إليه باعتبـاره محرراً رسميا أو عرفيـا مسألة تختلف وطبيعة النظر إلى طبيعة الموظف العام الأجنبي، ذلك أن قبول اعتبـاره في حكم الموظف العام

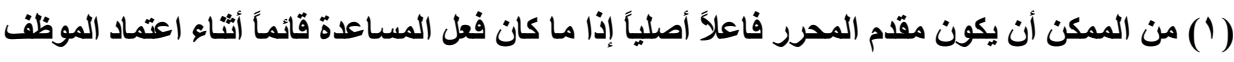

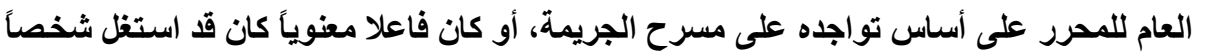

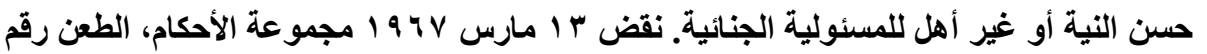

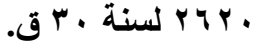

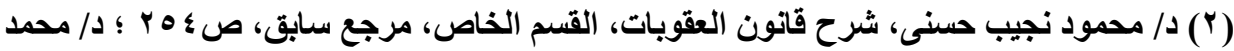

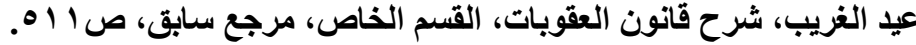


الوطني من شأنه أن يجعل من المحرر الأجنبي محرراً رسمياً، وأن عدم اعتباره كذلك من شأنه أن يبقي المحرر الأجنبي محرراً عرفياً.

وحول حكم المحررات الرسمية الأجنبية التي أصبغت عليها الصبغة الرسمية

وفقا للقانون الأجنبي ثـار الخـلاف القانوني ممـا يقتضي التعرض للاتجاهـات الفقهية والقضائية سواء المعارضة له أم المؤيدة علي النحو التالي:

\section{الفرع الأول}

\section{تهول الإوقف القضائي}

إن غيـاب الدور التشريعي في حسم طبيعة المحرر الرسـي الأجنبي باعتباره

محرراً رسمياً أو عرفياً ترك المجال مفتوحاً للاجتهاد القضائي، الأمر الذي عزز من أن يثهر الموقف القضائي تحولاً مهما. ذلك أن بعض أحكام القضاء المصري ذهبت إلي إعطـاء المحررات الرسـية الأجنبية حكم المحررات الرسمية الوطنيـة مـا دامت هذه الأوراق معترفا لها بالصفة الرسمية في بلادهـا ، فقضت محكمة النقض بالعقـاب علي تزوير شـهادة دبلوم الطب الصادرة من احدي كليات الطب ببلجيكا باعتبار هـا محررا رسـيا(') في حين ذهبت محكمة النقض في أحكام أخري بـأن المحررات الرسـية الأجنبية لا تذخل في حكم المحررات الرسمية الوطنية ؛ حيث قضت بأنه يعد تزويرا في محرر عرفي تغيير الحقيقة في شهادات جمركية بوضع أختام قنصلية وإمضاء كل من

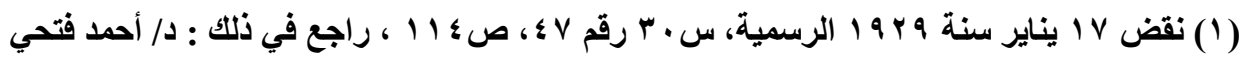

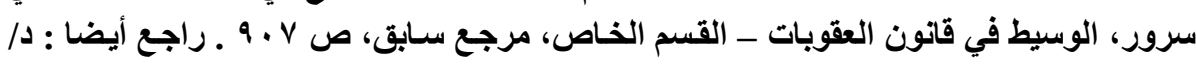

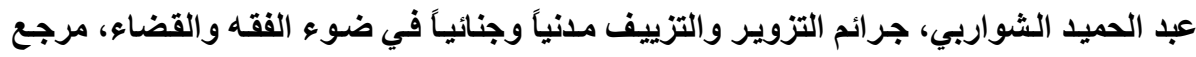
سابق، صس 17 . 


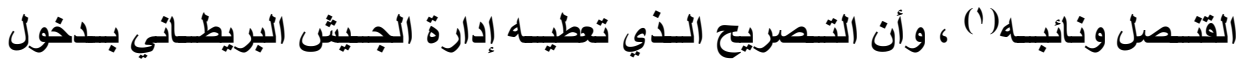

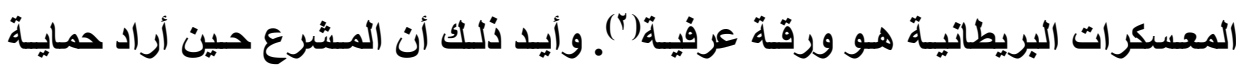
المصالح الأجنبية شـأنه شـأن المصالح الوطنية نص علـي ذلك صراحة كمـا فعل في المـادة r · r عقوبـات المتعلقة بجريمـة التزييف. وأمسام هذين الموقفين المتناقضين لمحمة النقض نجد أن ترجيح أحدهما على الآخر مسألة مبكرة، ذلك أن لكل موقف منها حجج تذعمه من الفقه والقضاء.

\section{الفرع الثاني}

\section{الاتجاهات الفقهية والقضائية القارنة}

إن التوجيه القضائي باعتبار المحررات الأجنبية الرسمية محررات عرفية من المسائل التي لم تجد حسماً فقهياً وقضائياً بالقـانون المقارن، فهي بين اتجـاهين لكل منهمـا حجبـه وأسـاتيده التي تبـرره، فهنـاك مـن يـري بالإبقـاء على الصفة الرسـية للمحررات الأجنبيـة الرسـمية، وفي المقابـل هنـاك مـن يـري بـأن المحررات الرسـية الأجنبية تعتبر محررات عرفيـه، وسـياً نحو الوقوف على مجمل القول في ذلك كان التعرض لنقطتين أساسيتين: النقطة الأولي تتعلق بموقف الاتجـاه المؤيد لبقاء الصفة

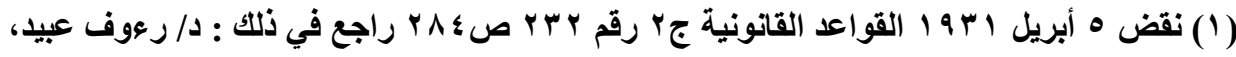

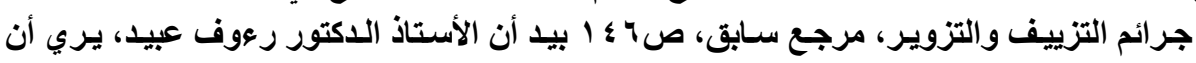

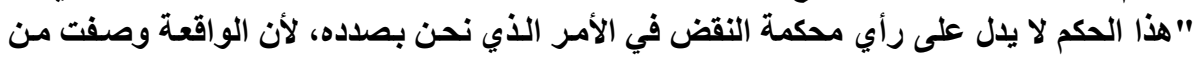
مبدأ الأمر بأنها تزوير في محرر عرفي ـ كما قيدت النيابة الواقعة ـ لا رسمي ولم يكن من مصلحة



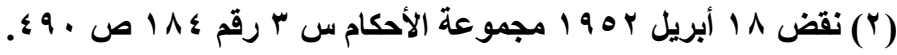


الرسمية للمحرر الرسـي الأجنبي. والنقطة الثانيـة تتعلق بموقف الاتجـاه المعـارض لبقاء الصفة الرسمية للمحرر الرسمي الأجنبي. أولاً : الاتجاه الموئيد لبقاء الصفة الرسمية للاممرر الرسمي الأجنببي: يري أصحاب هذا الاتجاه أن العلة في الإبقاء على الصفة الرسمية للمحررات الأجنبية الرسمية مـرده إلى المصلحة المعتدي عليها عند القيـام بتغير الحقيقة في المحررات، وهي الثقة العامـة التي من شـأنها أن تظهر عليها من خلال طبيعة الجهة الإدارية التي اعتمدت تلك المحررات(') بمعنى أنه متى ما أعطي المحرر الرسمي الأجنبي قيمـة أو ثقة تعـادل قيمة أو ثقة المحرر الرسمي الوطني فيجب أن يأخذ حكمه(؟)، ذلك أن خطورة الآثار التي تترتب على التعامـل مـع المحرر الرسـي الأجنبـي مـن شـأنها أن تجعلهـه في مصاف المحرر الرسمي الوطني(")، فعلى سبيل المثال نجد أن الثهادة الجامعية الرسمية الأجنبية تعادل في قيمتها وأثرها قيمة وأثر الثهادة الجامعية الرسمية الوطنية، وكذلك الحال بالنسبة للأحكام القضائية الأجنبية التي تجوز حجية الأمر المقضي.

(1) Jean PRADEL, Droit penal special, 2 dition, CUJAS, 2004, P. 797. Patrice GATTENGO, doit penal special, 7 edition, COURS, P. 404, Michel VERON, droit penal special, 9 edition, ARMAND COLIN, P 363.

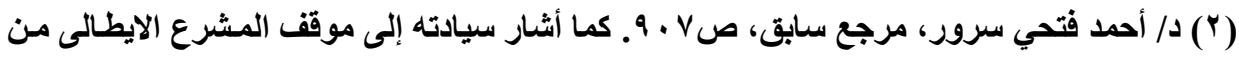

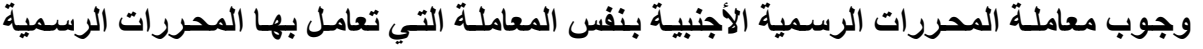
الوطنية منى كان القانون الوطنى يمنح الثقة العامة لهذه المحررات.

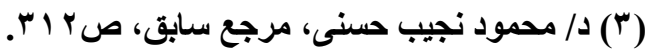


ويعتبر الفقه والقضاء الفرنسي من أبرز الداعمين لهذا الاتجـاه، واللذان يرون

بأن المشرع لم يفرق أصلا في التعامل بين المحررات الرسمية سواء كانت وطنيـة أو

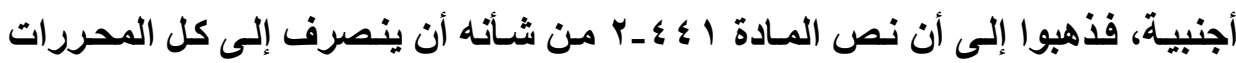
الرسـية بمـا في ذلـك جـوازات السفر الأجنبيـة(') والبطاقـات الشخـصية()، وعليـه

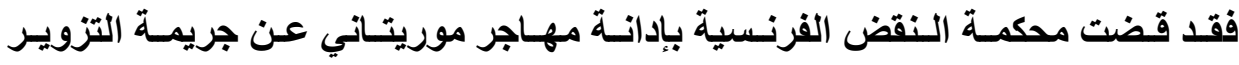
في المحررات الرسمية بسبب قيامسه بـالتزوير في شـهادة جنسيته التي تقدم بها إلى السلطات الفرنسية تمهيداً للحصول على بطاقة الإقامـة ومن ثم الحصول على الجواز

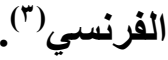
ثانيًا : الاتجاه المعارض لبقاء الصفة الرسمية للهمرر الرسمي الأجنببي : يذهب جانب كبير من الفقه والقضاء المصري إلى أن الصفة الرسمية التي تحملها المحررات إنما تعبر عن إرادة الدولة في مجال تختص به، ولذلك اشترط لتوافر هذه الصفة في المحررات أن تصدر مـن شـص لـه صفة في تمثيل الدولـة، وعليه فـالمحررات الأجنبـة الرسـية تعتبر محررات عرفيـة لأنهـا لا تعكس إرادة السلطة الوطنية بل تعكس إرادة الدولة الأجنبية.

(1) Crime 26 avril 1983, Bull, n 117, Voir: Michel VERON, droit penal special, op. cit, p.363.

(2) Crime 9 octobre 1978, G.P, 1978, II, Somm 354 voir : Jean PRADEL, droit penal special, op. cit, p. 798.

(3) Crime 19 mai 1981, Bull, n 162, R.S.C, 1982. 607. Voir : Andre VITU, Crimes rt delits contre la chose publique, R.S.C, 1984, P. 67 et suivantes.cass.crim 12 fév 1978,J.C.P 1978-2-19260. 
ويرجع أصاحب هذا الاتجاه رأيهم إلى سببين : الأول قانوني، والثاني عملي،

فأما السبب القانوني فمرده أن المشرع إذا مـا أراد أن يعطي للمحرر الأجنبي الرسمي قيمة المحرر الرسمي الوطني فإنه ينص على ذلك صراحة، وذلك على نحو مـا جاء في

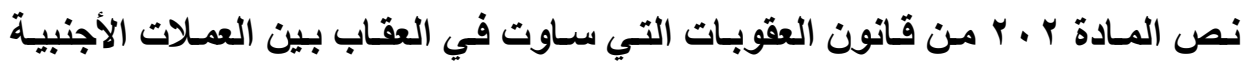
والعملات الوطنية في جريمة التزييف، وبمفهوم المخالفة فإن غياب النص القانوني من شأنه أن يبقي المحرر الأجنبي محررا عرفياً، وهذا ما كان عليه الوضع قبل وجود نص

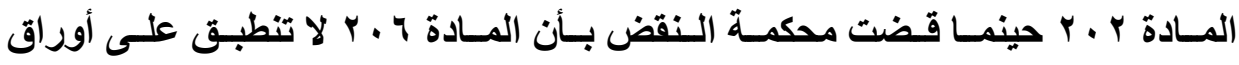
البنكنوت الأجنبية لأن المقصود منها هو حماية المصالح العمومية المصرية(') وفي نفس السياق نجد تقليد أختام الحكومات الأجنبية أو استعمالها يعتبر تقليداً

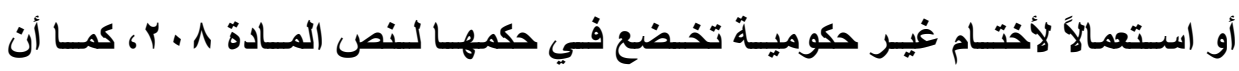
الاستحصال على الصحيح منها بغير حق واستعماله استعمالاً ضاراً يخضع لحكم المـادة

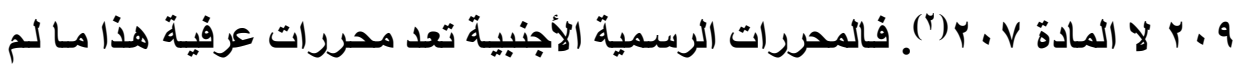
تصدق علي توقيعاتها المـزورة جهة رسـية مسرية، وفي هذه الحالـة فبان مجرد التصديق يجعله محررا رسميا مزورا في حدود مـا شمله التصديق من توقيعات. فبان كان التصديق بحسن نية فإن من قام بالتزوير يعتبر شريكا بطريق المساعدة. وأما السبب العملي فمرده أن الفصل في مسألة رسمية المحرر الأجنبي تقتضي الرجوع إلى قانون بلد المحرر المعرفة مـا إذا كـان يعتبر عندهم من قبيل المحررات



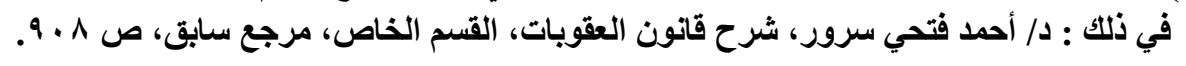

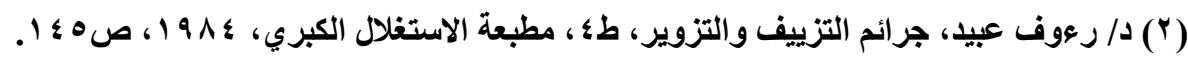


الرسـمية أم لا، ومعرفة مسا إذا كسان الشخص الذي نسب إليـه المحرر يتمتـع بـفة الموظف العـام أم لا، وهذا كله مـ شـأنه أن يعقد العمل نظراً لصعوبة إثبات القـانون الأجنبي وتوزيع عبء الإثبات(')

وعلى الرغم من أن محكمة النقض قد حست أمرها في اعتبار المحرر الأجنبي

الرسـي محرراً عرفيا إلا أن الأمر يظل في إطسار الدراسـة والتقييم لسببين : السبب الأول، يرجع إلى وجاهة مـا تحمله الاتجاهـات الفقهية والقضائية المختلفة من أسـانيا تؤيد الإبقاء أو الإلغاء للصفة الرسمية للمحر الأجنبي الرسمي. والسبب الثاني يتعلق بمدي توافق أحكام النقض مـع السياسة التي ينتهجها المشرع في نصوصه الجنائية. وبناء على ذلك نستطيع أن نقيم الموقف من خلال بيان محل الحماية الجنائية المقصود بنصوص جرائم التزوير في المحررات ، ثم الوقوف علي مدي ضرورة نص المشرع صراحة على رسمية المحرر الأجنبي الرسمي ، وأخيرا كيفية التعامل مع صعوبة إثبات الصفة الرسمية على المحرر الأجنبي الرسمي.

\section{أولاًا : همل الحماية الجنائية المقصود بجرائم التروير في المررات :}

إن المصلحة المراد حمايتها بنصوص جرائم التزوير في المحررات هي الثقة

التي أراد المشرع أن يعطيها له وعدم النيل من قيمتها وحجيتها وإلا تحقق ضرر حتمي بالمـصلحة العامـة(؟). وأسـاس الثقـة العامـة يختلف في المحررات الرسـمية عنـه في

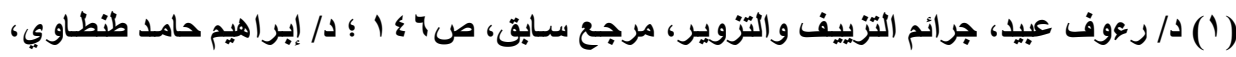

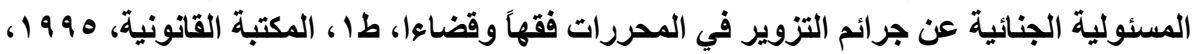

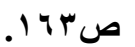

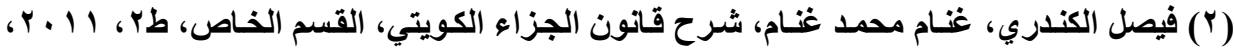


المحررات العرفية، ففي المحررات الرسمية نجد أن أساس الثقة العامـة يأتي من خلال إظهار سلطة الدولة على المحرر من خلال من يمثلها من الموظفين العموميين، بينمـا أساسها في المحررات العرفية يـأتي من خلال إظهار إرادات الأفراد على المحرر كمـا اتفقوا عليها. بمعنى أن الثقة التي أعطتها السلطة الأجنبية لمحرراتها الرسمية ليس مـن شـأنها أن تحمـل ذات الـوزن أو القيمـة في الإقلّيم الـوطني، إلا إذا تــلت عليها السلطة الوطنية بالاعتماد من خلال موظفيها، وبمفهوم المخالفة فإن عدم تلخل موظفي الإقليم الوطني بالاعتمـاد من شـأنه أن يرفع الصفة الرسمية عن المحرر فلا يعدو أن

$$
\text { يكون إلا محرراً عرفياً. }
$$

ولا منــاص مـن القـول بمنطقيـة التوجـه القضائي باعتبـار أن الصفة الرسـمية

للمحررات مرهونـة بتــلـل السلطة الوطنيـة، خـصوصاً وأن الواقـع العلـي يقـرر أن التعامـل مـع المحررات الأجنبيـة الرسمية هو ذاتـه التعامـل مـع أي محرر عرفي مـالم يتلخل عليه موظف عام يمثل السلطة الوطنية.

\section{ثانيًا : صراحة النص التشريعي على رسمية المصرر الأجنبي الرسمي:}

يعزي ن الاتجـاه القضائي الرامسي لرفع الصفة الرسمية عن المحرر الأجنبي الرســي في سـكوت المـشرع عن تحديــ مـا إذا كانـت نـصوص جـرائم التزويـر فـي المحررات تتعلق بـالمحرر الوطني أو المحرر الأجنبي، على أثر أن المشرع لـو أراد للمحرر الأجنبي الرسمي قيمة المحرر الوطني الرسمي لنص على ذلك صراحة. ولا شك أن تفسير مسار المشرع المصري في التعامل مـع المحررات المزورة على هذا النحو يرجع لسياسته في نصوص تجريمـة أخرى، والتي نجد فيها أنـه عبر 
بشكل صريح عن الصفة الأجنبية عندما أرادها كعنصر في بناء الركن المفترض في

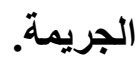

\section{ثالثًاً : إثبات الصفة الرسمية للمصرر الأجنبي الرسمي :}

لعل من أهم الأسباب التي تـدعم مـا أثـاره أصحاب الاتجـاه المؤيـ لرفع الصفة الرسمية عن المحرر الأجنبي الرسمي والمتعلق بصعوبة اللجوء إلى القانون الأجنبي وإثباته، الأمـر الذي يشكل عبئًا على القضاء في التحقق عمـا إذا كـان المحرر يعتبر رسمياً أو عرفياً أو ما إذا كان الموظف الذي تدخل على المحرر أو نسبت إليهه موظفًا عاماً أو لا.

وعلى الـرغم مـن الوجاهـة التـي يظهرهـا هذا السبب الأول إلا أن قبولـه يبدو صـباً، ومـرد تلكك الصعوبة إلى أمـرين : الأمـر الأول، إن البحث القضائي عن مـدي رسمية المحرر في القانون الأجنبي تعتبر من المسائل المتعلقة بموضوع الحق المعتدي عليه في جريمة التزوير(') فالصفة الرسمية للمحرر تمثل - إلى جاتب وجود المحرر والعبث في بياناته الجوهرية ـ شرطاً مفترضاً للتجريم فلا يمكن إثبات الركن المادي في جريمة التزوير إلا بعد ثبوت تلك المسائل والتحقق من انصراف على الجـاني وإرادته

لها، وبناء على ذلك يكون البحث القضائي عنها أمراً منطقياً وإن كلف جهاً إضافياً. والأمر الثاني : إن تطبيق قواعد قانون العقوبات تفرض أحياناً أن يقوم القاضي بالبحث في القـانون الأجنبي أو الوقائع التي تحدث خـارج حدود الإقليم، ولو سـلمنا

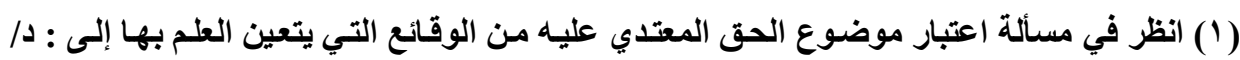

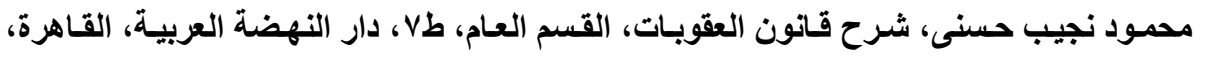


بصعوبة ذلك، لما تمكنا من إعمال تلك القواعد، فنجد على سبيل المثال قاعدة الامتداد الإقليمسي لقـانون العقوبـات التـي تقرر سـريان أحكـام قـانون العقوبـات على الأفعـال الإجرامية التي ارتكبها من يحمل الجنسية المصرية شريطة أن يكون فعله مجرم في الإقليم الأجنبي والإقليم الوطني وعاد إلى مصر دون أن تكون المحاكم الأجنبية قد برأه مما أسند إليه. فالاختصاص ينعقد للقضاء المصري فيمـا يتعلق بـالجرائم التي ترتكب بكاملها على الإقليم الأجنبي إذا كان محلها مالاً عامـاً استناداً لمبدأ العينية. وعلى الرغم من الصعوبة العملية التي تواجـه القاضسي إلا أن ذلك لا يمنعه من القيام بمهامه، وعليه يمكن القول أن هذه الصعوبة لا تقل عن صعوبة البحث فيمـا إذا كـان المحرر الأجنبي يتمتع بالصفة الرسمية أم لا وفقا للقانون الأجنبي، بل قد تزيـا عليها، الأمر الأي يسمح للقاضي أن يتحرى عن مدي توافر الصفة الرسمية للمحرر الأجنبي وعد التعامل معه على أنه محرر عرفي دائماً. فالتحول في الموقف القضائي من الاعتراف بالصفة الرسمية للمحرر الأجنبي الرسمي إلى رفع تلكك الصفة عنه، لم يكن مسلكا غريباً، ذلك أنها تحول من موقف يجد لله تأييدا فقهياً وقضائياً إلى موقف آخر يجد له تأيبداً فقهياً وقضائياً. كما أن رفع الصفة الرسمية عن المحرر الأجنبي الرسمي فيه توافق أكبر مع المصلحة التي يريـ المشرع حمايتها من وراء تجريم التزوير في المحررات الرسمية، خصوصاً إذا علمنـا أن منـاط الثقة المراد حمايتها في المحرر الرسمي تأتي من السلطة الوطنية المعبرة عن إرادة

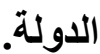

وعلى الرغم من سلامة رفع الصفة الرسمية عن المحرر الأجنبي الرسمي إلا أنه من غير المناسب أن يدعم هذا التوجه بحجة الصعوبة العملية التي يواجهها القضاء 
في التعامل مـع القـانون الأجنبـي، لأن السياسة التشريعية الجنائيـة تفرض في مواقع أخرى في قانون العقوبات حتمية التعامل مع القانون الأجنبي أو الوقائع التي تقع خارج الإقليم استناداً لمبادئ أساسية، كمبدأ الشخصية الإيجابية الذي يفرض الامتداد الإقليمي لقانون العقوبات خارج حدود الدولة، ومبدأ العينية الذي يفرض تتبع الأموال العامـة للاولة خارج الإقليم. فبإذا كـان المحرر الأجنبـي الرسمي معترفـا بـه مـن قبل الاولـة المصرية تعين معاملتـه معاملــة المحـررات الرسـمية الوطنيـة فـي بـاب التزويـر كالشهـادات العلميـة الأجنبيـة والأحكام الأجنبيـة. أمسا إذا لـم يكن معترفـا بـه مـن قبـل الاولـة المصرية فـان التزوير الواقع في محرر رسمي أجنبي يعامل معاملة المحررات العرفية. 


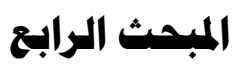

الأهمام الجنائية الأجنبية في القانون الأهريكي

\section{المطلب الأول}

\section{ضهانات استخدام أحكام الإدانة في الحماكمات الجنائية الأهريكية}

ارتفع عدد الأمريكيين الذين أدينـوا في جرائم جنائيسة أجنبية في السنوات

الأخيرة مع زيادة تواجد أعداد من الأمريكيين في دول أجنبية، ونتيجة لذللك؛ واجهت

المحاكم الأمريكية حالات كثيرة سعت فيها النيابة العامـة لتقديم أحكام الإدانة السابقة

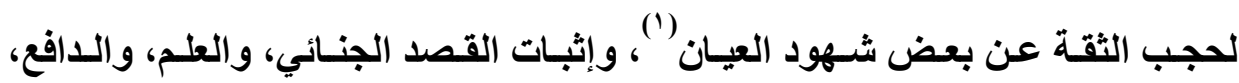

(1) (1) ومن هذه القضايا علي سبيل المثال:

United States v. Wilson, 556 F.2d 1177 (4th Cir. 1977). Formerly, convicted felons were completely barred from testifying; they were treated as incompetents. See MCCORMICK'S HANDBOOK OF THE LAW OF EVIDENCE ? 64 (2d ed. E. Cleary gen. ed. 1972) [hereinafter cited as MCCORMICKJ. During the nineteenth century, state courts were divided over whether a conviction from a sister state rendered a witness incompetent. See, e.g., J. STORY, COMMEN- TARIES ON THE CONFLICT OF LAWS ? 92 (8th ed. 1883); J. WIGMORE, A TREATISE ON THE ANGLO- AMERICAN SYSTEM OF EVIDENCE IN TRIALS AT COMMON LAW? 522, at 615 n.3 (3d ed. 1940). Compare Commonwealth v. Green, 17 Mass. 515, 540-41 (1822) (witness competent) with State v. Candler, 10 N.C. (3 Hawks) 393, 399 (1824) (witness incompetent). 
والتماثٔل في ارتكـاب الجريمـة' ') أو لتقلـيظ العقوبـة على الجـاني بموجب القوانين


كاتت تتجاوب مع هذه الإدانات ، وغالبا ما تقبلها دون فحص دقيق للسياقات الإقليمية التي نشأت في ضوئها.

ويثير الاستخدام غير المتبصر لضمانات الأحكام الأجنبية إثكاليات دستورية

خطيرة، ففي قضية (Burgett v. Texas) (") ق قررت المحكمة العليـا الأمريكية أن الدولـة انتهكت الإجراءات القانونيـة عندما استخدمت إدانـات سـابقة لتظليظ العقوبـة بموجب قـانون العود، حيث استبعدت شـهادة بعض الشهود وفَّـا لهذهـ الإدانـات بمـا

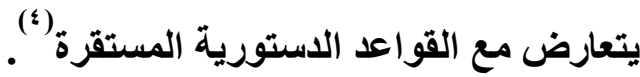
(1) ومن هذه القضايا علي سبيل المثال:

United States v. Ogle, 587 F.2d 938, 940 (8th Cir. 1978) (per curiam) (used to establish identity); United States v. Nolan, 551 F.2d 266, 270-71 (10th Cir.) (used to establish intent and knowledge), cert. denied, 434 U.S. 904 (1977).

(r) ومن هذه القضايا علي سبيل المثال:

United States ex rel. Read v. Martin, 263 F.2d 606, 606 (2d Cir. 1959) (per curiam); United States ex rel. Foreman v. Fay, 184 F. Supp. 535, 536-37 (S.D.N.Y. 1960); United States ex rel. Dennis v. Murphy, 184 F. Supp. 384, 385 (N.D.N.Y. 1959); People v. d'A Philippo, 220 Cal. 620, 624-25, 32 P.2d 962, 964 (1934) (en banc); State v. O'Day, 191 La. 380, 387-88, 185 So. 290, 292 (1938); People ex rel. Latraverse v. Jackson, 284 A.D. 822, 822, 132 N.Y.S.2d 115, 116 (1954) (mem.); People ex rel. Stevens v. Jackson, 283 A.D. 3, 5, 125 N.Y.S.2d 905, 907 (1953).

(3) 389 U.S. 109 (1967).

(4) Loper v. Beto, 405 U.S. 473 (1972) ; United States v. Tucker, 404 U.S. 443 (1972). 
وكانت بعض المحاكم الأدنى قد نظرت إلى نفس القضية "Burgett" مع حظر

الاعتماد على الإدانات السابقة التي تم الحصول عليها بشكل غير مبرر، على أسـاس أن

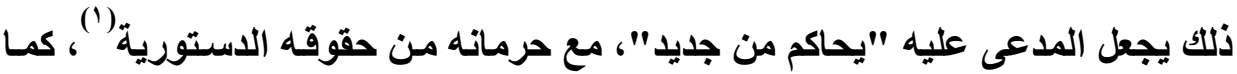
وردت بعض الممارسـات الخاصـة بعدم إمكان الاعتمـاد على الإدانـات السابقة التي تم

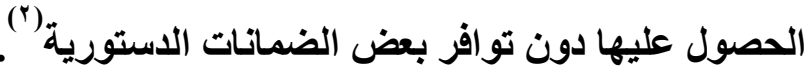
هذه المخـاوف التـي تكتنف اسـتخدام ضـمانات الإدانـات المحلية تصبح أكثر تعقيدًا في حالات أحكام الإدانة الأجنبية، التي نادرًا مـا تتوافق مـع المعايير الاستورية، ومـع استقراء حكم قضية "Burgett" باعتباره يتطلب توافق الإدانـات السابقة مـع القواعد الاستورية، فِإن المحاكم الأمريكية ستمنع استخدام أو الاعتمـاد على جميع . الأحكام الأجنبية أمامها. وحتى لو استخدم حكم Burgett فقط بغرض حمايـة المدعى عليه من استخدام إدانات غير موثوق بها ضده، فإن ذلك يثير عقبات عملية خطيرة ضد الاستخدام الناجح لأحكام الإدانة الأجنبية. ويجب التشديد على توافر المصداقية والثقة كمعيار أساسي لتحديد استخدام الضمانات المسموح بهـا مـن الإدانـات الخارجيـة، واسـتبعاد أي حكم أجنبـي يتضمن إجراءات غير مألوفة لا تفي بهذا المعيار، ويتطلب ذلك وجود قيود صسارمة للإجراءات

(1) The "suffer anew" language was used by the Supreme Court in Burgett, 389 U.S. at 115. For an example of a lower court applying similar reasoning, see Beto v. Stacks, 408 F.2d 313 (5th Cir. 1969).

(2) See, e.g., United States v. Penta, 475 F.2d 92, 96 (1st Cir.) (Aldrich, J., concurring), cert. denied, 414 U.S. 870 (1973).




المعتمدة بشأن الإشراف على هذا استخدام هذه الضمانات، مـع اقتراح وجود مخطط إجرائي لفحص الإدانات الأجنبية المحتمل إثارتها أمام المحاكم الأمريكية. أولاً: التأصيل الدستوري لقضية (Burgett v. Texas): في هذه القضية تم توجيه تهمة أساسية للمدعى عليه، وهي الاعتداء بقصد القتل، وكذلك أربع تهم بموجب قانون "العود" لولايـة "تكساس"، والتي تجسدت في

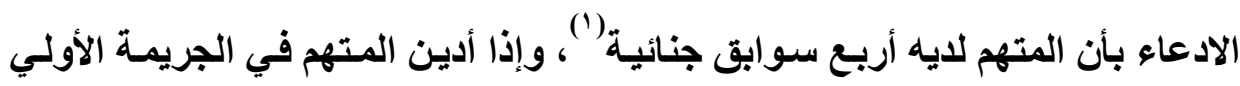
فِإن العقوبـة المقررة لها هـي "السجن مدى الحيـاة؛ إذا ثبتـت صحة التهمـة الخاصـة بالعود، وهي التهمة التي قدمت النيابـة العامـة أدلـة عليها، تتجسد في إدانـات وأحكام سابقة على المتهم، تم الحكم في إحداها على المتهم دون تأمين وجود محامي للدفاع عنه ") وبالتالي شاب هذه الإدانة بطلانًَا بموجب حكم سـابق للحكمة العليا في قضية (Gideon v. Wainwright) ضد المدعى عليه كانت إمـا "للدعم الإدانـة أو تغليظ العقوبـة على جريمـة أخرى، وقد رأت المحكمة في قضية " Burgett" أن الإدانة السابقة قد شابها مخالفة متمثلة في "الحرمان من الحق في الاستعانة بمحام" مما يحرم المتهم من حق التعديل الدستوري السادس، وبالتالي يمثل الأخذ بهذه الإدانة خطأ دستوري.

(1) 389 U.S. at 111.

(2) Loper v. Beto, 405 U.S. 473, 485 (1972) (White, J., concurring in result), it remains unresolved.

(3) 372 U.S. 335 (1963). See Burgett, 389 U.S. at 114. 


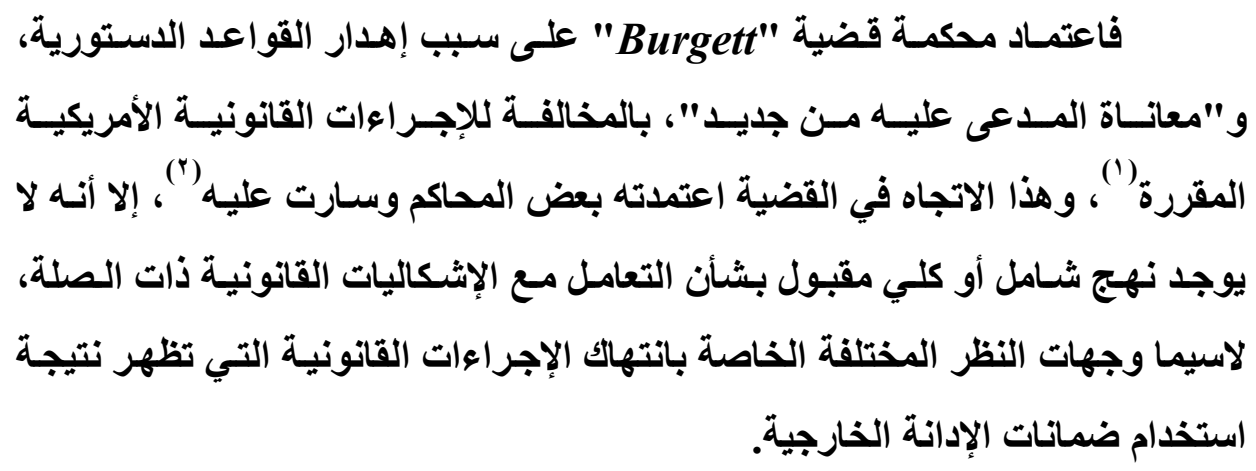

(1) Unless a foreign court can be shown to have acted as an American agent, it is a creature of a foreign sovereign and is not subject to constitutional constraints. See, e.g., In re Ross, 140 U.S. 453, 464 (1891); United States v. Toscanino, 500 F.2d 267, 280 n.9 (2d Cir. 1974); Brennan v. University of Kan., 451 F.2d 1287, 1289-90 (10th Cir. 1971); Birdsell v. United States, 346 F.2d 775, 783 (5th Cir.), cert. denied, 382 U.S. 963 (1965). To be sure, the Constitution does accompany the American government abroad. See Reid v. Covert, 354 U.S. 1, 5-6 (1957). An incidental presence, however, is usually insufficient to result in application of the Constitution if the acts in question are primarily those of a foreign sovereign.

(2) Beto v. Stacks, 408 F.2d 313, 316-17 (5th Cir. 1969). In United States ex rel. LaNear v. LaVallee, 306 F.2d 417 (2d Cir. 1962), a habeas corpus decision antedating Burgett, the Second Circuit considered the collateral use of an uncounselled Missouri conviction in New York. Responding to New York's contention that its use of the Missouri conviction did not render it responsible for the Missouri procedure, Judge Friendly held that the violation of due process was by New York, not Missouri. Id. at 420. He relied for this result on two earlier habeas corpus cases, United States ex rel. Dennis v. Murphy, 265 F.2d 57 (2d Cir. 1959). 
ولعل أحد التوصيفات المألوفة بشأن استخدام أحكام الإدانة الأجنبية، أن تثثبت

وتتأكد المحكمة المحليـة مـن الإجراءات الأجنبيـة مـن تلقـاء نفسها ووفةَّا لقناعاتهـا، وبالتالي تكون كل الإجراءات القانونيـة المحلية والأجنبية خاضعة للتدقيق. اتجـاه آخر للتعامل مع هذه الأحكام يتمثل في الإدانة المسبقة لاي بعض المحسكم بـأن أحكام الإدانـة الأجنبية معيبة وباطلة (') وبالتالي فسادها كضمانات للاستدلال، وما تجدر الإشارة إليه بشان الاتجاهين السالفين، أنه طالما كـان الاستور الأميركي لا ينطبق على الإجراءات القانونية الخاصة بالدول الأجنبية، فلا يمكن إبطال هذه الأحكام الأجنبية بموجبه وتبقى صـحيحة فيمـا يتعلق بعلاقتهـا بالقـانون الأمريكي، ومـن هـــانلاحظ أن كـلا الاتجـاهين يتصف بالنظرية المفرطة ويمكن اعتبار هما من قبيل الحيلة القانونية. وبصرف النظر عن غموض التحليلات بشأن استخدم ما قررته المحكمة العليا في قضية "Burgett"، فلا يمكن إخضاع الإجراءات الأجنبية الأصلية لتدقيق صسارم وغير مرن لمجرد أن بعض المحاكم المحلية لديها قناعات أو شعور بعدم اعتمـاد سلوك خارجي بوجه عام، أو ضمانات قد تتعارض مـع نظريـات سـائدة تم الاعتمـاد عليها في أحكام سـابقة، وعلى سبيل المثال، تم انتهاك تطبيق قاعدة الاستثناء على الأدلة من قبل المسئولين الأجانب في انتهاك للتعديلات الرابعة والخامسة () ، ولعل استبعاد مثل هذه

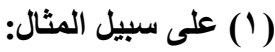

United States v. Martinez, 413 F.2d 61 (7th Cir. 1969) (dictum).

(2) Commonwealth v. Wallace, 356 Mass. 92, 248 N.E.2d 246 (1969). The level of involvement typically necessary to be characterized as government involvement calling for application of the Constitution is quite high 


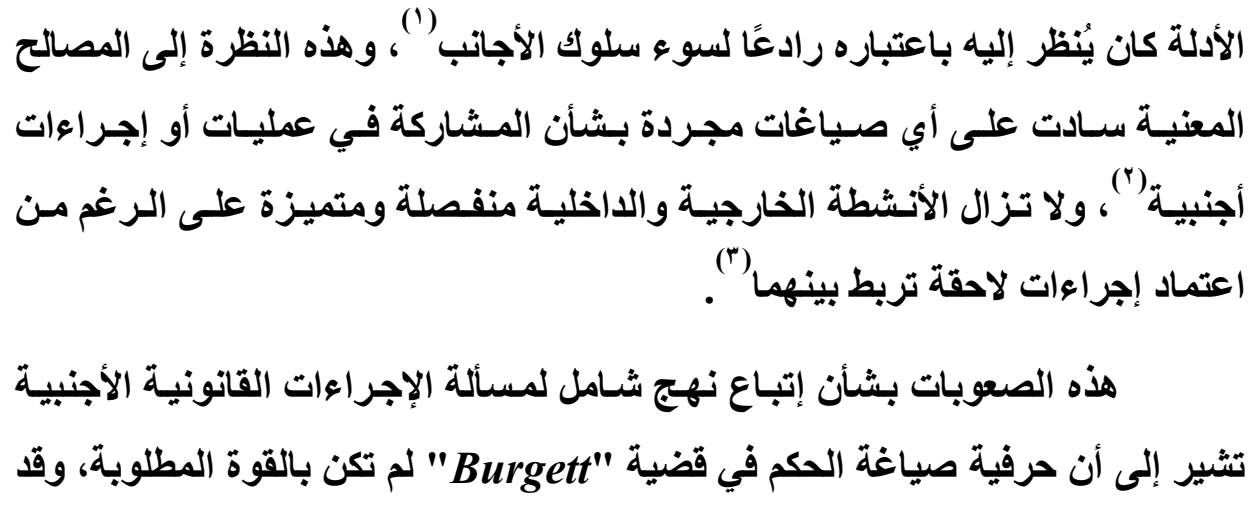

(1) Commonwealth v. Wallace, 356 Mass. 92, 248 N.E.2d 246 (1969). Deterrence fails only if American agents are not involved

(2) United States v. Cotroni, 527 F.2d 708, 711-12 (2d Cir. 1975), cert. denied, 426 U.S. 906 (1976); Commonwealth v. Wallace, 356 Mass. 92, 95, 248 N.E.2d 246, 247-48 (1969). See generally 1 W. LAFAVE, supra note 24, ? 1.6(g). See also id. ? 1.7(a); Comment, Jurisdiction Following Illegal Extraterritorial Seizure: International Human Rights Obligations as an Alternative to Constitutional Stalemate, 54 TEX. L. REV. 1439 (1976)

(3) The principle that foreign and domestic proceedings are separate and distinct also seems to underlie Neely v. Henkel, 180 U.S. 109 (1901). In Neely, the Supreme Court rejected a challenge to an extradition act that the act failed to ensure that the accused's constitutional rights would be secure in the foreign tribunal. While examination of a sister state's tribunal is impermissible, see Michigan v. Doran, 439 U.S. 282 (1978), the Second Circuit has recently expressed a willingness to examine foreign process in particularly compelling cases, see, e.g., United States ex rel. Bloomfield v. Gengler, 507 F.2d 925, 928 (2d Cir. 1974); Gallina v. Fraser, 278 F.2d 77, 79 (2d Cir.) (dictum), cert. denied, 364 U.S. 851 (1960). 
تخفي مصالح معينة، وربمـا كـان مـن الأفضل ان تتأسس القضية على عدم إمكانيـة

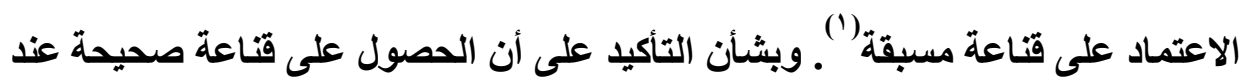
استخدام الأحكام الأجنبية يجنب المتهم مـن المعانـاة من جديد؛ ربطت المحكمة قرارهـا مباشـرة بـأن ذلك نـوع مـن انتهـاك الاسـتور والقواعد المتعلقة بـالحق في الاستعانة بمحام ') ومنذ أن تم إقرار مبدأ قضية "Gideon v. Wainwright" والمتعلق بـأن وجود محامي في الاعوى جوهري لحكم جدير بالثقة؛ فإنه يجوز للمحكمة أن تُشير إلى قلقها، ليس مع استخدام إدانة مسبقة معيبة في حد ذاتها، ولكن مع استخدام إدانة ترتكز على إجراعات غير شفافة تشكك مصداقية الحكم. والاستخدام العرضي أو الثانوي لمثل هذه الإدانة يقود المحاكمة الثانية التي قد تعول علي تلكك الإدانـة لخطر الاعتمـاد على إنى إدانة زائفة ربمـا نتجت عن انتهاك إجراعات قانونيـة واجبة، وبالتالي، يعاني المدعى

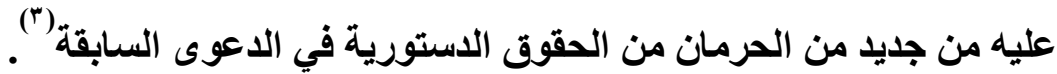
ويمكنــا ملاحظة أن نظرة المحكمة في حكم "Burgett" تركز على طـابع الإدانة المعية ودورها في الدعوى الثانية، بلاًا من التركيز على مجرد وجود خلل في المقام الأول، وهو نهج "مُجزأ" فيما يتعلق بإثكالية تنفيذ الأحكام الأجنبية، حيث يتم التعامل مع نفس الإجراءات بشكل تمييزي، مـع الاعتر اف بـأن للإجراء السابق تأثير على قضية لاحقة، كمـا أنها تتوجه نحو النتائج الصحيحة أكثر من التثبت من صحة

(1) Lewis v. United States, 48 U.S.L.W. 4205, 4208 (U.S. Feb. 27, 1980) (No. 78-1595) .

(2) Burgett, 389 U.S. at 115.

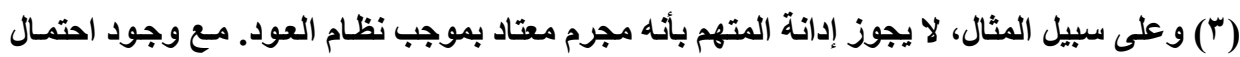
بأنه بريء، وان إدانته ريما جاءت نتيجة استخدام قناعة زائفة سابقة.

1. مجلتّ البحوث القانونيت والإقتصاديت 
الإجراءات، وهذا النهج ينظر بشكل جوهري إلى السياسات والمصالح الكامنـة وراء الحماية الدستورية لتحديد مـا إذا كـان غيـاب هذه الحمايـة قد يُشوه مخرجـات القضية الثانية. في نهاية المطاف، فإنه يميز بين فئتين من العيوب: تلك التي تهدد مصداقية الإجراءات القضائية، وتتلك التي تعكس المفـاهيم الأمريكية حول العلاقة الصحيحة بين المـواطن والدولـة. كمـا يظهر من خـلال الجزء التـالي، فهذه الفئة الأخيرة التي تمثنل انتهاكـات جماعيـة ويمكن أن نشير إليها باسـم "العنصر السياسي للعدالة" ـ ليست ضـالعة إلى حد كبير في الحسالات التي تنطوي على محاكمـة مـواطن أمريكي في بلـا

\section{ثانياً: العنصر السياسي للهدالة:}

في الفقهـ الأمريكي الحديث، يتضمن ضـمان المحاكمـة العادلة مفهوم العدالـة

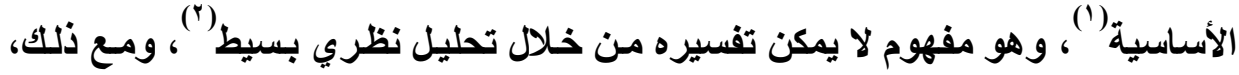
فِإن الطريقة التـي بموجبها طبقت المحكمـة العليـا مبدأ المشروعية على الإجراءات الجنائية في السنوات الأخيرة والقرارات الصادرة بناءً على ذلك، تثير إلى وجود تمبيز

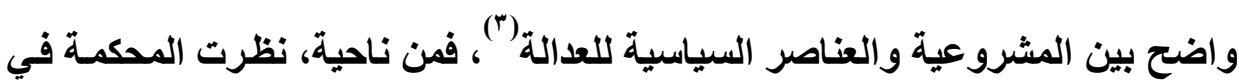

(1) TRIBE, AMERICAN CONSTITUTIONAL LAW ? 10-8, at 506-07 (1978).

(2) Kadish, Methodology and Criteria in Due Process Adjudication-A Survey and Criticism, 66 YALE L.J. 319 (1957).

(3) Eskridge v. Washington Bd. of Prison Terms \& Paroles, 357 U.S. 214 (1958) (per curiam) (extending Griffin v. Illinois, 351 U.S. 12 (1956)); United States v. Peltier, 422 U.S. 531 (1975) (refusing to extend AlmeidaSanchez v. United States, 413 U.S. 266 (1973)); Johnson v. New Jersey, $=$

مجلت البحوث القانونيتي والإقتصاديت 
دستورية عيوب الإجراءات الجنائية التي تنـال من دقة عملية تقصي الحقيقة، والتي تزيل من خطر إدانة شخص بريء "'، مثل هذه العيوب التي تؤثر على جوهر العملية

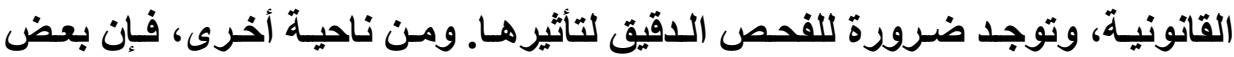
العيوب في الإجراعات الجنائيـة مهمـة في المقـام الأول مـن وجهـة نظر العلاقـة ببين الحكومة ومواطنيها، كالقيود المفروضة على التفتيش والضبط مثل تلك التي لا تتصل مباشرة بعملية تقصي الحقيقة، ولكنها تمثل قرارات مؤثرة على العلاقة بين الدولة

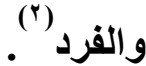

وعند النظر في الاستخدام المسموح بـه للإدانـات والأحكام الأجنبية، نجد أن المحاكم الأميركية قد أولت مزيدًا من الاهتمام لعنصر المشروعية أو الدقة وصحة الدكم بدلاً من التركيز على العنصر السياسي للعدالة، ومنذ ظهرت مسألة الإدانـات المسبقة التي يمكن أن تلعب دورًا مهمًا في الإدانـة، والحكم على المتهم، وكذلك قواعد الإثبات التي تمنع عـادةً الرقابـة الصارمة والفعلية على الحقائق الكامنـة وراءهـا، فِإن الإدانـة

384 U.S. 719 (1966) (refusing to extend Miranda v. Arizona, 384 U.S. 436 (1966) and Escobedo v. Illinois, 378 U.S. 478 (1964)); Linkletter v. Walker, 381 U.S. 618 (1965) (refusing to extend Mapp v. Ohio, 367 U.S. 643 (1961)).; Smith v. Spina, 477 F.2d 1140, 1147-48 (3d Cir. 1973); United States v. Penta, 475 F.2d 92 (Ist Cir.), cert. denied, 414 U.S. 870 (1973); State v. Murray, 86 Wash. 2d 165, 167, 543 P.2d 332, 334-35 (1975) (en banc). But see Beto v. Stacks, 408 F.2d 313 (5th Cir. 1969).

(1) Williams v. United States, 401 U.S. 646, 653 (1971); Linkletterv. Walker, 381 U.S. 618, 638-39 (1965

(2) Addington v. Texas, 441 U.S. 418 (1979); Underwood, The Thumb on the Scales of Justice: Burdens of Persuasion in Criminal Cases, 86 YALE L.J. 1299, 1307-08 (1977) 


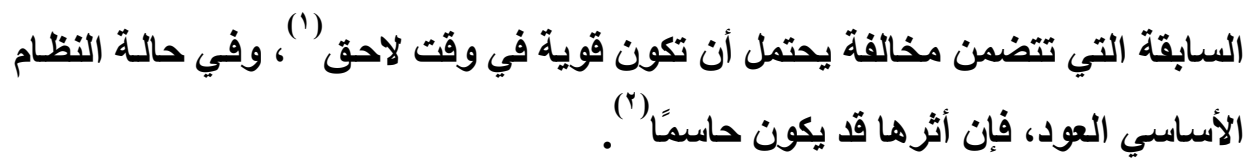

ونلاحظ أن الإجراءات الأجنبية ربما لا تلبي العنصر السياسي للعدالة، ولا تعير

المحاكم لذلك أهميـة كبيرة، ومجـال تطبيق الاستور يقتصر على الحدود الوطنيـة، ولا

يحكم العلاقات السياسية في الخـارج، ومن العبث أن تسعى النيابة العامـة عند تطبيق

(1) Loper v. Beto, 405 U.S. 473 (1972), a case involving the collateral use of a domestic conviction. In Loper, the defendant charged with rape had taken the stand as the sole witness in his own defense. During crossexamination, the defendant "admitted in damaging detail," id. at 474, to four prior felony convictions, all of which had allegedly been obtained at proceedings in which the defendant had been denied his right to counsel. The defendant was convicted. Given the distorting effect the earlier Gideon violations might have had on the reliability of the rape conviction, the Supreme Court set aside the judgment of the court of appeals denying the defendant a writ of habeas corpus and remanded for further proceedings.

(2) R. SINGER, JUST DESERTS: SENTENCING BASED ON EQUALITY AND DESERT 67-74 (1979). The first is that the repeat offender is more blameworthy since he had notice through his prior conviction of the serious- ness of the criminal law. Id. at 68 . The second is a variant of the first, and relies upon an analogy to the treatment of juveniles: a first offender, like a juvenile, is less blameworthy since he does not appreciate the full import of his behavior. Id. at 71. Under either variation, the use of an unreliable prior conviction to enhance punishment under a recidivist statute remains proper. If the concern of recidivist statutes is merely the naivete of the accused, then a prior conviction, whether or not reliable, is evidence of the accused's familiarity with and appreciation of the seriousness of criminal conduct. 
الإدانـات الأجنبيـة إلى استخدامها لغرض ضمانات ترضسي العنصر السياسي للعدالـة، والمثال على ذلك يتجسد في الإدانة الأجنبية بناءً على الأدلة التي تم استبعادها لأسباب

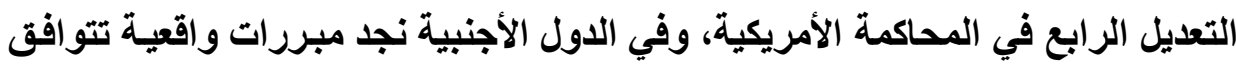
مع مصلحة الدول ومجتمعاتها في إدانة ومعاقبة المدعى عليه وفقًا للعدالة السارية، أمسا الاسـتخدام اللاحق لأحكـام الإدانـة الأجنبيـة فيتم إبلائهـا اهتمـام أقل مـن قبـل المحساكم

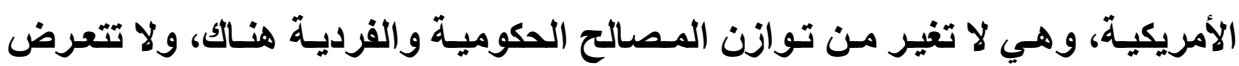
للعلاقة بين المواطن والدولة في الولايات المتحدة. وعلاوة على ذلتك، السياسة الأولية التـي تقوم عليهـا أي اسـتثناءات على هدف الـردع، كالاسـتثناءات على الانتهاكـات الاستورية، لن يتم تعزيزها باستبعاد الحكم الأجنبي، أو من خلال تطبيق القاعدة على الإدانات الخارجية، حتى مع احتفاظ المحكمة الأمريكية بالسلطة الكاملة لمواجهة انتهاك قوانينها، والسلطات الأمريكية التي تتحمل آثار قاعدة الاستثناء، وهاتان الجهتان تقفـان عاجزتين عن تغيير الممارسات الأجنبية، ويكون تطبيق هذه القاعدة رمزيًا '(')

(1) American courts routinely reject challenges to the introduction of evidence that was acquired through foreign police misconduct. See, e.g., United States v. Mundt, 508 F.2d 904 (10th Cir. 1974), cert. denied, 421 U.S. 949 (1975); Kilday v. United States, 481 F.2d 655 (5th Cir. 1973); United States v. Welch, 455 F.2d 211 (2d Cir. 1972) (per curiam); United States v. Chavarria, 443 F.2d 904 (9th Cir. 1971) (per curiam); Birdsell v. United States, 346 F.2d 775, 782-83 (5th Cir.), cert. denied, 382 U.S. 963 (1965); People v. Helfend, 1 Cal. App. 3d 873, 82 Cal. Rptr. 295 (1969), cert. denied, 398 U.S. 967 (1970); Commonwealth v. Wallace, 356 Mass. 92, 248 N.E.2d 246 (1969). The application of the exclusionary rule by American courts to foreign police misconduct would be merely symbolic in the sense that the deterrence aim of the exclusionary rule would not be served. 
عندما تستخدم ضمانات من الإدانـات الأجنبية لا تتفق مـع العنصر السياسي

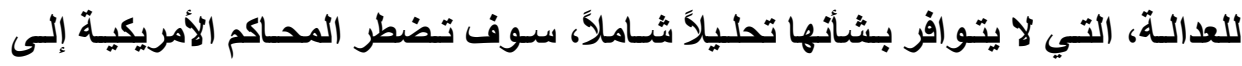
استبعاد الأدلة المحتمل ألا تتوافق مـع الدستور دون التأثير على توازن العلاقات بين المواطن والدولة المنصوص عليها في الاستور. من ناحية أخرى، استخدام المحكمة لنهج مجزأ، عن طريق فصل الإجراءات الأجنبية والمحلية، يخلق فرصـة لتقييم كفـاءة العمليـة القانونيـة مـن خـلال تبين الأثر الفعلي لهذه الإدانـة الخارجيـة على إجراءات القضايا اللاحقة.

وأمام استخدام الأطر المجزأة في التدقيق في الاستخدام العرضسي للضمانات

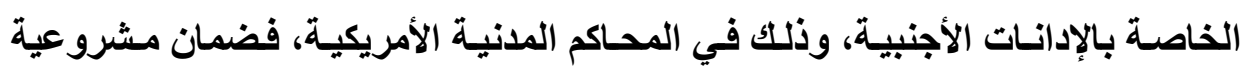
الأحكام تظل هدف كل أنظمة العدالة البديلة أو المكملة للجنائية، ولكنها لا تكترث بشدة أو توظف كافة الإجراءات التي تتضمن العنصر السباسي للعدالة' ') وعلى سبيل المثال الإجراعات القانونية العسكرية، لا توفر مثل هذه الحماية المدنية الأساسية كتلك التي

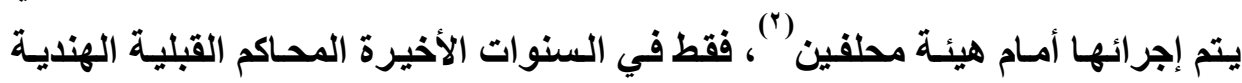

(1) Military due process is not coextensive with civilian due process since the former derives from the specific task of maintaining discipline and order in the Armed Services. See United States ex rel. Toth v. Quarles, 350 U.S. 11, 17 (1955); Burns v. Wilson, 346 U.S. 137, 140 (1953); id. at 149 (separate opinion of Frankfurter, J.). But see Comment, Investigative Procedures in the Military: A Search for Absolutes, 53 CALIF. L. REV. 878 (1965).

(2) See Whelchel v. McDonald, 340 U.S. 122, 127 (1950); U.S. CONST. amend. $V$. In some military proceedings, such as the summary courtmartial, defense counsel may be denied. See Middendorf v. Henry, 425 U.S. 25 (1976); Comment, The Summary Court-Martial in Constitutional Perspective, 14 Hous. L. REV. 449 (1977). The summary $=$ 


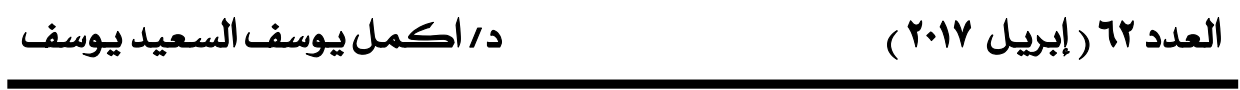

توفر حماية إجرائية أكثر من الحماية الإجرائية الأمريكية المتعـارف عليها (') وربمـا

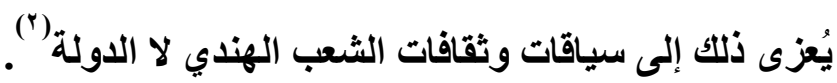

court-martial is a frequently employed proceeding. See 2 U.S. DEP'T OF DEFENSE, REPORT OF THE TASK FORCE ON THE ADMINISTRATION OF MILITARY JUSTICE IN THE ARMED FORCES 47 (1972) (of total courts-martial in fiscal year 1972, over 23,000 , or $43.8 \%$, were summary). Even more striking than summary courts-martial are the nonjudicial disciplinary pro- ceedings sanctioned under article 15 of the Uniform Code of Military Justice, 10 U.S.C. ? 815 (1976). In article 15 actions, the commanding officer who brings the charge is also the sole adjudicator. Article 15 actions are numerous and sometimes involve serious crimes. 3 U.S. DEP'T OF DEFENSE, supra, at 91-113. Moreover, the adjudicative officer has the power to confine an enlisted man to "correctional custody" for up to 30 days. Middendorf v. Henry, 425 U.S. 25, 36 (1976).

(1) Known as the "Indian Bill of Rights," now 25 U.S.C. ? 1302 (1976), the law was enacted as part of the Civil Rights Act of 1968, Pub. L. 90-284, 82 Stat. 77, Titles II to VII deal generally with Indian civil rights, 25 U.S.C. ?? 1301-1341 (1976), while Title II, section 202, is the equivalent of the Bill of Rights, id. ? 1302. Not all rights are guaranteed. The most notable exception is indigents' right to counsel, for as 25 U.S.C. section 1302(6) states: "No Indian tribe . . . shall deny to any person in a criminal proceeding [in tribal court] the right . . . at his own expense to have the assistance of counsel for his defense." 25 U.S.C. ? 1302(6) (1976) (emphasis added). Free counsel for indigents, required in federal and state courts since Gideon v. Wainwright, 372 U.S. 335 (1963), and Argersinger v. Hamlin, 407 U.S. 25 (1972), is not required in tribal courts. See Tom v. Sutton, 533 F.2d 1101, 1104 (9th Cir. 1976

(2) See United States v. Kagama, 118 U.S. 375, 381-82 (1886); Colliflower v. Garland, 342 F.2d 369, 374-75 (9th Cir. 1965). But see Fretz, The Bill of Rights and American Indian Tribal Governments, 6 NAT. $=$ 
وكثيرًا مـا تسمح المحاكم الأميركية باستخدام ضمانات الإدانـات من المحساكم

العكرية والهندية، وهذا الاستخدام يشير إلى أنه حتى الإجراعات الجنائية التي لا تلبي متطلبات العنصر السياسي للعدالة يمكن أن تكون مقبولـة طالمسا أنها تقود إلى نتائج فعلية جديرة بالثقة، وبالتـالي هذه الأنظمـة القضائية المحليـة المختلفـة تثير احتمـال استخدام إدانات النظم القانونية الأجنبية في المحاكم المحلية دون الإسـاءة إلى مفـاهيم العدالة الأساسية، وهذا الاستتناج هو الخط الفاصل بين العنصر السياسي للعدالـة، والمشروعية في الحكم، وربمـا يتضح ذلك من عدم استقرار المحكمة الأميركية على قبول الإدانة التي تم تقريرها من خلال إجراعات تنطوي على انتهاكات جسيمة لمعايير السياسية الأميركية الأساسية، وهذا الأمسر يتعلق بوجود أسـاس لا يمكن بعده قبول انتهاكـات العنـصر السياسي للعدالـة، وهـو مـا يـدعونـا لتحليل تـوافر عنـصر النزاهـة

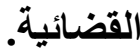
ثالثًا: صدهة للضمير: قبل تمديد قاعدة الاستثناء إلى الدول في قضية (Mapp v. Ohio) (') ،ظرت المحكمة العليا عددًا من الحالات التي تضرر فيها المتهمون من سوء سلوك واضـح من الاولة تجاهم، وكرد فعل لذلك، ظهرت نظريـة فرعية للعنصر السياسي للعدالـة، عُرفت

RESOURCES J. 581, 599 (1966) ("A method of resolution which the courts are barely beginning to explore is the concept of treating the tribe as a state or territory for purposes of applying the due process clause."). (1) 367 U.S. 643 (1961). 
باسم "نزاهة السلطة القضائية" (") والمفهوم الكـامن وراء هذه النظريـة هو أنها من خلال السماح لاستخدام الأدلـة بطريقة تسيء لأعراف وشـعور المجتمع فإن المحكمة تحسول القواعـــ القانونيـة لعبـاءة مـن القـسوة والوحسشية وتـــاقض نزاهـة النظــام القضائي ()، وعلى الرغم من أن هذا الفرع من العنصر السياسي للعدالة وضـع أساسيًا كوسيلة لضمان الحد الأدنى من امتثال الدول للمعايير المعمول بها، والغرض الذي تم تجاوزهـا عن طريـق دمـج أكثر مـن وثيقة العقوق في التعديل الرابـع عشر، وفكرة النزاهـة القضائية ثُفعل الاحتفـاظ ببعض الحيويـة، وتعكس المخـاوف المستمرة بشأن شرعية النظام القضائي الأمريكي. مثل هذه المخاوف حول نزاهة السلطة القضائية تؤدي دورًا مشروعًا في تقييم أحكام الإدانة الأجنبية، حتى لو كاتت حدود تطبيق الاستور، ومنطق نظريـة الإجراءات القانونية تمنع المحكمة من البت في مسائل استخدام الضمانات وفقًا لمطالب محددة من النظام الأمريكي لحمايـة إجراعات التقاضسي، فإنها لا تقضي على الحاجـة إلى إنشاء محكمة للحفاظ على شرعيته، فهناك إدانة أجنبية ناتجة عن ممارسات شرطة أجنبية لا تلتزم بالقانون وتتتهكه، ووفَّا للمعايير الأمريكية يمكن، إذا مـا استخدمت في محكمة محلية، أن تؤثر على شعور الجمهور بعدالة الإجراعات ضد المدعى عليه، حتى لو كـان لا يقوض مصداقية عملية تقصي الحقيقة.

(1) United States v. Calandra, 414 U.S. 338, 355-61 (1974) (Brennan, J., dissent- ing); Rochin v. California, 342 U.S. 165 (1952); Weeks v. United States, 232 U.S. 383, 391-92 (1914). See also Schrock \& Welsh, Up from Calandra: The Exclusionary Rule as a Constitu- tional Requirement, 59 MINN. L. REV. 251 (1974

(2) Rochin v. California, 342 U.S. 165, 173 (1952 
كمـا أن وضـع معسايير قابــة للتطبيـق لهـذا المبـدأ هـي مهمـة صسعبة، حيـ

المششروعية والعلاقـات السياسية بـين الدولـة والمـواطن لا تـــلـل ضـمن المسـألة، والاعتبـارات القائمسة على النزاهـة القضائية تتعـارض مـع مصالح أخرى مـن النظـام

القـانوني الأمريكي، وخاصـة قواعد العقوبة، علاوة على ذلك، إذا قررت المحكمة أن استبعاد أدلة موثوقة يزيلـ من احتمـال تبرئسة المتهم، فبان ذلك قد ينطوي على خطر تقويض ثقـة الجمهور في قدرته على تحقيق العدالـة، وتشير هذه المخـاوف إلى أن نزاهة السلطة القضائية تقتضي استبعاد أدلة الإدانة فقط عندما تكون السياسات التي يقوم عليها تفوق مصلحة الحكومـة في استخدام وتقييم الأدلة بشكل سليم (') وهكذا، على سبيل المثال، يمكن الاعتماد على الإدانة الخارجية باعتبار هـا موتُوقة وئقبل حتى لو كان الحصول عليها تم من خلال بحث ينتهك التعديل الرابع بثأن الاتهام بجريمة قتل

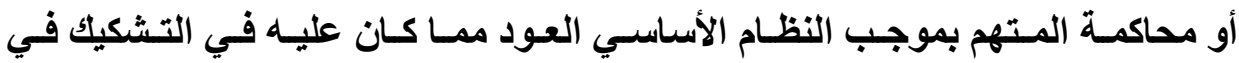

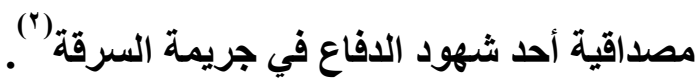

(1) Cf. Stone v. Powell, 428 U.S. 465, 485-86 (1976) ("While courts, of course, must ever be concerned with preserving the integrity of the judicial process, this concern has limited force as a justification for the exclusion of highly probative evidence

(2) This balancing approach is easily reconciled with, and indeed seems implicitly to underlie, the Ker-Frisbie doctrine. Under the doctrine, "a court's power to bring a person to trial upon criminal charges is not impaired by the forcible abduction of the defendant into the jurisdiction." United States v. Lira, 515 F.2d 68, 70 (2d Cir.), cert. denied, 423 U.S. 847 (1975). 


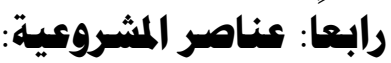

تطبيق نهج مجزأ لتقييم مخـاوف الإجراءات القانونيـة الناشئة عن استخدام

ضـــانات الإدانــات الخارجيـة تتطلب النظـر في مـصداقية تلـك الإدانـات ، والسماح باستخدامها بالرغم من أن الإجراءات المتبعة في الحصول على الإدانـة ليست نفسها



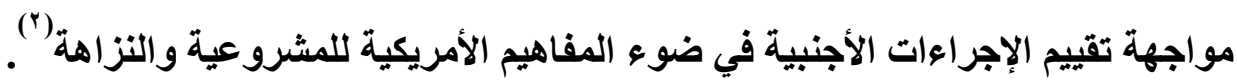
هذا التهج الموجه نتيجة لاستخدام الإدانات الخارجية فرعيـة، يجب أن لا يمثل موافقة على التخلي الكامل عن جميع الإجراعات المألوفة، فعلى الرغم من أن محكمة أجنبية قد تستغني، أو تعثر على بـائل لبعض الجوانب التقنية لنظام العدالة الجنائية الأمريكي دون المساس بنتائجسه، فبإن غيـاب بعض الأساسـيات سيؤدي إلى النتيجـة السابقة، وعلى سبيل المثال، إذا افتقرت الإدانة الخارجية إلى المشروعية المطلوبة فتم الحصول عليها دون حضور المدعى عليه في المحكمة، بمـا في ذلكك إعلامـه في الوقت المناسب بالتهم الموجهة إليه، والتحقيق الرسمي في تلكا التهم، وإعطائه فرصـة لتقديم

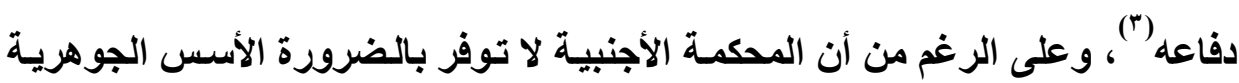
في شكل الخصومة المألوف في المحاكم المحلية، فينبغي دراسـة الإجراءات الخارجية للضمانات و التدقيق للتأكد من نتائجها.

(1) American courts have, in a variety of contexts, accepted foreign process departing significantly from domestic standards. See, e.g., United States v. Wilson, 556 F.2d 1177, 1178 (4th Cir.)

(2) Cf. Johnson v. New Jersey, 384 U.S. 719, 729 (1966)

(3) L. TRIBE, supra note 33, ? 10-8, at 512-13. 


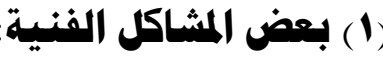

يكون استخدام ضمانات الإدانات الأجنبية معقدًا بسبب الاختلاف بين مـا تعتبره الولايات المتحدة والدول الأجنبية سلوك إجراميًا، وبالتالي يوجد احتمال بنشوب خلافات كبيرة، تتعلق بعناصر الجرائم الأجنبية المختلفة من دولة لأخرى، وقد تنعقد الجريمـة في دولة بينما لا تعد كذلك في الدولـة الأخرى، وبالتـالي، يجب على المحكمة أن تضع معايير للتعامل مع مثل هذه الإشكاليات.

في بعض الحسالات، وعندما تغيـب الموضـوعية لا يتـوافر أسـاستًا كافيًا لمنـع استخدام ضمانات الإدانـة الخارجية، كمـا هو الحـال مثثلاً عندما تُستخدم أحكام الإدانـة الأجنبيـة لاسـتبعاد أحـــ الـشهود، اسـتثناعً مـن الحظـر المفـروض على الأدلـة ذات

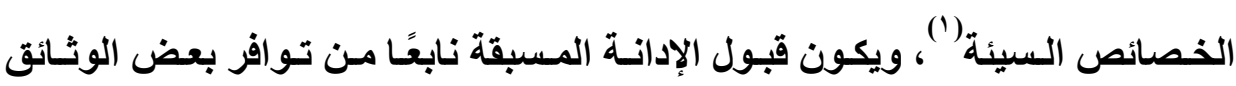
الرسمية التي تثبت أن الفرد كان مرتكبًا لجريمة معينة، ووجود مثل هذه الوثائق يبرر

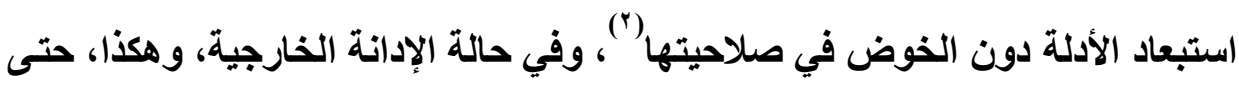
لو أن مثل هذه الثهادة ليست مؤشرًا على سلوك يمثل جريمة بموجب القانون الجنـائي الأمريكي، الإدانـة الخارجيـة، فـي معظم الحسالات، سـوف تـوفر أدلـة دون أن تسبب المشاكل التي ترتبط عادة مع مثل هذه الأدلة. وإذا كان يمكن استبعاد إدانة خارجية تقوم على أسس موضوعية غير معتادة على أساس أسباب ذات أهمية وصلة بالموضوع، فالإدانـة في جريمـة أجنبية ربمـالن

(1) FED. R. EVID. 608, 609.

(2) 3A J. WIGMORE, EVIDENCE IN TRIALS AT COMMON LAW ?? 979-980 (rev. ed. J. Chad- bourn ed. 1970). 
يكون مفيلًا في إثبات الحالة العقلية بشأن القصد، الدافع أو العلم. وعلاوة على ذلك، فإن العديد من قوانين العود لها منطلبات محددة بشأن ما يشكل منطلبات الإدانة المسبقة

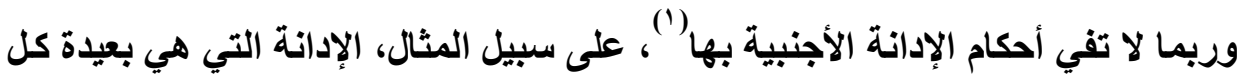
البعد عن القـانون الأمريكي، مثلمـا هو الحسال في جريمـة "الكفر " بموجب الشريعة الإسلامية، ومثل هذه الإدانـة قد تكون ذات صلة في استبعاد أحد الشهود إذا تضمنت

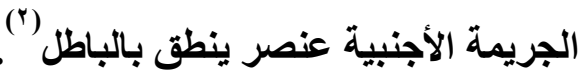

الاستخدام الفرعي للإدانات الأجنبية التي تبتعد كثيرًا عن المعايير الأمريكية،

يمكن أيضًا أن يثير مخـاوف حول نزاهة المحاكم، كما سبق الإثـارة، فالاعتمـاد على الإدانـات غير الاستورية بالنسبة للجرائم في الولايـات القضائية أمريكية يثير نفس المخاوف بثأن سلامة ونزاهة العملية القضائية، التي من سلطتها زيادة الاعتمـاد على العى الإدانـات التي تم الحصول عليها في إطـار إجراءات مخالفة للمعايير الأمريكية. على

(1) Although it is a matter of statutory interpretation, Annot., 19 A.L.R.2d 227, 233 (1951), the overwhelming majority of jurisdictions with recidivist statutes require that the prior conviction be based on facts that would constitute a felony under their laws. e.g., People v. Dabney, 250 Cal. App. 2d 933, 948, 59 Cal. Rptr. 243, 253 (1967), cert. denied, 390 U.S. 911 (1968); People v. McIntire, 7 Mich. App. 133, 140, 151 N.W.2d 187, 191 (1967); People ex rel. Bell v. Martin, 283 A.D. 1005, 1005, 131 N.Y.S.2d 1, 2 (1954) (mem

(2) Cf. State v. Prince, 64 Idaho 343, 350, 132 P.2d 146, 149 (1942) (allowing use of Oregon conviction for purposes of an Idaho "persistent violator" statute without proof that underly- ing offense was an Idaho felony because "[glood citizenship requires obedience and observ- ance to the laws of sister states as much as those of this state 
سبيل المثال، يمكن أن يطلب من المحكمة قبول أدلة الإدانـة "سوفيتية" لممارسـة مـا، تعتبر بالنسبة للولايات المتحدة داخلة ضمن حق التعديل الأول، لأن استخدام مثل هذه الإدانـة مـن شـأنه أن يرفع خطر الاعتقـاد بـأن المحـاكم الأمريكيـة تتغاضسى عن القــع .

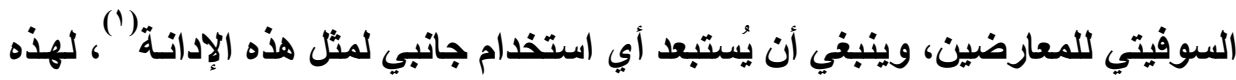
الأسباب، ينبغي أن تكون المحاكم حذرة للغاية من الاعتر اف بالإدانـات الخارجية عندما يكون السلوك الأساسي الأجنبي مُجرم بالكامل ومُعاقب عليه، دستوريًا أو وفقَا للقانون الأمريكي.

ومع ذلك لا يزال هناك حلاً وسطَا بالنسبة للجرائم التي تكتنف الإدانات الأجنبية

والتي تثير الإثكالية مـع الصواب والخطأ الأمريكي، والمثال على ذلك، هو الأنظمـة

الأجنبية التي تعاقب شخص لفثله في تقديم المساعدة لشخص غريب في أمس الحاجة إليها (") و وعلى الرغم من أن هذا الفعل عادة يكون خـارج نطاق المسؤولية التقصيرية

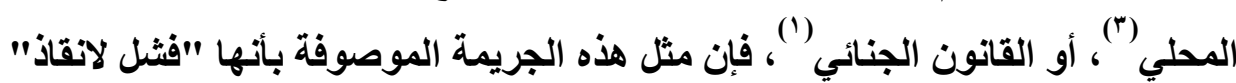

(1) It should be noted that the statement in the text applies only to the introduction of the prior conviction. The underlying facts might still be admissible, if relevant, under certain circumstances. Under the Federal Rules of Evidence, for example, the principle would pre- clude use of the conviction for impeachment purposes under Rules 608(b) and 609, but would not bar introduction of the underlying facts under Rule 404(b).

(2) Feldbrugge, Good and Bad Samaritans: A Comparative Survey of Crim- inal Law Provisions Concerning Failure to Rescue, 14 AM. J. COMP. L. 630 (1966).

(3) W. PROSSER, HANDBOOK OF THE LAW OF TORTS ? 56, at 34043 (4th ed. 1971). 
تتفق مع أفكارنـا وتهذيبنا الأخلاقي، وعلى افتراض أن الشخص لاحظوجود جريمـة أو علم بأن هذا الفعل مجرم بموجب قانون أجنبي، أو ذو صلة بسلوك مُجرم وطني، فعندما تُعرض مثثل هذه الإدانـة أمسام محكمـة أميركية يجب أن يـتم النظر في مـدى ملاعمتهـا للإدانة في ضوع معايير متباينة من السلوك. ونلاحظ أن الإدانـات الخارجية لمثل هذه الجرائم مختلفـة قليلا وليس مسن المتوقع رفع نفس المخــاوف بشـأن سـلامة النظـام

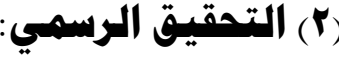

كد أدنى، الإدانة الأجنبية يمكن أن تعتبر مصدر ثقة فقط إذا تم التوصل إليها

بعد أن عقد لجنة تحقيق رسمية فيها ومتابعتها. ويُعد هذا شرطا مهمًا لأن الاستماع إليها ومناقشتها في جلسات غير رسمية قد لا توفر أساسا كافيا لتقييم مشروعية الإدانة الأجنبية، والأهم من ذلك، أن إجراء تحقيق رسمي هو أفضل ضمان للتثبت مـن أن الإدانة نتجت عن دراسة متأنية، وبدون مثل هذا التحقيق، قد لا يكون عند المتهم فرصة لتقديم الدفاع والحصول على فحص نزيه، أو عناصر أسناسية لنتائج موثوقة (").

(1) Feldbrugge, supra note 65, at 652-5

(2) One could argue that if the foreign law imposes a standard of conduct with which the American abroad would be unfamiliar, use of such a conviction might raise notice and vague- ness problems. There is no reason to think, however, that ignorance of the law should consti- tute grounds for exclusion of the foreign conviction in a collateral proceeding when such a reason is generally not a recognized excuse in an ordinary American proceeding

(3) While one might at first assume that a secret proceeding might be per se unreliable, the truth of the generalization depends on what one means by $=$ 


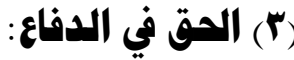

في المحسكم الوطنيـة، التعديل السادس (') يضمن للمتهم الحق في مواجهة

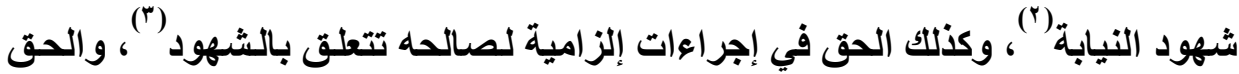

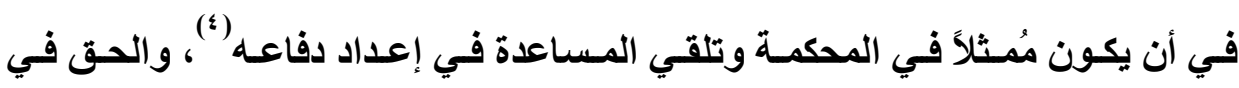

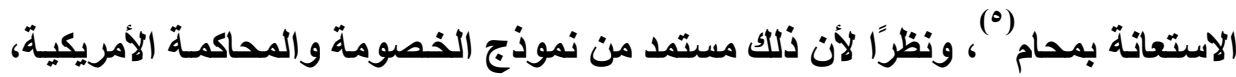
فإن بعض هذه الحقوق قد لا تكون ذات صلة بحكم الإدانـة الأجنبي، على سبيل المثال، أهمية فرصة مواجهة الشهود التي قد تؤثر بثكل جوهري على موقف المتهم، ولكنها تكون أقل أهمية في بعض الأنظمة القانونية حيث يكون قاضي المحكمة هو رئيس الطب

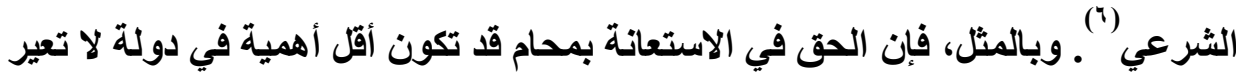

"secret." On one hand, a proceeding closed to the public but in which a trial record is preserved for appellate review would seem to be reliable. Cf. Gannett Co. v. DePasquale, 99 S. Ct. 2898 (1979) (public may be excluded from pretrial suppression hearing). If, however, the trial is closed from public view, no transcript is kept, and appellate review is unavailable, admissibility on both reliabil- ity and judicial-integrity grounds is seriously in question

(1) U.S. CONST. amend. VI.

(2) Pointer v. Texas, 380 U.S. 400 (1965).

(3) Washington v. Texas, 388 U.S. 14 (1967).

(4) Illinois v. Allen, 397 U.S. 337, 338 (1970).

(5) Gideon v. Wainwright, 372 U.S. 335 (1963).

(6) In a pure inquisitorial system, the presiding officer conducts all aspects of the trial and no counsel is present. See J. LANGBEIN, PROSECUTING CRIME IN THE RENAISSANCE: ENGLAND, GERMANY, FRANCE 110 n.28 (1974); Langbein, The Criminal Trial $=$ 
هذا الإجراء أهمية قصوى، أو عندما تكون حماية الحقوق الإجرائية للمدعى عليه هي

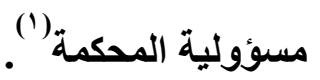

الضمانات الخاصـة التي ينص عليها الاستور الأميركي، سـواء ذات الصلة

بأنظمة الخصومة القانونية أم لا، في نهاية المطاف تمنح المتهم الحق في تقديم دفاع؛ للرد بشكل فعال على الأدلة المقدمة ضده، وسماع قناعته الخاصـة بالحقائق، والقلسفة الكامنة في ذلك تتجسد في أن حقوق المواجهة واستماع آراء المتهم هي الأكثر تأثيرًا واحتمالا لتطوير أفضل دليل لصالح المتهم، وأنه غالبًا ما يكون مطلعًا على أكبر قدر من

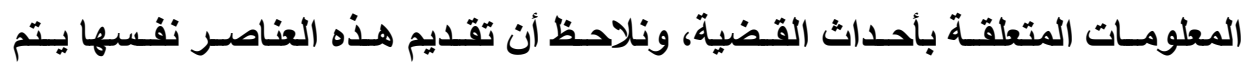
بإجراءات مختلفة تمامًا في سياق الأحكام الأجنبية: نظام التحقيق الشفاف، على سبيل المثال، مسؤولية جمـع المعلومـات هـي مهمـة تقع على عـاتق القاضـي الذي يترأس الجلسة، وليس الأطراف، وقد يحل محل المواجهة فرصـة استدعاء شـهود المحكمـة

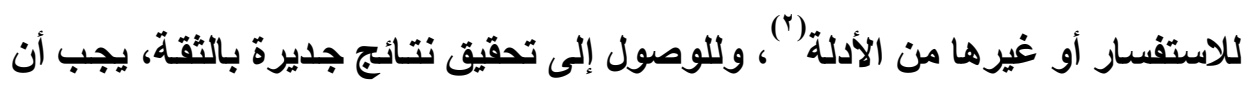
تتبع المحاكم الأجنبية إجراعات تقديم ضمانات تفيد بـأن المتهم هو مـن أورد مـا يعرفه

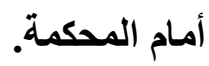

before the Lawyers, 45 U. CHI. L. REV. 263, 282 (1978) (discussing the Old Bailey). This form of procedure lives on in American jurisprudence in the summary court-martial. See U.S. DEP'T OF DEFENSE, MANUAL FOR COURTS-MARTIAL, UNITED STATES 14-1, 14-2 (rev. ed. 1969).

(1) See text and notes at notes 97-100 infra

(2) J. LANGBEIN, COMPARATIVE CRIMINAL PROCEDURE: GERMANY, supra note 75, at 90; Strafprozessordnung [STPO] ?? 160, 161a (1978) (W. Ger. Code of Crim. Pro 


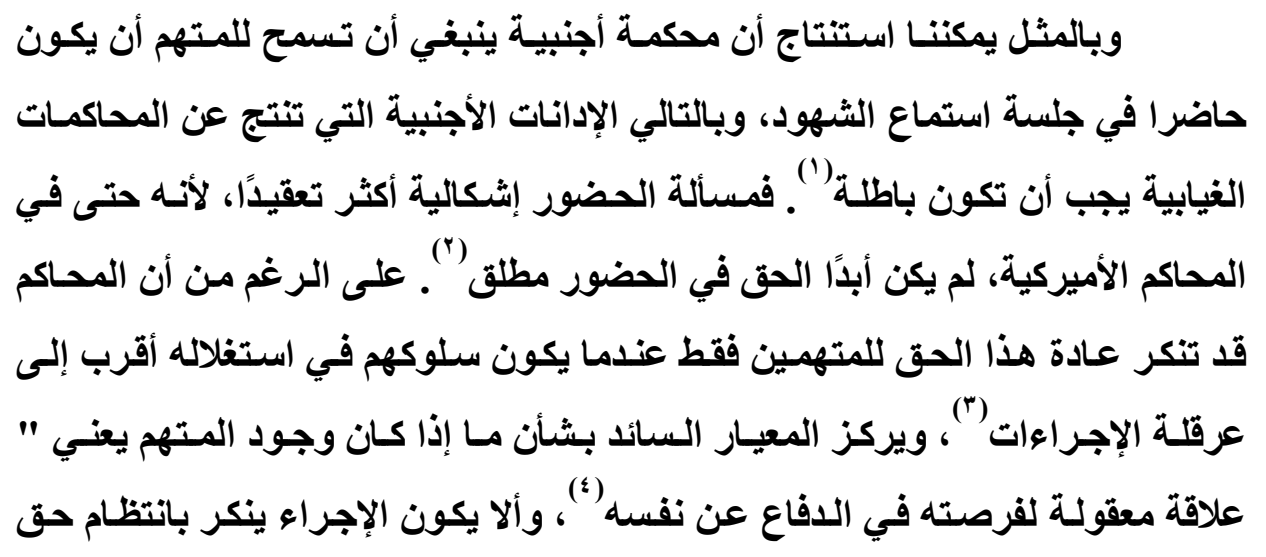

(1) But see Gallina v. Fraser, 278 F.2d 77 (2d Cir.), cert. denied, 364 U.S. 851 (1960). The Second Circuit allowed extradition to Italy of a defendant convicted twice in absentia there, finding that the proceedings were not "antipathetic to a federal court's sense of decency," id. at 79. The court found that the defendant had been represented by counsel at one of his trials in absentia, and that his cohorts were present as his codefendants at the other

(2) Annot., 25 L. Ed. $2 d 931$ (1971).

(3) Illinois v. Allen, 397 U.S. 337 (1970). Other reasons for exclusion have included a determination that the accused's presence serves no purpose, e.g., Hayton v. Egeler, 405 F. Supp. 1133, 1150-51 (E.D. Mich. 1975), aff'd, 555 F.2d 599 (6th Cir.), cert. denied, 434 U.S. 973 (1977); United States ex re[ Spinney v. Fay, 228 F. Supp. 500, 501 (S.D.N.Y. 1964) (quoting Snyder v. Massachusetts, 291 U.S. 97, 106-07 (1934)), or a finding that the accused has fled the jurisdiction, see Taylor v. United States, 414 U.S. 17 (1973)

(4) Synder v. Massachusetts, 291 U.S. 97, 106 (1934). 
المتهم في الوصول إلى إجراعات معينة، أو ينفي حق المتهم في الحصول على ممثل، أما الحضور في كل الأحوال فهو أمر افتراضي أكثر منه واقعي.

مشكلة اللغة تُضيف بعدًا آخر لهذه القضايا، حتى إذا كـان المتهم حاضرًا فعليًا

في محاكمته، ولكنه لا يفهم لغة البلد المضيف، فإن هذا من شـأنه، في حال عدم وجود مترجم، أن ينتقص مـن الحكم في كثير مسن النـواحي (')، مـن حيث عدم فهـم المتهم للإجراءات، وعدم قدرته على فهم الدفاع عن نفسه. ومع ذلك، مثل هذا المدعى عليه، إذا قام محام بتمثيله؛ فلن يعلم المتهم بتفاصيل القضية إلا بنهايـة الإجراعات كل يوم، وبالتـالي لن يستطيع الاشتراك مـع محاميه في التحضير للمحاكمة، ومن المثالب في المحاكم الأميركية، أنها عندما تواجه مشكلة المتهم الذي لا يفهم اللغة الإنجليزيـة، قد تقـرر أن الترجمـة الفوريـة ليست ضـرورية طالمــا يوجـــ محسامي يمكنـه متابعـة

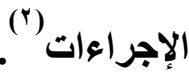

(1) United States ex rel. Negron v. New York, 434 F.2d 386, 389 (2d Cir. 1970); United States ex rel. Navarro v. Johnson, 365 F. Supp. 676, 681 n.3 (E.D. Pa. 1973).

(2) Annot., 36 A.L.R.3d 276 (1971); Annot., 140 A.L.R. 766 (1942). Counsel is guaran- teed, but there is no constitutional right to the presence of an interpreter. The right of confrontation inherent in due process may at times necessitate the presence of an interpreter. See, e.g., United States ex rel. Navarro v. Johnson, 365 F. Supp. 676, 681 (E.D. Pa. 1973); Markiewicz v. State, 109 Neb. 514, 520-21, 191 N.W. 648, 650-51 (1922); Garcia v. State, 151 Tex. Crim. 593, 602, 210 S.W.2d 574, 580 (1948); State v. Vasquez, 101 Utah 444, 449-52, 121 P.2d 903, 905-06 (1942). But if the defendant has some grasp of English and comprehends the substance of the trial, no interpretation is necessary. See, e.g., United $=$ 
وتششير هذه الاعتبـارات أن حل قضايا الحضور مـرتبط في النهايـة بتـوفير

محامين محليين، ومـع ذلك، ينبغي أن ألا يعتبر غياب المحامي أثـاء المحاكمـة دائمًا حاسمًا في تحديد مشروعية الإدانة. على سبيل المثال، حيث تتيح ولايـة قضائية أجنبية المـتهم بالمـشـاركة في محاكمتهـ، والمـتهم يفهـم اللفـة المحليـة، وإجـراعات المحكمـة واضحة وعلمت بسهولة، عدم وجود محامي قد لا تنال من مصداقية الاقتناع.

أيضًا الـصلة بـين مـا إذا كـان غيـاب المحسامي يجب أن يحول دون اسـتخدام

ضمانات الإدانة الأجنبية هو نوع من النظام القانوني في دول أجنبية، وعلى الرغم من أن المحكمة العليا قد أثـارت إلى أنها في نظسم الخصومة يعتبر حضور المحامي أمر ضروري للحصول على نتائج موثوقة' '، فبإن أي استتناج مماثل يمكن تقريره لنظام التحقيق الثفاف، الذي فيه الدفاع أو الادعاء، لا يزال قائمًَا، و يفترض القاضسي مهام القاضي أو المدعي العام، والمدافع (†)

ومن الناحية العملية، من المرجح أن أي صعوبات لغوية أو فنية محلية سوف

تكون كبيرة بما يكفي لتجعل الإجراءات المتخذة مـع غياب المحامي لا يمكن الاعتمـاد عليها، أما نظام التحقيق الشفاف هو أقل شيوعًا من النظام المختلط المتبع الآن في

States v. De Leon, 498 F.2d 1327, 1333 (7th Cir. 1974); Flores v. State, 509 S.W.2d 580, 581 (Tex. Crim. App. 1974); Diaz v. State, 491 S.W.2d 166 (Tex. Crim. App. 1973); State v. Karumai, 101 Utah 592, 126 P.2d 1047 (1942). The government is not bound to provide simultaneous translation.

(1) Gideon v. Wainwright, 372 U.S. 335 (1963).

(2) authorities cited note 75 supra

مجلت البحوث القانونيت والإقتصاديت 
معظم دول القارة' ') وفي مثل هذا النظام، القاضسي يسيطر في النهايـة على البحث في المعطيات، ولكن محامي المدعي العام والدفاع يلعب دورا مهمًا في تفسير المعلومـات التي استقاها من قبل القاضي ". وتثير هذه الاعتبارات في تقييم استخدام ضمانات من

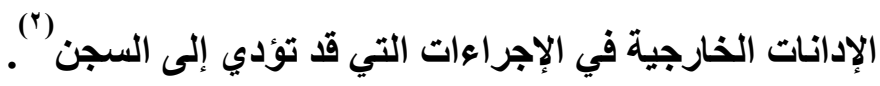
خامساً: همكمة همايدة: ضمانتات المشروعية المتطلبـة في جلسات الاستماع الرسمية، وتقديم دفاع إثبات، قد تعتبر في نهايـة المطاف أمور جوفاء، إذا كانت مداولات المحكمة الأجنبية ليست محايدة، ومن الصعوبة بمكان تحديد أدلة معينة تشير إلى الحياد في أي محاكمة تؤدي إلـى إدانـة أجنبيـة، خاصـة وأن المحكمـة المحليـة ليست في وضـع يمكنهـا مـن التحقيق في الحالـة الذهنيـة للمحاكمـة الخارجيـة. ولكن هنـاك دلائل يمكن مـن خلالهـا التعرف على ذلك مثل: جديـة وانتظام الإجراءات القضائية في الدولة صساحبة الحكم، ومعرفة أن الدولة عمومًا تُعرف بحفظ كرامة مواطنيها ومن ذلك المحاكمات.

(1) Damaska, Evidentiary Barriers to Conviction and Two Models of Crimi- nal Procedure: A Comparative Study, 121 U. PA. L. REV. 506, 555-60 (1973)

(2) 13 If imprisonment is not threatened, the potential damage to the defendant through collateral use of the foreign conviction is less, although the reliability of the conviction is still suspect. Consequently, the hesitancy to exclude should not be as great. Cf. Scott v. Illinois, 440 U.S. 367 (1979) (counsel not constitutionally required if defendant not im-prisoned).

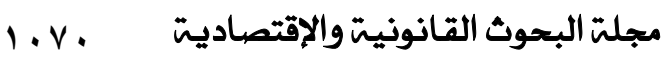


وينبغي أن تكون المحاكم المحلية حساسة لوجود دليل على التحيز العـام في

البلا المضيف، فقد ترى المحاكم الأمريكية أن أحكام الإدانـة الأجنبية قد يكون الهـف منها عداء على أسس عرقية أو دينية ، أو حتى سياسية، وتواجـه المحاكم الأمريكية بعض الخبرة في هذا النوع من المشاكل في القضايا المحلية ولايها القدرة على التعرف على مثل هذه العداوة عند نشوئها في المحاكم الأجنبية. وتجدر الإثـارة إلى أنسه، مع ذلك، في المحاكم المحلية يقتصر فحص المحلفين لهذه المسائل مع اعتبار أنه لن يفسد قناعتهم على أساس الوقائع المعروضة، وبطبيعة الحال، فإن أي تحيز قضائي في شكل مصلحة مالية نتيجة المحاكمة يؤدي أيضًا إلى استبعاد الإدانات الناتجة عن ذلك المنحى

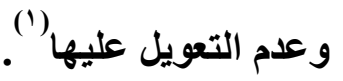
ويمكنتا القول بأن الدور الذي يلعبـه القاضـي في نظام التحقيق الشفاف، هو

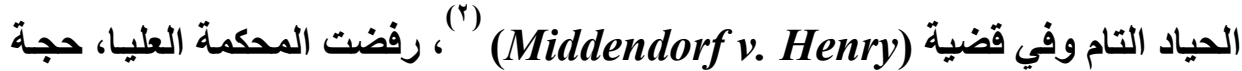
مماثلـة في سياق عسكري، ورأت أنـهـ يجب التأكد من دقة ونزاهـة عمليـة المحاكمـة، والتأكد من صيانة حقوق الدولة والمتهمين على حد سواء، تحليل مماثل عند تقيبم أنظمة تحقيق أخرى، شريطة أن يكون القاضي تحت التزام مماثل، ويؤدي عمله بـون انحياز.

(1) Tumey v. Ohio, 273 U.s. 510 (1927); cases collected in Annot., 72 A.L.R.3d 375 (1976)

(2) Schmidt, Introduction to THE GERMAN CODE OF CRIMINAL PROCEDURE at 2 (H. Niebler \& M. Pfeiffer trans. 1965); G. WILLIAMS, THE PROOF OF GUILT 30 (2d ed. 1958 


\section{اختبار الإدانات الأجنبية}

\section{أولاً: الصعوبات العملية والسياسية:}

توفر الإجراعات الأجنبية ضمانات كافية من المشروعية هي في المقام الأول

ممارسة النظرية على أساس فحص مستنير للأحكام الجنائية الأجنبية ودور الإجراءات المحددة داخلها. ولذلك، فـإن إجراء تقيـيم مناسب للإدانـة الأجنبيـة يمكن أن تـتم في

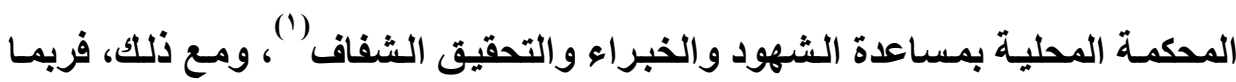
تكون الأدلة المتاحة للمحمة الأمريكية غير كافية لتحديد مشروعية للإدانة من خلال الإجراعات الأجنبية.

وقد تكون مثل هذه المشكلات اللوجستية أكثر تـأثيرًا عند تقيـيم مشروعية

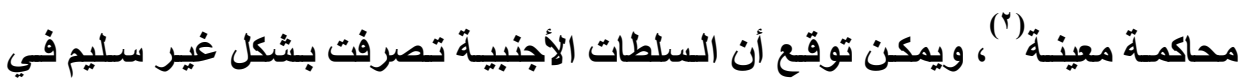

(1) The literature in comparative law on protection of the accused's rights under foreign criminal justice systems is extensive. See, e.g., THE ACCUSED: A COMPARATIVE STUDY (J. Coutts ed. 1966); G. MUELLER \& F. LE POOLE-GRIFFITHS, COMPARATIVE CRIMINAL PROCEDURE (1969); 37 REVUE INTERNATIONALE DE DROIT PtNAL 5-318 (1966) (series of articles dealing with rights of the accused in various countries). For the particular techniques used to prove foreign law, see, for example, 0. SOMMEREIGH \& B. BUSCH, FOREIGN LAW: A GUIDE TO PLEADING AND PROOF (1959); McKenzie \& Sarabia, The Pleading and Proof of Alien Law, 30 TUL. L. REV. 353 (1956); Nussbaum, The Problem of Proving Foreign Law, 50 YALE L.J. 1018 (1941).

(1) For example, apart from considerations of distance and expense, the stenographic trial transcript that an American appeals court would $=$ 
الحصول على إدانـات، وذلك من خـلال استتعراض إجراءات القانون الجنـائي الأجنبي وبيان أنه ربما يكون غير جدير بالثقة في المحسكم الأمريكية، وعادةً، لا يمكن التحقق من مثل هذه الادعاءات أو دحضها دون أدلة متوفرة في الاولة المضيفة. إن رفض التحديات الروتينيـة التي تواجـه إجراعات جنائية معينة تميل إلى . التقليل من شـأن تحليل الإجراعات القانونية، يضع عبئًا كبيرًا على المدعى عليه في إثبات أن إدانة مسبقة معينة غير جديرة بالثقة، وهو مـا يتـافي مـع الحماية ذاتها التي يمنحها حكم قضية "Burgett" وكذلك "الاستور". بالإضافة إلى المشكلات العملية التي تواجه مراجعة المشروعية، فمن المرجح أن تنشأ صعوبات سياسية، فلا يمكن توقع أن تبالي دول أجنبية بشأن مـا تصدره من أحكام، لأنه قـ يُعرض على محكمة أميركية وتدقق فيـه كقناعة أجنبية محاكمها، بل إن قضاء الدول إذا طلب منه وضع مثل هذه المسألة في الاعتبار فإن ذلك يمثل إهانة لنظام العدالة الجنائية، وقضاتها، والتشكيك في إجراءاتها، ونظام عملها، وتعقب كيفية تكوين الإدانـة مـن الاستجواب والتحقيق ممـا قد يخلق استياءً كبيرًا في هذا المجـال وقد لا

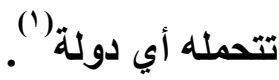

regard as essential for review, see Holmes v. Laird, 459 F.2d 1211, 1214 (D.C. Cir.) (dictum), cert. denied, 409 U.S. 869 (1972), is not ordinarily available in German criminal proceedings, J. LANGBEIN, COMPARATIVE CRIMINAL PROCEDURE: GERMAN

(1) Oetjen v. Central Leather Co., 246 U.S. 297, 304 (1918) ; Note, Discovery of Documents Located Abroad in U.S. Antitrust Litigation: Recent Developments in the Law Concerning the Foreign Illegality Excuse for Non-Production, 14 VA. J. INT'L L. 747, 748 (1974). 
هذه المخاوف السياسية قد ترتفع لمستوى المشكلات الاستورية، فالتحقيقات

المتكررة من قبل الدولة والمحاكم الاتحاديـة في الإجراعات الجنائية لدولة أجنبيـة قد

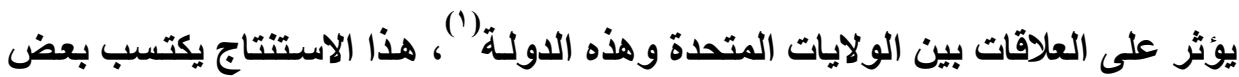

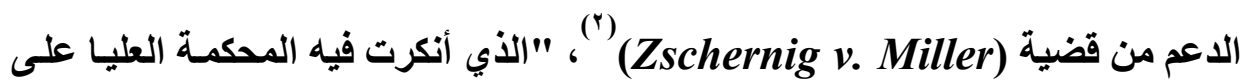
قانون ولاية أوريجون أنه يحظر الإرث لمن لا يحيا داخل الولايات المتحدة مـا لم يتمكن من إثبات، في جملة أمور، أن الدول التي يعيشون فيها لن تصادر مثل هذه الممتلكات، ولاحظت المحكمـة أن النظـام الأسـاسـي "يؤُثر في العلاقـات الدوليـة بطريقـة مستمرة

(1) The doctrine requires courts to "refrain from examining the validity of an act of a foreign state by which that state has exercised its jurisdiction to give effect to its public interests." RESTATEMENT (SECOND) OF FOREIGN RELATIONS LAW OF THE UNITED STATES ? 41 (1965). As a rule of law, the doctrine would not prohibit collateral examination of foreign convictions since the "reliability" of the judgment, rather than its "validity," is being exam-ined: a court's disapproval would have no effect on the policies of the foreign country. Fur-thermore, the doctrine principally relates to choice of law and "is applied only in cases in which ... the settlement of a claim or interest involv[es] the same transaction as that involved in . . . the [foreign] exercise of jurisdiction," id. ? 41, Comment $\mathbf{j}$. As a statement of policy or principle, however, the doctrine does have some significance. "The policy underlying the doctrine is that the courts should abstain from any action that might hinder the executive branch in the conduct of foreign relations." Id. ? 41, Comment c. The necessity of courts to pry into and pass judgment on foreign adjudications may lead to political repercussions that would hinder development of foreign relations.

(2) 389 U.S. 429 (1968). 
وخفية، " لأنه أنشأ "(نتقادات قضائية" لا مفر منها للاول التي تمسارس سلطتها بشكل أكثر تعسفًا (')

\section{ثانياً: اقتراح لفهص الإدانة الأجنبية:}

لتصميم نظام دقيق في حالات استخدام الإدانـات الأجنبية، يجب أن يستوعب

مصالح مختلف الأطراف، في البدايـة، يجب على الدولة أن تخطر المدعى عليه عن نيتها استخدام الإدانة الأجنبية، وإذا تضمنت القناعة الأجنبية معلومات غير جلية ينبغي التحقق منهـا في وقـت مبكر مـن المحاكمـة، ويجب أن تكون الأدلـة مؤيـدة بوسـائل مشروعة للإثبات (؟)، وكذلك الضمانات الإجرائية العامة، والتحقيق في حيثيات الإدانة، وأن يكون لاى المدعى عليه مكنة تحديد العيوب في الإجراءات الجنائية التي أدت إلى إدانته في الخارج. هذه الادعاءات، التي قد تركز إمـا على طرق الحصول على الإدانـة الأجنبية وأنها غير كافية في ظل الأنظمة المتقدمة، أو أن هذه الإدانة كاتت على أسساس عرقي أو سياسـي أو غيرهـا مـن وسـائل التمييز والتي هـي كفيلـة بتحريك الضمير الإنساني.

(1) 389 U.S. 440 (1968).

(2) The Court in Burgett v. Texas, 389 U.S. 109 (1967), did not assign the ultimate burden of proof for cases involving the use of allegedly insufficient prior convictions. At least one court has noted the continuing silence of the Supreme Court, the Federal Rules of Evidence, and the Uniform Rules of Evidence on the burden of proof in disputes over the collateral use of prior in-state convictions. Reinsch v. Quines, 274 Ore. 97, 104 n.5, 546 P.2d 135, 139 n.5 (1976). 
هذا الإجراء يتيح للمدعى عليه أن يبرأ نفسه من خلال استبعاد إدانـة لا يمكن

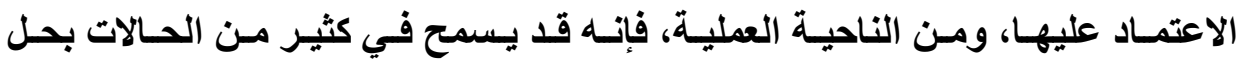
مبكر للقضية، فعندما تعترِي الشبهات أي إدانـة أجنبيـة فبإن الدولـة لن تهـدر الوقت والموارد للدعم مثل هذه الإدانـة، وبمـا يضمن اقتصار التحقيقـات الخارجيـة فقط على

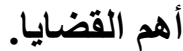

\section{أهم التوصيات}

- تنظيم مكتب دولي للوثائق التشريعية وأحكام القضاء في المواد لجنائية، لمختلف دول العـالم ، بـل أن الجمعية الدوليـة للقـانون الجنـائي بإمكانهـا أن تطلب من أب منظمة دولية القيام بذلك الاور كالمنظمة الدولية لليونسكو. - ضرورة التوسع في اللجوء إلي المحكمة الجنائية الدولية للنظر في مدي تطبيق القانون الأجنبي، لحسم المشاكل الناتجة عن تـازع الاختصاص. ويمكن أن تنص الدول على تطبيق القوانين الجنائية الأجنيـة في قوانينها الوطنية، على منوال قواعد التنازع، ولا يجب إثارة الجدل من جديد عن توحيد موادها. - وجوب تطبيق المحساكم الوطنيـة على مختلف درجاتها للقانون الجنـائي الأجنبي المختص، أسوة بما هو متبع في تطبيق القوانين الأجنبية غير العقابية. - نرى ضرورة الإسراع في توحيد العقوبات المتناظرة في جميع الدول، لتوضع في قائمة واحدة معلنة للجميع، على أن تلرس في مختلف المعاهد القانونية. - يمكن - في اعتقاديـ السماح للقاضي الجنائي بالرجوع للقانون الجنائي الأجنبي، للحكم في الدعوى الجنائية المعروضة أمامسه، حتى ولهو أدي ذلك إلى تطبيق هذا القانون، طالما كان ذلك أفضل لحسن سبر العدالة، مـع التظلب على فكرة تنازع 
السيادات التي تحساول دول كثيرة التمسك بها، وذلك عن طريق عقد الاتفاقيات الاولية، والنص عليه في القوانين الداخلية.

- لا يجب التذرع بفكرة النظام العام الداخلي لاستبعاد تطبيق القوانين الأجنبية التي تصون - في حقيقة الأمـر - النظـام العـام اللدولي التي قررت في حقيقة الأمـر لحماية الأفراد وضمان حقوقهم، بغض النظر عن جنسياتهم أو قوانينهم، فالعدالة أسمي من كل اعتبار.

- في خصوص المحررات الأجنبية يجب الرجوع إلى قانون الدولة الأجنبية لمعرفة مـا يعد محرر رسـي من عدمـه ، علـي أن يرجع القاضسي عند الفصل في تـوافر أركان جريمة تزوير المحرر إلي قانون العقزبات الوطني لا الأجنبي. - يكون للحكم الأجنبي قوة الثيء المقضي به في جميع الحالات التي يكون للاولة فيها اختصاص تبعي، وعلى الأقل يجب أن يخصم من العقوبـات التي يقضي بها العقوبة التي نفذت في الخارج. - لا يجوز تنفيـذ الحكم إذا كـان قد سقط بالتقــادم أو العفـو في أي الدولتين، التـي أصدرته أو يزمع تنفيذه فيها. ويجب أن يكون ممكنا أن يستبدل بالعقوبـة المحكوم بها عقوبة أخرى ينص عليها قانون الدولة المنفذة لنفس الجريمة على ألا يكون في ذلك تثديد على المحكوم عليه. - بالنسبة للأحكام التي تتطلب مراقبة سلوك المحكوم عليه، كوقف تنفيذ العقوبـة، والوضع تحت الاختبار، والإفراج الشرطي وغيرهـا، يجب أن يكون في الإمكان تنفيذها في دولة أخرى كدولة محل الإقامة، وتصدر أحكام الموضوع عند مخالفة الثروط المفروضة على المحكوم عليه من قضاء الدولة التي أصدرت الحكم أو 
التي يجري فيها التنفيذ، ويفضل القضاء الأخير تبسيطاً للإجراءات.

- نوصي بقر الإمكان تشبيه الأحكام الأجنبية بالأحكام الوطنيـة فيمـا يتعلق بتطبيق أحكام العود وتعدد الجرائم والإفراج تحت شرطو غيرها من النظم التي يعرفها كل

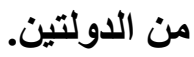
- فيما يتعلق بإجراءات الاعتراف بالحكم الأجنبي، نوصي بترك حرية تقرير الموقف لكل دولة عبر صورة دعوى تنفيذ أو بطريق أبسط. فلا يكون التثبت من صحة الحكم إلا من الناحية الإجرائية دون النظر في الموضوع. 